\title{
BIG IDEAS IN LITTLE BOXES: NATION BUILDING IN THREE NINETEENTH-CENTURY AMERICAN PARLOR GAMES BY MILTON BRADLEY \& COMPANY
}

\author{
A dissertation presented to \\ the Faculty of the Graduate School \\ at the University of Missouri-Columbia \\ In Partial Fulfillment \\ Of the Requirements for the Degree \\ Doctor of Philosophy \\ by \\ MARGARET FAIRGRIEVE MILANICK \\ Dr. Kristin Schwain, Dissertation Advisor \\ MAY 2020
}


(C) Copyright by Margaret Fairgrieve Milanick 2020

\author{
All Rights Reserved
}


The undersigned, appointed by the dean of the Graduate School, have examined the dissertation entitled

\section{BIG IDEAS IN LITTLE BOXES: NATION BUILDING IN THREE NINETEENTH-CENTURY AMERICAN PARLOR GAMES BY MILTON BRADLEY \& COMPANY}

presented by Margaret Fairgrieve Milanick

a candidate for the degree of Doctor of Philosophy, and hereby certify that, in their opinion, it is worthy of acceptance.

Professor Kristin Schwain

Professor Ilyana Karthas

Professor Michael Yonan

Professor James Van Dyke 


\section{DEDICATION}

To my husband, Mark Milanick, and to my son, William Milanick, my love and gratitude for their support through every step of the long and winding journey to achieve my PhD. Without their support I could have never even started. And to all my friends who cheered me on at all the milestones on the way. 


\section{ACKNOWLEDGEMENTS}

First and foremost, I wish to extend my heartfelt thanks and gratitude for the support of my dissertation advisor, Dr. Kristin Schwain. She is a gifted scholar, mentor and teacher. I thank her for her expert insights, knowledge, and ability to give direction just when I needed it. Because of her expert teaching and guidance, my journey through the academic program was made so much more fruitful, exposed me to so many new ideas, gave me the opportunities to participate in innovative projects, and allowed me to develop as a scholar with an inquisitive mind. For that, I am, and will be forever, grateful.

I took two dynamic courses from my outside reader, Dr. Ilyana Karthas, a teacher and scholar extraordinaire in the History

Department. Her teaching opened doors to productive ways to analyze gender, nation building, the way history is written, and the ways economic systems change structures of societies, that proved crucial to developing my thinking about the objects and time period I chose to study. She was always an enthusiastic listener, advisor and supporter of my work. I thank her for her insights, her expert teaching, and her support. 
I thank Dr. James Van Dyke for his work and support on my committee, and his enthusiasm for the progress of my research and writing. And an added thank you to him for giving me the title for my dissertation "Big Ideas in a Little Box." I thank Dr. Michael Yonan, who as my Master's thesis advisor helped prepare me for the rigors of working on a dissertation.

I am grateful to the many archivists and librarians that helped me procure and access materials I needed for my research. Special thanks to Rachel Jirka of the Society of Cincinnati in Washington, D.C. for scanning and sending me the script for the Historiscope. I wish also to pay special thanks to the librarians at Beinecke Rare Book and Manuscript Library in New Haven, Connecticut for sending the digitized images for both the Myriopticon and Historiscope, and the script for the Myriopticon, and to the librarians at the Library of Congress who answered my questions even during a government shutdown. Thank you also to all the librarians in Special Collections at Ellis Library at the University of Missouri who helped me find so many of the primary sources I needed.

Last but not least, I want to thank neighbors and friends, Brian and Susan Smith, for their encouragement and enthusiasm for my 
academic endeavors that extended even so far as agreeing multiple times to join my husband and me to play the parlor games that I was researching. 


\section{TABLE OF CONTENTS}

ACKNOWLEDGEMENTS ...............................................................................

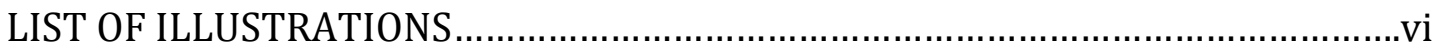

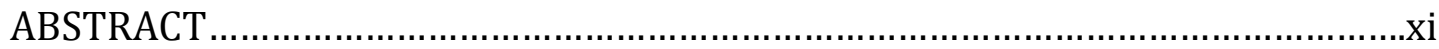

Chapter 1. Introduction .............................................................................. 1

Chapter 2. The Checkered Game of Life...............................................................24

Chapter 3. The Myriopticon, A Historical Panorama of the Rebellion..................62

Chapter 4. The Historiscope, A Panorama and History of America......................88

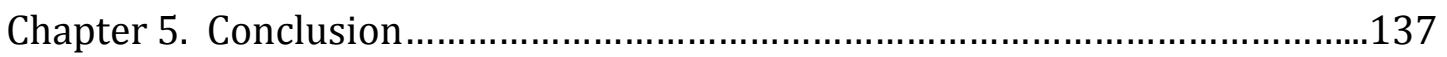

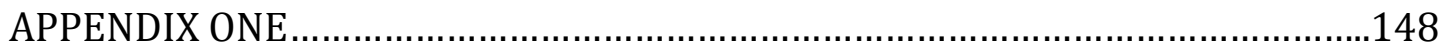

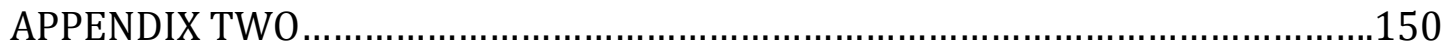

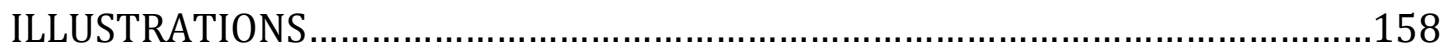

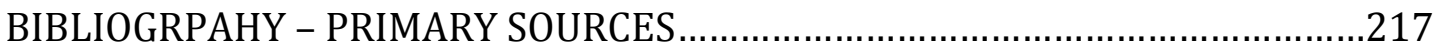

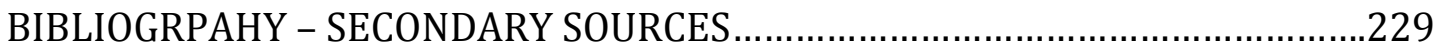

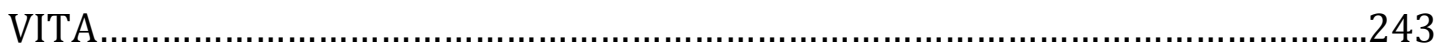




\section{LIST OF ILLUSTRATIONS}

Figure

1.1 “Check-Mate!” Harper's Weekly IX, no. 440 (June 3, 1865): 337. Wood engraving.

1.2 Milton Bradley \& Company, The Checkered Game of Life, 1860. Pasteboard, paper and chromolithography.

1.3 Milton Bradley \& Company, The Myriopticon, A Historical Panorama of the Rebellion, 1866. Pasteboard, paper and chromolithography.

1.4 Milton Bradley \& Company, The Historiscope, A Panorama \& History of America, 1868. Pasteboard, paper and chromolithography.

2.1 “The Card House," Godey's Lady's Book and Magazine LXXX, no. 20 (April 1870): 323. Wood engraving.

2.2 Milton Bradley \& Company, The box for The Checkered Game of Life, 1860.

Pasteboard and chromolithography.

2.3 Charles R. Parsons and Lyman W. Atwater, The Four Seasons of Life: Old Age The Season of Rest, 1868. Currier \& Ives lithograph.

2.4 Milton Bradley \& Company, the teetotum for The Checkered Game of Life, 1860. Pasteboard, paper and chromolithography.

2.5 Milton Bradley \& Company, the record dial for The Checkered Game of Life, 1860. Pasteboard, paper and chromolithography.

2.6 W. and S.B. Ives Company, The Mansion of Happiness, 1843. Pasteboard, paper and chromolithography.

2.7 Albert Alden, The Life and Age of Man: Stages of Man's Life from the Cradle to the Grave, wherein all Christians may behold their frail nature and the miseries that attend a sinful life, 1835. Broadside.

2.8 Nathaniel Currier, The Drunkard's Progress: From First Glass to Grave, c. 1848. Hand colored lithograph.

2.9 Currier \& Ives, The Tree of Temperance, 1872. Hand colored lithograph.

3.1 Scene one in the Myriopticon, Major Anderson and his men entering Fort Sumter. Chromolithography on paper scroll. 
3.2 Scene two in the Myriopticon, Bombardment of Fort Sumter. Chromolithography on paper scroll.

3.3 Scene three in the Myriopticon, First Blood shed in the Great Rebellion. Chromolithography on paper scroll.

3.4 Scene four in the Myriopticon, Murder of Colonel Ellsworth. Chromolithography on paper scroll.

3.5 Scene sixteen in the Myriopticon, Sharpshooter. Chromolithography on paper scroll.

3.6 "The Army of the Potomac - A Sharpshooter on Picket Duty - (From a painting by W. Homer, Esq.)," Harper's Weekly VI, no. 307 (November 15, 1862): 724 . Wood engraving.

3.7 Scene fourteen in the Myriopticon, Telegraph Corps erecting telegraph wires. Chromolithography on paper scroll.

3.8 Scene fifteen in the Myriopticon, Wounded being cared for after the Battle of Antietam. Chromolithography on paper scroll.

3.9 Scene eighteen in the Myriopticon, Contrabands coming into camp. Chromolithography on paper scroll.

3.10 "Contrabands Coming into Camp - Drawn by Mr. A.E. Waud," Harper's Weekly VII, no.318 (January 31, 1863): 68. Wood engraving.

3.11 Scene twenty-three in the Myriopticon, Colored troops of the United States enter Charleston, February 1865. Chromolithography on paper scroll.

3.12 Scene nine in the Myriopticon, Fort Donelson. Chromolithography on paper scroll.

3.13 Scene nineteen in the Myriopticon, General Grant at Vicksburg. Chromolithography on paper scroll.

3.14 Scene twenty in the Myriopticon, Washing up after the Battle of Atlanta. Chromolithogrpahy on paper scroll.

3.15 Scene twenty-two in the Myriopticon, Sinking of the 'Alabama.' Chromolithography on paper scroll.

3.16 "The Sinking of the 'Alabama' off Cherbourg, June 19, 1864," Harper's Weekly VIII, no. 395 (July 23, 1864): 465. Wood engraving. 
3.17 Scene twenty-four in the Myriopticon, Burning of Richmond. Chromolithography on paper scroll.

4.1 Scene one in the Historiscope, A group of Native Americans. Chromolithographed on paper scroll.

4.2 Juncture between scene one and scene two in the Historiscope. Chromolithographed on paper scroll.

4.3 Scene two in the Historiscope, Landing of Columbus. Chromolithographed on paper scroll.

4.4 Scene three in the Historiscope, Discovery of the Mississippi River by De Soto. Chromolithographed on paper scroll.

4.5 Scene four in the Historiscope, Discovery of the Hudson River. Chromolithographed on paper scroll.

4.6 Scene five in the Historiscope, Settlement of Jamestown, Virginia. Chromolithographed on paper scroll.

4.7 Scene six in the Historiscope, Pocahontas saving Captain John Smith. Chromolithographed on paper scroll.

4.8 Scene seven in the Historiscope, Landing of the Pilgrims. Chromolithographed on paper scroll.

4.9 Scene eight in the Historiscope, City of New York. Chromolithographed on paper scroll.

4.10 Scene nine in the Historiscope, Treaty of William Penn with the Indians, 1682. Chromolithographed on paper scroll.

4.11 Scene ten in the Historiscope, Roger Williams Pleading with the Sachem of the Narragansetts. Chromolithographed on paper scroll.

4.12 Scene eleven in the Historiscope, Palisaded house. Chromolithographed on paper scroll.

4.13 Charles A. Goodrich, History of the United States of America; for Use of Schools; revised and brought down to the present time by William H. Seavey, principal of the Girl's High and Normal School, Boston (New York: Taintor Brothers, Merrill and Co., 1867), 43. 
4.14 Scene twelve in the Historiscope, Block-house, Kennebec, Maine. Chromolithographed on paper scroll.

4.15 Scene thirteen in the Historiscope, Wadsworth hiding the Charter of Connecticut. Chromolithographed on paper scroll.

4.16 Scene fourteen in the Historiscope, Boston tea party. Chromolithographed on paper scroll.

4.17 Scene fifteen in the Historiscope, Battle of Lexington. Chromolithographed on paper scroll.

4.18 Scene sixteen in the Historiscope, The Battle of Bunker Hill. Chromolithographed on paper scroll.

4.19 John Trumbull, The Death of General Warren at the Battle of Bunker Hill, June 17, 1775, oil on canvas, 1813-1831 (several versions made); Trumbull sold the engraving rights.

4.20 Charles A. Goodrich, History of the United States of America; for Use of Schools; revised and brought down to the present time by William H. Seavey, principal of the Girl's High and Normal School, Boston (New York: Taintor Brothers, Merrill and Co., 1867), 116.

4.21 Scene seventeen in the Historiscope, Bunker Hill monument. Chromolithographed on paper scroll.

4.22 Scene eighteen in the Historiscope, General George Washington as Commander-in-Chief of the American Army.

4.23. Scene nineteen in the Historiscope, Attack on Quebec by the American Army. Chromolithographed on paper scroll.

4.24. Scene twenty in the Historiscope, British Attack on Fort Moultrie. Chromolithographed on paper scroll.

4.25. Scene twenty-one in the Historiscope, Independence Hall. Chromolithographed on paper scroll.

4.26. Scene twenty-two in the Historiscope, Winter at Valley Forge. Chromolithographed on paper scroll.

4.27. Scene twenty-three in the Historiscope, Putnam at Horseneck. Chromolithographed on paper scroll. 
4.28. Scene twenty-four in the Historiscope, Arrest of Major André.

Chromolithographed on paper scroll.

4.29 Scene twenty-five in the Historiscope, Lord Cornwallis surrendering to Washington. Chromolithographed on paper scroll. 


\title{
BIG IDEAS IN LITTLE BOXES: NATION BUILDING IN THREE NINETEENTH-CENTURY AMERICAN PARLOR GAMES BY MILTON BRADLEY \& COMPANY
}

\author{
Margaret Fairgrieve Milanick
}

Dr. Kristin Schwain, Dissertation Supervisor

\begin{abstract}
Milton Bradley \& Company manufactured its first game, The Checkered Game of Life, in 1860, only months before the American Civil War broke out. Soon after, it produced the Myriopticon A Historical Panorama of the Rebellion, and the Historiscope A Panorama and History of America. Producing "moral, instructive and entertaining home amusements" proved to be good business for the company. This dissertation investigates the behaviors, beliefs, assumptions and worldview of midnineteenth-century American society just before and after the American Civil War through the examination of three parlor amusements. Grounding my analysis in the religious, social, visual and material culture of the time, I ask the question: Why would buying and playing these games appeal to families right after the conclusion of the Civil War, at a time when the nation and families struggled to reconstruct themselves? My findings suggest playing these three parlor amusements accomplished at least three ends: reaffirmed the woman's role in the moral education of children and families, confirmed the desire for a united nation, and side stepped any engagement with change in the social and political ideology of that
\end{abstract}


newly united nation. My analysis reveals that the three parlor games I studied acted as guardians of the ideals already established and enshrined in the American origin story told since the late 1700 s and retold in the Historiscope. 


\section{BIG IDEAS IN LITTLE BOXES: NATION BUILDING IN THREE NINETEENTH-CENTURY AMERICAN PARLOR GAMES BY MILTON BRADLEY \& COMPANY}

\section{CHAPTER 1: INTRODUCTION}

On June 3,1865, Harper's Weekly published a provocative illustration, entitled “Check-Mate!," on the front cover of the weekly news magazine. (figure 1.1) The commentary that accompanies this image created a link between the scene of game playing and a historical and political moment in the following words: "The scene is chosen with a sort of mysterious reference to the whole idea that is to be expressed." ${ }^{1}$ Two men, Jefferson Davis in the guise of the Spirit of Treason, and the U.S. federal government in the guise of Uncle Sam, play chess in a monstrous architectural setting, and the play action on the game board defined the reason Davis lost the war, because his deceit, falseness, rapaciousness and cruelty was no match for the resources, industry, self-control and rightness of Uncle Sam. Davis was "beaten at his own game."

"Check Mate!" dramatizes the cultural work a game can do by not only addressing the setting the players play the game in but also the design, images and play action on the game board. This "mysterious" setting is described in the Harper's Weekly article that accompanies the illustration as "a wide vault whose arch is formed by two lizard-shaped monsters, whose heads - half bird, half locust - as well

\footnotetext{
1 __. “Check-Mate," Harper's Weekly Vol. IX, no. 440 (June 3, 1865): 337.

2 Ibid.
} 
as their short, misshapen claws, adhere closely to two pillars, down which they seem to creep. The upper surface of a sarcophagus is transformed into a chess board;" The article concludes that this very architecture "intimates the presence of that dark Being to whose sphere belongs all that is horrible, traitorous, and repulsive." ${ }^{3}$ The design of the game is a checkerboard, and game pieces identify the game as Chess, a game of choices. An analysis of the play action on the board reveals that Davis has made all the wrong choices. Only one piece remains on the side of the Spirit of Treason, General Lee in the guise of Davis's King, "held in check by the KNIGHTS, SHERMAN and SHERIDAN, and mated by the opposition of the Church" in the guise of bishops. ${ }^{4}$ Uncle Sam has made the right choices since almost all of his chess pieces, his resources, are still in play. Those few Union forces captured show in their broken, emaciated forms "the merciless spirit of their captor." 5 The Goddess of Liberty, wearing the Phrygian cap of freedom, stands between the two players with her head and eyes inclined toward Uncle Sam, "a gentle, lovely angel-form, with white and out-spread wings," glowing in the background, the protecting spirit for a united nation. ${ }^{6}$

This image introduces how I use three parlor games, invented and produced just before and after the American Civil War. Each was played within the architectural setting of the parlor, the purview of the woman of the house. The glowing protective angel-form presented in the Harper's Weekly illustration "CheckMate!" connects to a poem included in the June 1863 issue of Godey's Lady's Book

${ }^{3}$ Harper's Weekly, “Check-Mate," 337.

${ }^{4}$ Ibid.

${ }^{5}$ Ibid.

${ }^{6}$ Ibid. 
and Magazine, "The Angel of the House." She not only protected and commanded, but acted as a spiritual guide for everyone in the family:

A perfect woman, nobly planned,

To warn, to comfort, and command;

And yet a spirit, still and bright.

With something of an angel bright. ${ }^{7}$

I investigate the role parlor games had in a woman's arsenal of tools for moral instruction and spiritual guidance within her command post, the parlor. I examine the material design, images, play action and narratives contained within each parlor game and expose how parlor games build the idea of nation at a particular historical moment when anxieties were high over the fragility of that nation. In this dissertation, the study of parlor games shines a light on the hidden discourses of gender, racism, and Protestantism that pervade that concept of nation. ${ }^{8}$

I argue that these three parlor games were used as a moral and social force to elevate and educate Americans, to unify the mid-nineteenth-century American nation. I use the term "parlor games" as an umbrella term for social games and home amusements created by producers as "moral, instructive and entertaining" products for the whole family, and even guests, to play in the parlor. ${ }^{9}$ The three

\footnotetext{
${ }^{7}$ Sarah J. Hale, “Editor's Table,” Godey's Lady's Book and Magazine LXVI (June 1863): 578.

${ }^{8}$ Martin Berger, Sight Unseen: Whiteness and American Visual Culture (Berkeley, LA, London: University of California Press, 2005), 24.

${ }^{9}$ Milton Bradley \& Co., "Directions to the Proprietor of the Myriopticon," one sheet. I have specifically not used the term "toy" because the term implies an object only children played with. By using the term "parlor games," I am implying the games I studied were played by adults and children. Although "parlor games" is not a term frequently used in mid-nineteenth century America (it is a term used in the $20^{\text {th }}$ and
} 
parlor games I investigate are: The Checkered Game of Life, a board game first manufactured by Milton Bradley \& Co. in 1860; the Myriopticon, a miniature moving panorama that tells the story of the Great Rebellion in twenty-four scenes and an accompanying seven page script, produced in 1866; and the Historiscope, a miniature moving panorama that tells the history of the United States in twenty-five scenes and an accompanying eight page script, produced in 1868. (figures $1.2-1.4$ ) All three parlor games were manufactured by the Springfield, Massachusetts firm Milton Bradley \& Company.

I examine these three parlor games as material culture, as manifestations of nineteenth-century American culture through its material productions, and my ideas are influenced by the art historian Jules Prown. The parlor games I chose embody beliefs of the individuals who made them and by extension the beliefs of the larger society to which they belonged. ${ }^{10}$ I examine these material objects as historical events. ${ }^{11}$ Although they were created in the past, they continue to exist in our own time, and therefore are primary evidence available for firsthand study of the values, ideas, attitudes and assumptions that existed in America just before and after the Civil War. ${ }^{12}$ I explore their interface with American education, developing

$21^{\text {st }}$ centuries to denote games played in the nineteenth-century American parlor), there were so many terms used in nineteenth-century America, I have opted for a general term that has meaning in the $21^{\text {st }}$ century. Some of the terms used in nineteenth-century America for what we call "parlor games" in the $21^{\text {st }}$ century were: home amusements, social games, in-door games, recreations, musical games, games of memory, natural magic, social sports, parlor tricks, acting charades, etc. ${ }^{10}$ Jules David Prown, "Mind in Matter: An Introduction to Material Culture Theory and Method," in Art As Evidence: Writings on Art and Material Culture (New Haven and London: Yale University Press, 2001), 70.

11 Ibid, 220.

12 Ibid, 221. 
concepts of national identity and history, a changing economic system, changing religion, and changing gender roles.

However, parlor games are more traditionally written about as toys and from the perspective of their history, beginning in colonial times up to present times, or from the perspective of collecting. For example, Richard O'Brien included The Checkered Game of Life, the Historiscope and the Myriopticon in The Story of American Toys from the Puritans to the Present (1990), a history of American toys, and Katharine Morrison McClinton included all three in her compendium of collecting, Antiques of American Childhood (1970). Emily Schultz wrote about "The Historiscope: A Nineteenth-Century American History Toy" in Cincinnati Fourteen (2007) in which she describes the moving panorama as a toy for children that teaches history, but does not connect it to the culture of its time. James Marten, in "History in a Box: Milton Bradley's Myriopticon" in The Journal of the History of Childhood and Youth (2009), writes about the miniature moving panorama as an example of the increasing presence of commercially produced toys and games slickly packaged. Marten states the Myriopticon "offered a comprehensive experience requiring little imagination from its young consumers" but he never engages with the images themselves or the story that is told with these images and the accompanying lecture, or asks the question: Why is the story being told? ${ }^{13}$

Parlor games have not been investigated as material objects by scholars. I could find no evidence that anyone had written about their materials and design as

${ }^{13}$ James Marten, "History in a Box: Milton Bradley's Myriopticon," in The Journal of the History of Childhood and Youth 2,no. 1 (Winter 2009): 7. 
a link to answer questions about the economic and social systems of the time. Neither has anyone systematically searched for the sources for all the scenes in the Myriopticon and Historiscope, or done close readings of those images, or asked what story is being told and why. Nor could I find evidence that anyone had contextualized the design and images of The Checkered Game of Life, or the tension embedded in its play action. One article, "Making Your Move: The Educational Significance of the American Board Game, 1832 to 1904," published in History of Education Quarterly (1977) by David Wallace Adams and Victor Edmonds, does connect The Checkered Game of Life to changing concepts of success in the economic world of nineteenth-century America, but does not then ask the question why would middle-class American families be interested in purchasing and playing a game with this message?

Along with not venturing beyond describing parlor games as children's toys or collectibles, most scholars have not engaged with their performance. Given that parlor games were performed in the parlor, not just children, but the whole family was involved in playing them. Therefore, I have investigated what would make each game an attractive addition to evening entertainment for all members of the family and even guests in the parlor. In a letter to Milton Bradley \& Company, satisfied customer B.R. Davis, head of a family of five children, described just how entertaining the performance of the Myriopticon was when he wrote: "Some other neighbors of ours the R's, acting put out as a result of not being invited to the first Lecture, we asked them in the next evening to see and hear my Lecture. They numbered five, among them being the Grandmother who is deaf as a post but she 
enjoyed the pictures anyway."14 In chapter three, I answer the question: Why would Davis's family and guests find the Myriopticon performance interesting enough for multiple evenings of parlor entertainment?

The Myriopticon and Historiscope are different from The Checkered Game of Life in ways that require additional considerations because they not only require performing, but also set the images they are made up of in motion. Milton Bradley \& Company modeled the Myriopticon and Historiscope after large moving panoramas popular in the United States in the 1840s and ' $50 \mathrm{~s} .{ }^{15}$ Although the first panoramas arrived in New York City in 1795, they were three hundred sixty degree circular, static panoramas requiring dedicated rotunda buildings for viewing, and were not very successful at that time in the United States. ${ }^{16}$ Americans did not want to see European imperialist subject matter, and American entrepreneurs could not cover the cost of production and make a reasonable profit since American cities did not yet have the population to garner viewing audiences large enough. What was successful were "moving panoramas" and the first in the United States date to 1830.17 Moving panoramas could be transported and set up for display much more easily and cheaply, and required only a hall of some kind, available in many towns in the United States. Among the most successful was Banvard's Panorama of the Mississippi River (1846), allowing Americans to see the vast landscape of the

\footnotetext{
${ }^{14}$ James J. Shea as told to Charles Mercer, It's All in the Game (New York: G.P. Putnam's Sons, 1960), 81.

${ }^{15}$ Milton Bradley \& Company, Work and Play Annual of Home Amusements and Social Sports (Springfield, Mass.: Milton Bradley and Co., 1871-72), 36.

${ }^{16}$ Stephan Oettermann, The Panorama: History of a Mass Medium, trans. by Deborah Lucas Schneider (New York: Zone Books, 1997), 313.

17 Ibid, 314.
} 
Mississippi unroll before their eyes as if they were traveling on the river themselves. In urban centers, the popularity of moving panoramas peaked around 1850, declining by 1862 . However, a second phase of panorama popularity began in America in the early 1880s. These panoramas were static, mounted in rotundas, and were usually called "cycloramas" to distinguish them from the better known "moving panoramas," and the "panoramas" popular earlier in Europe. ${ }^{18}$

Most scholars who write about panoramas study static panoramas and do not contextualize their images. Stephan Oettermann, in Panorama: History of a Mass Medium (trans. 1997), studied primarily static circular panoramas and treats them, but not their images, as a symbolic form of a modern bourgeois view of the world. Denise Blake Oleksijczuk, in The First Panoramas: Visions of British Imperialism (2011), contextualizes the subject of specific static circular panoramas, but does no close readings of the images themselves or their organization. However, intriguingly, she investigates how the first circular panoramas of Britain, 1787 through 1820, became loci for ideology by exploring how they positioned spectators. She does this by studying the changes in the circular panorama form, subject matter and written material called keys that oriented observers, and contends their development became increasingly manipulative.

When scholars have written about moving panoramas, I have been unable to find work that addresses what putting all the images in motion does. Instead, I have found work that fits moving panoramas into an existing framework of academic painting and architecture, for example in Mississippi Panorama edited by Perry T.

18 Oettermann, The Panorama: History of a Mass Medium, 342. 
Rathbone (1950) or Peter and Julia Morelli's “The Moving Panorama of Pilgrim's Progress: The Hudson River School's Moving Exhibition" in The Panorama in the Old World and the New edited by Gabriele Koller (2010). Some scholars have written about panoramas within the rubric of media history. John Francis McDermott, in The Lost Panoramas of the Mississippi (1958), reclaims the lost "huge panoramic shows of the 1840s" in the United States, tracing their technological development. Jonathan Crary in Techniques of the Observer: On Vision and Modernity in the Nineteenth Century (1990), Barbara Maria Stafford and Frances Terpak in Devices of Wonder: From the World in a Box to Images on a Screen (2001), and Erkki Huhtamo in Illusions in Motion: Media Archaeology of Moving Panorama and Related Spectacles (2013) situate optical devices, among them moving panoramas, in a broader technological system and fit them into theories and practices of visual communication. The essays in The Panorama in the Old World and the New (2010), describe moving panoramas from around the world, establishing them as important visual media.

Jennifer Lynn Peterson, in "The Historiscope and the Milton Bradley Company: Art and Commerce in Nineteenth-Century Aesthetic Education" in Getty Research Journal (2014), contextualizes the idea of the Historiscope but never engages with the object itself: the actual images, how they are organized, what setting them in motion does, and what narrative is produced and why. However, Peterson does conclude that the Historiscope is a "device with a linear, episodic 
logic."19 This is how a story is told. My ideas about how the two moving panoramas tell stories and why, are informed by the art historians Patricia M. Burnham's and Lucretia Hoover Giese's ideas in the introduction to their edited volume Redefining American History Painting (1995), and the historian Wolfgang Schivelbusch in The Railway Journey: The Industrialization of Time and Space in the $19^{\text {th }}$ Century, trans. by Anselm Holo (1986).

Using ideas from Burnham and Giese, and Schivelbusch, I examine how the Myriopticon and Historiscope construct stories through the use of literary devices and modern panoramic vision. ${ }^{20}$ The linear arrangement of events used in both miniature moving panoramas create beginnings, middles and ends that suggest causality. ${ }^{21}$ Literally setting those scenes in motion strips the events of their complexity. In their original time and space, these events belonged to separate realms but now motion has shrunk time and space, allowing for the audience to see discrete events indiscriminately. ${ }^{22}$ This disjunction of time and space dissolves the realities of separate events, replacing them with the panoramic vision of a new history. This process allows for the insertion of ideologies, creating history with a

${ }^{19}$ Jennifer Lynn Peterson, "The Historiscope and the Milton Bradley Company: Art and Commerce in Nineteenth-Century Aesthetic Education," Getty Research Journal 6 (January 2014): 180.

${ }^{20}$ Patricia M. Burnham and Lucretia Hoover Giese, "Introduction," in Redefining American History Painting, eds. Patricia M. Burnham and Lucretia Hoover Giese (Cambridge and New York: Cambridge University Press, 1995), 8. Wolfgang Schivelbusch, The Railway Journey: The Industrialization of Time and Space in the Nineteenth Century, trans. by Anselm Holo (Berkeley: University of California Press, 1986), 64.

${ }^{21}$ Burnham and Giese, "Introduction," 9.

${ }^{22}$ Schivelbusch, The Railway Journey, 60. 
particular point of view. ${ }^{23}$ The two miniature moving panoramas I study become agents for the dissolution of reality, resurrected as the idea of nation. ${ }^{24}$ I analyze what that idea of nation was.

I have chosen to study The Checkered Game of Life, the Historiscope and the Myriopticon as material culture for several reasons. The space they were all performed in, the parlor, allows for further investigation into gender, economic, religious and political attitudes within the culture at that time. I explore how and why these three parlor games participated in the process of instructing nineteenthcentury Americans in how they should see themselves as citizens of the American nation at a time when that nation was in grave danger. They integrated both personal and national goals of unity within the family and the home by fostering uniform communities, molding socially homogenous men and women, and rewarding a set of national virtues informed by evangelical Protestant thinking. These three parlor games function in my analysis presented in this dissertation as a response to the consumerism demanded by a continually developing industrial capitalist economic system within a nation that needed coherence, unity and stability to prosper. $^{25}$

My ideas about the relationship between parlor games and the social and economic changes taking place in nineteenth-century American society are informed by the social historian, Mary Ryan, in her book Cradle of the Middle Class:

\footnotetext{
${ }^{23}$ Denise Blake Oleksijczuk, The First Panoramas: Visions of British Imperialism (Minneapolis and London: University of Minnesota Press, 2011), 3.

${ }^{24}$ Schivelbush, The Railway Journey, 64.

${ }^{25}$ Clifford Edward Clark, Jr., The American Family Home, 1800-1960 (Chapel Hill and London: The University of North Carolina Press, 1986), 36.
} 
The Family in Oneida County, New York, 1790-1865 (1981). I use her model to uncover the role played by economic change in determining the tasks by which citizens are produced, and to reveal how playing games in the parlor, and more specifically the play action and narratives told in the parlor games I have chosen, participated in that process. As the nation moved from an agrarian to an industrial economy, the function of the family changed from a producing unit to a consuming unit. By the 1840s and 1850s, the factory system began to flourish with the development of large-scale enterprises (ex. railroads, public education, professions). This changed the nature of production and increasingly resulted in separation of the workplace and living space as growing numbers of middle-class men during the nineteenth century worked outside the home as professionals or businessmen. The industrial economy divided the family by their labor and the profits they created, and this new family economy allowed for independent action. This could be expressed by behaving virtuously, choosing public over private interest, or in cavalier self-interest. ${ }^{26}$ I examine what kind of independent action was rewarded in the three parlor games I chose for study.

Because the old order of patriarchal rule in the family was disrupted, reformers and entrepreneurs worked to establish a new middle-class ideal for the American family home through print capitalism: by producing, for example, advice manuals, ladies magazines, news magazine, and parlor games. This new ideal called for women to dominate the home and consumption, and to assume the central role in raising children with subtler and gentler means to instill parental values in order

${ }^{26}$ Mary P. Ryan, Cradle of the Middle Class: The Family in Oneida County, New York, 1790-1865 (Cambridge, London, New York: Cambridge University Press, 1981), 231. 
to create the virtuous citizen. ${ }^{27}$ The words, manuals, or products I will use to build my argument come from such figures as the educator and writer Catharine Beecher (1800-1878), the popular author Harriet Beecher Stowe (1811-1896), the Congregational minister and theologian Horace Bushnell (1802-1876), the landscape architect, horticulturalist, and writer Andrew Jackson Downing (18151852), the writer and influential editor of Godey's Lady's Book Sarah Josepha Hale (1788-1879), and Milton Bradley (1836-1911), founder of Milton Bradley \& Company.

The parlor became the perfect stage for the performance of parlor games within middle-class culture in nineteenth-century America. Especially in urban settings, the parlor became the transition zone between the outside industrial world of commerce and the family. The at-home mother who served as the arbiter of moral education and persuasion used the parlor as her command center. ${ }^{28}$ It was placed in the house so that it was easily accessible from the street but was insulated from the everyday family rooms. This ideal gave parlor games moral attributes that supplied the proper associations for protection, inspiration, closeness and cooperation, and greater appreciation of art and beauty for the American family. A write-up for The Checkered Game of Life in Work and Play Annual, published by Milton Bradley \& Co. in 1871-72 echoes these very attributes:

THE CHECKERED GAME OF LIFE was among the first that served to inaugurate the introduction of moral and instructive games and amusements into our homes, and the steady increase in the use of

27Ibid, 232.

28 Sally McMurray, "City Parlor, Country Sitting Room: Rural Vernacular Design and the American Parlor, 1840-1900," Winterthur Portfolio 20, no. 4 (Winter, 1985): 262. 
such amusements in all the intelligent families of the whole country during the last few years is due largely to the value of this, and a few other equally good games, that originally served to break down an unjust prejudice against all home amusements. ${ }^{29}$

Parlor games were seen as a product the woman of the house could purchase and implement, to unify the family at the end of a day of disparate activities, and to morally instruct the family to help produce virtuous citizens of the nation. The clergyman Horace Bushnell called for the Protestant home to become the place where children were nurtured by parents who set a virtuous example, in the belief that environment shaped character. He saw the future of the nation ultimately dependent on loyalty to a Protestant ideal of voluntary acquiescence to the laws of God that would counter selfishness. ${ }^{30}$ He and other reformers put women in charge of the rehabilitation of society by countering the avarice encouraged in the business world and the corruption generated in politics. Sarah J. Hale wrote in her "Domestic Economy" column in Godey's Lady's Book and Magazine: "And not only in domestic life is the moral effect of women's character and conduct thus influential, but the prosperity and greatness of the nation are equally dependent upon her."31

My ideas about nation-building are informed by the political scientist and historian, Benedict Anderson, in his seminal text Imagined Communities: Reflections on the Origin and Spread of Nationalism (2006). I therefore define nation as "an imagined political community - and imagined as both inherently limited and

${ }^{29}$ Milton Bradley \& Co., Work and Play Annual, 37. 30 Lawrence Cremin, American Education: The National Experience 1783-1876 (New York: Harper and Row, 1980), 49.

31 Clark, The American Family Home, 32. 
sovereign." ${ }^{2}$ I examine the three parlor games for the ways they help nineteenthcentury players imagine their nation. Since nations are imagined as fraternities, I investigate the construction of gender within the play action images and narratives of the parlor games. Nations are also imagined as sovereign and because the idea of nation creates deep emotional attachments, I investigate the violence inherent in the play action and narratives in these parlor games. ${ }^{33}$ Because nations are imagined as limited, since no nation is imagined as one day including all of mankind, I investigate the racism inherent in the play action and narratives within the three parlor games. ${ }^{34}$ I use Anderson's model to highlight the virtues rewarded in The Checkered Game of Life, to connect them to the story told in the Historiscope, to showcase the importance of that story to the idea of nation, and to understand the implications of the story told of the Civil War in the Myriopticon right after the conclusion of the war, a story that is very different from the story told today.

Anderson connects the facilitation of the idea of nation to print capitalism, and I use this model to situate all three parlor games within the visual and textual publications of the times. Indeed, the nineteenth century saw an explosion in printed reading materials in the form of magazines, readers, textbooks on all subjects, domestic manuals, advice books, plan-books for domestic architecture, pattern books for interior decoration, religious tract publications, novels, popular

\footnotetext{
${ }^{32}$ Benedict Anderson, Imagined Communities: Reflections on the Origin and Spread of Nationalism, revised edition (London and New York: Verso, 2006), 6.

${ }^{33}$ Ruth Roach Pierson, "Nations: Gendered, Racialized, Crossed With Empire," in Gendered Nations: Nationalisms and Gender Order in the Long Nineteenth Century, edited by Ida Blom, Karen Hagemann, Catherine Hall (Oxford, New York: Berg Publishers, 2000), 42.

${ }^{34}$ Pierson, "Nations: Gendered, Racialized, Crossed With Empire," 42.
} 
prints, etc. I investigate the intersection of ideas on nation, family and roles of men and women citizens present in the three parlor games with the images and essays included in such publications as: Godey's Lady's Book and Magazine which started publication in 1830 and by 1860 was one of the most widely read women's magazines in the United States with a circulation of 150,000; Harper's Weekly Magazine which started publication in 1857 and by 1863, had a readership of 500,$000 ; 35$ popular prints lithographed by the Currier firm begun in 1835 and the Kellogg Brothers firm in c. $1830 ;{ }^{36}$ domestic manuals such as $A$ Treatise on Domestic Economy, first published by Catharine Beecher in 1841, and subsequently reprinted fifteen times, ${ }^{37}$ as well as The American Woman's Home, co-written with her sister, Harriet Beecher Stowe published in 1869; and the McGuffey series of readers which sold forty-seven million copies between 1836 and $1870 .^{38}$

Reconstruction, traditionally considered to cover the years 1865 to 1877 , involved the readmission of the Confederate States to the Union, and much of the policy enacted was educational. ${ }^{39}$ My ideas about education in America in the nineteenth century have been informed by the educational historian Lawrence Cremin, in his volume American Education: The National Experience, 1783-1876

35 Eugene Exman, The House of Harper: One Hundred and Fifty Years of Publishing (New York, Evanston and London: Harper and Row Publishers, 1967), 84.

${ }^{36}$ Nancy Finlay, "Introduction: Taking a Fresh Look at Nineteenth-Century Lithography," in Picturing Victorian America: Prints by the Kellogg Brothers of Hartford, Connecticut, 1830-1880 [exh. cat.], ed. Nancy Finlay (Hartford, CT: Connecticut Historical Society, 2009), 2.

${ }^{37}$ Kathryn Kish Sklar, Catharine Beecher: A Study in American Domesticity (New Haven and London: Yale University Press, 1973), 305, footnote 1.

${ }^{38}$ Cremin, American Education, 69.

${ }^{39}$ John White, Reconstruction after the American Civil War, part of Seminar Studies in History, ed. Patrick Richardson (London: Longman Group Ltd., 1977), v; Cremin, American Education, 517. 
(1980). Northern ideas of what a united nation should be were widely disseminated in print media, including parlor games. Therefore, I compare the images used, the characteristics rewarded, and the narratives embedded in the parlor games I chose, to the history textbooks available at the time these parlor games were manufactured. I study such authors' histories as Noah Webster, Samuel G. Goodrich, Charles A. Goodrich, Benson J. Lossing, Richard Hildreth, William H. McGuffey and Jacob K. Neff. I examine what picture of a united nation was created just after the Civil War in the images, play action and narratives of the three parlor games, and compare it to the picture formed in the antebellum years. The Civil War itself educated the public in new attitudes, knowledge, and behaviors necessary to thrive in the postwar period. It exposed Americans to large-scale institutional organization in the areas of education, agriculture, manufacturing, communications, and transportation that was the reality of the future of the industrial capitalist economic system of postwar America. I examine how these parlor games I chose address this future.

These parlor games trained family members in virtue and orderly participation, promoting a united community with common aspirations, necessary for the formation of nation. ${ }^{40}$ As a tool to educate, they helped define an American culture that was Protestant. ${ }^{41}$ As the educational historian Lawrence Cremin eloquently states: "The only way for the great experiment in liberty to succeed would be under the watchful eye of a virtuous citizenry. And the only way to nurture a virtuous citizenry would be via the beneficent influence of evangelical

${ }^{40}$ Cremin, American Education, 498.

${ }^{41}$ Ibid, 496. 
Protestantism." 42 I investigate how the "beneficent influences" of Protestant evangelicalism manifest themselves in the three parlor games I have chosen. David Morgan's ideas in Protestants and Pictures: Religion, Visual Culture, and the Age of American Mass Production (1999) allow me to investigate the parlor games' designs, images, stories told and their contexts in order to cast an illuminating light on what ways Protestantism was entangled with the concept of nation in mid-nineteenthcentury America.

During the nineteenth century, Protestantism underwent a major change from Calvinism to evangelical and liberal Protestantism. ${ }^{43}$ Evangelical Protestantism located moral agency in the individual and encouraged active missionary work, just as American national politics required interest, scrutiny and active participation also. ${ }^{44}$ Churches, schools, colleges and families shared the education of the young and trained them in virtue and orderly participation within a community, and taught what was believed to be the necessary information to avoid "crass individual self-interest." 45 These attitudes and skills of agency and participation created a national attitude of reform manifested in a belief in responsive leadership, socially just allocation of goods, technological invention and innovation, and led to the reality of social mobility. ${ }^{46}$ Education in America was not pursued for it own sake but as an instrument for personal and social advancement.

\footnotetext{
42Ibid, 57.

${ }^{43}$ David Morgan, Protestants and Pictures: Religion, Visual Culture, and the Age of American Mass Production (New York and Oxford: Oxford University Press, 1999), 268.

${ }^{44}$ Cremin, American Education, 212.

45 Ibid, 495.

46 Ibid, 496.
} 
Middle-class status was conferred by what you knew, not just whom you knew or what you owned. Therefore, I examine the play action and narratives in these parlor games to explain why these games were attractive to middle-class American families and how the knowledge contained in them was represented as bettering everyday life.

The performances required of players of these parlor games emphasized individual agency, participation and lecturing, and were influenced by the evangelical Protestant tradition of study and interpretation. ${ }^{47}$ This tradition revolved around reading, lecturing, and the formal exchange of ideas contained in a plethora of ephemeral printed materials from such nineteenth-century Protestant organizations as The American Tract Society, the American Bible Society, and the American Sunday School Union. ${ }^{48}$ This tradition also gave rise in the nineteenth century to the great age of the lecture, as a rhetorical, didactic and literary form. ${ }^{49}$ Citizens of the United States in the nineteenth century were well acquainted with listening and learning from lectures similar to those included with the Myriopticon and Historiscope from the success of the Lyceum Movement. It began in 1826 and brought lecturers who taught on almost any conceivable topic to villages, towns, and cities all over the nation. ${ }^{50}$

A manifestation of the evangelical and liberal Protestant emphasis on agency and participation was the belief that social reform could move American society

47 Cremin, American Education, 312.

48 Morgan, Protestants and Pictures, 21.

${ }^{49}$ Cremin, American Education, 311.

${ }^{50}$ Carl Bode, The American Lyceum: Town Meeting of the Mind (New York: Oxford University Press, 1956), 7. 
toward perfection, a higher level of civilization, and that America had a special role to play in the dawn of the millennial. ${ }^{51}$ The American family was the key instrument in this campaign. Reformers hoped to banish vice and create a more stabile perfect society by utilizing nature's moral laws. ${ }^{52}$ The household, therefore, was constructed as a refuge from the outside world to strengthen individuals from within and by doing that, strengthen the nation. In the July 1865 issue of Godey's Lady's Book and Magazine, these ideas were echoed in "The Family Circle" column: "What an incalculable influence it brings to bear upon the development of our best capabilities! ... The family circle is a scenic representation to young hearts of that higher world of relationships wherein humanity is to reach its perfection." ${ }^{33} \mathrm{I}$ examine how parlor games aided this endeavor to strengthen the family, and thereby the nation.

However, there lay basic tensions in both the ideal of home and the ideal of domesticity because citizens were indoctrinated with the Protestant value of how to think and act for the good of many but were rewarded for the exercise of selfinterest by an industrial capitalist economic system. The home symbolized personal independence, family self-sufficiency, freedom of choice and private enterprise, all favored by capitalism. Therefore, the home encouraged freedom, but counseled control (virtuous self-denial to plan for the public good). The ideology of domesticity manifested these same tensions since it encouraged freedom but

\footnotetext{
${ }^{51}$ Morgan, Protestants and Pictures, 30. Millennialism is the belief in a future 1000 year age of blessedness, beginning with or culminating in the Second Coming of Christ. Succinctly, it is the belief in a future Utopian Age.

${ }^{52}$ Clark, The American Family Home, 28.

53 . "The Family Circle," Godey's Lady's Book and Magazine LXX (July 1865): 67.
} 
counseled control (virtuous self-denial). The creation of an ideology of domesticity was a way to mobilize energies but at the same time keep tight control over behavior. ${ }^{54}$ I examine the ways in which these three parlor games were instruments of Protestant values, as well as how they constructed gender and race, and connect that with how these parlor games constructed the ideal American citizen.

My thinking about gender and race is informed by the Americanist Martin Berger's ideas in Sight Unseen: Whiteness and American Visual Culture (2005). Through his model, I expose the cultural biases in the nineteenth-century parlor games I study. I analyze how the visual images, play action and narratives of all three parlor games confirm meanings for which the discourses and structures of nineteenth-century society had already predisposed the audience. ${ }^{55}$ I also use this model because it makes me more aware of the internalization of racial and gender biases that may be present in my own analyses, analyses that often privilege visual evidence and therefore, only what is seen. Therefore, I use Berger's model to explore the omnipresent absence of women in all three parlor games I interpret, and the invisible discourses that account for the presences and absences of whites as well as indigenous peoples in the Historiscope, and whites and blacks in the Myriopticon. Using Berger's ideas, I uncover how invisible discourses of gender and race that permeated the picture of nation were impressed on and expressed by these parlor games.

\footnotetext{
${ }^{54}$ Sarah A. Leavitt, From Catharine Beecher to Martha Stewart: A Cultural History of Domestic Advice (Chapel Hill and London: The University of North Carolina Press, 2002), 35.

55 Berger, Sight Unseen, 1.
} 
In summary, this dissertation engages with parlor games as material objects that involve performance to connect these games to the political, social, economic, religious and historical times they come from. To do this, I:

- track down the sources for the images, examine how these sources inform meaning, do close readings of images and play action;

○ note how the juxtapositions and organization of scenes interact to create specific stories, analyze what play action leads to winning;

$\circ$ investigate what lessons were taught;

- connect those lessons and stories to the visual and textual culture of midnineteenth century America;

○ explore the parlor performance within the context of theater in midnineteenth-century America;

$\circ$ research the significance of the parlor and why playing games in the family would be a popular evening activity.

I ask:

- Why these images,_organized that way?

- Why would a family find a performance of the story of the Civil War or American history compelling in mid-nineteenth century America?

- Why does the board game The Checkered Game of Life use the accumulation of one hundred points of virtues as the measure of success?

- What purpose did lessons taught or stories told serve in the larger culture?

- How did these objects construct race and gender? 
I answer these questions and more in chapters two, three and four of this dissertation.

My questions are informed by the writings of art historian Mary Sheriff, who steps outside the usual way of looking at an object. She asks questions of an object that will lead to a better understanding of the culture that produced it. In turn, under her influence, I ask: Do my interpretations provide for a better understanding of the society the object in question was produced in or is being interpreted in? ${ }^{56}$

\footnotetext{
56 Mary Sheriff, “The Cradle is Empty: Elisabeth Vigée-Lebrun, Marie-Antoinette, and the Problem of Intention," in Women, Art and the Politics of Identity in EighteenthCentury Europe, eds. Melissa Hyde and Jennifer Milam (Burlington, VT: Ashgate, 2003): 169.
} 


\section{CHAPTER 2: THE CHECKERED GAME OF LIFE MORAL ENTERTAINMENT IN THE PARLOR}

The Card House and the ideology of domesticity

The full page wood engraving, The Card House, appeared in the April 1870 issue of Godey's Lady's Book and Magazine, and demonstrated new technology enlisted to define the norms expected of mid-nineteenth-century Americans..$^{57}$ (figure 2.1) The wood engraving process conformed much better to the needs of industry than metal plate engraving used earlier in the century, making it easier to mass produce ephemeral materials like magazines. A relief process done with the letterpress, wood engraving accommodated the thinner paper used in magazines and required much less time in production. This process facilitated the mass production of packaged domestic advice that carried with it the authority of oral communication with a trusted friend or relative such as that found in Godey's Lady's Book and Magazine. 58

The composition of The Card House visually constructed the gender dynamics of the time. The setting is the parlor. The nineteenth-century viewer would have known this because they are given enough of a view of the elements that were considered essential to the parlor: a decorated mantle, patterned wallpaper, "fancy"

57 __. "The Card House," Godey's Lady's Book and Magazine LXXX, no. 20 (April 1870): 323.

${ }^{58}$ Morgan, Protestants and Pictures, 25. 
chairs, and a center table around which a mother and her three children are gathered. The mother is the largest figure in the composition and she is placed closest to the viewer, making her the most important figure in the home. She leans forward in her chair, her head turned in an affectionate way toward her three children who surround her. The text from the article "Home As It Should Be," published in the May 1866 issue of Godey's Lady's Book and Magazine, echoes this gender dynamic:

It is here that the husband and father finds rest and recreation from the toils and cares of a perplexing business life, and the wife and mother finds her greatest earthly enjoyments, also her greatest sorrows, temptations, and trials. Every faculty of mind and body is brought into requisition, and she stands the centre and the sun of the planetary world, whose wisdom and judgment maintain the order and beauty of the revolving system. ${ }^{59}$

The father is noticeably absent from The Card House private sphere for there is no place included for him at the center table. His days were concerned with "the toils and cares of a perplexing business world." Demonstrating her domestic industriousness, the mother holds sewing/mending on her lap, but she has paused to admire the building skills of her son. The mother and son are placed opposite each other at the center table, their heads composed at the same level and elevated over the other two children's heads, ensuring that it is clear they share a special bond. The builder's sister hands him the next card. The youngest child, barely able to peep over the lip of the center table, watches his older sibling with all his attention.

59 , "Home As It Should Be," Godey's Lady's Book and Magazine, LXXII (May 1866): 437. 
The Card House carefully constructed a scene of maternal nurturing. The engraving showed how the order and experience of family life by mid-nineteenth century had shifted from patriarchal authority to domestic attention. The Card House constructed the bond between mother and children as central in the family and exemplified a new concept for socializing children, accomplished by a mother's tender ministrations, not by a father's strict authoritarian rule. The expectation in a nineteenth-century middle class American family, therefore, was a mother who stayed in the private sphere to raise the children; a sober, industrious father who worked for the family in the public sphere; and docile, well-behaved children closely monitored by their mother. The mother guided the son from the inside world of maternal care to launch him into the wider outside world of masculine work. The Card House defined the middle-class family as the most important platform in American society for developing a virtuous Christian citizenry to ensure moral order and civil liberties. ${ }^{60}$ The family provided a stable social framework to accomplish these goals - women to teach values, and the parlor as the perfect venue for this instruction.

The play action we see in The Card House, of a boy building a house of cards, connected this wood engraving to a particular historical and political moment. The house would have reminded any nineteenth-century American of Abraham Lincoln's famous "House Divided" speech made on June 18, 1858 before the Illinois Republican Party State Convention when he accepted their nomination for the U.S. Senate. His famous words "A house divided against itself cannot stand" was

${ }^{60}$ Morgan, Protestants and Pictures, 58. 
conjured up by the fragile house of cards being built in this engraving by the son, a male citizen in training, nurtured by his mother whose job it was to teach him the sobriety, industriousness and perseverance necessary to be successful in the public sphere. The builder's sister, a female citizen in training, supported and assisted him by handing him the next card. This house was stable enough to support the expansion of yet another floor. Connected to its historical context, the card house being built represented a nation united. The Card House illustrated behaviors considered appropriate for citizens of the American nation. The mother guided the building of national unity, an exemplar and teacher of a national Christian morality. ${ }^{61}$ The very form of the composition, a circle, illustrated the cyclical configuration of the orderly passing on of Christianized civilization to generations of American citizens in training. ${ }^{62}$

The Checkered Game of Life

I have used this exercise in the close reading of the visual image The Card House to introduce several important themes that I will use in this chapter to connect a material object, the parlor game The Checkered Game of Life, and by extension the Myriopticon and Historiscope, to the cultural, political and economic life of mid-nineteenth-century America. One theme is the role the parlor plays in the family and why games would be played there. Another is the how the game might be used by women to accomplish the role they play in the family. Another theme

${ }^{61}$ Sklar, Catharine Beecher, 172.

${ }^{62}$ Michael Yonan, "Toward a Fusion of Art History and Material Culture Studies," West $86^{\text {th }} 18$ no. 2 (Fall-Winter 2011): 110. 
involves performance as cultural work because playing parlor games always involved a performance, allowing for the rehearsal of behaviors reinforced in the play action or narrative of these parlor games. By interpreting The Checkered Game of Life, I illuminate the values considered appropriate for citizens of the American nation that are informed by the historical context of gender, the economy, education and religion.

Thesis

The commodity that earned success for Milton Bradley \& Company was the parlor board game The Checkered Game of Life, manufactured in 1860. The Checkered Game of Life embodied the tension present in a nation founded on democratic principles that supported individual action for the greater good, but that was also saddled with a Capitalist economic system that rewarded individual acquisitive and even rapacious behaviors. The goal of the game required the accumulation of one hundred points of virtues, while including a minefield of vices that severely retarded the accumulation of those points. These same virtues were celebrated and vices warned against in the American family, churches, schools, colleges, textbooks, and popular publications of all kinds. Through performing the game, players practiced the attitudes, values, behaviors and norms expected of citizens of America, calculated to ensure the maintenance of Christian (in nineteenth-century America this always meant Protestant) moral codes in an 
industrial economy predicated on a very different set of values. ${ }^{63}$ The game, therefore, mediated between the public and private spheres by calling for one code of manners applied to both spheres, a position in agreement with writers of the time like Catharine Beecher. ${ }^{64}$ This promoted a homogenous culture for the nation; all Americans, male and female, could shape the character of the nation with common Protestant moral principles, thereby promoting national unity.

The parlor

Milton Bradley \& Co.'s publication Work and Play Annual of Home Amusements and Social Sports from 1871-72 described how games were perfect for keeping the family together to counteract the forces of evil in the outside world. The introduction of the magazine exhorts every parent to "multiply the attractions within until the HOME (their emphasis) becomes the pleasantest place on earth to every member of the family," to avoid what the magazine called "the traps of Satan" lurking right outside the doors of every home. ${ }^{65}$ Milton Bradley \& Co. makes it clear:

...there is no class of influences more potent than the introduction of social games and sports, and it is in this direction that the publishers of this little book have been working for several years in the production of a class of innocent and instructive recreations, a proper use of which in every family of young folks will guarantee the

\footnotetext{
${ }^{63}$ Robert T. Handy, A Christian America: Protestant Hopes and Historical Realities, $2^{\text {nd }}$ ed., (New York and Oxford: Oxford University Press, 1984), 27.

${ }^{64}$ Catharine Beecher's A Treatise on Domestic Economy, was very popular. Published first in 1841, it underwent fifteen editions in the next twenty-eight years. In 1869 she published The American Woman's Home: or Principles of Domestic Science with her sister, Harriet Beecher Stowe. Both volumes urged standardization of American domestic practices and advocated that the values of the home apply to all aspects of national life.

65 Milton Bradley \& Co., Work and Play Annual, 3.
} 
presence of every member around the evening lamp in preference to any other places of amusements. ${ }^{66}$

The popular domestic advice manual The American Woman's Home: or, Principles of Domestic Science, published in 1869 weighed in on this subject too:

There are husbands and fathers who conscientiously subtract time from their business to spend at home, in reading with their wives and children, and in domestic amusements which at once refresh and improve. The children of such parents will grow up with a love of home and kindred which will be the greatest safeguard against future temptations, as well as the purest source of earthly enjoyment. ${ }^{67}$

A nation of virtuous citizens was the ideal that evangelical Protestants and secular writers of the nineteenth century hoped would be produced through moral influence. ${ }^{68}$ The first and foremost setting for that influence was the home headed by a woman who provided moral education for her family. The space in the home ideal for that instruction to take place was the parlor. Whereas the parlor in late eighteenth and early nineteenth centuries in the United States served the elite as a social space for sizeable groups of other well-to-do people, by the mid-nineteenth century, with the development of industrial capitalism and the rise of the middleclass, more citizens could afford parlors and they served the middle-class as social spaces for smaller domestic groups. ${ }^{69}$ The parlor became the badge of middle-class status, advertising that a family possessed the financial resources to set aside a

\footnotetext{
66 Ibid.

${ }^{67}$ Catharine E. Beecher and Harriet Beecher Stowe, The American Woman's Home: or, Principles of Domestic Science; Being A Guide to the Formation and Maintenance of Economical Healthful, Beautiful, and Christian Homes (New York: J.B. Ford and Company, 1869), 300.

${ }^{68}$ Rex Burns, Success in America: The Yeoman Dream and the Industrial Revolution (Amherst: University of Massachusetts Press, 1976), 8.

${ }^{69}$ Katherine C. Grier, Culture and Comfort: Parlor Making and Middle-Class Identity, 1850-1930 (Washington and London: Smithsonian Institution Press, 1988), 31.
} 
room for social ceremony and to furnish it for that purpose. ${ }^{70}$ The 1869 popular domestic advice book The American Woman's Home: or, Principles of Domestic Science by Catharine Beecher and Harriet Beecher Stowe defined "parlor" as a room "reserved for the reception-room of friends, and for our own dressed leisure hours." ${ }^{71}$ Henry T. Williams and Mrs. C. S. Jones, in Beautiful Homes. or, Hints in House Furnishing, an 1878 advice book on household decorating for new consumers, wrote that the middle-class parlor "served both as reception-room and that chosen apartment which in the olden times was the 'best-room' of our grandmothers."72 Since the parlor was the principal private room set aside to receive guests, it served as a transitional zone between public and private, accommodating both the domestic and cosmopolitan. The parlor was where public manners were on display, and therefore where guidance in proper behaviors was needed. ${ }^{73}$

The popular lithograph The Four Seasons of Life: Old Age (Currier and Ives, 1868) made visual the typical middle-class American parlor. The popular print constructed the parlor as a space of influence, unity, continuity, gender and status. (figure 2.3) All the elements considered to be essential to the parlor are present in this parlor: carpets, window draperies with lace curtains, a sofa and reception chairs, a center table, a decorated mantel, and framed pictures. ${ }^{74}$ The center table conforms to advice given in Beautiful Homes: "Scatter a few books and the latest

\footnotetext{
${ }^{70}$ Ibid, 64. The terms "parlor" and "drawing room" in the United States were interchangeable, although "drawing room" was a term seldom used.

${ }^{71}$ Beecher and Stowe, The American Woman's Home, 86.

${ }^{72}$ Henry T. Williams and Mrs. C. S. Jones, Beautiful Homes; or, Hints in House Furnishing (New York: Henry T. Williams, Publisher, 1878), 110.

${ }^{73}$ Russell Lynes, The Domesticated Americans (New York, Evanston, and London: Harper and Row, Publishers, 1963), 139.

${ }^{74}$ Grier, Culture and Comfort, 30.
} 
papers on table and sofa, and let them look as if they had been so interesting that they had been read." 75 Works of art hang on several of the walls of the parlor, including a landscape, a scene from classical mythology, and portraits of ancestors. According to the advice dispensed in the The American Woman's Home:

The educating influence of these works of art can hardly be overestimated. Surrounded by such suggestions of the beautiful, and such reminders of history and art, children are constantly trained to correctness of taste and refinement of thought, and stimulated sometimes to efforts at artistic imitation, always to the eager and intelligent inquiry about the scenes, the places, the incidents represented. ${ }^{76}$

The grandmother sits at the center table occupied with needlework, signaling her connection with the domestic world, the private sphere. A dainty basket of sewing occupies the bottom shelf of a stand as recommended in Beautiful Homes. ${ }^{77}$ The grandfather sits near the fire with a newspaper in his hand, a symbol of his connection with the wider world, the public sphere. The grandfather has paused in his reading to listen to his granddaughter, who sits at his feet, reading to him from a book open on her lap. Literacy and education is important in this scene. With the drapes and lace curtains pulled back, we can see through the window that the granddaughter's mother and father are dashing through the snow in a two horse open sleigh, about to make the family complete in the warmth of this parlor.

The Four Seasons of Life: Old Age situated the new concept for socializing children by domestic influence, in the parlor. The composition of this print, with the grandmother in the center, constructed domestic attention as the order and

75 Williams and Jones, Beautiful Homes, 111.

76 Beecher and Stowe, The American Woman's Home, 94.

77 Williams and Jones, Beautiful Homes, 111. 
experience of family life. This family modeled what Milton Bradley \& Co. advertised as the ideal occupation for a middle-class family: the presence of every family member around the evening lamp. An astral lamp, a technological improvement over the Argand lamp to improve light distribution and make evening entertainment easier to do, occupies the center table surface. ${ }^{78}$ Although books are scattered about on the surface of the center table, a common item is missing, the family Bible. Not only is it missing from the center table, it is closed and tucked away but still visible, on a stand in the corner of the parlor. If this scene was constructed to show the rule of patriarchal authority, the Bible would be open on the center table, the grandfather reading from it, and all other members seated around him creating a tableau of hierarchical power. Instead, in a tableau of domestic attention, the grandfather was placed in the composition to the left of center at the same level as the grandmother, and he was shown participating in family activities by pausing to listen to his granddaughter read to him.

By mid-century, "parlor pastimes" such as acting charades, parlor tricks, indoor games, and home amusements had become popular among middle-class families. ${ }^{79}$ Books such as The American Home Book of In-Door Games, Amusements and Occupations by Mrs. Caroline L. Smith ("Aunt Carrie"), and magazines such as Work and Play Annual of Home Amusements and Social Sports and Godey's Lady's

${ }^{78}$ Leroy Thwing, Flickering Flames: A History of Domestic Lighting through the Ages (Rutland, Vermont: Charles E. Tuttle Company, 1966), 76.

${ }^{79}$ The 1871-72 edition of Work and Play Annual of Home Amusements and Social Sports listed and described "parlor tricks" such as Spirit Rappings, The Black Art, The Magic Artist, What's O'Clock, Magic Music. The In-Door Games the magazine listed and described were "Verbatim," The Game of "Character," The Game of Proverbs, Natural History Game, The Scissors Game, The Knight of the Infanta, and Jack's Alive. 
Book and Magazine listed and described games that the directions assumed would be played in the parlor with children and adults, family and guests together. These games and activities often used objects to amuse, instruct and encourage conversation among children and adults. Beautiful Homes recommended that families, in their parlors, "Place boxes of games, scrapbooks and portfolios filled with pictures, photograph albums and objects of amusement, such as the stereoscope, kaleidoscope, and microscope, in appropriate places, and place chairs near them."80 The preface of The American Home Book of In-Door Games, Amusements, and Occupations informed the reader that the author chose games, amusements and occupations that would "carry to the home circle that spirit of enjoyment which is natural to the young heart, and which should not be absent from the more mature." 81 The book makes clear the games were also chosen for their usefulness in training the next generation of citizens of the nation. ${ }^{82}$

An ideal form that training could take was the parlor game The Checkered Game of Life, "and a few other equally good games" according to Work and Play Annual. ${ }^{83}$ According to Milton Bradley \& Co., The Checkered Game of Life

\footnotetext{
80 Williams and Jones, Beautiful Homes, 112.

${ }^{81}$ Mrs. Caroline L. Smith, The American Home Book of In-Door Games, Amusements, and Occupations. Boston: Lee and Shepard, Publishers, 1872), iii. 82 Ibid.

${ }^{83}$ Milton Bradley \& Co., Work and Play Annual, 37. Other games manufactured by Milton Bradley \& Co. and advertised in Work and Play Annual were: Monarchs and Thrones, "a new game of contemporary history;" Kriss Kringle's Christmas Tableaux, a moving diorama; The Game of Authors, a card game in which players test their knowledge of authors by trying to collect all the cards representing particular author's works to create "books;" The Game of What Is It, or The Way to Make Money, "invented to quicken those perceptions necessarily in use in ordinary business transaction;" The Smashed-up Locomotive, a puzzle and a "mechanical educator" for all the family who tries to put a locomotive and its tender back
} 
inaugurated "the introduction of moral and instructive games and amusements into our homes." 84 They made clear The Checkered Game of Life was not simply a game of chance "but in every move there is an opportunity for the exercise of the judgment." 85 "Parlor pastimes," therefore, were not just fun and entertaining but also had an underlying moral and instructional purpose. Game playing became a way to demonstrate that home and family was not cold and formal, and to learn the behaviors required of a role in the wider society. Because the parlor was the room reserved for the reception of guests and was usually off-limits to children in the family except for certain occasions, it was important that playing games help provide those occasions. ${ }^{86}$ The influential author Harriet Beecher Stowe, using the pen name of "Christopher Crowfield," weighed in on just this subject in her book of advice House and Home Papers, published in 1865:

If liberty in a house is a comfort to a husband, it is a necessity to children. When we say liberty, we do not mean license. We do not mean that Master Johnny be allowed to handle elegant volumes with bread-and-butter fingers, or practice line-drawing with a pin on varnished furniture. Still it is essential that the family-parlors be not too fine for the family to sit in, - too fine for the ordinary accidents, haps and mishaps, of reasonable well-trained children. The elegance of the parlor where papa and mamma sit and receive their friends should wear an inviting, not a hostile and bristly, aspect to little people. Its beauty and its order gradually form in the little mind a love of beauty and order, and the insensible carefulness of regard. ${ }^{87}$

together again; Miniature Panoramas "in which the subject is historical," for example the Historiscope; The Zoetrope, an instrument of animation; The Checkered Game of Life; etc.

84 Ibid.

${ }^{85}$ Milton Bradley \& Co., Work and Play Annual, 37.

${ }^{86}$ David P. Handlin, The American Home: Architecture and Society, 1815-1915 (Boston, Toronto: Little, Brown and Company, 1979), 354.

${ }^{87}$ Harriet Beecher Stowe [under the pseudonym Christopher Crowfield], House and Home Papers (Boston: Ticknor and Fields, 1865), 67-68. 
Playing games in the evening was an effective way to re-establish family unity in a time when each member of the family had separate functions. The parlor center table became the symbol of family unity. The landscape architect and popular writer of his time Andrew J. Downing wrote in The Architecture of Country Houses, published in 1850: "...the center table is to us the emblem of the family circle...." ${ }^{88}$ In The Art of Amusing, the noted cartoonist and humorist, Frank Bellew (1828-1888), who wrote for most of the notable publications of his time, noted: "In the first place, we must remark, in a general way, that we like a large centre-table. It is something to rally round, it is handy to put things on, and convenient for the bashful to lean against." ${ }^{89}$ The parlor center table was the perfect surface for placing a board game like The Checkered Game of Life.

\section{History of The Checkered Game of Life}

The game producer and entrepreneur Milton Bradley (1836-1911) utilized the skills required to succeed in an industrial capitalist economic system when he took advantage of a good opportunity by buying The Checkered Game of Life from an inventor. ${ }^{90}$ Already owning a lithography factory, he knew he could chromolithograph and package the games in his own plant, and sell them in New York City, taking advantage of the proximity of the city's sales network, railroad

${ }^{88}$ Andrew Jackson Downing, The Architecture of Country Houses, Vol. II, originally printed in1850 (New York: Da Capo Press Reprint Edition, 1968), 429.

${ }^{89}$ Frank Bellew, The Art of Amusing: Being a Collection of Graceful Arts, Merry Games, Odd Tricks, Curious Puzzles, and New Charades. Together with suggestions for private theatricals, tableaux, and all sorts of parlor and family amusements (New York: Carleton, Publisher. London: S. Low, Son and Co., 1866), 11. ${ }^{90}$ James J. Shea, Jr., "The Milton Bradley Story," Newcomen Society in North America, Addresses 636-654 (November 2, 1972): 10. 
system, steamships, canal system, postal service, and advertising network. He used the same impressive mechanism of generation and dissemination used for mass amounts of printed material for evangelical Christian organizations at this same time, such as the American Tract Society, the American Bible Society, and the American Sunday School Union. By the end of 1860, the company fortunes looked bright with the sale of 45,000 copies. ${ }^{91}$

When the war broke out the next year, the company seized the opportunity to supply The Checkered Game of Life as a portable game to soldiers with nothing to do during long periods of enforced downtime. Called "Games for Soldiers," the box contained nine games made of chromolithographed pasteboard (The Checkered Game of Life, Backgammon, chess, checkers, and five varieties of dominoes) and was small enough to fit in a pocket or knapsack. The advertisement in the December 10, 1864 issue of Scientific American states "All put up in a small box weighing but five ounces. Just the thing to send to the boys in CAMP or HOSPITAL for a CHRISTMAS PRESENT, or to keep at home for the winter evenings."92 "Games for Soldiers" was sold throughout the war in New York, Boston and other outlets that sold the bigger version of The Checkered Game of Life, and was bought in large quantities by charitable organizations such as the U.S. Sanitary Commission for distribution in the Union Army. ${ }^{93}$ Such action resulted in the accumulation of profits by the company

\footnotetext{
${ }^{91}$ Shea, Jr., "The Milton Bradley Story," 10.

${ }^{92}$ Advertisement, Scientific American XI, no. 24 (Dec. 10, 1864): 383. Emphasis present in the original advertisement.

${ }_{93}$ Shea, It's All in the Game, 70.
} 
that further facilitated its reorganization and relocation to larger quarters by $1864 . .^{94}$

Description of The Checkered Game of Life

The game board, accessories and box are all constructed from what was a new industrial product in 1860, pasteboard, and decorated in an attention grabbing way with a new industrial process, chromolithography. (figure 2.2)

Chromolithography allowed the company to utilize a cost effective color print technique to make their game stand out in an otherwise black and white world. Therefore, in manufacturing the game and its container, the company employed red to catch and hold the customer's attention. ${ }^{95}$ The name of the game appears on the box attractively embellished with colorful decoration; the design also includes the company’s logo “Milton Bradley \& Co. Springfield, Mass.”

The visual design of The Checkered Game of Life links this game played on the Civil War battlefield with the domestic space, connecting the public and private spheres. The game board is a checkerboard. Overall, the dimensions are 14 5/8 inches by $145 / 8$ inches, made up of sixty-four squares configured as eight rows and eight columns enclosed within a black border. (refer to figure 1.2) Every other square is a neutral space and has a background of red with a star motif in the center of a quatrefoil design in white to make the combined design pop. This design would have reminded the period viewer of quilt patterns. The alternating squares hold pictures, writing and/or numbers in black with the natural color of the paper as

${ }^{94}$ Shea, It's All in the Game, 76.

95 Ibid, 49. 
background, and make up the directions for play action. The orientation of the board is made clear because left and right, top and bottom are placed along the borders of the frame.

\section{Description of The Checkered Game of Life play action}

In The Checkered Game of Life, all the actions a player makes take place in the wider world of society with players working as virtuous citizens of the nation in order to win the game. Every player starts the game at the bottom, left corner of the board, in the private sphere in the cradle of INFANCY, but their first move launches them into the public sphere. For example, a player can move from INFANCY to SCHOOL which immediately sends the player to COLLEGE, and the player gains five points, launching him into society and the economy. As players journey through life in the public sphere, they can act BRAVELY and win HONOR (and five points), use HONESTY to gain HAPPINESS (and five points), use PERSEVERANCE to win SUCCESS (and five points), apply INFLUENCE to win a FAT OFFICE (and five points), go into POLITICS to win a seat in CONGRESS (and five points), or apply INDUSTRY to gain WEALTH (and ten points!) But there are hazards. The game board is littered with vices such as GAMBLING which sends a player to RUIN, INTEMPERANCE results in POVERTY, IDLENESS results in DISGRACE and a set back almost to the beginning of the game, CRIME sends a player directly to PRISON and a loss of a turn. But the worst hazard is SUICIDE; the player who lands there is thrown out of the game. 
The goal of The Checkered Game of Life is to accumulate, before anyone else, one hundred points of virtues, which required a player to live their game life the most virtuously. The directions state: "Whenever any player moves on to a square bearing a number, he gains the amount of that number, which he must score on his record dial. The one obtaining 100 first, wins the game."96 Only virtues (SCHOOL, INFLUENCE, HONESTY, INDUSTRY, BRAVERY, POLITICS, and PERSEVERANCE) are rewarded by sending a player to a square with points (COLLEGE, FAT OFFICE, HAPPINESS, WEALTH, HONOR, CONGRESS, and SUCCESS.) The virtuous life was the successful life. HAPPY OLD AGE, worth fifty points, is located in the upper right corner of the game board but no virtue sends a player there. However, the directions exhort players to "always strive to advance" and "the best course [a player] can select, [is] striving to gain on his journey that which shall make him the most prosperous, and to shun that which will retard him in his progress." ${ }^{\prime 97}$ The only way a player could do this was to exercise all the skill and judgment they possessed to continually land on virtues, or HAPPY OLD AGE. The directions suggest that even though HAPPY OLD AGE is worth fifty points, as it "is surrounded by many difficulties, 50 may oftentimes be gained as soon by a succession of smaller numbers as by striving for Happy Old Age."98

The vignettes that illustrate virtues and vices in The Checkered Game of Life borrowed a style commonly used by the American Tract Society to directly address

\footnotetext{
${ }^{96}$ Milton Bradley \& Company, "The Checkered Game of Life - Rules of the Game," in The Checkered Game of Life (Springfield, Massachusetts: Milton Bradley \& Co., 1860), 2.

${ }^{97}$ Milton Bradley \& Company, "The Checkered Game of Life - Rules of the Game," 1. 98 Ibid, 3.
} 
the themes that defined their work in the American evangelical Protestant movement. The American Tract Society (ATS) was established in New York City in 1825. It is an important evangelical Protestant benevolent association, one of the largest, best organized and longest lived. ${ }^{99}$ It was established during the Second Great Awakening (1800-1870) to preserve the Protestant Christian character of the nation through moral influence, at a time when religion had been disestablished in the newly formed nation. The purpose of the ATS in this quest for moral influence was to publish and disseminate tracts of Protestant literature through mass amounts of ephemeral illustrated printed materials, like the Christian Almanac, pamphlets, books, picture books, primers, and newsletters. The vignettes illustrated many of the themes that defined the work of the Tract Society, such as temperance, opposition to gambling, industriousness, literacy, and the importance of family. However, directly religious themes that defined their work such as church attendance, practice of prayer, regular reading of scripture, do not appear on the game board. The style of the vignettes in The Checkered Game of Life called on the plain programmatic style used in American Tract Society publications in the $1820 \mathrm{~s}$ and ' 30 s and beyond. The style was best suited for instruction where making the message clear was important. Features of this style manifested in the game vignettes are the stark black and white contrast, conformance to the square format of the checkerboard design of the game, and labels in which text and image

${ }_{99}^{9}$ Morgan, Protestants and Pictures, 71. The ATS still operates in 2020. It relocated to Garland, Texas in 1978 and continues to produce tracts, believing its mission and messages continue to be relevant today. 
correspond completely. Like ATS publications, the moral tone of the vignettes in the game counseled self-denial and restraint. ${ }^{100}$

The teetotum and the record dial

Milton Bradley \& Company connected playing the parlor game The Checkered Game of Life with living life. The opening paragraph of the directions to the game states: "This game represents, as indicated by the name, the checkered journey of life, and is intended to present the various vices and virtues in their natural relation to each other.... The journey of life is governed by a combination of chance and judgment...."101 Players journeyed through life by the spin of a teetotum. (figure 2.4) The directions describe how to use the teetotum and what it is: "Also with a teetotum having six sides, each side numbered, and the number which is uppermost, after being twirled, denotes what move the player shall have, according to the description of moves on the record dial cards. The teetotum is composed of a card and wooden pin, which being inserted in the card, forms a top."102 The teetotum created the element of chance in the player's journey through life, but the directions caution: “...chance represent[s] the circumstances in life over which we apparently have no control, but which are nevertheless governed to a great extent by the voluntary actions of our past lives." 103

\footnotetext{
100 Morgan, Protestants and Pictures, 73.

101 Bradley \& Co., "The Checkered Game of Life - Rules of the Game," 1. 102 Ibid, 2.

103 Ibid, 1. Because the teetotum represented chance, many scholars have pointed out, erroneously I think, that a teetotum was included in The Checkered Game of Life in order to avoid including dice, considered to be the "devil's tools" because of their connection to gambling. I don't agree. In the write-up for The Checkered
} 
The record dial introduced the element of choice. (figure 2.5) The directions summarize this: "So in the game, the player oftentimes has choice of a number of moves which he can make to more or less apparent advantage...."104 A technological innovation in the world of games, the record dial demands that players conceive of play action in two-dimensions. Along with allowing players to keep track of accumulating points during play action with a rotary pointer and a semi-circle of increasing numbers, the record dial translates the number spun on the teetotum. The translation on the record dial introduces choice by including a list of conversions for the numbers spun on the six-sided teetotum, creating choices in both direction and number of moves. A one spun on the teetotum gives the player the right to choose to move one square up or down; a two, to choose to move one square right or left; a three, to choose to move one square diagonally in one of four directions. Spinning a four, five or six on the teetotum gives the player the right to make two choices, to move one or two squares up or down, left or right, or diagonally in one of four directions.

Tension was embodied in the play action of the game which called for choosing virtuous behaviors in the journey through life, values taught in the domestic world, but this required competitive strategies in order to be the first to accumulate one hundred points, involving a different set of values taught in the

Game of Life on page 37 of Work and Play Annual of Home Amusements and Social Sports from 1871-72, Milton Bradley \& Co. described a de-luxe version of the game as containing dice: "The large edition in muslin and gilt is elegant, and is supplied with dice and cups instead of the teetotum, designed more especially for adults ...." The decision to include a teetotum made of pasteboard and wood in the original version was probably made based on practical, cost-saving business considerations. 104 Bradley \& Co., "The Checkered Game of Life - Rules of the Game," 1. 
business world. It is the inclusion of the element of choice that allows a player to develop those competitive strategies to win. Choice, then, ensured individual action gets rewarded. One strategy is to make a beeline for the opposite corner of the game board from INFANCY to HAPPY OLD AGE because it is worth a whopping fifty points! On a player's way there, if he lands on the space of an opponent, so much the better; such a move sends the opponent to jail, back almost to the beginning of the game.

The Mansion of Happiness

Play action that included the element of choice in The Checkered Game of Life was remarkably different than any other game invented in the first half of the1800s. The Checkered Game of Life was not a typical race game like the earlier popular game The Mansion of Happiness, first published in Britain in 1800 and subsequently published, with minor alterations, in the United States by W. and S.B. Ives Company of Salem, Massachusetts in $1843 .{ }^{105}$ (figure 2.6) Play action for The Mansion of

105 Two alterations in the American version of Mansions of Happiness involve substitutions of the names on two punishment squares. American audiences would not have know what Newgate in the British version meant so it was changed to Prison, and Bridewell was changed to House of Corrections. Also, the American version of the game gave players a second chance to attain the Mansion of Happiness. The British original version sends players back to the start of the game if they spin over the number necessary to land at the Mansion, but the American version allows one more try. This necessitated the addition of a square, the Seat of Expectation, for a player to "hang-out" if they spun over, seven spaces away from the Mansion. The American version allows players one more try before, if they roll over, they must return to start the game over. In the British version, the Mansion of Happiness is placed in the center of the game board under a royal crown and is titled "Oatlands," a royal palace occupied at the time the game was published by the Duke and Duchess of York. In the American version, the Mansion is placed under the outstretched wings of an eagle. 
Happiness is entirely determined by chance, the spin of the teetotum. The game board is designed as an oval spiral of sixty-seven spaces. The heart of the spiral is the destination of players, illustrated as a lush garden with four dancing women playing classical instruments with classical edifices in a misty background. An eagle perches on the top border of the picture with a red banner in its beak that proclaims “The Mansion of Happiness."

The Mansion of Happiness constructed life as a race to heaven with the rules stacked against the players. The goal of the game is to land on the Mansion of Happiness in the center of the game board. Inspired by the biblical verse in the Gospel of John 14:2 “In my Father's house are many mansions....", The Mansion of Happiness symbolizes heaven. Some of the sixty-seven spaces are green blank neutral squares and others contain colorful illustrations of virtues and vices. Although there are an equal number of vices and virtues (thirteen), the consequences of landing on most vices hinders your progress to the Mansion of Happiness more than landing on a virtue advances your progress toward that goal. This is because all virtues are treated equally; landing on PIETY, HONESTY, TEMPERANCE, GRATITUDE, PRUDENCE, TRUTH, CHASTITY, INSINCERITY, HUMILITY, INDUSTRY, CHARITY, HUMANITY, or GENEROSITY entitles a player "to advance six towards the Mansion of Happiness."106

There are so many pitfalls of vice blocking a player's journey to heaven that it is hard to finish the game. Landing on the vices AUDACITY, CRUELTY, IMMODESTY,

106 W. \& S. B. Ives, "The Mansion of Happiness Explanation of the game and Rules of the Game," The Mansion of Happiness (Salem, Massachusetts: W. \& S. B. Ives, 1843), one sheet. 
or INGRATITUDE requires the player to return "to his former situation till his turn comes to spin again, and not even think of Happiness much less partake of it."107 So essentially, a player who lands on one of these four vices, loses a turn in forward progress. However, the consequences for landing on other vices are more serious. For example, whoever lands on SABBATH BREAKER "must be taken to the WHIPPING POST [losing six spaces of forward progress] and whipt, and pay a fine of one." DRUNKENNESS sends a player to the STOCKS (lose 7 spaces) and SUMMIT OF DISSIPATION to RUIN (lose 8 spaces) and a fine of three counters. Especially egregious are landing on A CHEAT or ROBBER, the consequences of which involve not only losing a turn and paying a fine, but starting the game over. For A CHEAT that means losing thirty-four spaces of forward progress, but for ROBBER it means losing fifty-seven spaces!

The play action associated with The Mansion of Happiness game belongs to a Calvinist worldview that envisioned a closed and predetermined universe of certainty indifferent to temporal moral distinctions. ${ }^{108}$ Calvinists were duty bound to work for the glory of God and this required enough independence to "worship

\footnotetext{
107 W. \& S. B. Ives, "The Mansion of Happiness Explanation of the game and Rules of the Game," one sheet. Emphasis included from the directions.

108 Louis Menand, The Metaphysical Club (New York: Farrar, Straus and Giroux, 2001), 88. Calvinism is a Reformed Protestant movement in which converts believed God's word was only revealed through Christ, the guilt of sin was inherited from Adam and Eve so that everyone lacked the ability to avoid sin, and God unconditionally predestined some to be saved from that sin and others to eternal damnation. The cultural system that prevailed commanded followers to do as they were told and nothing they did could change the outcome. But every Calvinist was commanded to prove their potential election to themselves and their peers by leading lives of worship through action, which meant lives of endeavor fruitful for themselves, their community and their God. The purpose of fruitfulness was to reflect the glory of God, the real owner of material things.
} 
through action."109 Therefore, each player in The Mansion of Happiness moved independently. Landing on any of thirteen virtues demonstrated the free and unearned favor of God, but since the favor (move ahead six spaces toward personal salvation) was unearned, all received the same reward. But a player who landed on vices had succumbed to the sin of self-interest, and punishment was swift, reversing forward progress toward personal salvation, sometimes severely depending on the vice. The player who landed on the least number of vices made it to The Mansion of Happiness first and won.

The Mansion of Happiness game visualized the world it represented. The very design of the game, a spiral folding in on itself with no way out, illustrated a world that was closed. ${ }^{110}$ The Mansion of Happiness required players to do, not to think. This is not a game that involves choice or strategy. Players had no control over whether they ultimately achieved salvation (landed in heaven) since they had no individual agency. Players were instead at the mercy of the spin of the teetotum and did whatever they were told to do by the rules, just as worshippers were expected to attend church and were told by the preacher what to do. The outcome was certain, only what player would arrive at The Mansion of Happiness first was in question.

In the colorfully illustrated spaces of the game, both men and women illuminate virtues and vices according to constructed gender bias of the time, with both the public sphere and the private sphere intermixed on the game board.

109 Menand, The Metaphysical Club, 88.

110 Yonan, "Toward a Fusion of Art History and Material Culture Studies," 110. 
Women illuminate more virtues than men do: of the thirteen virtues illustrated, ten are illustrated with women: Piety, Gratitude, Prudence, Chastity, Humility, Charity, Temperance, domestic Industry, and Justice and Truth as allegorical figures. These virtues were associated with the private sphere. Men illuminate more vices; of the thirteen vices illustrated, eight are illustrated by men: Passion, Cruelty, Sabbath Breaker, Perjurer, Robber, Summit of Dissipation, Drunkard, and Ingratitude. These vices were associated with the public sphere. The illustration of the Mansion of Happiness, of only women making music in a garden setting, connects women to nature and the spiritual. However, appearing above heaven is the illustration of a flying eagle, symbol of strength and patriarchal authority.

\section{A cultural interpretation of The Checkered Game of Life}

The Checkered Game of Life revealed a change in worldview. The Mansion of Happiness constructed a world of certainty, whereas The Checkered Game of Life constructed a world of uncertainty. In the Mansion of Happiness, every player worked to make it to heaven and had to move along the same road to achieve it, and every player was affected the same way by every vice and virtue they landed on. Therefore, the play action constructed the successful life as one devoted to heavenly concerns. Although The Checkered Game of Life also used virtues and vices to facilitate or retard progress toward success, the successful life was not defined in religious terms, but as the player who lived his life most virtuously. The game got rid of heaven and gave players more control. The play action in The Checkered 
Game of Life neither predetermined how a player would accumulate points, nor even whether they would ever need to reach Happy Old Age to win.

The Checkered Game of Life required players to do and think. The game introduced choice to ensure individual agency and participation got rewarded. Milton Bradley and Co. did away with the race game format where play action was controlled only by chance and instead borrowed the ideas of the chessboard with its checkerboard design and the movement of the game pieces up or down, right or left, or diagonally in either of four directions. The checkerboard construction, and the addition of choice in movement facilitated player agency that made the outcome far from a foregone conclusion. This play action drew on the ideas of a new worldview informed by capitalism that facilitated human agency and viewed moral action as that course of action taken when another could have been chosen. The old world philosophy denied human agency and therefore the foundation for morality. 111

The encouragement of individual agency and participation in The Checkered Game of Life allowed players to form ideas and develop strategies to win the game of life. These ideas were dependent on the players and their changing circumstances with each spin of the teetotum and each move they chose to make. The directions to The Checkered Game of Life state: "many ideas are suggested by the peculiar arrangement of the several squares" in the play action of the game. ${ }^{112}$ Strategies were encouraged in the game because these ideas created a better life, personally with wealth, happiness, and success, and socially, with matrimony, and happy old age. The game, therefore, constructed ideas as mutable, as "provisional

111 Menand, The Metaphysical Club, 247.

112 Bradley \& Co., "The Checkered Game of Life - Rules of the Game," 2. 
responses to the particular and unreproducible circumstances" of the ever-changing play action. ${ }^{113}$ This was a modern way of thinking about ideas. Players used ideas this way because choice facilitated the movement demanded in an industrial, capitalist society that thrived on constant upheaval. The player who won The Checkered Game of Life was the player who made the most of the opportunities given him. ${ }^{114}$

Independence in The Mansion of Happiness gives way to individualism in The Checkered Game of Life. To facilitate the change in the construction of success demanded by the new economic system, The Checkered Game of Life facilitated the freedom of players to pursue their own welfare. One way this was facilitated was by removing the many vices encountered in a game like The Mansion of Happiness, such as PASSION, CHEAT, AUDACITY, CRUELTY, IMMODESTY, INGRATITUDE and getting rid of overt connections to religion such as SABBATH BREAKER, resulting in streamlined play. The individual action facilitated in The Checkered Game of Life could be expressed as virtuous self-denial, through HONESTY, PERSEVERANCE, INDUSTRY, or BRAVERY or "cavalier individualism" through INTEMPERANCE, IDLENESS, GAMBLING, or CRIME. ${ }^{115}$ However, it was only actions that showed selfsacrifice that earned players points, so it was only through living a virtuous life that one could be successful. A typical visual image of this theme can be seen in the 1835 broadside The Life and Age of Man: Stages of Man's Life from the Cradle to the Grave,

\footnotetext{
113 Menand, The Metaphysical Club, xii.

${ }^{114}$ Kathleen Pyne, Art and the Higher Life: Painting and Evolutionary Thought in Late $19^{\text {th }}$ Century America (Austin: University of Texas Press, 1996), 36.

115 Ryan, Cradle of the Middle Class, 231.
} 
wherein all Christians may behold their frail nature and the miseries that attend a sinful life, by Albert Alden. (figure 2.7)

To foster the proper attitudes and behaviors of morality, the proper environment and training were needed. That proper environment was the private sphere, the home with a mother nurturing and training a family. Therefore, women do not appear on The Checkered Game of Life game board. They worked behind the scenes to influence moral character. But they played The Checkered Game of Life to help maintain those values since the public realm was believed to do everything it could to coerce citizens to intemperance, gambling, crime, even suicide. We see this visualized in the 1846 Nathaniel Currier lithograph The Drunkard's Progress: From First Glass to Grave. (figure 2.8)

The absence of women pictured on the game board of The Checkered Game of Life, quite unlike The Mansion of Happiness where both men and women appear, reveals a shift in the social system in America to accommodate an industrial capitalist economic system. The older corporate farm and artisan economy based on production, domestic division of labor and generational continuity, under which Calvinism thrived, bound its members together to make a living. The family's economic unity was expressed at the point of production. Therefore, a game with this older worldview, like The Mansion of Happiness, intermixes men and women, public sphere and private sphere. In the industrial age represented by The Checkered Game of Life, members of families had different jobs, workplaces, and economic roles. The family's economic unity was expressed at the point of consumption. The place of residence (private sphere) and the place of work (public 
sphere) were separate, but the household still had an important economic function. ${ }^{116}$ The mother became the head of the household by organizing consumption. She raised the children, took care of the husband who worked outside the household. Therefore, women disappeared from the game board in The Checkered Game of Life to fulfill their role of moral influence.

Evangelical Protestant benevolent associations' literature preached that greater moral influence was needed through virtuous self-denial. However, the object of this moral influence was just as much self-definition as social influence. The visual rhetoric during the 1850 s and 1860 s constructed the middle-class family as the center of order. ${ }^{117}$ For example, in The Checkered Game of life, CUPID sends players to a square with a vignette that describes a church setting that includes a man, and a woman wearing a white gown, standing together with two witnesses in front of a preacher who has his arm outstretched in blessing, labeled MATRIMONY. Therefore, playing parlor games within the family helped form the parameters of middle-class behavior: absence of conspicuous display of wealth, absence of behaviors like sloth, intemperance, unbelief, illiteracy. Instead, the middle-class exercised self-denial in an age of individualism and materialism. ${ }^{118}$

Like some writers of the time, The Checkered Game of Life called on society to use self-denial to guide behavior in both the private and public sphere. Many American writers of the time, for example the theologian who broke away from Calvinism Horace Bushnell, the long time editor of Godey's Lady's Book Sarah

\footnotetext{
116 Ryan, Cradle of the Middle Class, 231.

117 Morgan, Protestants and Pictures, 108.

118 Ibid.
} 
Josepha Hale, Harriet Beecher Stowe and Catherine Beecher believed the values of the home (the private sphere) stood in opposition to values in the public sphere. However both Bushnell and Hale believed this divide was basic and enduring, and promoted an ideology of domesticity to compensate for a society obsessed with the pursuit of wealth. Their ideas separated private and public spheres to allow men to continue their pursuit of wealth in order to promote the growth of the economy, leaving women to concentrate on their moral role so that that growth would not be morally objectionable. ${ }^{119}$ Catharine Beecher, on the other hand, wanted domestic values to apply to both spheres. She called for women to eliminate the contradictions between the values of home and the outside world.

The Checkered Game of Life eliminated the contradictions between values of home and the outside world. The play action of The Checkered Game of Life eliminated this contradiction by beginning in the private sphere at the cradle of Infancy, then launched the player out into the public sphere where all the play action of the game occurs and where the only way to win is to lead a virtuous game life. This elimination of differences between manners in the private and public sphere in The Checkered Game of Life called for standardization of manners and attitudes so there would be one code to apply in society for all Americans. Catherine Beecher stated this in her very popular and influential domestic manual, $A$ Treatise of Domestic Economy.

Now the principles of democracy require, that the same courtesy which we accord to our own circle, shall be extended to every class and condition, and that distinction, of superiority and subordination shall depend, not on accidents of birth, fortune, or occupation but

119 Sklar, Catharine Beecher, 163. 
solely on those relations, which the good of all classes equally require." 120

"And if good-manners are the outward exhibition of the democratic fundamental principle of impartial benevolence and equal rights, surely the nation that adopts this rule, both in social and civil life, is the most likely to secure the desirable exterior. The aristocrat, by his principles, extends the exterior of impartial benevolence, to his own class only; the democratic principle requires it be extended to all.121

Catharine Beecher's views shaped an ideology of domesticity that proposed to unify the nation. ${ }^{122}$ Home was the perfect vehicle for national unity because it was a universally experienced institution recognizing no economic, political or regional boundaries. Capitalism fostered mobility and "equality" in America, but this precipitated the loss of traditional social identity. Therefore, the domestic experience could become the focus for a national identity. ${ }^{123}$ A columnist, H.M.T.C., in the April 1870 issue of Godey's Lady's Book and Magazine entitled "A Home Picture" echoes these ideas:

...the character of the mother moulds [sic] the individual, that "like mother like child," etc. But do we take in the full scope of woman's influence upon all the relations of society? Do we realize how thoroughly taste, morals, intellect, politics, religion are moulded [sic] by her forming hand? The homes of a nation are in her keeping, the children are as the workmanship of her hand, society takes color from her character. ${ }^{124}$

The Checkered Game of Life situated self-denial as a means of social cohesion, not personal salvation. Self-denial became the ideological basis for a

${ }^{120}$ Catharine Beecher, $A$ Treatise On Domestic Economy, 1841 edition (New York: Schocken Books, 1977), 124.

${ }^{121}$ Ibid, 132.

122 Sklar, Catharine Beecher, 158.

123 Ibid.

${ }^{124}$ H.M.T.C., “A Home Picture," Godey's Lady's Book and Magazine LXXX (April 1870): 354. 
national morality. Since self-denial was a middle-class attribute, The Checkered Game of Life became a purveyor of middle-class values: the absence of conspicuous consumption, the absence of behaviors like idleness, intemperance, crime, and gambling, and the presence of industry, education, bravery, perseverance, and honesty. ${ }^{125}$ The Checkered Game of Life worked to shape the character of the whole nation, a nation with common middle-class moral principles. ${ }^{126}$

The placement of punishments in The Checkered Game of Life revealed a liberal Protestant mindset in which social progress was considered an essential component in the education of Americans. On the game board, POVERTY and DISGRACE are located near the cradle of INFANCY. The directions state: "Now in starting life it is not necessarily a fact that poverty will be a disadvantage, so in the game it causes the player no loss to pass through poverty; ... The same of disgrace; a person may in early life be in disgrace for a time, through no fault of his own;"127 Also, the game board of The Checkered Game of Life constructed FAME and TRUTH as unreliable and untrustworthy. AMBITION led to FAME, but FAME carried no points and moved a player no further ahead toward his goal. AMBITION was not a virtue. TRUTH appears on the board singly and without points: no virtue sends a player to TRUTH. It does not aid a player in achieving his goal either. In the conservative evangelical Protestant worldview, locating moral agency in the individual led to the attitude that a person who was successful was good, and a person who was failing was bad. Failure was considered by conservatives to be that

125 Sklar, Catharine Beecher, 161; Morgan, Protestants and Pictures, 108. ${ }^{126}$ Sklar, Catharine Beecher, 161.

127 Bradley \& Co., "The Checkered Game of Life - Rules of the Game," 1. 
person's fault. However, the game was constructed to make the point that even in a world where people were free to choose, there were things beyond a person's control. Some people were given better chances than others, and some people were handed disadvantages through no fault of their own.

The individual agency and participation that trained citizens in virtuousness also created a "can-do" mentality that led to reform. ${ }^{128}$ Revealing a further shift away from more conservative evangelical thinking, a change in the design of The Checkered Game of Life from 1860 to 1866 moved this parlor game from a tool of influence to a tool of reform. ${ }^{129}$ The first version (1860) of this game contained a square called SPECULATION. Mimicking the volatile marketplace of nineteenthcentury America, landing on this square required an extra gamble with the odds stacked against the player, since he had to spin the teetotum again; a three or six sent a player directly to WEALTH for ten points, a good return on the player's investment, but a 1, 2, 4, or 5 resulted in RUIN. Luck was not in a player's favor because he had only a 1 in 3 chance of spinning a number that would result in personal gain instead of RUIN. The playing field wasn't level in this instance and it was beyond a player's control. In the 1866 version of the game, Milton Bradley substituted GOVERNMENT CONTRACT for SPECULATION. GOVERNMENT CONTRACT automatically sent a player to WEALTH to earn ten points and a position much closer to the fifty points of HAPPY OLD AGE. GOVERNMENT CONTRACT led immediately to personal gain. This particular playing field had been leveled.

${ }^{128}$ Cremin, American Education, 495.

129 Morgan, Protestants and Pictures, 20. 
The Checkered Game of Life connected virtue with success, but tried to ameliorate the effects of an uneven playing field. The Checkered Game of Life underwent changes in its design that reveal a move to counteract the forces of chance. Milton Bradley was very active in the Kindergarten movement, a movement that was all about leveling the playing field. He printed a monthly journal, the Kindergarten Review, and wrote an essay for one of the issues in which he stated he is most proud of his "educational inventions" which earned him no money. Milton Bradley echoed these ideas of reform when he wrote decades later in the 1890s: "In using the word success, I do not wish to confine its meaning to that cheap interpretation which sees only the glitter of gold or the glamour of elusive fame. In my case, I cannot overestimate the feeling of satisfaction which has been with me all these years at the thought that I have done something, if only something prosaic in character, to place the kindergarten on its present solid foundation."130 Education, a cornerstone of middle-class values, could level the playing field, for example through the Kindergarten movement.

Present in the play action on the game board of The Checkered Game of Life, tension animated the game. Because individual agency and participation encouraged the ability to develop strategies for getting ahead (winning), the game was exciting to play and was therefore popular. It brought together choice (requires you to make lots of decisions) and chance, and in this game life was NOT a journey along a fixed path as it was in The Mansion of Happiness. The Mansion of Happiness was a race to heaven, but only God controlled whether a player made it there. Some

${ }^{130}$ Shea, It's All in the Game, 180. 
scholars have written that The Checkered Game of Life was merely a race to accumulate the most points fastest. Accumulate or perish!131 But the play action was much more complicated than that. Although The Checkered Game of Life taught virtue as the path to personal prosperity, because the play action on the game board occurred in the public sphere, it also defined middle-class values and taught participation in a wider community as a path to national prosperity. By promoting a sense of community with common goals, The Checkered Game of Life promoted national unity.

\section{Conclusion}

Bradley made The Checkered Game of Life into the story of America. His new game did away with old religious ideas of predestination and certainty, substituting new ideas that allowed for individualism consistent with capitalism. However, there were rules over which a player had no control, and there were unforeseen consequences of past moves. Milton Bradley \& Co. therefore produced a game about the bumpy road to prosperity achieved through living by virtues such as industry, honesty, bravery and perseverance, a very popular American literary motif. For example, Benjamin Franklin's life was the story of a voyage "from the Poverty and Obscurity in which I was born and bred, to a state of affluence and some degree of Reputation in the World." ${ }^{132}$ He achieved Happy Old Age! Horatio Alger Jr.'s novels form a series of "rags-to-riches" stories that peaked in popularity in 1868. Bradley

131 Jill Lepore, Mansions of Happiness: A History of Life and Death (New York: Alfred A. Knopf, 2012), xxvii.

${ }^{132}$ Lepore, Mansions of Happiness, xxviii. From Benjamin Franklin, Autobiography, ed. J.A. Leo Lemay and P.M. Zall (New York: Norton, 1986). 
himself moved from "rags-to-riches" complete with many bumps in his life journey. The Checkered Game of Life nurtured the development of a virtuous citizenry to ensure national prosperity through moral order and civil liberties. ${ }^{133}$

A board game, The Checkered Game of Life, played in the parlor, the epicenter of family life and transition zone between the public and private sphere, was designed and packaged by Milton Bradley \& Co. to shape personal character. According to the influential Protestant preacher and writer, Horace Bushnell, character was slowly formed in an organic process of nurturing (as opposed to the inorganic process of conversion in Calvinist thinking) within the family, especially by the mother. ${ }^{134}$ This task was not accomplished through conscious teaching, but instead through planting seeds and nurturing them to promote the growth of an individual's character. ${ }^{135}$ This idea was given visual form in Nathaniel Currier's hand colored lithograph from 1849, The Tree of Temperance. (figure 2.9) The very form of the design, a tree, illustrates perfectly the idea of nurturing children to live virtuous lives as a process like planting a seed and encouraging it to grow. ${ }^{136}$ The unconscious process of "formation" replaced the conscious process of instruction.

However, the process of character formation carried with it specific gender, "race," religious, class, and national identities that depended on the prevailing cultural constructs of mid-nineteenth-century America. There were specific gender and class identities at work in purchasing and playing parlor games. Playing the game reunited the middle-class family at the end of a day of disparate activities, and

133 Morgan, Protestants and Pictures, 59.

134 Morgan, Protestants and Pictures, 271.

135 Ibid, 273.

136 Yonan, "Toward a Fusion of Art History and Material Culture Studies," 110. 
the location for that reunion was the domestic sphere, enforced by a political order that placed women in the parlor in charge of purchasing for and nurturing the family. Nurturing using The Checkered Game of Life made the game a site where the mother could facilitate a person's experience with domestic life and relationships with children, parents and siblings. Game playing then became an occasion for domestic bonding and this allowed for the message of the game to be learned. ${ }^{137}$

National character was shaped in the same way as personal character. Character implied something permanent, grounded and rooted in family, a shared history resistant to change, dependent on oral communication, creating a sense of shared community. ${ }^{138}$ Within the American nation, many institutions played a part in shaping the national character: families, churches, school, colleges, newspapers, magazines, textbooks, novels, history books, visual images and art, voluntary associations, laws, material culture like parlor games. ${ }^{139}$ The French political philosopher of the eighteenth century, Montesquieu, wrote that the laws of education within a society must be related to the form of government. Whereas monarchies needed education to status so that everyone knew their proper place in the social order, republics needed education to virtue to ensure citizens chose public over private interest. But this left open the questions what did "virtue" and "education" mean?

The Checkered Game of Life spelled out what those national virtues were, and located the communication of that message in the act of playing a game in the

137 Morgan, Protestants and Pictures, 274.

${ }_{138}$ Anderson, Imagined Communities, 6.

139 Cremin, American Education, 2. 
family parlor under the watchful eye of the mother. Milton Bradley \& Co. designed a game that conformed well to the model of moral influence active in Victorian middle-class families in the 1860 s, and by doing this, conflated a mass produced product of the industrial age with the personal appeal and authority of person-toperson communication. ${ }^{140}$ Playing the game then became the occasion for many families to imagine what it meant to be an American. ${ }^{141}$ Because the Checkered Game of Life, played in the private sphere of the parlor, rewarded the virtuous life with success, and the play action of the game placed the accumulation those virtues in the public sphere, the game shaped the national character by encouraging and reinforcing the idea of one code of virtue applied to all Americans. The virtues constructed for individuals in The Checkered Game of Life were the very same values developed for the nation. The Myriopticon, a miniature moving panorama created as a parlor game by Milton Bradley \& Co. in 1866, is analyzed in the next chapter, and reveals what happens when Southerners violated those national virtues. The Historiscope, a miniature moving panorama created in 1868 , is analyzed in the fourth chapter, and presents the origins of the national character.

140 Morgan, Protestants and Pictures, 25.

141 Anderson, Imagined Communities, 6. 


\section{CHAPTER 3: THE MYRIOPTICON, A HISTORICAL PANORAMA OF THE REBELLION}

\section{Introduction}

Milton Bradley \& Company, purveyors of family parlor games and portable games for soldiers, manufactured a miniature moving panorama titled The Myriopticon: A Historical Panorama of the Rebellion in $1866 .{ }^{142}$ (refer to figure 1.3) The Myriopticon consisted of a paper scroll of twenty-four chromolithographed scenes copied from illustrations on the pages of Harper's Weekly and housed within a decorated pasteboard box about five inches tall and eight inches wide. The product presumed an operator who turned a hand crank to advance each scene into position behind a proscenium cutout as a lecturer recited descriptions of the images and their significance. The scroll and the stage were accompanied by several accessories: a seven-page script, a sheet of admission tickets and an advertising poster. The Myriopticon performances took place in the family parlor; the Directions to the Proprietor of the Myriopticon that came with every game recommended the use of parlor draperies to "increase the effect" of the show.

\footnotetext{
${ }^{142}$ The Great Rebellion was a term used in the Union in 1866 to identify the war between free and slave states that had just been fought. Harper \& Brothers published a history of the war in two volumes in 1866 and 1868 under the title of Harper's Pictorial History of the Great Rebellion in the United States. The running heads of both volumes read "Harper's History of the Great Rebellion." At some point after 1868, Harper's \& Brothers changed the title to Harper's Pictorial History of the Civil War, but they left the running heads to read "Harper's History of the Great Rebellion."
} 
Thesis

Milton Bradley \& Company's Myriopticon recalled the Great Rebellion in wartime images and interpretations familiar to Union audiences. However, the Myriopticon did more than recount historical events with familiar scenes. It repurposed those scenes to curate a particular narrative that replaced the idea of sectionalism that characterized the nation in the years leading up to and during the Civil War with the idea of one nation resting firmly on the foundation of industrial capitalism. Its domestic performance replicated the gendered division of labor and values of middle-class respectability and deportment required for the maintenance of that economic system. For one, the narrative rendered women invisible; only two scenes include women, placed in the margins in supporting roles. Men, on the other hand, take active part in all the scenes. The Myriopticon worked alongside other middle-class media to define what the Union believed a unified American society should be and how its young performers and viewers could appropriately participate in it. It did so, moreover, in a direct, sequential fashion that established causality and indicated the preservation of the Union was ordained because of the rightness of the Union cause and their ability to fight a modern war with superior resources. Ultimately, the ideological message produced by the game focused on the triumph of industrial capitalism, and more specifically, the multiple specialized roles men could play in an inevitable march of progress. 


\section{Museum Theater}

Milton Bradley \& Company situated the Myriopticon within middle-class social expectations and standards of deportment represented by the "museum theater," the respectable, family oriented theater first created in the 1840 s and 1850s by P.T. Barnum in New York City and Moses Kimball in Boston to resemble the middle-class parlor, the epicenter of respectable domesticity and cosmopolitanism. ${ }^{143}$ The Directions to the Proprietor included instructions suggesting how to create a "museum theater" in the parlor with the proper theatrical atmosphere for the show: "If the pictures are exhibited in the evening, it may be an improvement to place a light behind the picture, having the rest of the room darkened. Curtains hung in a bay window or doorway, and drawn around the case of the Myriopticon with the operator concealed from view, increase the effect. In that case the person reading or repeating the lecture should be in front."144 Also included was an advertising poster that provided humorous guidance for proper behavior in this respectable theater: audience members were "to remain seated till the close of the first scene," while “Gentlemen with bricks in their hats will please deposit them at the Ticket Office for safe keeping." The proscenium cutout,

143 Bruce A. McConachie, Melodramatic Formations: American Theatre and Society, 1820-1870 (Iowa City: University of Iowa Press, 1992): 170; Katherine C. Grier, Culture and Comfort: Parlor Making and Middle-Class Identity, 1850-1930

(Washington and London: Smithsonian Institution Press, 1998), 10. Kimball bought the Boston Museum in 1838 and in 1843 added a theater, expanding it in 1846 to seat 2,500. P. T. Barnum bought the Scudder's American Museum in New York City in 1841 and added a theater in 1849, expanding it to hold 3,000 in 1850. The theaters were called "moral lecture rooms" at the time. Many more soon followed suit in New York City and Boston as well as Philadelphia, Baltimore, Albany, Providence, Troy, etc.

144 Bradley \& Co., "Directions to the Proprietor of the Myriopticon," one sheet. 
complete with chromolithographed drapery decoration, provides a proper frame for every scene. The Myriopticon's success was highlighted in a letter sent by a satisfied customer, B. R. Davis. ${ }^{145}$ Davis described how every evening his family (he, his wife, their five children and his brother) gathered in the parlor to look and listen to the Myriopticon performance. The family appointed him, as the authority figure of the typical American family of the period, as operator and narrator. They created a theater in their parlor by arranging the drapery and the lighting to focus attention on the proscenium and on him as the performer and invited the neighbors over to watch the performance too.

\section{$\underline{\text { Reconstruction }}$}

Placing the performance of a story about the Great Rebellion within the family parlor during Reconstruction connected the Myriopticon with an educational mission. Milton Bradley \& Company published the Myriopticon in a political climate that supported Republicans, who controlled the U.S. Congress and Senate, every Northern state legislature, and every governor's office. ${ }^{146}$ However, this support was not absolute; in 1864, for example, Lincoln won $91 \%$ of the electoral college but only $55 \%$ of the popular vote. This distinction led public figures to make public education a cornerstone of Congressional Reconstruction. ${ }^{147}$ Reconstruction was not about rebuilding, but rather, propagated the message that the industrial,

145 Shea, It's All in the Game, 81.

${ }^{146}$ John White, Reconstruction after the Civil War, 23.

147 Ibid, 30. 
capitalist American culture practiced in the North was the best way to "reconstruct" the loser of the war.

The Myriopticon fit well with the re-education efforts of Reconstruction. The twenty-four scenes did not romanticize the story of the Great Rebellion with one victorious battle after another. The Myriopticon, for example, featured several notable Union defeats including Bull Run, the 1862 Peninsula Campaign, and the disastrous battle of Fredericksburg. A majority of the images represent the equipment of war and the institutional organization necessary to prosecute a modern war. The Myriopticon curated a memory of the Great Rebellion that made visible the struggle involved and the resiliency required to put down the rebellion.

Popular media surrounding the Myriopticon

The Myriopticon's twenty-four moving scenes and script recorded what reasonably informed Union families already knew to be important subjects concerning the war. Americans witnessed the war primarily through illustrated news magazines, and Harper's Weekly, produced by Harper and Brothers publishing house in New York City, was the premier illustrated news magazine in the country during the war years. Given the pressure from the American public for current news during the war, large and successful news media concerns like Harper and Brothers could afford to hire and embed their own artists in the military services to report and illustrate the war. All but one of the images in the Myriopticon first appeared in Harper's Weekly. The images in the Myriopticon were familiar to middle class families not only because they viewed them in Harper's Weekly, but 
they were interpreted in Harper's Weekly editorials. The illustrations, news, and editorials became central to shaping public opinion. The North American Review, in their April 1865 issue, called Harper's Weekly "the most powerful of the organs of public opinion."148 Citing it's "vast circulation, deservedly secured and maintained by the excellence and variety of its illustrations of the scenes and events of the war," the literary journal concluded Harper's Weekly "has done its full part in the furtherance of the great cause of Union, of Freedom, and of Law."149

In addition to employing the powerful interaction of images and text, the Myriopticon relied on the prevailing wisdom of mid-nineteenth century historical writing through its chronological organization of the scenes. Emma Willard introduced her popular textbook, History of the United States, or Republic of America: with a Chronological Table and a Series of Progressive Maps (1864), by asserting that chronological order was the only way to ground "the mass of knowledge" in "objective" reality. ${ }^{150}$ Facts and dates were considered to be of utmost importance. Indeed, the Directions to the Proprietor inform the performer that the script's "historical statements and dates are intended to be absolutely accurate."151 Therefore, the battle scenes included in the Myriopticon are placed in chronological order, and the seven-page script includes dates and facts to orient the story of the Great Rebellion. The scene sequence deviates from chronological order only at the

\footnotetext{
148 __ "Harper's Weekly. Journal of Civilization. 1857-1864," review of Harper's Weekly, The North American Review 100, no. 207 (April 1865): 623. 149 __ "Harper's Weekly. Journal of Civilization. 1857-1864," 624. 150 Emma Willard, History of the United States, or Republic of America: with A Chronological Table (New York: A.S. Barnes and Burr, 1864), iii.

151 Bradley \& Co., "Directions to the Proprietor of the Myriopticon," one sheet.
} 
end of the story, which was purposefully altered for dramatic effect to stress that the demise of the Confederacy was ordained.

The Myriopticon also stressed the same subject matter as early histories of the war that appeared in the two or three years after it ended, written by authors sympathetic to the Union cause. More than one-third of the images and all the events described in the Myriopticon can be found in Harper's Pictorial History of the Great Rebellion, an illustrated narrative of the war published in two volumes by Harper and Brothers, the first volume in 1866 and the second volume in 1868. Well-known historian Benson J. Lossing stressed these same events in his Pictorial History of the Civil War in the United States of America, published in 1866. The attendant circumstances of war so prominent in the Myriopticon, such as the technology for communications, special forces and their specialized weapons, new naval ships and weaponry and newly developed institutions for the care of the wounded are also illuminated in Lossing's history of the Rebellion. In an 1866 review of "Lossing's Pictorial History of the Civil War" slated to be published shortly, Godey's Lady's Book and Magazine assured its readership that the two volumes would contain greater than " 2000 illustrations" and that "the eye is well instructed concerning the materials used in the conflict."152

The visual and text format of the Myriopticon was familiar to families from stereoscope cards that permeated the domestic setting of their parlors. Both Mathew Brady's and Alexander Gardner's studios produced photographs of the war that were displayed in galleries and widely distributed in popular stereograph card

$152 \ldots$ _Lossing's Pictorial History of the Civil War," Godey's Lady's Book and Magazine LXXII (May 1866): 466. 
sets. Because most Americans today visualize the Civil War through the lens of photography, they assume photography was the primary source for the scenes in the Myriopticon. However, only one of the scenes in the Myriopticon, "Contrabands Coming into Camp," appeared as a photograph, and even then, the Myriopticon image is copied from a Harper's Weekly sketch that appeared in the January 31, 1863 issue. $^{153}$ (refer to figure 3.10)

Whereas the visual and text format, parlor viewing, and some of the subject matter, especially the equipment of war, of the Myriopticon was similar to stereography, the style of the scenes employed in the Myriopticon dramatically differs. The scenes utilized in the Myriopticon are active, placing us in the "smoky sway of battle," as Harper's Weekly stated in an article entitled "Our Artists During the War."154 The Myriopticon scenes reconstructed the action and movement of the sketches made by artists in the many theaters of war. Included with every game, the Myriopticon advertising poster proclaimed "This Panorama is copied from the sketches of our most celebrated artists, taken from nature, on the spot, as soon after the events therein depicted transpired as was consistent with their personal safety." Because sketches could capture movement, the Myriopticon scenes described the many activities of war. Photographs of the era could only capture static subjects such as portraits, dead bodies and the equipment of war after fighting.

\footnotetext{
${ }^{153}$ A. R. Waud. "Contrabands coming into camp in consequence of the Proclamation," Harper's Weekly VII, no. 318 (January 31, 1863): 68. 154 _. "Our Artists During the War," Harper's Weekly IX, no. 440 (June 3, 1865): 339 .
} 
What also set the Myriopticon apart is that the illustrations do not only depict motion, but are also set in motion. In this way, Milton Bradley \& Company connected the Myriopticon to the full-scale moving panoramas that first became popular in the United States in the 1840s and 1850s. Milton Bradley \& Co.'s Work and Play Annual of Home Amusements and Social Sports from 1871-72, published an advertisement for the Myriopticon that sought to inspire parents' memories of the very popular Mississippi river panoramas of their childhoods. ${ }^{155}$ The Myriopticon, by association, became the perfect domestic version of fond childhood memories. The broadside included with the game was designed to recall one of the most famous, "Banvard's Mammoth Panorama of the Mississippi River." Like the Myriopticon, Banvard's panorama combined news and commentary to orient the viewer; a presenter editorialized the facts through a script to make the images comprehensible and meaningful for the viewer. Viewers were also familiar with the many full-scale moving panoramas about the battles of the Civil War, such as George W. Williams's Great Painting of the WAR! of 1861 produced in 1862 and Goodwin and Woodward's Polyrama of the War from 1863.

In imitation of full-scale moving panoramas, the Myriopticon's twenty-four scenes were placed one after the other in the scroll. This linear format, chronologically configured, gave rise to a narrative of time with a beginning, middle and end that established causality, making the Union's win inevitable because of their superior resources and ability to lead a modern war effort. ${ }^{156}$ As the political scientist and historian, Benedict Anderson wrote, history is created in "uptime"

155 Bradley \& Co., Work and Play, 36.

156Burnham and Giese, "Introduction," in Redefining American History Painting, 11. 
from the past to the present, and in retrospect with the understanding that a particular endpoint has already been determined. ${ }^{157}$

\section{Milton Bradley's History of the Great Rebellion}

Since Milton Bradley's Myriopticon is a miniature moving panorama, the scenes are set in motion. This helps strip the historical events of their complexity, allowing for the insertion of ideology through the creation of cause and effect in its narrative of time. ${ }^{158}$ The ideological messages the Myriopticon narrative sent affirmed a new identity for a reunited nation and positioned the viewer on the winning side of power. This construction legitimized the account as historical, not just current events, and formulated the national identity of the United States as industrial, modern and directed by white males of action. The story arc of the Myriopticon opened by showing how, in the beginning, the South aggressively started the war by rebelling against its own nation, and in the end, by doing so, brought total disaster on itself. The heart of the narrative made visible the struggle the Union went through to eventually win the war because of the rightness of their cause and because of what their economic system allowed them to do. The ideological messages included in the Myriopticon narrative made clear war was a masculine arena; there was no place for women except to watch and serve from the sidelines. The conduct of a modern war effort in the Western theater resulted in the

157 Anderson, Imagined Communities, 205.

158 Schivelbusch, The Railway Journey, 59; Oleksijczuk, The First Panoramas, 3; Jonathan Crary, Techniques of the Observer: On Vision and Modernity in the Nineteenth Century (Cambridge, MA and London: MIT Press, 1990), 104-105. 
successful defeat of the Rebellion. And by including two scenes concerning the effects of war on black people, the Myriopticon also made clear the important role they played in the war and grappled with defining a nation that included black men.

In the opening scenes one through four, the combination of text and image juxtaposes Revolutionary times with the time of the Rebellion to highlight the Confederacy's actions as treason. This is in no way a new interpretation; in fact, anyone reading news media of the time in the Union would have found this a dominant theme. In the first scene, the Myriopticon represented the heroism of Major Robert_Anderson and his men in the face of South Carolinian treason. (figure 3.1) The Myriopticon script reminded viewers the ancestors of those very South Carolinians fought valiantly during the Revolutionary War to form the United States of America, but now their treachery has made that nation vulnerable. Just how vulnerable was both shown in this scene and related in the script, as Major Anderson and his men were forced to steal away from Fort Moultrie to occupy the stronger federal fort, Fort Sumter, under cover of darkness on December 26, 1860. Viewers would have known Anderson was "the hero of the hour" since contemporary newspaper accounts referred to him that way, and gaged how successful the move was by reporting a rise in the stock market, a key economic indicator for the industrial capitalist system of the North..$^{159}$

The second scene established the Confederates as the aggressors in the Great Rebellion. (figure 3.2) The scene served as a visual echo of Lincoln's inaugural address on March 4, 1861, when he told the South: "In your hands, my dissatisfied

${ }^{159}$ Alfred H. Guernsey and Henry M. Alden, Harper's Pictorial History of the Great Rebellion in the United States (New York: Harper and Brothers, 1866), 29. 
fellow countrymen, and not in mine, is the momentous issue of civil war. The government will not assail you. You can have no conflict, without being yourselves the aggressors." ${ }^{160}$ The Myriopticon image presented the second day of the bombardment of Fort Sumter April 13, 1861, which the script reminded the viewer, not only ignited the fort but also the Civil War. Harper's Pictorial History of the Great Rebellion in the United States described Fort Sumter as the Rock of Gibraltar, a metaphor for the monumental strength of the United States government. ${ }^{161}$ The viewer was placed in the rebel batteries to clearly show the South was the aggressor, firing on their own nation. Placed on either side of the cannon being fired are two rebels with red shirts. Their placement directed the viewer's attention along the barrel of the big gun to the cannon ball beginning its trajectory. Streaks of red took the viewers' eyes to its target, Fort Sumter on fire! This image became iconic and appeared in many different forms of popular media, such as on period envelopes printed with the rallying cry "Remember Fort Sumter!"162

In the next two scenes, the Myriopticon set up the Union's vision of the essential differences between Union and Confederate citizens and foreshadowed the outcome of the story: disciplined, unified order wins over emotionalism, disobedience and rebellion. In scene three, the Union soldiers in blue uniforms on the left present a cohesive, disciplined, uniform group aiming their muskets on command and are referred to in the Myriopticon script as "the $6^{\text {th }}$ Massachusetts

\footnotetext{
160 Guernsey and Alden, Harper's Pictorial History of the Great Rebellion, 48 footnote 2. 161 Ibid, 61.

162 Library of Congress, Civil War envelope (1861), accessed March 17, 2019, https://www.loc.gov/item/2011648573/
} 
regiment" and as "Among the first that rallied to the defence [sic] of their country...."163 (figure 3.3) On the right, a crazy hodge-podge of legs, heads, arms and hands holding all kinds of weapons is described by the Myriopticon script as "a mob in the streets of Baltimore."164 Scene four underscored this distinction by memorializing the murder of Colonel Ellsworth at the hands of a man referred to in the script with only one name, Jackson. (figure 3.4) Today, Ellsworth is no longer remembered in the history of the Civil War, but readers of Harper's Weekly were kept up-to-date weekly on the exploits of this young, dashing officer and his Zouave regiment recruited from the ranks of the New York City Fire Department. ${ }^{165}$ The charismatic, self-reliant and industrious Fire Zouave Union commander was contrasted against Jackson, identified in the Myriopticon script only as "a hotelkeeper in Alexandria, Va.", but know to readers of Harper's Weekly as a notorious secessionist leader and "a man of violent habit ... and like too many Southerners, was prompt with knife and pistol."166

The Myriopticon established the rightness of the Union's cause by connecting the beginning scenes to the origin story of the nation and made the Union the legitimate heir to American revolutionary ideals. For example, the Myriopticon script for scene three editorializes: "This was the first blood shed in the great rebellion and it singularly occurred on the same day of the same month with the

\footnotetext{
163 Bradley \& Co. "Myriopticon Lecture," 2. ${ }^{164}$ Ibid.

165 Just a couple of the many articles and illustrations published in Harper's Weekly include: "Colonel Ellsworth of the Fire Zouaves," Harper's Weekly V, no. 228 (May 11, 1861): 289; "Willard's Hotel, Washington, Saved by the New York Fire Zouaves," Harper's Weekly V, no. 230 (May 25, 1861): 230. 166 __. "The Murder of Ellsworth," Harper's Weekly V, no. 233 (June 15, 1861): 369.
} 
first blood of the American Revolution shed at Lexington, Massachusetts, in 1775."167 In other words, the Sixth Massachusetts fought for freedom from the tyranny of "aggressive slavers" just as the American patriots, among them the ancestors of the Southerners in the Baltimore scene, fought for freedom from the tyranny of the British in the American Revolutionary War. The viewer of scene four would have understood that Colonel Ellsworth was the first officer killed in the war and would have connected that death to the founding of the nation, as news stories and editorials of the period pointed this out. The Lounger, a weekly column on Harper's Weekly's editorial page, dated June 8, 1861, connected Ellsworth's death to the death of General Joseph Warren 86 years previous, the first officer killed when British troops stormed the redoubt of Breed's Hill in the Battle of Bunker Hill. The editorial explained "As Warren died in the beginning of the struggle to obtain Constitutional liberty, so dies Ellsworth at the opening of the war to maintain and perpetuate it." ${ }^{168}$

After establishing the South's treachery and the North's allegiance to Revolutionary ideals, the Myriopticon's next seventeen scenes illustrated five reasons for the Union's eventual victory: industrial development; new communication technologies; medical advances on the battlefield; new labor resources; and a new model of leadership for a modern, industrial war. The scenes constructed traits for the individual to emulate, among them self discipline and virtuousness, that supported the industrial capitalist base for the reunified nation

167 Bradley \& Co., "Myriopticon Lecture,” 2. 168 354. . "The Lounger - Ellsworth," Harper's Weekly V, no.232 (June 8, 1861): 
and allowed any viewer to envision their participation. Satisfied customer Davis made this clear in his letter to Milton Bradley \& Company when he wrote about his brother. "In the part about the first Battle of Bull Run where he was at and fought, he always speaks up in a loud voice to say he was one of those who holt up at Centerville [sic] and not among the cowards who run on to Washington."169

First, the Myriopticon established the importance of an industrial base and the institutional organization needed to effectively implement it in order to design, manufacture and operate new war equipment. In scene sixteen, for example, a sharpshooter, concealed in a tree, fills the frame. (figures 3.5 and 3.6) The only image dedicated to a single figure, this focus allowed the Myriopticon narrative to highlight the importance of the rifle, the training needed to use it effectively, and serves to define the self-disciplined individual. Shown in a red shirt so the viewer can readily see him, in battle he would wear camouflage green or gray. He is a study in concentration as he aims a breech-loading rifle at an unidentified target. In the words of the Myriopticon script, he "fires whenever he sees the head of an enemy."170 But, any reader of Harper's Weekly would have understood how these special forces members were used as skirmishers at the front to pick-off enemy officers and gunners, and been well informed about the technical qualities of the sharpshooter's training and rifle. ${ }^{171}$ To accomplish this specialized job, concealment was of utmost importance, and therefore possessing a breech-loading rifle was

\footnotetext{
169 Shea, It's All in the Game, 82.

170 Bradley \& Co., "Myriopticon Lecture," 5.

171 "Colonel Berdan and His Sharpshooters," Harper's Weekly V, no. 243 (August 24, 1861): 540; "The Berdan Sharpshooters at Weehawen," Harper's Weekly V, no.249 (October 5, 1861): 625.
} 
imperative because it allowed the sharpshooter to load his gun from many different positions, even clinging to the branches up in a tree.

Another example of the importance of an industrial base, and how innovation in the North would change the world can be seen in scene ten, the encounter between the Monitor and the Merrimac. (figure 3.7) This event and the image we see in the Myriopticon became iconic, not for who won - both sides claimed victory - but for what it meant for the future of naval vessel design and battle strategies around the world. The Myriopticon script reminds the viewer that "all nations" were watching and taking notes. ${ }^{172}$ Visually, the scene makes clear the encounter has made wooden sailing warships obsolete, and it is the Monitor with her revolutionary innovations that will rewrite ship design and naval battle strategies.

Scene ten, depicting the Monitor and Merrimac engaged in battle made it clear to the world's navies that the age of the wooden ship had come to an end in naval warfare. Those wooden ships have been pushed to the background and are disappearing in the smoke of gunpowder from the big guns of the ironclads and the steam from their engines. Harper's Pictorial History of the Great Rebellion observed that: "When the tidings of this fight crossed the Atlantic, the London Times affirmed that England had on the day before 149 first class war-ships; now there were only two; beyond these there was not one that could without madness, be pitted against the Monitor."173

In scene ten, it is the Monitor that would have engaged the viewer's immediate attention for she is placed in the most forward position in the image, and

172 Bradley \& Co., "The Myriopticon Lecture," 4.

173 Guernsey and Alden, Harper's Pictorial History of the Great Rebellion, 256. 
at an angle, creating a sense of forward motion. The Myriopticon script introduces the scene by stating how familiar the audience will be with the ships and the event: "The scene now coming into view will be readily recognized as the encounter between the Merrimac and Monitor ...." The viewer could readily see that the Monitor looked radically different than any other naval vessel they would have seen before, and were kept well informed about the design and technical aspects of this new vessel by the press, for example in Harper's Weekly. ${ }^{174}$ The Monitor was not a chimera of old and new naval vessels like the Merrimac built on the salvaged hull, boilers and engine of the USS Merrimack with the addition of "inclined iron-plated sides and submerged ends." 175 Instead the Monitor was a revolutionary new design, built entirely of metal. Her draft was shallow, ideally suited to the shoaling waters of rivers that the war required naval vessels to operate in. The Merrimac, being built on a wooden warship hull, had a very deep draft that significantly hampered her ability to maneuver. And the Monitor incorporated a radically new innovation, a revolving turret, in her design. The turret allowed the guns to be aimed at any point in a circle without having to move the vessel, as well as mount guns that could fire heavier shot. The guns the Monitor carried were described by Harper's Weekly as "2 - 11 inch Columbiads, which have been furnished with 400 wrought-iron shot, each ball costing $\$ 47$, and weighing 184 pounds, made on purpose for smashing in the

174 "The Naval Combat in the Chesapeake," Harper's Weekly VI, no. 273 (March 22, 1862): 177 and 183 - included an illustration of the Monitor, a blow-by-blow description of the battle, and many technical details of both ships; "Captain Erisson," Harper's Weekly VI, no. 274 (March 29, 1862): 203 and 204 - the article furnished several plans for the Monitor.

175 Edward A. Pollard, Southern History of the War: The First Year of the War (New York: B. Richardson, 1865), 268. 
sides of such rebel floating batteries as the Merrimac, where cast-iron shot would break to pieces."176 The bow was further adapted to make the Monitor a powerful steam-ram. Harper's Pictorial History of the Great Rebellion considered that the guns were "a heavier ordnance than had ever before been placed in any vessel. ${ }^{177}$ Even the Confederates were impressed. Edward A. Pollack, author of Southern History of the War considered at the time to be" the only history of the war published by a citizen of the Confederacy," described the Monitor as "the celebrated iron battery, a wonderful-looking structure that was justly compared to a prodigious "cheese-box on a plank,' said 'cheese-box' being of a Plutonian blackness."178

The Myriopticon's second theme used a narrative image of action to introduce the importance of communications to waging modern warfare. In the foreground of scene fourteen, running men in blue uniforms unravel a wire on a reel. (figure 3.8) They are members of the United States Telegraph Corps and the Myriopticon script informs the audience they are "erecting telegraph wires on the battlefield under fire."179 A smoky battlefield with massed armies provides the background. In the middle ground, a two wheeled horse-drawn cart that houses transmitting and receiving equipment waits as the two men string telegraph wire

\footnotetext{
176 Harper's Weekly, "The Naval Combat in the Chesapeake," 183.

177 Guernsey and Alden, Harper's Pictorial History of the Great Rebellion, 253 Columbiads, because of their size and weight, were usually used as a seacoast defensive weapon mounted on land, not an offensive weapon mounted on a vessel. On the water, battle strategy is to sink enemy vessels; therefore the heavier the shot, the more effectively it can destroy a ship. The Monitor's turret allowed for bigger guns with heavier shot and less maneuvering required for more accurate aim. ${ }^{178}$ Edward A. Pollard, "Publisher's Announcement," in Southern History of the War: The Last Year of the War (New York: Charles B. Richardson, 1866); Pollard, The First Year of the War, 272.

179 Bradley \& Co., "The Myriopticon Lecture," 5.
} 
from pole to pole in the foreground. The Myriopticon script informs the audience "In an engagement a telegraph wire is frequently followed up as fast as ground is gained, and thereby a commander at his headquarters is constantly informed of operations in the several parts of the field." ${ }^{180}$ By illustrating a scene of action during battle, viewers of the Myriopticon saw that the Union's ability to wage modern warfare by creating a network of communication with the telegraph led to its successful war effort.

Third, the Myriopticon represented the results of developing a system of timely care of the wounded soldier. The script oriented the viewer of scene fifteen by announcing that they were looking at the "celebrated" stone bridge made famous in "a terrible fight by the forces under Burnside" to ensure the audience understood the scene involved the battle of Antietam. ${ }^{181}$ (figure 3.9) The public was made aware of the human costs of saving the Union at Antietam, the bloodiest single day of the war, in static images of dead soldiers by Mathew Brady, Alexander Gardner and other photographers published widely on stereoscope cards used in the parlor setting. ${ }^{182}$ But in the Myriopticon, the viewer instead saw a scene of organized action, which the script informs the viewer "represents the wounded being cared for." Instead of a celebration of the first Union victory in the Eastern theater, the image shows surgeons, wounded soldiers, ambulances, and stretcher-bearers. The color red effectively drew the viewer's attention to splotches of blood on a draped table and on a soldier transported via a stretcher. The viewer saw the efficient

180 Bradley \& Co., “The Myriopticon Lecture," 5.

181 Ibid.

182 Emily Godbey, “'Terrible Fascination:' Civil War Stereographs of the Dead," History of Photography 36, no. 3 (July 9, 2012): 268. 
coordination of care from operating table to stretcher transport to waiting ambulance to the arrival of another ambulance on Burnside's bridge. Families were kept well informed by Harper's Weekly of the efforts of the U.S. Sanitary Commission charged with development and oversight of best practices for the care of Union soldiers. ${ }^{183}$

The Myriopticon introduced the development of an important labor resource, emancipated slaves and free men of color, as a necessary part of a successful Union war effort. In scene eighteen, the script identifies a mutigenerational black family group as "contrabands coming into camp, and having just arrived are now sitting for their pictures."184 (figure 3.10) Captured by Harper's Weekly artist Alfred_R. Waud in a sketch (David B. Woodbury photographed them in a slightly different configuration), they are posed in front of their dilapidated mule cart, a carpet thrown over it for a cover instead of canvas. ${ }^{185}$ (figure 3.10) The black men were neutralized in this scene by their domestic situation, poverty, and static poses. Harper's Weekly kept readers informed week after week about the efforts extended by the government to employ run-away and then emancipated slaves. Scene eighteen is placed chronologically according to the date the Emancipation Proclamation took effect, January 1, 1863. The audience of the Myriopticon performance was exposed to many editorials and news articles on the topic of what

\footnotetext{
183 Just a sampling of issues includes: "The Health of the Volunteer," Harper's Weekly V, no. 236 (July 6, 1861): 418; almost the entire issue of Harper's Weekly VIII, no. 382 (April 23, 1864): 257-272.; "Mississippi Valley Sanitary Fair," Harper's Weekly VIII, no. 385 (May 14, 1864): 306. ${ }^{184}$ Bradley \& Co., "The Myriopticon Lecture," 6.

185 Library of Congress, "Arrival of Negro family in the lines," accessed March 17, 2019, https://www.loc.gov/photos/?q=LC-B811-657
} 
to do about four million slaves held in the South. One Harper's Weekly editorial published just a month after the war began, entitled "To Our Southern Readers," stated: "Actual war between Slave and Free States ultimately involves abolition."186 Another article, dated January 10, 1863, stated "our recent reverses supply additional motives for securing the active aide of 4,000,000 slaves, if it can be done.... Necessity will compel us to use them as soldiers." 187

In scene twenty-three, a regiment of black soldiers marches in formation led by their commanding officer, the charred ruins of buildings forming a backdrop. (figure 3.12) The Myriopticon script informs the audience they are looking at "the colored troops of the United States enter[ing Charleston, S.C..] where originated the whole plot of the rebellion."188 The Myriopticon performance, therefore, brought this conflict full circle, from the firing on Fort Sumter that began the war in Charleston Harbor to the fall of Charleston at the close of the war, signifying the end of the slave system and the opening of a new labor resource. The Myriopticon scene pictures former slaves cheering on the triumphal march of the United States $55^{\text {th }}$ Colored Regiment. Viewers of the Myriopticon performance would have been reminded of the Harper's Weekly illustration "Marching On!" and the commentary provided in which this event was pronounced a revolution in relations between "the

\footnotetext{
186 322. “To Our Southern Readers," Harper's Weekly V, no. 230 (May 25, 1861): 187 “Negro Emancipation," Harper's Weekly VII, no. 315 (January 10, 1863):

18.

188 Bradley \& Co., "Myriopticon Lecture," 7.
} 
negro and his master." 189 Black people now had a new master - the industrial capitalist economic system.

Lastly, the Myriopticon introduced a new model of leadership for a modern industrial war. Scene nine presented the reason for the first Union victory that occurred at the battle of Fort Donelson by introducing the leader who eventually brought the war to a conclusion that saved the nation, Ulysses S. Grant. (figure 3.13) The scene focuses on three boats in the middle of a river belching black smoke with Fort Donelson in the background marked by a flying flag. The boats represented formidable weapons of the United States Navy. The script informs the audience that the successful surrender of this fort also took serious fighting by the United States Army under the command of General Grant. Therefore, the visual and the script work together to inform the viewer that the successful outcome of the battle sprang from Grant's leadership in the use of war strategies and modern weapons made possible by the industrial capitalist age.

The Myriopticon emphasized the role of the Western Theater in Union victory. The Myriopticon performance includes six scenes of battle victories in this theater and therefore showed what everyone in the Union knew: that the Western Theater involved an almost unbroken string of battle victories for the Union. The Myriopticon made the turning point in the Great Rebellion the Union victory at the battle of Vicksburg, secured through the modern leadership of General Ulysses S. Grant. In scene nineteen Grant literally rides in on a white horse to save the nation. Victory at Vicksburg, July 4, 1863, solidified Grant's reputation as a fighting general “Marching on!” Harper's Weekly IX, no. 429 (March 18, 1865): 165, 172. 
who commanded from the field not from behind a desk. (figure 3.14) Pictured with his sword drawn, leading the Union to victory, a direct connection was made to General George Washington, the leader of the American Revolution and the Father of the nation, always also shown as a leader who commanded from the field of battle. For example, Washington is pictured in Milton Bradley \& Co.'s Historiscope, a panorama of American history, on horseback with his sword drawn. ${ }^{190}$ Victory at Vicksburg opened up the route to Atlanta. In scene twenty, Union soldiers literally and figuratively washed up after taking the heart of the Confederacy in September of 1864. (figure 3.15)

The apocalyptic end

The last three scenes in the Myriopticon described the apocalyptic end of the rebellion. Positioned as a metaphor for that end, scene twenty-two describes the sinking of the C.S.S. Alabama. (figures 3.16 and 3.17) This is the only event that is out of chronological order, having occurred in June of 1864, and contrary to all other events narrated in the script, this event is not given a date, even though the Directions to the Proprietor of the Myriopticon impress upon the presenter their importance. Placed in the center of the scene, a large ship lists at the stern, its masts and rigging in disarray. Viewers had been kept so well informed by news media sources of the Alabama's treasonous exploits against Union commerce on the high seas over the two previous years that the script needed only to inform the viewer

\footnotetext{
190 Milton Bradley \& Co., "Portrait of George Washington appointed Commander-inChief of the American Army," The Historiscope A Panorama and History of America (Springfield, Mass.: Milton Bradley \& Co., 1868), scene eighteen.
} 
they are witnessing "the sinking of the Alabama by Kearsarge off Cherbourg, France" for the viewer to understand that the United States had dealt a critical blow to the Confederacy. ${ }^{191}$ Harper's Weekly ended their story announcing Alabama's

destruction by quoting from a poem about shipwreck and the fates by John Milton:

“'Built I' the eclipse and rigged with the curses dark' she has gone down to her own place. May the Rebellion of which she was a fitting instrument, soon follow her!"192 This sinking ship of the Confederacy, therefore, became a metaphor for the fated inevitability of Union victory. Scene twenty-three illuminated the end of the Confederacy's slave system against the backdrop of the ruins of Charleston. (refer to figure 3.12) And the final scene shows the retreat of the defeated Confederate army silhouetted against towering flames, as Richmond, the head of the Confederacy, was utterly destroyed. (figure 3.18)

This final scene of apocalypse brought the story arc to a conclusion that deliberately spelled out the defeat of the Confederacy. Although every other scene in the moving panorama show was copied from the pages of Harper's Weekly, this scene of the Burning of Richmond was not. Whereas Harper's published an illustration of the Union Army marching in triumph into Richmond, the Myriopticon presented Richmond burning to the ground. The story arc required that, according to fate, the Confederacy "go down to her own place" in flames.

191 Bradley \& Co., "Myriopticon Lecture," 6. Just a sampling of articles and illustrations include: “The Pirate 'Alabama,' Alias '290,' Certified to be Correct by Captain Hagar of the 'Brilliant,'” Harper's Weekly VI, no. 305 (November 1, 1862): 689; “The British Pirates 'Oreto' and 'Alabama,'” Harper's Weekly VI, no. 313 (December 27, 1862): 818; “The Approach of the British Pirate 'Alabama,'” Harper's Weekly VII, no. 330 (April 25, 1863): 268.

192 __ "The 'Alabama,'” Harper's Weekly VIII, no. 394 (July 16, 1864): 450. 
At the very beginning of the Rebellion, Harper's Weekly wrote in an editorial titled "A Political Catechism for Children," that this ending was ordained. The last lines of this editorial read "But if you have read your Bible right, and have the true instincts of a free-born American Boy in you, you can not doubt how the contest will end."193 The Myriopticon narrative showed why this end was inevitable.

\section{Conclusion}

Satisfied customer of the Myriopticon, B.R. Davis, ended his letter to Milton Bradley \& Company by writing: "I thank you for making it and hope many buy so as to make it less crowded in our parlor these evenings." ${ }^{194}$ Assigned as purchasers by Victorian gender codes, women reinforced the message of the Myriopticon in the parlor by purchasing Currier and Ives prints of the war, stereoscope card sets, Harper's Weekly news magazines, history books of the Civil War, and sheet music with songs of the Civil War for the parlor piano to surround the guests and family. Even though women were relegated in the Myriopticon narrative to watching and supporting, their role as educator of the virtuous citizen ensured any boy eight to twelve, the target market for the Myriopticon, would understand the message and the role he could play in the industrial capitalist economic system that won the war.

What message would a young boy see and hear in the narrative of the war portrayed in the Myriopticon? First he saw the divine rightness of the cause of Union. From the second scene, where he was placed behind the canons being fired

193 "A Political Catechism for Children," Harper's Weekly V, no. 245

(September 7, 1861): 562.

194 Shea, It's All in the Game, 82. 
by the rebels, he saw Confederates in rebellion firing illegally on his nation, and therefore he knew the war must be fought. He understood who the hero of the Union cause was and why, because Grant understood how industries moved people and products. He learned only men waged war and played an active part as citizens of the nation. He learned the importance of and respect for organizing the war effort by institutions. He understood that men needed to specialize and become experts, necessary attributes in the new post-war world he would be coming of age in. The Myriopticon visualized ample examples of this specialization: special-forces like sharpshooters, trained ambulance drivers and stretcher bearers, telegraph and signal corpsmen, engineers, inventors, artillerymen, surgeons. The Myriopticon allowed any boy to dream of what he wanted to be when he grew up. It is not surprising, therefore, that the letter sent to Milton Bradley \& Company was written by a father and made the nuclear family the center for instruction in the traits to emulate in this newly unified industrial capitalist nation. 


\title{
CHAPTER 4: THE HISTORISCOPE, A PANORAMA AND HISTORY OF AMERICA
}

\author{
Introduction
}

Milton Bradley \& Co. first published The Historiscope, A Panorama and History of America in $1868 .{ }^{195}$ (refer to figure 1.4) The fledgling game company designed this miniature moving panorama with the same dimensions as the Myriopticon, $51 / 2$ inches tall, $81 / 4$ inches wide and $2 \frac{1}{4}$ inches deep, and with the same operational design: a proscenium cut out through which twenty-five scenes were viewed by an audience. The Directions to the Proprietor of the Historiscope, similar to those included with the Myriopticon, recommended two performers for its operation, an orator who recited from an eight-page lecture in front of the audience and an operator who worked the moving panorama behind the scenes. The family parlor was designated as the scene of the performance, enhanced as a theater with strategically placed curtains and the suggestion that piano music be added. ${ }^{196}$

Unlike the Myriopticon, instead of creating the theater of the Great Rebellion, the Historiscope creates the theater of American history. The 1871-72 issue of Work and Play Annual of Home Amusements and Social Sport described the

\footnotetext{
195 Emily L. Schulz, "The Historiscope: A Nineteenth-Century American History Toy,” Cincinnati Fourteen: Journal of the Society of the Cincinnati 43, no.2 (2007): 71. 196 Milton Bradley \& Co., "Directions to the Proprietor of the Historiscope," a paragraph on the last page (page 8) of the "Historiscope Lecture."
} 
Historiscope as "a panorama of America from the discovery by Columbus to the close of the revolution" and pronounced that performing the show would allow a child to learn "more of the early history of America than he will learn of the same subject in school in a year."197 Whereas the Myriopticon performance placed capitalism at its center, performing the Historiscope over and over again within the setting of the parlor theater became the occasion for the realization of "an imagined political community - and imagined as both inherently limited and sovereign."198

The placement of the Historiscope performance within the domestic space of the family parlor reveals a shift in the role of the family from producer to instructor brought about by the evolving capitalist economic system. ${ }^{199}$ In the gendered world that capitalism enforced in order to control relationships of power, men led from outside the family and women supported American values from within the family. In their supporting role, women became the nurturers and purchasers. Since women were placed in charge of raising the virtuous citizens of the nation, citizens who conformed to their prescribed roles, the purchase and performance of the Historiscope could be used as a tool to help achieve this goal. The Historiscope instructed the viewer in how to be a "good citizen" of a virtuous nation, and the events that make up this narrative were portrayed as part of a holy-design carried

\footnotetext{
197 Milton Bradley \& Co., Work and Play Annual, 36.

198 Anderson, Imagined Communities, 6, 145.

199 Margaret K. Hofer, The Games We Played: The Golden Age of Board and Table Games, New York Historical Society's Liman Collection [exh. cat.] (New York: Princeton Architectural Press, 2003), 13.
} 
out by founding fathers who exhibited all the moral characteristics necessary to create that virtuous nation. ${ }^{200}$

The Historiscope decoration, and the scenes of history within, construct this gender dynamic. (refer to figure 4.1) The chromolithographed decoration of the Historiscope box connected this moving panorama not only to a narrative of national origins and identity with inflections of capitalism, but also to Victorian gender codes that enabled the gender bias of this story. Pairs of female theatergoers sit in box seats on the margins of the "stage," positioned to both watch the show and be watched. They enable the telling of the story. Below each is a putto. Holding a shield with the stars and stripes, the putto on the left represents the United States of America. Holding a palette and brushes, the putto on the right represents the arts in service to building the story of that nation; he has painted the proscenium a patriotic red, white and blue, and provided splashes of color for the scenes of history that scroll by behind the proscenium cut-out. Men, on the other hand, were placed in all the scenes of the Historiscope. White males of European ancestry were given active roles in creating and administering that nation and therefore figure prominently in the story told in the Historiscope itself. Women appear in only three of the twenty-five scenes and only in the margins, in supporting roles.

200 Cremin, American Education, 73. 
Thesis

In this chapter, I treat the Historiscope as a tool used to help heal the schism in national identity that had led to the Great Rebellion. All nations need a narrative of identity. ${ }^{201}$ The Historiscope presented that narrative of identity for the United States in an origin story. This origin story educated its audiences in how the nation came to be and what it meant to be an American, and celebrated the idea of a reunited American nation. The message of national identity carried in the images and the text that accompanied the Historiscope were familiar to Americans in many forms of print media they would have seen and read in their everyday lives, both before and after the Civil War.

This origin story shaped national identity as an industrial capitalist nation, justified existing hierarchies of wealth and power, and illuminated behaviors considered appropriate for the citizens of that nation: industriousness, perseverance, loyalty, belief in self-government, religious freedom, and egalitarianism - at least among white men of Northern European ancestry. Setting the twenty-five scenes chosen in the Historiscope in motion, the recognition of those images and their outside sources in the minds of the viewers, and the orientation provided by the eight-page script that comes with the miniature moving panorama worked together to reinforce this identity for the American nation. The story started with the discovery of a vast new continent with an abundance of resources ripe for the picking by exceptional men of action who worked to bring a community together to create the conditions necessary to exploit those resources, thereby facilitating

201 Anderson, Imagined Communities, 204. 
industrial capitalism. The Historiscope performance showed that in this process, men transported civilization from the Old World to the New World, men built English Protestant settlements that triumphed over wilderness to create regional founding stories and to form exceptional political principles of self-government. ${ }^{202}$

The story arc of the presentation concluded that when men brought these various regions together because of common interests, they were able to overthrew the tyranny of the mother country to form a sovereign state free of economic oppression.

Story of national identity facilitated by print media

The Historiscope presented the origin story of the United States with the same events included in the earliest history books by Noah Webster from 1806 and 1807.203 This same origin story was also told in a large static panorama format

202 Truettner, William H. The West as America: Reinterpreting Images of the Frontier, 1820-1920 [exh. cat.] (Washington and London: Smithsonian Institution Press, 1991), 41.

${ }^{203}$ A list of four books, from 1796(1811?), through 1809 follows: Webster, Noah. An American Selection of Lessons in Reading and Speaking. Calculated to Improve the Minds and Refine the Taste of Youth. To Which are Prefixed Rules of Elocution, and Directions for Expressing the Principal Passions of the Mind. Being The Third Part of a Grammatical Institute of the English Language, $10^{\text {th }}$ edition. Hartford: Hudson and Goodwin, 1796 (1811?); Webster, Noah. An American Selection of Lessons in Reading and Speaking. Calculated to Improve the Minds and Refine the Taste of Youth. To Which are Prefixed Rules of Elocution, and Directions for Expressing the Principal Passions of the Mind. Being The Third Part of a Grammatical Institute of the English Language, $14^{\text {th }}$ edition. Hartford: Hudson and Goodwin, 1800; Webster, Noah. Elements of Useful Knowledge. Containing a Historical and Geographical Account of the United States; For the Use of Schools, third edition. Volume I. New London: Printed for O.D. Cooke, by Ebenezer P. Cady, 1807; Webster, Noah. Elements of Useful Knowledge. Containing a Historical and Geographical Account of the United States; For the Use of Schools, third edition. Volume II. Hartford: Hudson \& Goodwin, 1809. 
mounted in the Capitol rotunda, with eight oil paintings surrounding the viewer.

Four scenes of the American Revolution were installed from 1826 through 1828: Declaration of Independence, Surrender of General Burgoyne, Surrender of Lord Cornwallis, and General George Washington Resigning His Commission. ${ }^{204}$ The next four paintings, installed in the rotunda from 1840 to 1855, Landing of Columbus, Discovery of the Mississippi by De Soto, Baptism of Pocahontas, and Embarkation of the Pilgrims, tell the story of the discovery and settlement of North America through regional origin stories for New England, the South, and the West in the nation. ${ }^{205}$ The national origin story told in the Capitol rotunda and the Historiscope was the same origin story told through the nineteenth century in other public venues across the nation such as schools, published textbooks by a variety of authors, grade school readers, popular prints, postage stamps, bank notes, fine art and decoration of public buildings. Neither the violent events of the Civil War, nor the complaints from the landed elite of the slave states of the South in the 1850s and beyond, changed the origin story first created in the early 1800s.

The Historiscope scenes were organized into the same themes developed in early histories. The first theme was discovery of America. The second was building

\footnotetext{
${ }^{204}$ Architect of the Capitol. "Historic Rotunda Paintings," aoc.gov/artwork/type/historic-rotunda-paintings 205 Architect of the Capitol. "Historic Rotunda Paintings," aoc.gov/artwork/type/historic-rotunda-paintings The Historiscope miniature moving panorama includes six of the eight events included in the Capitol rotunda panorama (the two scenes from the Capitol rotunda not presented in the Historiscope are Surrender of General Burgoyne and General George Washington Resigning His Commission). Of the six scenes that the Historiscope has in common with the rotunda paintings, two copy the paintings (Landing of Columbus and Discovery of the Mississippi by De Soto) and the other four, while not copies, involve the same historical subject.
} 
settlements and colonies with exceptional principles of self-government. The third was Indian Wars that helped define common interests, providing a pivot point for the plot. The fourth theme was escalating hostilities between the American colonists and the mother country, Britain, which resulted in what was perceived as a "profound rupture with the existing world."206 The fifth theme was the war for sovereignty.

The images Milton Bradley \& Co. copied in the Historiscope miniature moving panorama were images the audience would have readily recognized since they came from many popular media sources. The most prominent sources for the scenes in the Historiscope are history textbooks; twenty of the twenty-five scenes appeared in textbooks prior to being included in the Historiscope. In a memoir published in 1953, entitled The Schoolhouse at Prairie View, Marshall A. Barber (1868-1953), renowned bacteriologist at the University of Kansas, describes an image he remembers more than seventy-five years in the past from an American history textbook he studied in that prairie schoolhouse.

Our [history] book was fair enough; there was little or no attempt at propaganda in it. It was full of pictures, chiefly of people notable in the history of the United States or of the colonies. I remember well a woodcut of a palisade used by the colonist during King Philip's War. A bold Indian, maybe King Philip himself, was shown wandering around outside the enclosure, reminding one of a boy seeking a knothole during a baseball game. ${ }^{207}$

206 Anderson, Imagined Communities, 193.

207 Marshall A. Barber, The Schoolhouse at Prairie View, (Lawrence: University of Kansas Press, 1953), 34. 
The history textbook he is referring to is probably Charles A. Goodrich's History of the United States of America published in 1867.208 The image is also in Benson J. Lossing's Pictorial History of the United States for Schools and Families published in 1858, in A Primary History of the United States. For Schools and Families published in 1867, and in A Centennial Edition of the History of the United States: From the Discovery of America to the End of the First One Hundred Years of American Independence published in 1876.209 The image he describes is scene eleven in the Historiscope. Since this image, like many other images in the Historiscope, appeared in many issues of textbooks and the textbooks circulated in schools across the nation, it becomes clear how recognizable these images became. In this anecdote, a viewer even recalled the image's historical context seventy-five years later!

Other popular media forms that Historiscope scenes appear in were fine art paintings, popular prints, postage stamps, bank note engravings and stereoscope cards. Although Congress extended copyright statute to protect art design in 1806, none of the scene illustrations in the Historiscope are credited to any artists. ${ }^{210}$ In

\footnotetext{
${ }^{208}$ Charles A. Goodrich, History of the United States of America; for Use of Schools; revised and brought down to the present time by William $H$. Seavey, principal of the Girl's High and Normal School (Boston: Brewer and Tileston, 1867), 43.

${ }^{209}$ Benson J. Lossing, A Primary History of the United States. For Schools and Families New York: Mason Brothers, Boston: Mason and Hamlin, Philadelphia: J.B. Lippincott and Co., Cincinnati: Sargent, Wilson and Henkle, Chicago: George and C.W. Sherwood, 1867), 67; Benson J. Lossing, Pictorial History of the United States for Schools and Families (New York: Mason Brothers, San Francisco: H.H. Bancroft, and Co., 1858), 101; and Benson J. Lossing, A Centennial Edition of the History of the United States: From the Discovery of America to the End of the First One Hundred Years of American Independence Hartford: Thomas Belknap, 1876), 127 footnote 1. ${ }^{210}$ Kevin Liftig, "The Evolution of Copyright Law in the Arts," University of Connecticut, Honors Scholar Thesis, 2009.
} 
fact, none of the history textbooks provide credits for the illustrators either.

Printers working in the mid-nineteenth century made copies of history paintings, for example the paintings in the Capitol rotunda, as well as contemporary prints, and virtually never distinguished between these two sources. ${ }^{211}$ They also often transformed the images in small, all the way to large, ways as they reproduced these images. ${ }^{212}$ Images in the mid-1800s circulated freely.

\section{.Connection to Liberal Protestantism}

The didactic messages of the Historiscope fit well with the educational mission of Reconstruction. ${ }^{213}$ As part of the educational mission of Reconstruction, the Historiscope acted as an agent of the liberal Protestant movement that believed reform could move American society toward perfection. The instructive and performative natures of the Historiscope fit well with two of the tenants of this Protestant movement: the movement located moral agency in the individual and it encouraged active participation. ${ }^{214}$ The scenes were constructed to abound with men of action who moved events forward in a constant march of progress toward the ultimate ordained goal of sovereignty as a united nation. ${ }^{215}$ Milton Bradley \& Company reinforced the original message of the origin story told in the first histories, of the righteousness of a unified nation, by using that same origin story after the Civil War in the Historiscope. Just as is presented in the Myriopticon, the

${ }^{211}$ Finlay, "Introduction: Taking a Fresh Look at Nineteenth-Century Lithography," in Picturing Victorian America, 3.

212 Ibid, 6.

${ }^{213}$ The official dates of Reconstruction are 1865 to 1877.

${ }^{214}$ Cremin, American Education, 212.

215 Morgan, Protestants and Pictures, 30. 
emergence of a sovereign United States of America out of the ashes of war was presented in the Historiscope as ordained by God. The American nation was believed to have a special role to play in developing a higher level of civilization, and the origin story demonstrated what that looked like.

The Historiscope reinforced the virtuous characteristics taught in Protestantism, and constructed them as necessary in order to create a unified, orderly, and righteous nation, at a time just after the conclusion of the war fought over the Great Rebellion of the South. ${ }^{216}$ Rebellion, presented in the Myriopticon as the antithesis of order, union and righteousness, was perceived by the Northern states as a selfish action by the Southern states, in which the South did not act for the greater good, and the result of such self-interest was disaster. The men who were presented building the nation in the origin story told in the Historiscope all acted for the greater good of the nation. Performing an origin story that presented a nation filled with men modeling the behaviors citizens should have and achieving a sovereign nation that was orderly, unified and righteous as a result, was an important part of reinforcing the idea of a once again united nation working toward a higher level of civilization.

The work that the Historiscope did was to instruct the audience in how to be that "good citizen." It is in the household where this nurturing occurred, where the mother protected the family from the "ubiquitous evil" of selfishness lurking outside the walls of the home. According to scholars, preachers and Milton Bradley \& Company, countering the "traps of Satan multiplying even at our very doors" took

216 Cremin, American Education, 73. 
surrounding the family with innocent and instructive recreations that came from many sources external to the domestic sphere. ${ }^{217}$ The company stated, there is "no class of influences more potent" to protect the family "than the introduction of social games" such as the Historiscope..$^{218}$

In products such as the Historiscope and the Myriopticon, Milton Bradley \& Company enlisted visual images, facilitated by emerging technologies of the industrial capitalist economy such as chromolithography, to promote middle-class identity and aid in the task of shaping personal character. By the second half of the nineteenth century, Americans were increasingly exposed to visual imagery in the culture all around them: in advertising, illustrated magazines like Harper's Weekly, books, newspapers, popular prints, parlor games, stereoscope card sets, and much more, and because of this citizens accepted the power of images to influence thought and behavior and shape character both individually and nationally. ${ }^{219}$ In the January 18, 1849 issue of the Hartford Daily Courant, "Notes by a Man About Town" connected chromolithography with elevating public morals and refining national character through education in the home:

Prints are now produced from drawings on stone, which possess nearly all the beauty and delicacy of steel and copperplate engravings, and at a price which brings them within the easy reach of all classes. Scarcely a cottage or hamlet can be found however obscure or isolated, but what display upon its walls ... specimens of this art, pleasing the eye, enlivening the solitude, informing the mind, and cultivating ... that taste for the fine arts which everywhere tends to

217 Milton Bradley \& Co., Work and Play Annual, 3.

218 Ibid.

219 Morgan, Protestants and Pictures, 323. 
refine and ennoble humanity." ("Notes by a Man About Town,"

Hartford Daily Courant, Jan 18, 1849, Vol. 13, p. 2) 220

This is just the kind of observation that would appeal to nineteenth-century middleclass American citizens. They tended to be non-proselytizing, liberal Protestants who believed civility, manners and taste were marks of refinement and bestowed membership in the middle-class. ${ }^{221}$

The use of the technology of chromolithography in the Historiscope to mass produce fine art paintings for many of the scenes that scroll by behind the proscenium demonstrated a shift from the moral tone of The Checkered Game of Life with its programmatic image style to the inspirational tone exhibited in the Historiscope with its "artistic" images. ${ }^{222}$ At least half of the chromolithographed images in the Historiscope can be traced to fine art painting sources. ${ }^{223}$ Aesthetic education became part of the mission of parlor games in order to influence the formation of character. ${ }^{224}$ Liberal Protestants embraced the idea of American progress toward a higher civilization by supporting the achievement of this goal of perfection through social progress. The Historiscope fit well with the goal of reform by enlisting the help of twenty-five artistic images the audience members would

${ }^{220}$ Finlay, "Introduction: Taking a Fresh Look at Nineteenth-Century Lithography," in Picturing Victorian America, 1.

${ }^{221}$ Morgan, Protestant and Pictures, 272.

222 Ibid, 268.

${ }^{223}$ Scene 2: Landing of Columbus; Scene 3: Discovery of the Mississippi by De Soto; Scene 6: Pocahontas Saving Captain John Smith; Scene 7: Landing of the Pilgrims; Scene 8: New Amsterdam; Scene 9: William Penn's Treaty with the Indians (1683); Scene 15: First Blow for Liberty; Scene 16: The Death of General Warren at the Battle of Bunker Hill; Scene 18: Taking the Salute at Trenton; Scene 22: George Washington at Valley Forge; Scene 23: Major Israel Putnam at Horseneck, Connecticut; Scene 24: The Capture of Major André; Scene 25: Surrender of Cornwallis.

${ }^{224}$ Morgan, Protestants and Pictures, 268. 
readily recognize from many different sources: the national capitol images disseminated in print form and on paper money, history textbooks, popular prints they used to decorate parlors, textbooks they studied in school, stereoscope cards they viewed in their parlors, etc. The ever-expanding world of print media provided the means for re-presenting the united American community in the post-Civil War years. ${ }^{225}$ These images, organized in the Historiscope linearly and then set in motion, carried messages to reacquaint family members and guests with what a united nation stood for and how its citizens should support it.

\section{A Southern origin story not published}

Why would a parlor game produced by Milton Bradley \& Co. that told the national origin story especially resonate with prospective customers just after the Civil War? In the 1850s, a decade of rapidly escalating sectionalism between slave and non-slave states, that story fell under attack by proponents of slavery in the South. With the addition of territories that doubled the landmass of the United States at the end of the Mexican-American War in 1848, the states whose economies depended on slavery insisted on expanding slavery into these territories. With resistance from the states operating on the foundations of an industrial capitalist economic system, a sectional schism grew rapidly. One of the manifestations of the sectional schism was rejection by the Southern elite of the American origin story. The Southern elite complained they wanted a different origin story told, one that rested firmly on the foundations of the Southern slavery system. They particularly

${ }^{225}$ Anderson, Imagined Communities, 25. 
criticized the origin story for depicting Southern settlers and colonists as lazy and uneducated in comparison to settlers and colonists in New England, and they felt the South was underrepresented in text space. Also, because the South was very sensitive about any portrayal of slavery, all histories of America were judged as always containing attacks on the institution of slavery. ${ }^{226}$

However, prior to the 1850s, the origin story told in the Historiscope was the story every Southern student studied, since no one in the South expressed concern about the Northern monopoly on all aspects of education. The textbooks students used in the South were all written and published in Northern cities, since there were no publishing houses with national distribution systems in any of the slave states. A majority of the teachers working in Southern schools came from the North (75\%), and were trained in Northern teachers colleges since there were no colleges to train teachers in the slave states. 227 The Southern elite did not value education for anyone other than their own children. ${ }^{228}$ An example of the result of poor funding for education by Southern legislatures is that, by 1835, more than two-thirds of the children of wealthy Mississippi planters attended schools in the North. ${ }^{229}$

The Historiscope origin story presented a picture of a fundamentally different government from the government envisioned in an origin story the South

\footnotetext{
${ }^{226}$ Barry Joyce, The First U.S. History Textbooks: Constructing and Disseminating the American Tale in the Nineteenth Century (Lanham, Boulder, New York, London: Lexington Books, 2015), 233. The Southerner did not use the word "slavery." Slavery was referred to in the South as "our peculiar institution." ${ }^{227}$ Joyce, The First U.S. History Textbooks, 227. Therefore, it was in the North that all the innovative theories, practice and training in education occurred.

${ }^{228}$ Not all Northerners supported education for all however, especially wealthy merchants.

${ }^{229}$ Joyce, The First U.S. History Textbooks, 225.
} 
wanted told. Whereas the Historiscope origin story visualized a government that educated all its citizens to control the machinery of their government, government by the people for the people, the Southern elite insisted on an origin story founded on a social system of chivalry and a political system where the government controlled the people. They supported a government that would educate only the white elite citizen to direct the slave labor of the state in order to champion the Southern system of slavery as having secured the economic prosperity of the nation. ${ }^{230}$

Even after the war, the origin story told in the Historiscope continued to experience resistance from Southern elites. Some Southerners demanded the American origin story showcase Southern noble culture as the driving force for creating a higher culture in America. That origin story would have presented the nobleman as the representative American. The nobleman embodied his own authority; he was what he represented, and he came from the old system of monarchical hierarchy. ${ }^{231}$ The writings of Edward A. Pollard, a Virginian journalist and author supported this system of government of planter elites who control a slave system of labor to serve the elites' economic interests. Writing just after the war, he published the four-volume Southern History of the War in New York City starting in 1866, voicing continued resistance to the concept of the representative American presented in the origin story told in the Historiscope:

${ }^{230}$ Joyce, The First U.S. History Textbooks, 239. 231 Jürgen Habermas, The Structural Transformation of the Public Sphere: An Inquiry into a Category of Bourgeois Society, translated by Thomas Burger with the assistance of Frederick Lawrence (Cambridge, Massachusetts: The MIT Press, 1989), 8. 
Free labor founded in the North a material civilization, a pestilent system of public schools, and that insolent democracy which went by the phrase, "D_n you, I am as good as you." That, and "commercial" politics, made the North prosperous; a showy, glittering mass of all the national elements of civilization, by the side of the apparently scanty, but refined, South.... Yet after all, the Yankee trader had a sneaking, irrepressible consciousness that the Southern planter...was infinitely his superior as a gentleman; that he could not compete with him in courage, in the sentiment of honor, in the refinements of manners, or in any of the solid and meritorious accomplishments of manhood..... Slavery introduced elements of order and conservatism in the society of the South; and yet, after all, there was no truer democracy in the world than there.... Slavery trained the white race of the South in habits of command; ... they were generally the occasions of the revival of the spirit of chivalry in the nineteenth century; of the growth of many noble and generous virtues; and of a knightly polish of manners, that the shopkeeping aristocracy of the North, being unable to emulate, was satisfied to ape in its hotels and caravansaries. ${ }^{232}$

The representative American in the origin story told in the Historiscope was instead a free self-actualizing personality who was what he produced, a new idea brought on by capitalism in the North. ${ }^{233}$ Given that the South did not have publishing houses with the capacity to produce and distribute textbooks even within the Southern states, no textbooks with a rewritten origin story that showcased Southern noble culture was ever produced.

The Historiscope re-inscribed the "Northern" interpretation of the origin story, insisting that the "Northern" version become the American version. The "Northern" version reinforces the attributes of industrial capitalism supported by self-actualizing citizens who are educated in order to control their government. However, in practice, the result was the same as what some in the South fought for: government by white elite men for white elite men.

232 Edward A. Pollard, Southern History of the War: The Last Year of the War (New York: Charles B. Richardson, 1866), 271-272.

${ }^{233}$ Habermas, The Structural Transformation of the Public Sphere, 13. 


\section{The Origin Story}

The Historiscope origin story performance was conceived to build consensus, not just among families in the north but to unify the disparate regions of the nation to transcend differences and create a single identity, a proper interpretation of what it meant to be an American and how America came to be. In self-consciously choosing the events that tell the origin story, the Historiscope didn't just preserve the past but it also shaped the nation's identity by transmitting morals and lessons to the next generation. Milton Bradley \& Company did this by self-consciously choosing "forgotten" events on behalf of dead white men whose sacrifices made possible the nation. ${ }^{234}$ These events occurred far enough in the past so they could be shaped to construct, unchallenged, an identity for the nation. ${ }^{235}$

The Historiscope origin narrative provided a past that began in 1492; it imagined fellowship among white males of European ancestry, and dreamed of a sovereign future. ${ }^{236}$ The scenes chosen to create this story were arranged in a sequence of events that described a story arc of exploration and discovery, settlements and colonization, and a quest for sovereignty. ${ }^{237}$ The Historiscope used the same elements Benedict Anderson, the preeminent political scientist and historian, has identified as the elements all national myths share: the story was told

\footnotetext{
${ }^{234}$ Anderson, Imagined Communities, 201.

235 Ibid, 204.

236 Ibid, 154.

237 Joyce, The First U.S. History Textbooks, 5. These themes are the same themes found in all myths, traditional stories concerning the early histories of peoples: emergence and migration; stories that explain origins i.e. defining characteristics of a culture; struggle for and formation of "The People;" and providence and destiny.
} 
in "uptime" from past to present and because of this a "start" date had to be determined, the community was described as a fraternity, and its citizens were willing to sacrifice and die for the idea of nation..$^{238}$

\section{Exploration and Discovery}

Four "discovery" scenes (Group of Native Americans, Landing of Columbus, Discovery of the Mississippi by De Soto, and Henry Hudson Discovering New York) created a sense of an immemorial past for the nation. ${ }^{239}$ These scenes in the Historiscope show Europeans landing in the New World and discovering a wilderness sparsely populated by savages. Seeking a water route to the East, or gold in the New World, or a passageway to India, these early explorers from the Old World "discovered" three important regions of the United States: the West, the East and the South. Cast by the Historiscope as modern men of action, they set into motion chains of events that ultimately created a nation called the United States of America. ${ }^{240}$

\footnotetext{
${ }^{238}$ Anderson, Imagined Communities, 143-144, 205.

239 Ibid, 11-12.

${ }^{240}$ Samuel G. Goodrich, The American Child's Pictorial History of the United States. Illustrated by sixty engravings (Philadelphia: E.H. Butler and Co., 1868), 24-25. Samuel G. Goodrich states in The American Child's Pictorial History of the United States that the discovery Columbus made "was one of the greatest events in the history of the world!" He explained that leading the way to the great continent of America across the Atlantic Ocean set in motion all of the "great" change that has taken place since: "Where the city of New York stands - now containing almost a million people, with houses, railroads, ships, steamboats, manufactories, churches, school-houses - the land was occupied by Indians; the woods were infested by bears and wolves; otters and beavers dwelt upon the borders of the streams, and seals sported in the waters along the sea-shore....Millions of acres are now teeming with rich products, such as hay, wheat, corn, rye, oats, barley, potatoes, and other things, which were then only the abode of wild and savage beasts, or more savage men."
} 
Scene one in the Historiscope pictures a "group of Native Americans" and described them visually as little more than animals to underscore the idea that although a group of them pre-existed in this New World, civilization did not. ${ }^{241}$ (figure 4.1) Five warriors, arranged haphazardly, fill the space with their wild hair, animal skin robes, and little red shoes, the composition punctuated with the vertical shafts of their spears. The composition gave the viewer no hint as to who was the leader of these men, a view in keeping with the history textbooks of the time. For example, Benson Lossing states in his popular text A Common School History of the United States: from the Earliest Period to the Present Time, "When men from Europe first came over the Atlantic and landed on the shores of America at different places, they found inhabitants of a copper color, who could give little account of themselves, as a people."242 The audiences' eyes were drawn to the center warrior dressed in imitation of a bear, juxtaposed with two warriors wearing bull's horn headdresses. The Historiscope script further colluded with the stereotype of Native Americans as savages perpetuated in the nineteenth century by connecting this scene to the volatile nature of the stock exchange, "as we evidently have in the foreground a 'Bear,' probably one of the Wall Street kind. The 'Bulls' are supposed to be in the background."243

Both the placement of this scene of indigenous "savages," the visual and textual language used to describe them, and the scarcity of images in the Historiscope involving indigenous peoples (there are only four included amongst

241 Bradley \& Co. "Historiscope Lecture," 1.

${ }^{242}$ Benson J. Lossing, A Common School History of the United States; from the earliest period to the present time (New York: Sheldon and Company, 1870), 5.

243 Bradley \& Co., "Historiscope Lecture," 1. 
twenty-four scenes) was in keeping with American history textbooks of the time. The Historiscope image can be found in the 1858 history textbook Pictorial History of the United States for Schools and Families by Benson J. Lossing. ${ }^{244}$ Like the Historiscope, most United States history books contained a chapter early in the book to establish the insignificance of the people Europeans encountered in the New World. The historian Benson Lossing established difference and the uncivilized state of the native population when he wrote in 1867 that although the English encountered "the copper-colored people who lived in this country hundreds of years ago, ...the Indian would not cut down the trees and raise grain, except here and there a little patch." ${ }^{245}$ The historian Richard Hildreth dismissed the native population when he wrote in The History of the United States of America, Volume 1, in 1877: “...we have no reason to suppose that the total Indian population within the territory of the United States east of the Rocky Mountains, at any time subsequent to the discovery of America, exceeded, if indeed it even reached, three hundred thousand individuals. Such was the state of the aboriginal population when North America first became known to Europeans."246

At the juncture of scene one and two a warrior turns to the right, toward the future, since this is the direction in which the moving panorama moves forward. (figure 4.2) He gestures to a teepee, the symbol for "Indian" in nineteenth-century visual culture. The opening of the teepee frames native plants from the new continent, perhaps maize and tobacco - important agricultural products from this

\footnotetext{
${ }^{244}$ Lossing, Pictorial History of the United States, 7.

245 Lossing, A Primary History of the United States, 10.

${ }^{246}$ Richard Hildreth, The History of the United States of America, Volume 1 (New York: Harper and Brothers, Publishers, 1877), 66.
} 
New World, symbolizing a land ripe for the picking by the Old. Native American plant decorative motifs play a prominent role in the U.S. Capitol decoration, for example the incorporation of tobacco plants in the capitals of the columns that make up the Hall of Columns in the House wing, and the corncob capitals in a first floor vestibule.

With the Landing of Columbus in scene two, the Historiscope made clear that the American origin story began with the establishment of civilization brought from the Old World, a sophisticated world, to the New World, a wilderness. (figure 4.3) The Historiscope script states "We will therefore proceed to our first scene of historical interest, which presents Christopher Columbus landing on a little island belonging to the group since called Bahamas, one of the West Indies."247 Audiences were well schooled in the idea that the "discovery" and "civilizing" of the New World made visual in this second scene of the Historiscope was ordained. They learned this in any American history textbook they read; for example, Benson Lossing wrote in his text, A Common-School History of the United States from the Earliest Period to the Present Time: "God did not design this continent to remain a wilderness. In his own good time he permitted the white man to find it. The white man came with the industry and arts of civilization, and changed the appearance of all things. Where the Indians hunted and fished, are seen farms, villages and cities; ...." 248

Scene two established a full accounting of who the men were as a people and their legitimate claim to this land and its resources by composing those men in

247 Bradley \& Co., "Historiscope Lecture," 1. ${ }^{248}$ Lossing. A Common School History of the United States, 9. 
hierarchical order with Columbus at the lead. ${ }^{249}$ The scene established difference between the people in the previous scene found living in the New World wearing animal skins, and the people who had just arrived from the Old World wearing tailored courtly clothes. Those courtly people were depicted carrying royal banners and a processional cross proclaiming their legitimacy because they were Christians and were connected to the royal houses of the Old World. This view of legitimacy was reinforced by the fact that no indigenous peoples were included in scene two. The Daily National Intelligencer, a Washington D.C. newspaper published daily from 1813 to 1867, supported this view when it proclaimed in 1846: "No subject can be more interesting to the American than the landing of Columbus, the discovery of a world, and that world emphatically ours."250

The audience was familiar with the image of Columbus's landing included in the Historiscope scroll as well as the accounting of that event in the script. Milton Bradley \& Company copied the composition of this scene from John Vanderlyn's painting Landing of Columbus (1846), which Congress installed in the United States Capitol Rotunda in 1847. The United States Post Office reproduced this scene on a postage stamp in 1869, part of a series of special historical events and one of the first bicolor stamps issued in the United States. The Historiscope script directly quoted the popular historian Washington Irving's biography A History of the Life and Voyages of Christopher Columbus (with no attribution of the source) first published

${ }^{249}$ Anderson, Imagined Communities, 204-205.

250 Daily National Intelligencer, October 3, 1846, from Ann Uhry Abrams, "National Paintings and American Character: Historical Murals in the Capitol's Rotunda," in Picturing History: American Painting 1770-1930 [exh. cat.], ed. William Ayres (New York: Rizzoli, 1993), 75. 
in 1828 , when it recounted the struggles Columbus encountered to secure financial backing for his expedition: “... having waited in anxious expectation several years at the Court of Ferdinand and Isabella, of Spain, he was about leaving in despair. At this moment, Queen Isabella, animated by a noble enthusiasm, uttered those words which secured to her country the glory of the great discovery. She exclaimed: 'I undertake the enterprise of my Crown of Castile, and will pledge my jewels to raise the necessary funds!"251 Versions of this story were repeated in many school textbooks.

By portraying Columbus as a man of science yet a man of humble beginnings, the Historiscope established the nation as founded on the principals of science by men who were not aristocrats but instead were curious, adventurous, and desired to win wealth and recognition in a land of unlimited opportunity ripe for exploitation. ${ }^{252}$ In scene two, Columbus steps into the light on the shore, representing a new kind of man of genius, energy and resolve who God used to reveal a new world for a new people like him. The script informed viewers that Columbus came from humble beginnings, since "his father was a wool-comber, which occupation his ancestors had followed in the same city for many generations." ${ }^{253}$ However, the script made clear that Columbus broke that mold because he was exceptional: “But Christopher's passion was for the study of geography and navigation: and at the age of fourteen he entered upon a seafaring

251 Bradley \& Co., "Historiscope Lecture," 1. Washington Irving, The Life and Voyages of Christopher Columbus, first published in 1828 (New York: Thomas Y. Cromwell and Co., ?), 75.

${ }^{252}$ Samuel Eliot Morison, Admiral of the Ocean Sea: A Life of Christopher Columbus (Boston: Northeastern University Press, 1983), 6.

253 Bradley \& Co. "Historiscope Lecture," 1. 
life."254 The script portrayed Columbus as an enlightened thinker, and portrayed the intellectual climate in Europe as one in which many superstitiously believed the world was flat. ${ }^{255}$ The script states: “He made voyages, studied charts, conversed with veteran mariners, and became convinced that the world was round, and that by sailing westward land would be discovered."256 Since the United States was conceived as a community, a deeply connected fraternity, it is not surprising that Columbus, a white male, becomes the first of many "founding fathers" in the Historiscope narrative..$^{257}$

Scene three, The Discovery of the Mississippi by De Soto in 1541, connected the origin narrative not only to North America but more specifically to the western part of the United States, and also, because of De Soto's death shortly after "discovering" the Mississippi, provided an early exit from the origin story for the Catholics. (figure 4.4) The Historiscope script states: "De Soto landed on the western coast of Florida, and in the Spring of [1541], after two years fruitless search for gold, he came upon the Mississippi, near the southern limit of the present State of Tennessee."258 However, in contrast to the previous discovery scene with Columbus, canons and artillerymen together with two men struggling to plant a large Christian cross, were placed prominently in the foreground, hinting at the

254 Bradley \& Co. "Historiscope Lecture," 1.

${ }^{255}$ However, in reality, most of Europe in the $15^{\text {th }}$ century believed the earth was round. What scholars did not know was the circumference of Earth. The Historiscope script subscribed to "the myth of the Flat Earth." Historians such as Jeffrey Burton Russell have written that this myth flourished between 1870 and 1920 and was a product of struggles over evolution.

256 Bradley \& Co. "Historiscope Lecture," 1.

${ }^{257}$ Anderson, Imagined Communities, 7, 143.

${ }^{258}$ Bradley \& Co., "Historiscope Lecture," 2. The script incorrectly notes the date as "1751" but I think this is simply a typographical error. 
cruelty and treachery in the name of religion promoted by the Old World colonizers, the Catholics. Audiences were well versed in negative accounts of Catholic exploration. For example, Daniel Webster, senator and well-known nineteenthcentury orator, addressed this topic in his speech commemorating the completion of the Bunker Hill monument on June 17, 1843: "Spain descended on the new world in the armed and terrible image of her monarchy and her soldiery.... Spain translated power.... Everything was force. Territories were acquired by fire and sword."259 The Historiscope script continues: "The next year [De Soto] died upon [the Mississippi's] banks, and was buried in its waters. His followers built boats and floated down the river to the Gulf of Mexico."260 In effect, the Catholics died, and those that did not, left America.

Scene three worked well for the origin narrative because the event occurred long enough ago for the meaning to be controlled as the regional origin story for the West. Audiences would have been familiar with the image chosen by Milton Bradley \& Company as it is copied from the painting in the capitol rotunda finished by William H. Powell in 1853 and placed in the rotunda in 1855. Powell had a color lithograph made of it, an engraving of the image appeared on the reverse of the ten dollar bank note in the 1860s and the painting was reproduced in many American history textbooks, such as Samuel Goodrich's The American Child's Pictorial History

259 Daniel Webster, An Address Delivered at the Laying of the Cornerstone of the Bunker Hill Monument, fourth edition (Boston: Cummings, Hilliard, and Co., 1825), 24. The Bunker Hill monument is pictured in scene seventeen of the Historiscope. 260 Bradley \& Co., "Historiscope Lecture," 2. 
of the United States (1868). ${ }^{261}$ U.S. Congressmen selected The Discovery of the Mississippi by De Soto in 1541 to represent the West region in the U.S. Capitol rotunda, rejecting the first suggestion to picture Daniel Boone's settlement west of the Mississippi because that event had happened too recently to avoid generating controversy. ${ }^{262}$ Scene three depicted De Soto opening the untamed west for European settlement, important to the idea of a nation in mid-nineteenth-century America especially because victory in the Mexican American War (1846-1848) had resulted in the ceding of much Mexican territory in the far west of the continent to the United States, extending the American nation from the Atlantic to the Pacific.

With the arrival of Henry Hudson in scene four, the Protestants enter the story, "discovering" the important "Bay of New York." (figure 4.5) The script entry for The Discovery of the Hudson River made clear that both England and Holland "discovered" the river, both Protestant countries: "In 1609, Henry Hudson, an English navigator, was sent out by a Company of Dutch merchants to seek a northwest passage to India." 263 The script connected this "discovery" to the future important port of New York with the words: "While exploring the eastern coast of America for this object, in September, 1609, he passed through the 'Narrows' and entered what is now called the Bay of New York."264 Continuing in words that established the land as a wilderness, the script states: "On the banks of this beautiful

\footnotetext{
261 Architect of the Capitol, "Historic Rotunda Paintings," aoc.gov/art/historicrotunda-paintings/discovery-mississippi-by-de-soto 262 Ann Abrams, "National Paintings and American Character: Historical Murals in the Capitol's Rotunda," in Picturing History: American Painting 1770-1930 [exh. cat.], ed. William Ayres, 77.

263 Bradley \& Co., “Historiscope Lecture," 2. 264 Ibid.
} 
river, Hudson found only an unbroken forest; but on his return to Europe he described the land he had discovered as the most beautiful in the world." 265 However, the image showcased the "little ship 'Half Moon"' front and center in the Hudson River, symbolizing the commercial power of seventeenth-centuryNetherlands, and served as a forecast for the future commercial domination of New York.

\section{Settlement and Colonization}

In the Historiscope narrative, discovery gave way to settlement and colonization of the New World from Jamestown in the south in scene five through the founding of Providence in the north in scene ten. The script for each of the scenes identified the men who populated them as Englishmen. History books of the times, such as Samuel Goodrich's The Tales of Peter Parley About America, corroborated this when they stated: "You will recollect that this country was settled by English people, and belonged to England. The settlements were called English colonies."266 "Here is a picture of an English gentleman and lady; they came from England: there are many English people in New York, and in other parts of America. They look very much like Americans."267 Peter Parley goes on to describe "some Spanish people," "some Turks," and "some Chinese" in New York, but does not add "They look very much like Americans."

\footnotetext{
265 Bradley \& Co., "Historiscope Lecture," 2. 266 Samuel G. Goodrich, The Tales of Peter Parley About America. With Engravings, revised edition (Philadelphia: Thomas, Cowperthwait and Co., 1845), 80. 267 Ibid, 35-37.
} 
The Historiscope scenes and script identify these Englishmen as great men, "founding fathers," who journeyed to the New World at various times, from various backgrounds, and for various reasons. The selection and interpretation of these journeys in the Historiscope origin narrative developed connections between these journeys in order to imagine nation, a special kind of community existing all in the same period in time. Connections between the "discovery" of New York harbor in scene four, the Settlement of Jamestown in scene five, the Landing of the Pilgrims in scene seven, and the founding of New York City, Philadelphia and Providence in scenes eight, nine and ten developed two themes. One theme was the creation of founding stories for the various politically important regions of America through the exploits of great men. The second theme provided an evolution of the nation's exceptional political principles and commerce, anticipating the day of economic and political independence when the government for the people and by the people would spring forth fully formed.

Scene five, the Settlement of Jamestown, Virginia, presents the founding story for the South and the character of the men who settled the Southern colonies. Although the scene illustrates men working to build the first permanent settlement in America, a palisaded stockade of log cabins in the wilderness, the Historiscope script tells the audience their work ethic was weak. (figure 4.6) The script states this "first settlement in America" was inhabited by "noblemen, gentlemen, and merchants...poorly fitted to grapple with life in the wilderness, being mostly unused to labor and despising it."268 History books of the time corroborated this portrayal,

268 Bradley \& Co., "Historiscope Lecture," 2. 
proclaiming the settlers of the Southern colonies as coming from a particular class of English society "in which restraints were not very rigid" and connected these characteristics to the warm climate of the South that led to indolence and ease, and therefore slave labor became attractive. ${ }^{269}$

In scene six, another "founding father," John Smith, makes his appearance to rescue the faltering first settlement. (figure 4.7) The Historiscope script informed viewers, "sickness spread among the colonists, their leader proved false, ..." and the incompetent settlers of Jamestown had to be rescued by “... a remarkable man of their number, named John Smith."270 The origin story identified him as "remarkable" in the script because he had no hereditary rank or wealth and he was a Protestant, not a Catholic. Defined by his leadership abilities, his bravery, his entrepreneurial spirit, and his fearless exploration, the Historiscope script delved into his biography in considerable detail. ${ }^{271}$

The story of John Smith was, however, but a prelude to introducing Pocahontas, who provided Southern elite families with the link to royalty and the land, that they used to legitimate their sense of noble culture. The Historiscope script recites that on one of his fearless explorations of the country, Smith was captured by the Indians and "brought before Powhatan, their King, and he was

269 Benson J. Lossing, A Common School History of the United States from the Earliest Period to the Present Time, 93. This theory, termed "cultural nationalism," is ascribed to J.G. Herder (1744-1803), a German philosopher, theologian, poet and literary critic; in F.M. Barnard. "National Culture and Political Legitimacy: Herder and Rousseau." Journal of the History of Ideas 44, no. 2 (Apr. - June, 1983), 231-253. 270 Bradley \& Co., "Historiscope Lecture," 3.

${ }^{271}$ Ibid. 
condemned to death."272 Pocahantas was described in the Historiscope script the same way she was described in countless history books: young, beautiful, pious, and the daughter of the king, and therefore a princess. "His head was laid upon a stone - the club was raised to strike the fatal blow, when, to the astonishment of all, Pocahontas, a young and beautiful daughter of Powhatan, threw herself upon the captain, and implored her father to spare his life. The maiden's prayer was granted, and the old savage sent Smith home with a guard of twelve men."273

The portrayal of Pocahontas in the origin story constructed the Victorian feminine ideal: pure, innocent, altruistic. Although she was portrayed as exceptional in this story, her actions were not independent; they served the purposes of men. This story appeared in textbooks from the earliest written by Noah Webster in 1796 up to and past histories written in the 1870 s, and each account repeated the story almost verbatim. ${ }^{274}$ The Historiscope account was no exception, although the script does admit "all this story of Pocahontas has of late been denied by some matter-offact historians, but we consider it too romantic and interesting to be so easily given up."275

Why at this particular time, the time of the Civil War, would some historians be trying to debunk this story? Whereas John Smith's actions saved the Jamestown settlement, Pocahontas's actions saved the "Southern tribes." Her royal lineage and piousness appealed to Southern sensibilities. Many of the elite families of Virginia

272 Bradley \& Co., "Historiscope Lecture," 3.

273 Ibid.

${ }^{274}$ Noah Webster, An American Selection of Lessons in Reading and Speaking 1796 (1811?), 95.

275 Bradley \& Co., "Historiscope Lecture," 3. 
traced their ancestry back to the son from Pocahontas's marriage with Virginia tobacco planter John Rolfe. With her conversion to Christianity and marriage to the respected Virginian John Rolfe and the bearing of a son, she became a cultural broker between ancient rulers of the New World and the most respectable families in Virginia. The Virginia aristocracy could therefore claim tribal lineage through royalty that gave them a connection to the New World by inheritance. ${ }^{276}$ In the years just before the outbreak of the Civil War, northern historians attempted to cast doubt on the historical accuracy of this scene, in an attempt to discredit the South's efforts to make the Pocahontas story a founding story in a history of their own. 277

The Landing of the Pilgrims on Plymouth Rock, 1620, scene seven, provided the founding story for New England and developed the northern characteristics. (figure 4.8) In the scene, men struggle against crashing waves to hold a boat against a massive rock that a group of men, women and children have stepped out on. Dressed in many layers of warm clothing whipped by the wind, they stand together surrounded by a wilderness. One young maiden stands forward from the others on the rock, the viewer's eye drawn to her since her cape, blowing out around her, is colored red. The script states: "tradition says it was the foot of Mary Chilton, a young maiden of the band, that first pressed 'Forefathers Rock....' ${ }^{278}$

The landing of Protestants in New England in scene seven also helped develop the second theme of the settlement and colonization part of the origin

276 Joyce, The First U.S. History Textbooks, 150.

277 Robert S. Tilton, Pocahontas: The Evolution of an American Narrative (Cambridge: Cambridge University Press, 1994), 148.

278 Bradley \& Co., "Historiscope Lecture," 3. 
story: the evolution of exceptional political principles of self-government and "religious freedom" necessary for government to spring forth fully formed when the nation became a sovereign state. The Pilgrims, in seeking a new home for their families in the New World, were portrayed as playing a critical role in the development of civil and religious governance. Scene seven positioned the maiden Mary Chilton forward and center to make clear that the Pilgrims brought their families, and had purer motives than the settlers in the Southern colonies because they sought relief from religious persecution at the hands of Catholics encountered in the Old World. The script states: "The Pilgrim Fathers were Englishmen, belonging to the sect of Christians called Puritans, who, through the persecutions of the Roman Catholics, had fled to Holland. There they remained twelve years and then resolved to go to America ...."279 The image and the text construct a northern tribe who planned to stay and make a home in New England, contrary to the southern tribe, portrayed by the Jamestown settlers who were men seeking personal fortune and were not adept at hard work or governance. The script made it clear that the Puritan's settlement succeeded "upon the barren coast of Massachusetts" and became a colony, when it stated the rock the maiden Mary Chilton first stepped upon is "still named and honored by their descendants" as "Forefathers Rock." 280 Daniel Webster (1782-1852), spelled out the reason for the success of the northern colony in his address to commemorate the $200^{\text {th }}$ anniversary of the landing in 1820, when he stated the Pilgrims had "already established their country. There were political institutions, and civil liberty, and

279 Bradley \& Co., "Historiscope Lecture," 3. ${ }^{280}$ Ibid. 
religious worship, ...established by consent, founded on choice and preference, how nearly do these fill up our whole idea of country!"281

The founding of New York City in scene eight developed the foundations of trade and commerce for the origin story. (figure 4.9) Henry Hudson's "discovery" in scene four opened up Manhattan Island, bought, according to the script, in a shrewd business deal with the Indians for only $\$ 24$ worth of beads and trinkets. ${ }^{282}$ In the foreground of scene eight, merchant ships clog the harbor and a derrick for loading and unloading cargo rises in the center, warehouses lining the shore, forecasting further commercial developments. The viewer sees a windmill rising above a harbor scene, marking the place as New Amsterdam, ensuring the viewer understood New York's destiny was to become the commercial center of the nation because its roots lay in the commercial greatness of the Dutch in the seventeenth century.

This is the one founding story in the Historiscope that is not present in the U.S. Capitol Rotunda. The opening of the Erie Canal in 1825 eventually made New York harbor the busiest harbor in the nation. It also was the port of call for most immigrants, a cheap labor force necessary to keep industrialization economically feasible. However, in the 1840s when Congress chose scenes to decorate the U.S. Capitol rotunda, New York City didn't have the political power to represent itself with a founding story. As the Historiscope script humorously points out, the city

\footnotetext{
${ }^{281}$ Daniel Webster, "Discourse, Delivered at Plymouth, December 22, 1820. In Commemoration of the First Settlement of New England." $2^{\text {nd }}$ Edition. Boston: Wells and Lilly, 1821.

https://babel.haithitrust.org/cgi/pt?id=mov.010506634830;view=1up;seq=5 282 Bradley \& Co., "Historiscope Lecture," 4.
} 
"has since increased somewhat in population and value."283 By the time of the manufacture of the Historiscope (in 1868), New York City eclipsed both Philadelphia and Boston politically and economically.

The Historiscope provided the next installment in the development of exceptional American political foundations by an exceptional man of action, William Penn in scene nine. (figure 4.10) According to the script, William Penn "visited the spot where Philadelphia now stands, and there made his famous treaty with the Indians" under the branches of an elm made visible in this scene spreading across the top of the image. ${ }^{284}$ It is an image many nineteenth-century Americans would have found familiar. Although it loosely copies Benjamin West's oil on canvas painting William Penn's Treaty with the Indians done in 1772, an engraving by John Hall was published by John Boydell as early as June 1775 and consequently many American history books included copies of this image (not credited to the artist and/or engraver).

The image shows Penn and his associates holding a large document representing Penn's treaty of pacifism and a unique colony constitution for the inspection of a group of Indians toward whom he gestures in negotiation. The Historiscope script states that Penn "determined to there [in Pennsylvania] try the 'Holy experiment,' as he calls it, of founding a free and happy home for the

283 Bradley \& Co., "Historiscope Lecture," 4.

${ }^{284}$ Ibid. The elm tree became famous as the Shackamaxon Elm, marking the founding of an important city, Philadelphia, and symbolizing the centralization of government that is conceived as having exceptional foundations of fairness, peace and justice. "Penn Treaty Elm" Haverford College Arboretum https://www.haverford.edu/arboretum/collections/penn-treaty-elm 
persecuted Quakers."285 It also reinforced the political foundations of religious freedom for this new nation built by the Pilgrims of New England in scene seven and added another, the idea that all persons were equal before God. The "holy experiment" the Historiscope script referred to and the large document the image shows, were familiar to the audience from accounts in any number of American history textbooks and McGuffey Readers. Audiences of the Historiscope performance would have understood why the document was so prominent in the visual image: because it represented qualities considered to be unique characteristics of the American form of government. ${ }^{286}$

However, the image made it clear to nineteenth-century audiences that these unique characteristics rested firmly on the foundations of trade and commerce. Strewn in the foreground of the image are casks, bales and trunks, symbols of trade. William Penn wears, not Quaker dress as related in, for example, McGuffey's Readers accounts, but instead the green coat of an English eighteenth-century merchant, even though he is a Quaker and the event takes place in the seventeenth century. ${ }^{287}$ At the time of the treaty, 1682, imperial trade policies of Britain benefited both Britain and the American colonies in a two-way exchange.

\footnotetext{
285 Bradley \& Co., "Historiscope Lecture," 4.

${ }^{286}$ Just to list a few: William H. McGuffey, "Lesson LXVI," McGuffey's New Fifth Eclectic Reader: Selected and Original Exercises for Schools (Cincinnati and New York: Van Antwerp, Bragg and Co., 1857), 226-227; William H. McGuffey, McGuffey's Fifth Eclectic Reader: 1879 ed. / with a foreword by Henry Steele Commager (New York: New American Library, 1962, 103. S.G. Goodrich, A Pictorial History of the United States with Notices of Other Portions of America North and South (Philadelphia: E.H. Butler and Co. 1867), 120.

287 McGuffey, McGuffey's Fifth Eclectic Reader, 1879 ed., 103.
} 
Although the placement of scene ten, Roger Williams Pleading with the Sachem of the Narragansett 1632, after scene nine, the Treaty of William Penn with the Indians 1682 does not make chronological sense, it did make logical sense since it brought the story of the development of what were considered to be America's exceptional political principals to a proper conclusion. (figure 4.11) This scene completed the progression of government from that of directed by the king in the mother country viewed in scene five in Jamestown, to government entirely in the hands of the people created by Roger Williams in Providence, Rhode Island viewed in scene ten, and a government sanctioned by God. The Historiscope scene presented Roger Williams as another man of action, a founding father. The script informed the viewer: "Roger Williams was a Puritan preacher in Salem, but having come to entertain too liberal views he was sentenced to be banished to England."288 Continuing the story, the script lets the audience know that, being exceptional, he avoided his sentence, fled to the wilderness, and formed a new community founded on "true democracy," and "in acknowledgment of the Hand which had guided his wanderings, he names the city Providence."289 In demonstration of his belief in peace and justice for all, Williams was shown imploring the sachem of the Narragansett not to ally his group with other Indians in order to protect the very Massachusetts Puritans who had banished him, exhibiting the distinct American national ideal, the willingness to negotiate for peace.

The Historisocpe origin story introduced, in the first ten scenes, descriptions of the earliest stories of America's emergence. They took place in three important

288 Bradley \& Co., "Historiscope Lecture," 4. 289 Ibid. 
geographical regions, the west, the south and the north and construct settlement histories for those regions to create a comprehensive narrative of who all these people are and how they came to be. The narrative presented these colonists as English, Protestant and not Catholic, men who are industrious, enterprising and persevering. But, the Historiscope scenes also made clear there were differences among these Englishmen along a north/south divide.

Envisioning common interests, the idea of nation

The first ten scenes I have just discussed represented a world perceived to be at peace, but the remaining fifteen images of the Historiscope represented conflict. The tension that this organization created provided the pivot point that drove the origin narrative to the ultimate divinely ordained conclusion: sovereignty. ${ }^{290}$ This pivot point was achieved by the placement of two events that stepped out of chronological order. Both of these scenes visualized war preparation, scene eleven with the building of defensive palisades during King Philip's War (1675-1678) and scene twelve with the building of a blockhouse for offense and defense during the French and Indian War (1754-1763). (figures 4.12 and 4.14) This careful choice of scenes and their organization helped move the narrative developed in the founding of New York City in scene eight, the founding of Philadelphia in scene nine and the

290 Anderson, Imagined Communities, 7. As Benedict Anderson states in Imagined Communities, "... all nations dream of being free .... The gage and emblem of this freedom is the sovereign state." 
founding of Providence in scene ten, from a narrative of colonists who negotiated for peace, to a narrative of war. ${ }^{291}$

Enactment of principles of self-government allowed these Englishmen to navigate relations with the "savages" through negotiations (City of New York in scene eight, William Penn in nine, and Roger Williams in ten), but when it became clear that the Indian did not understand that their demise was inevitable, Englishmen readied themselves for two wars. These two wars established English supremacy in North America (King Philip's War in scene eleven and the French and Indian War in scene twelve), but more importantly, allowed the colonies to come together as one with common interests. The typical belief in nineteenth-century America that the "Indian problem" was solved with their "defeat," was given visual proof in the Historiscope. The Landing of Columbus in scene two through Roger Williams Founding Providence in scene ten showed white men finding a new continent, changing the appearance of all things with the industry and arts of civilization, and using exceptional principles of governance, negotiating with "savages," all actions ordained by God. ${ }^{292}$ With two Indian Wars depicted in scenes eleven and twelve, the "savages" were defeated and then disappeared from the origin narrative altogether. American history textbooks of the times supported this view. Benson Lossing's A Primary History of the United States. For Schools and

291 This ideal is made visual in the Great Seal, adopted by Congress in 1782, which includes a Bald Eagle that holds in the talons of one foot thirteen arrows and the talons of the other, thirteen olive branches. The head of the eagle is turned toward the talons with thirteen olive branches, symbolizing the nation's strong desire for peace but readiness for war.

292 Lossing. A Common History of the United States from the Earliest Period to the Present Time, 9. 
Families, published in 1867, is a good example: "Unless you live beyond the Mississippi river, you seldom see any of [the copper-colored people] now. They are nearly all beyond that river, and are becoming fewer every year."293

\section{Quest for Independence}

The text and images in scenes thirteen through the end of the panorama, from Wadsworth Hiding the Connecticut Charter through Lord Cornwallis Surrendering at Yorktown, worked together to signify a radical break with the past. One way this was done, the script text gave colonists a new identity to show they were working for national interests now. The script text no longer referred to the colonists as Englishmen. Scene thirteen (Wadsworth Hiding the Connecticut Charter) text referred to them as "the Connecticut people," scene fourteen (Boston tea party) text used "American colonists," scene fifteen (Battle of Lexington) "a little band of seventy minute-men," and scene sixteen (Battle of Bunker Hill) text used for the first time "Americans." 294 (figures 4.15 - 4.18) The images did this by showing an escalation in conflict from deceit when Wadsworth hid Connecticut's charter from the British in scene thirteen to the "First Blow for Liberty" in scene fifteen. The American origin story narrative enshrined the actions of only white men as bringing about the political guarantees and centralization of power necessary for the formation of a nation, and essential requirements for the workings

${ }^{293}$ Lossing, A Primary History of the United States, 10.

294 Bradley \& Co., "Historiscope Lecture," 5-6. 
of a capitalist economic system. ${ }^{295}$ A centralized approach to finances and administration of this new nation was symbolized by Independence Hall, pictured in scene twenty-one. (figure 4.25) The requirement of political guarantees was symbolized in the British surrender by the turning over of a sword, pictured in scene twenty-five. (figure 4.29)

The Historiscope connected the latter half of the narrative, the quest for independence, to the earlier half, the quest for self-government and economic independence, by including scenes that bridged the two halves. Colonial subterfuge illustrated in scene thirteen chronologically took the narrative back in time to remind the viewer this quest for self-government dated all the way back to 1686 with the hiding the Charter of Connecticut granted by a British king in what became a symbol of American independence, the Charter Oak. (figure 4.15) The Boston tea party scene (scene fourteen) reminded the viewer the quest for economic independence dated back to the Treaty of William Penn in 1682 (scene nine). (figure 4.16) Britain abandoned by 1763 the mercantilist policy referenced in that scene of trade and commercial negotiation, imposing duties and taxes on American commerce, leaving colonial and British relations in constant crisis. The Historiscope made clear that Britain's failure to understand that the colonists wanted selfgovernment and economic independence led to the Boston tea party. The Historiscope scene shows colonists cheering in the foreground while chests of tea are thrown into Boston Harbor in the background. The script states: "Owing to the resistance of the colonies, Parliament in 1770 abolished all duties imposed by the

295 Habermas, The Structural Transformation of the Public Sphere, 17. 
act of 1767, except a very slight duty on tea, which was retained in order to secure the assent of the colonies to the principle of taxation. On this point the colonists were not understood, as it was against the principle and not the amount of taxes, that they were contending."296 Image and text collaborated to establish that this act of sabotage was an act in which the colonies defined their common interests, worked for self-government with the assent of the majority, and demonstrated their desire for economic independence. The next sentence in the script established the inevitability of armed rebellion: "This act led the British Parliament to adopt measures of retaliation until all attempts at reconciliation having proved fruitless the colonists were driven to the dread alternative of war."297

The scenes that comprise the quest for independence introduced a roll call of white men whose daring feats exemplified the characteristics the virtuous citizen should strive to emulate, and taught what the citizen could and could not do. In scene thirteen, William $[s i c]$ Wadsworth, dressed to look like a swashbuckling French musketeer complete with drawn sword rather than the assemblyman from Connecticut that he was, hides the Connecticut charter in defiance of English rule.298

\footnotetext{
296 Bradley \& Co., "Historiscope Lecture," 5-6.

297 Ibid, 6.

298 History textbooks of the nineteenth century record the name as Joseph Wadsworth, not William. Since I have not been able to find an image like this in any popular sources of the time, it is possible that Milton Bradley \& Co. created an image that would emphasize this founding father as a man of action. Alexander Dumas published his popular novel The Three Musketeers in 1844. Although nineteenthcentury history textbooks always included an account of this event and images of the Charter Oak often accompanied these accounts, I have found only one image of Wadsworth hiding the charter and he was dressed as an eighteenth-century gentleman. This image is located in Samuel Goodrich's A Pictorial History of the Western World published in 1848. Samuel G. Goodrich, A Pictorial History of the
} 
In scene sixteen, General Joseph Warren gives his life in the Battle of Bunker Hill, and in scene eighteen, George Washington takes charge of the Continental army. (figures 4.18 and 4.22) In scene nineteen, two expeditions of patriots attack Quebec "in order to secure to the colonists the Province of Canada."299 (figure 4.23) In scene twenty, Colonel William Moultrie successfully commands a garrison to defeat an attacking superior land and sea British force. Sergeant William Jasper replaces the Stars and Stripes with bombs bursting in air. ${ }^{300}$ (figure 4.24) In scene twenty-two, loyal soldiers struggle through hunger, cold and disease during the long, hard winter at Valley Forge as General Washington endures the same deprivations along side his men, and in scene twenty-three, General Putnam plunges down a precipice to divert British fire from his men. (figures 4.26 and 4.27) In scene twenty-four, ordinary militiamen uncover treason by the traitor Benedict Arnold, revealing for the viewer what constituted the worst possible crime, putting personal gain above the interests of the nation. (figure 4.28)

The traits the viewer saw in action in the Historiscope were industriousness, perseverance, egalitarianism, and loyalty. General Washington is shown as embodying all of these characteristics. Featured in three scenes total, this was more than any other man of action. The Historiscope presented him as every source in the nineteenth century did, a larger than life hero who stood taller than any other

Western World A Pictorial History of America. Embracing both the Northern and Southern Portions of the New World (Hartford: House and Brown, 1848), 443. ${ }^{299}$ Bradley \& Co., "Historiscope Lecture," 6.

${ }^{300}$ However, the stars and stripes flag was not chosen by the Second Continental Congress until June 14,1777. As a consequence, June 14 is celebrated, even today in 2020, as "Flag Day." 
man and above petty bickering and disputes. ${ }^{301}$ He rode into scene eighteen on a white horse with a flourish of his sword, indicating that he took charge of the Continental Army as Commander-in-Chief. (figure 4.22) In an art tradition of leaders represented on horseback that dated back to Ancient Roman times, he appeared in the origin story as the supreme leader, the Father of this nation. The script makes clear he inherited an army unfit for service, and yet the viewer knows the Americans won the war. The only possible conclusion could be that Washington's exemplary leadership ensured this triumphant outcome. He performed as a paragon of virtue in scene twenty-two at Valley Forge, and in scene twenty-five at Yorktown. (figures 4.26 and 4.29) He became a framework from which to hang all the virtues to be emulated. The script for the "gloomy Winter at Valley Forge "(scene twenty-two) corroborates this portrait of George Washington:

It was while Washington was struggling against every obstacle to keep his army together through the gloomy Winter at Valley Forge, that an attempt was made to remove him from the chief command. When this intrigue became known, so great was the storm of popular indignation that burst forth from State legislators and the people, that the instigators of the movement were afraid to acknowledge the part they had taken in it. 302

In the Battle of Lexington and the Battle of Bunker Hill, scenes fifteen and sixteen, the Historiscope commemorated the "profound rupture with the existing world" necessary for the formation of a nation. (figures 4.17 and 4.18) The script called it "the first blow for liberty." ${ }^{303}$ The scenes pictured the transformation of

301 Tyack, David B., "The Conservative Persuasion: American Textbooks in the Nineteenth Century," in Turning Points in American Educational History, ed. David B. Tyack (New York: John Wiley and Sons, 1967), 182.

302 Bradley \& Co., "Historiscope Lecture," 7. 303 Ibid, 6. 
death into continuity and contingency into meaning that the idea of nation made possible, just as the Myriopticon did in Sixth Massachusetts Regiment Attacked in Baltimore in scene three and Murder of Colonel Ellsworth in scene four in the narrative of the Great Rebellion. ${ }^{304}$ Scene fifteen, the Battle of Lexington, confronts the viewer with armed revolt and lifts one minute-man to the apex of a triangular composition, representing a male citizen willing to lay his life on the line for this idea of nation, as fellow male minute-men lie wounded or dead at his feet. Fatality was transformed in the script into "first blood," presenting the deaths of the minutemen as part of an unbroken process of forming a nation. The first official battle of the Revolutionary War was presented in scene sixteen, the Battle of Bunker Hill. (figure 4.18) The scene served the added purpose of introducing the first American officer who made this ultimate sacrifice, General Joseph Warren, in what the script entry called "the first actual battle of the war," a war the Historiscope lecture implied would have many more battles and many more deaths. The composition created an energy through its dominant ascending diagonal from right to left that moves the viewer's eye to the stars and stripes, in order to connect this death to a symbol of the new nation. ${ }^{305}$ Viewers would have been very familiar with this image. The composition was copied from an original oil painting by John Trumbull, who sold the engraving rights to this painting. (figure 4.19) The image was reproduced in almost all the illustrated history textbooks of its time. (figure 4.20)

304 Anderson, Imagined Communities, 11.

305 The national flag, the stars and stripes, was not decided on until the Flag Act of 1777. The Historiscope image has substituted the stars and stripes for the banners that appeared in Trumbull's painting, The Death of General Warren at the Battle of Bunker's Hill, June 17, 1775; many versions of this painting were created by him from the late 1700 s into the early 1800s but none include the Stars and Stripes. 
The Battle of Lexington (scene fifteen) was the last of the only three scenes that women appeared in. Women are pictured in the margins of this battle, as a part of the foundation of the pyramid, supporting the fallen men. This scene, like Pocahontas Saving Captain John Smith in scene six and Landing of the Pilgrims in scene seven, conformed to the Victorian construction of the feminine by allowing these women only a supporting role to help men fulfill their destinies. Since women were constructed as closer to nature, they appear in this scene because to fight against the tyranny of Britain was considered to be an act of nature.

To underscore the importance of sacrifice, the Historiscope presented in scene seventeen the perfect monument to the idea of nation, a cenotaph: Bunker Hill Monument. ${ }^{306}$ (figure 4.21) The script described it as a central focus in Boston: “... which is of granite two hundred and twenty feet high, and is one of the first objects that is seen on approaching the "Hub'." ${ }^{307}$ By using the term "Hub" to denote Boston, the script referred to the fact that Boston was the moral and cultural hub of the nation in the mid-nineteenth century, and as such the cenotaph completed in 1843 embodied the idea of that nation by turning death into immortality and uncertainty in life into a way to enunciate national character. ${ }^{308}$ The well-known statesman and orator, Daniel Webster, eloquently enunciated what that national character was at the completion of the Bunker Hill Monument June 17, 1843:

306 Anderson, Imagined Communities, 9.

${ }^{307}$ Bradley \& Co., "Historiscope Lecture," 6. The "Hub" was a nickname for Boston, coined first by Oliver Wendell Holmes in a series of satirical articles in The Atlantic Monthly entitled "The Autocrat at the Breakfast Table" in 1858. The cornerstone for the monument was laid in 1825 and construction progressed in fits and starts, as a commission of private citizens raised the money to complete it. Daniel Webster gave the address at the ceremony to commemorate its completion June 17, 1843. ${ }^{308}$ Cremin, American Education, 33; Anderson, Imagined Communities, 9-10. 
"Today, it speaks to us.... Its speech will be of patriotism and courage; of civil and religious liberty; of free government, of the moral improvement and elevation of mankind; and of the immortal memory of those who with heroic devotion have sacrificed their lives."309

The final scene of the Historiscope, The Surrender of General Cornwallis at Yorktown, brings the war to its divinely ordained conclusion. (figure 4.29) In the scene the Commander of British forces hands over of his sword in defeat to the Commander-in-chief of the American forces at the end of the Battle of Yorktown in what the script states "substantially ended the Revolutionary War."310 Washington, the Father of the American nation, receives the sword of surrender from the hands of British General Cornwallis in a scene that symbolized for the American nation that the shackles of subjugation by British rule had finally been broken. Although the pictured scene never happened, it is shown as happening because this iconic gesture embodied the radical break with the past that was perceived to have happened, allowing the new American nation to spring forth fully formed.

\section{Conclusion}

Both the Historiscope and Myriopticon tell narratives whose divinely ordained conclusions must come about by breaking the chains of slavery. In the Historiscope's origin story, forming the nation required ending the enslavement of

\footnotetext{
${ }^{309}$ Daniel Webster, Address. Delivered at Bunker Hill, June 17, 1843, on the completion of the Monument (Boston: Press of T.R. Marvin, 1843), 8.

310 Bradley \& Co., "Historiscope Lecture," 8.
} 
the American colonists by British rule. ${ }^{311}$ In the Myriopticon, preservation of the nation required vanquishing the Southern slave system. This was a view the audience would have been familiar with from popular media of the time, for example in an editorial in Harper's Weekly entitled "A Political Catechism for Children" that appeared early in the Civil War (September 7, 1861):

This war, my dear, is the last dying struggle of slavery as a political power. If you have read history aright, you must have learned that all great and powerful systems or bodies die hard. The Roman Catholic hierarchy, the divine right monarchies, the feudal oligarchies, all struggled very hard before they gave way to common sense and the rights of the people. Just so slavery, as an element of political power, is now making its last dying struggle, and you may depend upon it, it will fight to the last. But if you have read your Bible right, and have the true instincts of a free-born American boy in you, you can not doubt how the contest will end. ${ }^{312}$

The Historiscope was one of many forms of popular media that served to inform, inspire and educate the citizenry with "artistic" images in post Civil War Reconstruction that defined what a united nation looked like and how citizens of that nation could support the perfection of that nation. The very object itself was an example of the technological innovation considered important to create a more perfect nation. The materials the Historiscope was made of, pasteboard and chromolithographed images, were new industrial products used in the manufacturing process by Milton Bradley \& Company, and that industrial capitalist system also allowed for its mass production, distribution and advertisement. The performance of the origin story taught the importance of agency and participation by its operators, orators and observers, attributes considered necessary for citizens

311 Joyce, The First U.S. History Textbooks, 238. 312312 "A Political Catechism for Children," Harper's Weekly, 562. 
of the United States to properly fulfill their role moving the nation forward to perfection.

As the lights came up at the end of the performance in the parlor theater, the audience politely applauded, secure in their knowledge that "these pictorial histories ... are the best possible educators on the prominent points of historical interest." (Milton Bradley \& Co. advertisement) This origin story was part of the broad cultural education charged with facilitating a unified American society firmly grounded in the Northern capitalist economic system. By being performed over and over again within the confines of the family, the Historiscope took on a life of its own as an authoritative source of knowledge, shaping ideas and beliefs, an unquestioned authority. ${ }^{313}$ This narrative came to be considered the reality it purported to describe, treated as if it embodied the "true values" identified by the miniature panorama as representing America. These values were internalized and believed, working as a filter for what the performers and viewers were able to see and understand. The values they learned shaped the behaviors considered appropriate for the virtuous citizen in order to create an independent yet loyal citizen. ${ }^{314}$

What "true values" would the young performers and viewers of the Historiscope origin story learn? That it is better to act in the public interest than to act in private interest. That white males played active, important roles in forming and administering the nation. That women were present but played only supporting roles in this society. That indigenous peoples existed but they did not have interests. All of these scenes collectively reveal that the nation was conceived

313 Joyce, The First U.S. History Textbooks, 8.

${ }^{314}$ Cremin, American Education, 5. 
as a "deep horizontal" fraternity. Only white men of European ancestry could be heroes since no women, or men of African, Mexican, Native American or any other ancestry other than northern European, have agency. Only white men were created equal, although Southern white men's work ethic may be suspect. Instruction in the behaviors that help Americans fulfill their prescribed roles fostered cultural unity and stability, and cultural unity and stability was good for business. 


\section{Chapter 5: CONCLUSION}

Just as all nations create origin stories, so did businesses, and Milton Bradley \& Company was no exception. The origin story was told in two publications. One was the book It's All in the Game, published in 1960 by the then president of Milton Bradley \& Company, James J. Shea, to celebrate the one-hundredth anniversary of the founding of the company. The other was a published address the person who succeeded his father as president, James J. Shea, Jr., gave in 1972 to the Newcomen Society, an organization created to give recognition to origin stories of successful businesses. ${ }^{315}$ The origin story told in these two publications established an identity for Milton Bradley \& Company, relating how the company came to be, what the company stood for, and what principles made the company a good citizen of the nation. These two chronicles highlighted the success of the Milton Bradley \& Company model of citizenship. It was utilized in The Checkered Game of Life, the Historiscope and the Myriopticon in the mid-nineteenth century and continued to be dominant through the mid-twentieth century.

Much of what we think we know about the game inventor and manufacturer Milton Bradley, and the company that bears his name, comes from It's All in the

315 The Newcomen Society in North America (1923-2007) promoted free enterprise by honoring businesses that were successful, publishing histories of those successes (like "The Milton Bradley Story"), and encouraging research and writing in histories of successful businesses. 
Game and "The Milton Bradley Story." They have become the de facto source of information because scholars have found little other information. Both sources were written for a popular, not scholarly, audience; therefore neither is footnoted, there are no bibliographies, and no indexes. Shea wrote in It's All in the Game that Milton Bradley "painstakingly" kept a diary during much of his life, but scholars have found that although Milton Bradley's papers were kept in the company archives up to the 1960 s, by the 1970 s requests for access were turned down. ${ }^{316}$ In 1984, Hasbro bought out Milton Bradley \& Company; no one at Hasbro knew where the papers were, and when American historian, Jill Lepore, searched in Hasbro's archives in 2006, she found nothing about Milton Bradley or the company. She tried to locate the papers through Bradley's descendants, but nothing turned up.

Scholars, however, quote information from It's All in the Game as if it was "true fact," but given that the sources these "facts" come from are part of an origin story, scholars should be aware that these "facts" were selected and manipulated to tell a story with a particular point of view.

These two chronicles for the origin story of the company, It's All in the Game and "The Milton Bradley Story," use the founder, Milton Bradley, as a vehicle to establish the company's identity. Milton Bradley was described as a citizen who thought and acted for the greater good by persevering, and being honest, thrifty, brave, an individualist who 'took no stock in such words as 'fame' and 'fortune.' ... But he liked and understood that word 'opportunity,' which held out a promise to

316 Shea, It's All in the Game, 19; Lepore, The Mansion of Happiness, 199 footnote 6. 
one who believes in himself and his skill - and wanted to work hard."317 These were the very virtues that ensured success in The Checkered Game of Life, and were attributed to the founding fathers in the origin story of the United States presented in the Historiscope, and exhibited by the North in the story of the Great Rebellion presented in the Myriopticon.

The chronicles described the company founder as "gifted with true Yankee ingenuity." ${ }^{18}$ Milton Bradley was declared a "Yankee" to establish the company's business credentials by connecting him to the regional characteristics of hardworking, frugal business acumen constructed in the nation's origin story for New Englanders. Shea defined a Yankee as "one of English descent whose forebears had been living in New England for a long time - often a couple of centuries," ensuring potential customers connected the company and its products to the power center of the nation. It's All in the Game declares that Milton Bradley's descendants came to New England from England centuries before, just as the nation's "founding fathers" had. ${ }^{319}$ The decoration of the boxes of all three parlor games and the game board of The Checkered Game of Life prominently display the location of the company as Springfield, Massachusetts, to ensure the customer knows that the company is located in New England. Shea connected Bradley to thrift: "It's erroneous, however, to think of Bradley as a fumbler lacking in business acumen. He shrewdly knew the value of the Yankee dollar." 320

317 Shea, It's All in the Game, 17, 25.)

${ }^{318}$ Shea, Jr., "The Milton Bradley Story," 9.

${ }^{319}$ Shea, It's All in the Game, 22.

320 Ibid, 41. 
A discrepancy between the two chronicles in the origins of The Checkered Game of Life served to identify the company as a modern capitalist industrial business. To make it clear that Milton Bradley, and therefore the company, were modern capitalists, the account in It's All in the Game (1960) described him as a speculator: "Although Bradley was vigorously opposed to gambling in any form and never, as far as can be learned, wagered a single penny on a turn of any wheel of chance, he was a gambler. Like every creator and innovator, he gambled with ideas and time when he set out to introduce a variety of games to Americans." 321 However, this story by 1972 had been streamlined to describe Milton Bradley's actions as those of a shrewd entrepreneur who recognized a good opportunity when he saw it, and bought the game that an inventor brought to him already named, putting his company on a firm financial footing at a time when the presses were idle and "potential bankruptcy threatened." 322

Both versions celebrated the company's success in the industrial capitalist system of the nation. They showed, through the actions of the founder, that the company could use The Checkered Game of Life to combine the new technological knowledge of pasteboard and chromolithography with an idle industrial plant in need of a product and help the company turn the corner on an economic downturn. Through the founder, it was made clear that the company knew opportunity when it presented itself. Bradley knew that in a capitalist economy the man who really profited from technical knowledge was neither the craftsman nor the inventor but the entrepreneur like him who could speculate with capital and had the ability to

321 Shea, It's All in the Game, 64.

322 Shea, Jr., "The Milton Bradley Story," 10. 
combine new technological knowledge with the specific needs of industry. ${ }^{323}$ What was good for the free enterprise system was good for the nation.

Through the founder, the two origin chronicles establish Milton Bradley \& Company as a model citizen. The model citizen was defined through the virtuous characteristics developed for the founder, Milton Bradley. Virtuous citizen Bradley guarded liberty because he believed his individual interests were best served when he safeguarded the common interests of the whole. ${ }^{324}$ The Checkered Game of Life, the Historiscope and the Myriopticon, educated their participants and audiences in the moral behaviors this required. These moral behaviors were developed in the origin story of the nation told in the Historiscope, and made the instruments for success in The Checkered Game of Life.

Milton Bradley \& Company manufactured the three parlor games I chose to study just before and after the Civil War. The visual images and pedagogy of these parlor games show a change pre- to post- Civil War from high contrast images with a didactic delivery in The Checkered Game of Life to images connected to fine art with expressive deliveries in the Historiscope and Myriopticon. This change echoed the change found in ephemeral Protestant publications such as those mass produced by the American Tract Society. ${ }^{325}$ However, the model of citizenship did not change. The model was based on the combination of skill and judgment exhibited by the model citizen Bradley, presented in the origin stories for the company. According to these chronicles, he utilized these characteristics to accumulate property, therefore

323 Burns, Success in America, 169.

${ }^{324}$ Earl J. Hess, Liberty, Virtue, and Progress: Northerners and Their War for the Union (New York and London: New York University Press, 1988), 11.

325 Morgan, Protestants and Pictures, 268. 
ensuring progress and the perfection of the United States. His skills and judgment were guided by values informed by evangelical Protestantism and revered in the American origin story, and by telling that story and constructing a framework of success based on those values, the Historiscope, the Myriopticon and The Checkered Game of Life become guardians of those ideals. ${ }^{326}$ These social ideals constituted the American tradition. All three parlor games instructed American citizens that it was their duty to protect that tradition. ${ }^{327}$ The ideal American citizen depicted in all three parlor games was a white man of Northern European ancestry, his virtuousness informed by Protestantism, and "gifted with true Yankee ingenuity."328 Therefore, self-interest and morality were considered to be the two important operating forces that accounted for national and personal progress. ${ }^{329}$ The American tradition legitimated the individual's right to prosper. This could lead to positive outcomes such as developing new machines, discovering and developing new resources, creating new products, opening new markets, all depicted in the Myriopticon as reasons for the triumph of the North over the South in the Civil War. But it was believed that such activity could also lead to acquisitiveness, out-ofcontrol speculation, and thievery. It was felt that the progress of the economy could seduce the accumulators to forget the common good, degrade self-control and encourage aggressive individualism.

\footnotetext{
${ }^{326}$ Ruth Miller Elson, Guardians of Tradition: American Schoolbooks of the Nineteenth Century (Lincoln: University of Nebraska Press, 1964), 257.

327 Ibid, 340.

${ }^{328}$ Shea, Jr., "The Milton Bradley Story," 9.

${ }^{329}$ Hess, Liberty, Virtue, and Progress, 120.
} 
Lack of self-control resulted in violation of the law, and all three parlor games reserved the severest penalties for breaking laws. Breaking laws represented an inability to balance common good with self-interest. Rules are important in all parlor games and the 1871-2 Work and Play Annual of Home Amusements and Social Sports, published by Milton Bradley \& Co. filled an entire page with instructions on how to read the rules in "Learning to Play New Games." The Checkered Game of Life reserved a severe penalty for landing on CRIME: the player was sent to prison at the bottom of the board and lost of a turn. But the severest penalty was reserved for breaking the laws of nature: landing on SUICIDE resulted in the player being thrown out of the game. If people abandoned moral restraint and broke the laws of the nation, working only for the good of themselves or as cliques rather than for the good of the nation, then anarchy reigned, as was pictured in the Myriopticon scene two at Fort Sumter, scene three on the streets of Baltimore, and scene four in a hotel in Alexandria, Virginia. The Myriopticon showed that when the South rebelled and worked only for its own good, the result was a civil war and ultimate disaster.

How does a citizen learn to put the common interest of the nation before selfinterest? All three parlor games I studied trained players in orderly public participation and work beyond the family that created national identity. ${ }^{331}$ These parlor games developed and facilitated "agency and participation" in the larger American democratic society and encouraged and reinforced what the educational historian Lawrence A. Cremin (1925 - 1990) called a "utilitarian tendency in

330 Bradley \& Co., Work and Play, 6.

331 Cremin, American Education, 495. 
American life and thought." ${ }^{332}$ In education, that utilitarian tendency manifested itself, not in a focus on ideas for their own sake, but as tools to better everyday life. Therefore, parlor games were not just developed to be entertaining, but were first and foremost "moral and instructive" tools for moral improvement and personal advancement to fulfill the roles citizens were expected to play in the life of an industrial capitalist nation.

Parlor games, then, became the perfect vehicle to teach the primary value to be developed in youth, love of the American nation, a nation of law and order, and to shape participants' and audience's own identity as citizens. In 1960, Milton Bradley \& Company re-made The Checkered Game of Life in celebration of their onehundredth anniversary. The Game of Life retained the same model of citizenship where virtues were instruments of success but added "some twentieth-century ideas that might amaze the founder." 333 However, the game still allowed players to construct a narrative of their life, in essence form their identity, which is part of any origin story. The Game of Life was instantly successful in 1960 and beyond, demonstrating how much a game facilitating identity making still resonated with customers one hundred years later.

The Checkered Game of Life and The Game of Life both gave the individual player a personal stake in the outcome of the game by giving them choices. This play action mimicked self-government, a system of government the national origin story told in the Historiscope makes a cornerstone of national identity. A

332 Cremin, American Education, 496.

333 Shea, It's All in the Game, 278. The chronicle explains: "At a crucial point in the game, for example, a player can borrow money - and has a chance to win a million dollars." 
democratic form of government relied on egalitarianism and individualism. Citizens with the opportunity to control their own lives, to choose, for example, their livelihood, what to do with their pay, and to have a voice in running the country, needed to know they had the same chance of success as everyone else..$^{334}$ Egalitarianism and individualism worked together on the game board of The Checkered Game of Life too, given that every player started the game on the same square, Infancy, played by the same rules, and were allowed to make individual choices that promoted personal advancement to win. The player who exercised the best strategy won. Americans believed their system of government allowed everyone who worked hard and used their intelligence to move forward. The civil rights activist, scholar and writer W.E.B. DuBois (1868-1963) revealed how pervasive the acceptance of this belief was in the 1870s when he later wrote about growing up in Massachusetts:

My general attitude toward property and income was that all who were willing to work could easily earn a living; that those who had property had earned it and deserved it and could use it as they wished; that poverty was the shadow of crime and connoted lack of thrift and shiftlessness. These were the current patterns of economic thought of the town of my boyhood. (from Dusk of Dawn: An Essay Toward an Autobiography of a Race Concept, 1940, p. 18) ${ }^{335}$

After the Civil War, with the demise of the Southern slave economy and the emancipation of four million slaves, post-war conditions required a different ideology and social system. The ideology needed to acknowledge liberty was very complex because it must apply to all people and all interests and industries in the

${ }^{334}$ Hess, Liberty, Virtue, and Progress, 6.

335 Robert T. Handy, A Christian America: Protestant Hopes and Historical Realities, second edition (New York and Oxford: Oxford University Press, 1984), 66. 
nation, and the social system needed to incorporate skin color and gender into egalitarianism. To accomplish this required an activist government. Instead, most Americans refused to believe the necessity of ideological and social change. As the Myriopticon made clear, the Civil War was fought to preserve an economic system, not to forge a social system with a radically different ideology. The post Civil War years of Reconstruction were dominated socially and economically by individualism with only the presumption that everyone was equal.

Aristotle remarked that people construct education around their belief of what the good life is. ${ }^{336}$ The Historiscope presented performers and audiences with the same origin story that had been conceived and told since the earliest years of the formation of the nation, instead of calling for a radically different ideology founded on a more complex conception of liberty for all. The Myriopticon presented them with the triumph of industrial capitalism and the march of progress it facilitated, educating every boy in the audience in the active roles he could play in the nation when he grew up. The Checkered Game of Life educated participants in the virtues that were believed to develop model citizens. Women, however, did not take active roles, but were given only the liberty considered suitable to their constructed gender. They were educated to stay home, placed in charge of the moral education of the virtuous family, and consumption to keep the wheels of the industrial capitalist economy growing. Parlor games became a product women could buy to facilitate a middle-class vision of the good life in which self-interest was coupled with the virtues believed to prevent destruction of individual moral character and to

${ }^{336}$ Cremin, American Education, 487. 
accommodate the common good so that economic growth would not be perceived as morally objectionable.

The performance of The Checkered Game of Life, the Myriopticon and the Historiscope in the parlor surrounded by family and friends defined what northern, white middle-class men of America believed to be the national identity. But where does the promise of success incorporated in the play action of The Checkered Game of Life or the occupations illuminated in the Myriopticon or the provisions of liberty for all inherent in the origin story presented in the Historiscope leave all those citizens of America who were not men or white or middle-class? The origin story narrative told could instead insist on a story that realizes the promise of success and liberty for all that is inherent in all of these parlor games. Instead of a story of national identity defined by white virtuous men and the carefully chosen events that showcase their actions, there needs to be a different way of telling of origins. The way the story was told in the nineteenth century marginalized everyone who was not white and male, thereby estranging national identity from the promise inherent in the story of liberty for all. In a better world, the origin story could merge national identity with the promise of liberty for all by making the events and people who inhabit the story serve the promise inherent in those events. 


\section{APPENDIX ONE}

Sources for images in The Myriopticon A Historical Panorama of The Rebellion - all sources come from the illustrated news magazine Harper's Weekly. A Journal of

\section{Civilization.}

Scene one: "Entry of Major Anderson's Command into Fort Sumter on Christmas Night, 1860." Harper's Weekly V, no. 211 (January 12, 1861): 25.

Scene two: "Bombardment of Fort Sumter by the Batteries of the Confederate States, April 13, 1861." Harper's Weekly V, no. 226 (April 27, 1861): 264-265.

Scene three: "First Blood - The Sixth Massachusetts Regiment Fighting Their Way Through Baltimore, April 19, 1861." Harper's Weekly V, no. 227 (May 4, 1861): 283.

Scene four: "The Murder of Ellsworth." Harper's Weekly V, no. 233 (June 15, 1861): 369.

Scene five: “The Battle of Bull Run, 2 PM July 21, 1861.” Harper's Weekly V, no. 241 (August 10, 1861): 504-505.

Scene six: "Return of a Foraging Party to Philippi, Virginia." Harper's Weekly V, no. 242 (August 17, 1861): 518.

Scene seven: “Crow's-Nest Signal Station.” Harper's Weekly VIII, no. 404 (September 24, 1864): 621.

Scene eight: "The Bivouac Fire at the Outposts of Our Army of the Potomac." Harper's Weekly V, no. 249 (October 5, 1861): 632.

Scene nine: "General View of Fort Donelson - Sketched by Mr. A.L. Rawson. Harper's Weekly VI, no. 272 (March 15, 1862): 161.

Scene ten: “The Ericsson Battery 'Monitor' Driving Off the 'Merrimac.' Harper's Weekly VI, no. 273 (March 22, 1862): 184-185.

Scene eleven: “The Flag-Ship 'Hartford' Attacked by the Ram 'Manassus' and a FireRaft in the Mississippi.” Harper's Weekly VI, no. 285 (June 14, 1862): 369.

Scene twelve: "On the Mississippi - Porter's Mortar in Action - sketched by Mr. Theodore R. Davis.” Harper's Weekly VI, no. 294 (August 16, 1862): 520. 
Scene thirteen: "General View of the Encampment of the Army of the Potomac at Harrison's Landing - Sketched by Mr. A.R. Waud." Harper's Weekly VI, no. 295 (August 23, 1862): 532.

Scene fourteen: "The Army Telegraph - Setting up the Wire during an Action." Harper's Weekly VII, no. 317 (January 24, 1863): 53.

Scene fifteen: Combines two scenes: "The Battle of Antietam - Carrying Off the Wounded After the Battle - Sketched by Mr. A.R. Waud." Harper's Weekly VI, no. 302 (October 11, 1862): 649. And "Scenes on the Battlefield of Antietam - From Photographs by Mr. M.B. Brady - The Stone Bridge." Harper's Weekly VI, no. 303 (October 18, 1862): 664-665.

Scene sixteen: "The Army of the Potomac - A Sharpshooter on Picket Duty - [From a painting by W. Homer, Esq.]" Harper's Weekly VI, no. 307 (November 15, 1862): 724.

Scene seventeen: "The Attack on Fredericksburg - The Forlorn Hope Scaling the Hill." Harper's Weekly VI, no. 313 (December 27, 1862): 817.

Scene eighteen: "Contrabands Coming into Camp in Consequence of the Proclamation - Drawn by Mr. A.R. Waud." Harper's Weekly VII, no. 318 (January 31, 1863): 68.

Scene nineteen: "Major-General Ulysses S. Grant Before Vicksburg." Harper's Weekly VII, no. 337 (June 13, 1863): 376-377.

Scene twenty: "The Halt - [Drawn by Thomas Nast.]" Harper's Weekly VIII, no. 405 (October 1, 1864): 628.

Scene twenty-one: “General Sherman's Victory - Rebel Prisoners Being Conducted to Atlanta from Jonesborough." Harper's Weekly VIII, no. 405 (October 1, 1864): 629.

Scene twenty-two: "The Sinking of the 'Alabama' off Cherbourg June 19, 1864." Harper's Weekly VIII, no. 395 (July 23, 1864): 465.

Scene twenty-three: 'Marching On!' - The Fifty-fifth Massachusetts Colored Regiment Singing John Brown's March in the Streets of Charleston, February 21, 1865." Harper's Weekly IX, no. 429 (March 18, 1865): 165.

Scene twenty-four: Burning of Richmond - I have not been able to trace this image to Harper's Weekly or to any other source yet. 


\section{APPENDIX TWO}

Sources that contain the images found in The Historiscope A Panorama and History of America.

Scene one: A group of Native Americans.

Benson J. Lossing, Pictorial History of the United States for Schools and Families (New York: Mason Brothers, 1858), 7.

Benson J. Lossing, A Centennial Edition of the History of the United States:

From the Discovery of America to the End of the First One Hundred Years of American Independence (Hartford: Thomas Belknap, 1876), 9.

Scene two, part one: Landing of Columbus.

John Vanderlyn, Landing of Columbus, 1846, oil on canvas; placed in United States Capitol rotunda in 1847.

Engraving appeared on a fifteen-cent stamp in 1869, the first bi-color stamp issued in the U.S. 1870s.

Engraving appeared on the reverse of a five-dollar bank note issued in the

Scene two, part two: Nina, Pinta, and the Santa Maria.

Benson J. Lossing, Pictorial History of the United States for Schools and Families (New York: Mason Brothers, 1858), 30.

Benson J. Lossing, A Primary History of the United States. For Schools and Families (New York: Mason Brothers, 1867), 19.

Scene three: Discovery of the Mississippi by De Soto.

William H. Powell. Discovery of the Mississippi by De Soto, 1853, oil on canvas; placed in the United States Capitol rotunda in 1855.

Engraving appeared on the reverse of a ten-dollar bank note in the 1860s.

Samuel G. Goodrich, The American Child's Pictorial History of the United States (Philadelphia: E.H. Butler and Co., 1865 and 1868), 37.

Scene four: Discovery of the Hudson River.

Charles A. Goodrich, The Child's History of the United States, Revised by A.B. Beard (Philadelphia: Cowperthwait and Co., 1878), 32.

Scene five: Settlement of Jamestown, Virginia.

Benson J. Lossing, Pictorial History of the United States for Schools and Families (New York: Mason Brothers, 1858), 47.

Benson J. Lossing, A Centennial Edition of the History of the United States: From the Discovery of America to the End of the First One Hundred Years of American Independence (Hartford: Thomas Belknap, 1876), 61. 
Scene six: Pocahontas Saving Captain John Smith.

D.W. Kellogg (Hartford) lithographer, Pochahontas [sic] Saving the Life of Capt. John Smith, 1830-1840, lithograph; Historiscope scene not an exact copy, Connecticut Historical Society Collections.

Kelloggs and Thayer (New York City, Hartford and Buffalo) lithogrpahers, Pocahontas Saving the Life of Capt. John Smith, 1846-1847, hand-colored lithograph; Historiscope scene not an exact copy.

Samuel G. Goodrich, The First Book of History For Children and Youth (Philadelphia: Key, Meilke, and Biddle and Boston: Richardson, Lord, and Holbrook, 1832), 71.

Charles A. Goodrich, History of the United States of America; for Use of Schools (New York: Taintor Brothers, Merrill and Co., 1867), 29.

Scene seven: Landing of Pilgrims.

Peter F. Rothermel (1812-1895), The Landing of the Pilgrims on Plymouth Rock, 1620,1854, oil on canvas. Historiscope scene not an exact copy.

Joseph Andrews (1806-1873) engraver, [The Landing of the Pilgrims on Plymouth Rock, 1620] title devised by Library of Congress staff, 1869, engraving. Historiscope scene not an exact copy.

Engraved vignette appeared on reverse of one-dollar bank note 1870-1890, engraving by Charles Burt; Historiscope scene very similar except Mary Chilton is added.

Scene eight: City of New York.

Augustin Herman (c.1621-1686) cartographer and illustrator, Southern Tip of Manhattan, then New Amsterdam, as it appeared under Dutch Colonial government, watercolor, Albertina Collection in Vienna.

Johannes "Joan” Blaeu (1596-1673), Dutch cartographer and engraver; Nieuw Amsterdam op t Eylant Manhattans, 1652, engraving. http://www.geographicus.com/P/AntiqueMap/NieuwAmsterdamManhattan-blaeu1652

Benson J. Lossing, Pictorial History of the United States for Schools and Families (New York: Mason Brothers, 1858), 116.

Benson J. Lossing, A Primary History of the United States. For Schools and Families (New York: Mason Brothers, 1867), 74.

Charles A. Goodrich, History of the United States of America; for Use of Schools (New York: Taintor Brothers, 1867), 55.

Benson J. Lossing, A Common-School History of the United States; From the Earliest Period to the Present Time (New York: Sheldon and Company, 1870), 73.

Benson J. Lossing, A Centennial Edition of the History of the United States: From the Discovery of America to the End of the First One Hundred Years of American Independence (Hartford: Thomas Belknap, 1876), 144. 
Scene nine: Treaty of William Penn with the Indians, 1683.

Benjamin West (1738-1820), William Penn's Treaty with the Indians, 1772, oil on canvas.

John Hall (British engraver 1739-1797) and John Boydell (British publisher 1720-1804), William Penn's Treaty with the Indians, 1775, engraving, Library of Congress Photo, Print, Drawing.

Nathaniel Currier (1813-1888) lithographer, William Penn's Treaty with the Indians when he founded the Province of Pennsya-1661, 1835-1856, hand-colored lithograph, Library of Congress Photo, Print, Drawing.

D.W. Kellogg, Hartford, Penn's Treaty with the Indians, 1837-1840, b\&w lithograph, Connecticut Historical Society Collections.

Samuel G. Goodrich, The First Book of History For Children and Youth (Philadelphia: Key, Meilke, and Biddle and Boston: Richardson, Lord, and Holbrook, 1832), 60.

Samuel G. Goodrich, The First Book of History. For Children and Youth. By the author of Peter Parley's Tales. With sixty engravings and sixteen maps. $16^{\text {th }}$ edition. (Boston: Charles J. Hendee, 1836), 36.

Samuel G. Goodrich, Parley's First Book of History. The First Book of History, for Children and Youth. $4^{\text {th }}$ edition. (Boston: Jenks, Palmer and Co., 1849), 83.

Lambert Lilly, Schoolmaster, The History of New England, Illustrated by Tales, Sketches, and Anecdotes, with Numerous Engravings (Boston: Ticknor and Fields, MDCCCLIV [1854]), 45.

Charles A. Goodrich, History of the United States of America; For Use of Schools (New York: Taintor Brothers Merrill and Co., 1867), 63.

Scene ten: Roger Williams Pleading with the Sachem of the Narragansetts.

Charles A. Goodrich. The Child's History of the United States, Revised by A.B.

Beard (Philadelphia: Cowperthwait and Co., 1878), 27.

Scene eleven: Palisaded house, King Philip's War.

Benson J. Lossing, Pictorial History of the United States for Schools and Families (New York: Mason Brothers, 1858), 101.

Charles A. Goodrich History of the United States of America; For Use of Schools New York: Taintor Brothers Merrill and Co., 1867), 43.

Benson J. Lossing, A Primary History of the United States. For Schools and Families (New York: Mason Brothers, 1867), 67.

Benson J. Lossing, A Common-School History of the United States; From the Earliest Period to the Present Time (New York: Sheldon and Company, 1870), 63.

Benson J. Lossing, A Centennial Edition of the History of the United States: From the Discovery of America to the End of the First One Hundred Years of American Independence (Hartford: Thomas Belknap, 1876), 127 footnote 1.

Scene twelve: Block-house, Kennebec, Maine.

Benson J. Lossing, Pictorial History of the United States for Schools and Families (New York: Mason Brothers, 1858), 157 footnote 4. Historiscope scene not an exact copy. 
Benson J. Lossing, A Common-School History of the United States; From the Earliest Period to the Present Time (New York: Sheldon and Company, 1870), 102. Historiscope scene not an exact copy.

Benson J. Lossing, A Centennial Edition of the History of the United States: From the Discovery of America to the End of the First One Hundred Years of American Independence (Hartford: Thomas Belknap, 1876), 192 footnote 3. Historiscope scene not an exact copy.

Stereoscope card: Fort Halifax block-house, Teconnet, now Winslow, Maine, on a point of land between Kennebec and Sebasticook rivers, built for protections from the French and their Indian allies in 1754. Wikimedia Commons. Same blockhouse but Historiscope scene not an exact copy of the photograph.

Scene thirteen: Wadsworth hiding the Charter of Connecticut.

This is the one Historiscope scene I have found no source for. What are listed below are images of the Charter Oak and some include Wadsworth; the Charter Oak was a popular illustration for history books.

E.C. Kellogg (Hartford) lithographer, The Charter Oak, 1830-1840, b \& w lithograph, Connecticut Historical Society Collections. The Charter Oak with two women and a man standing to the left of it and a man with a walking stick standing to the right of the tree.

Samuel G. Goodrich, The First Book of History. For Children and Youth. By the author of Peter Parley's Tales. With sixty engravings and sixteen maps. $16^{\text {th }}$ edition. (Boston: Charles J. Hendee, 1836), 25. "Charter Oak in Hartford" with a couple standing to the right of it.

Samuel G. Goodrich, A Pictorial History of the Western World. A Pictorial History of America, Embracing both the Northern and Southern Portions of the New World. Illustrated with more than Three Hundred Engravings (Hartford: House and Brown, 1848), 443. "Wadsworth concealing the charter of Connecticut in the oak." Shows an eighteenth century gentleman with the charter in hand next to the trunk of the tree, looking back over his shoulder towards the Connecticut Assembly House.

Samuel G. Goodrich, Parley's First Book of History. The First Book of History, for Children and Youth. With sixty-eight engravings and sixteen maps. $4^{\text {th }}$ edition (Boston: Jenks, Palmer and Co., 1849), 39. "Charter Oak in Hartford" with a man and two women standing to the right of it.

Benson J. Lossing, Pictorial History of the United States for Schools and Families (New York: Mason Brothers, 1858), 125. "The Charter Oak" with Wadsworth standing to the left of it.

Benson J. Lossing, A Primary History of the United States. For Schools and Families (New York: Mason Brothers, 1867), 82. "The Charter Oak" with the same image as is included in the 1858 Pictorial History of the United States.

Benson J. Lossing, A Centennial Edition of the History of the United States: From the Discovery of America to the End of the First One Hundred Years of American Independence (Hartford: Thomas Belknap, 1876), 156. "The Charter Oak" with same image as 1858 and 1867 editions. 
Scene fourteen: Boston tea party.

Nathaniel Currier lithographer, The Destruction of Tea at Boston Harbor, 1846, hand-colored lithograph. Historiscope scene close but not exact copy.

Samuel G. Goodrich, History of All Nations, From the Earliest Periods to the Present Time; or Universal History: in which the History of Every Nation, Ancient or Modern, is Separately Given. Illustrated by 70 Stylographic Maps, and 700 Engravings (New York and Auburn: Miller, Orton and Mulligan, 1856), 1122.

Jacob K. Neff, Thrilling Incidents in American History: Comprising the Most Striking and Remarkable Events of the Revolution, the French War, the Tripolitan War, the Indian Wars, the Second War with Great Britain, and the Mexican War (Philadelphia: John E. Potter and Co., 1866), 35.

Scene fifteen: Battle of Lexington.

Felix Octavius Carr Darley (1822-1888) artist, 'First Blow for Liberty.' To the Memory of the Patriots of 1775, 1858, illustration.

Alexander Hay Ritchie (1822-1895) engraver, First Blow for Liberty, 1863, engraving, Library of Congress Photo, Print, Drawing.

L.J. Campbell, A Concise School History of the United States based on Seavey's Goodrich's History (New York: Tainto Brothers, Merrill and Co., 1870), 74.

Historiscope scene is similar but adds women.

Scene sixteen: Battle of Bunker Hill.

John Trumbull (1756-1843), The Death of General Warren at the Battle of Bunker Hill, June 17, 1775, 1813-1831, oil on canvas.

Alfred M. Hoffy lithographer, The Battle of Bunker's Hill, June 17, 1775, 1840, black and gold lithograph., Library of Congress Photo, Print, Drawing.

Kelloggs and Thayer (New York, Hartford and Buffalo) lithographers, Battle at Bunker's Hill (Near Boston), 1846-1847, hand-colored lithograph, Connecticut Historical Society Collections.

E.C. Kellogg (New York and Hartford) and H. Thayer (Buffalo) lithographers, Battle at Bunker's Hill (Near Boston), 1852-1854, hand-colored lithograph, Connecticut Historical Society Collections.

George Edward Perine (1837-1885) engraver, P.S. Duval \& Co. Publisher, The Battle at Bunker's Hill, 1862, engraving, New York Public Library Digital Collections.

Samuel G. Goodrich, The Tales of Peter Parley About America (Boston: Carter, Hendee, and Co., 1828), 115.

Samuel G. Goodrich, The First Book of History. For Children and Youth. With sixty engravings and sixteen maps. $16^{\text {th }}$ edition (Boston: Charles J. Hendee, 1836), 112.

Samuel G. Goodrich, Parley's First Book of History. The First Book of History, for Children and Youth. With sixty-eight engravings and sixteen maps. $4^{\text {th }}$ edition (Boston: Jenks, Palmer and Co., 1849), 149.

Samuel G. Goodrich, A Pictorial History of the United States. With Notices of Other Portions of America (Philadelphia: E.H. Butler and Co., 1857), 158.

Charles A. Goodrich, History of the United States of America; for Use of Schools (New York: Taintor Brothers, 1867), 116. 
Samuel G. Goodrich, A Pictorial History of the United States. With Notices of Other Portions of America (Philadelphia: E.H. Butler and Co., 1872), 191.

Scene seventeen: Bunker Hill Monument

Samuel G. Goodrich, Parley's First Book of History. The First Book of History, for Children and Youth. With sixty-eight engravings and sixteen maps. $4^{\text {th }}$ edition (Boston: Jenks, Palmer and Co., 1849), 31.

M. Lafever, artist; Karl Gildermeister (1820-1869), lithographer; Nagel and Weingaertner, printers. Order of United Americans certificate (a nativist fraternal organization), 1850, lithograph on woven paper, Library of Congress Photo, Print, Drawing.

Benson J. Lossing, Pictorial History of the United States for Schools and Families (New York: Mason Brothers, 1858), 191.

Benson J. Lossing, A Primary History of the United States. For Schools and Families (New York: Mason Brothers, 1867), 121.

Benson J. Lossing, A Common-School History of the United States; From the Earliest Period to the Present Time (New York: Sheldon and Company, 1870), 133.

Benson J. Lossing, A Centennial Edition of the History of the United States: From the Discovery of America to the End of the First One Hundred Years of American Independence (Hartford: Thomas Belknap, 1876), 235.

Scene eighteen: General George Washington as Commander-in-Chief. John Faed, artist (1820-1902), Portrait of George Washington Taking the Salute at Trenton, n.d., oil on canvas.

William Holl, engraver (1807-1871) Washington Receiving a Salute on the Field of Trenton, c. 1860, engraving, Library of Congress Photo, Print, Drawing.

Scene nineteen: Assault on Quebec by the American Army. Jacob K. Neff, Thrilling Incidents in American History: Comprising the Most Striking and Remarkable Events of the Revolution, the French War, the Tripolitan War, the Indian Wars, the Second War with Great Britain, and the Mexican War (Philadelphia: John E. Potter and Co., 1866), 150.

Scene twenty: British Attack on Fort Moultrie.

Jacob K. Neff, Thrilling Incidents in American History: Comprising the Most Striking and Remarkable Events of the Revolution, the French War, the Tripolitan War, the Indian Wars, the Second War with Great Britain, and the Mexican War (Philadelphia: John E. Potter and Co., 1866), 164.

Samuel G. Goodrich, A Pictorial History of the Western World, A Pictorial History of America, Embracing Both the Northern and Southern Portions of the New World, (Hartford: House and Brown, 1848), 562. Historiscope scene very similar but not an exact copy. 
Scene twenty-one: Independence Hall

Benson J. Lossing, Pictorial History of the United States for Schools and Families (New York: Mason Brothers, 1858), 202.

Benson J. Lossing, The Pictorial Field-book of the Revolution, or, Illustrations, by Pen and Pencil, of the History, Biography, Scenery, Relics, and Traditions of the War for Independence, Vol. II In Two Volumes. (New York: Harper and Brothers, 1860), 66.

Jacob K. Neff, Thrilling Incidents in American History: Comprising the Most Striking and Remarkable Events of the Revolution, the French War, the Tripolitan War, the Indian Wars, the Second War with Great Britain, and the Mexican War (Philadelphia: John E. Potter and Co., 1866), 172.

Benson J. Lossing, A Primary History of the United States. For Schools and Families (New York: Mason Brothers, 1867), 129.

Benson J. Lossing, A Common-School History of the United States; From the Earliest Period to the Present Time (New York: Sheldon and Company, 1870), 142.

Benson J. Lossing, A Centennial Edition of the History of the United States: From the Discovery of America to the End of the First One Hundred Years of American Independence (Hartford: Thomas Belknap, 1876), 250.

Charles A. Goodrich. The Child's History of the United States, Revised by A.B. Beard (Philadelphia: Cowperthwait and Co., 1878), 70.

Scene twenty-two: Winter at Valley Forge.

Nathaniel Currier, Washington at Valley Forge - December 1777, 1848-1856, hand-colored lithograph, Metropolitan Museum Collections.

Samuel G. Goodrich, A Pictorial History of the Western World, A Pictorial History of America, Embracing Both the Northern and Southern Portions of the New World, (Hartford: House and Brown, 1848), 586. Historiscope scene similar but not exact copy.

Tompkins Harrison Matteson (1813-1884), George Washington at Valley Forge, 1854, oil on canvas. Historiscope scene similar but not exact copy.

Samuel G. Goodrich, The American Child's Pictorial History of the United States, Illustrated by sixty engravings (Philadelphia: E.H. Butler and Co., 1865 and 1868), 153. Historiscope scene similar but not exact copy.

Scene twenty-three: Putnam at Horseneck.

E.B. and E.C. Kellogg, General Israel Putnam, The Iron Son of '76' effecting his escape from the British Dragoons, 1846-1847, hand-colored lithograph, Connecticut Historical Society Collections.

Samuel G. Goodrich, A Pictorial History of the Western World, A Pictorial History of America, Embracing Both the Northern and Southern Portions of the New World, (Hartford: House and Brown, 1848), 621. Historiscope scene very similar but not an exact copy.

Charles A. Goodrich History of the United States of America; For Use of Schools (New York: Taintor Brothers Merrill and Co., 1867), 135. 
Scene twenty-four: Arrest of Major André.

Asher Brown Durand (1796-1886), The Capture of Major André, 1835, oil on canvas.

Figures engraved by Alfred Jones (1819-1900), landscape engraved by James Smillie (1807-1885), The Capture of Major André, 1846, engraving, Library of Congress Photo, Print, Drawing.

Charles A. Goodrich History of the United States of America; For Use of Schools (New York: Taintor Brothers Merrill and Co., 1867), 135.

Scene twenty-five: Lord Cornwallis Surrendering to Washington.

Nathaniel Currier, Surrender of Lord Cornwallis at York-town, Va., October 1781, 1845, hand-colored lithograph, Springfield Museums collections.

Robert Smirke (1752-1845) artist and James Heath (1757-1834) engraver, Cornwallis resigning his sword to Washington, n.d., engraving, New York Public Library Digital Collections.

Robert Smirke (1752-1845) artist and Archer \& Boilly engraver, Cornwallis resigning his sword to Washington, 1854, steel engraving, New York Public Library Digital Collections.

Robert Smirke (1752-1845) artist, Robert Fulton (1765-1815) artist and Max Rosenthal (1833-1918) lithographer, Cornwallis resigning his sword to Washington, 1856, five color lithograph, New York Public Library Digital Collections.

Samuel G. Goodrich, The Tales of Peter Parley About America, second edition (Boston: Carter and Hendee, 1828), 137.

Samuel G. Goodrich, The Tales of Peter Parley About America, third edition (Boston: Carter and Hendee, 1830), 137.

Samuel G. Goodrich, The Tales of Peter Parley About America, revised edition (Philadelphia: Thomas, Cowperthwait and Co., 1845), 117. 
Figure 1.1. “Check-Mate!” Harper's Weekly IX, no. 440 (June 3, 1865): 337. Wood engraving. Reproduced digitally by Illustrated Civil War Newspapers and Magazines.

staging-lincolnandthecivilwar-com.proxy.mul.missouri.edu/BrowseTitle.asp 


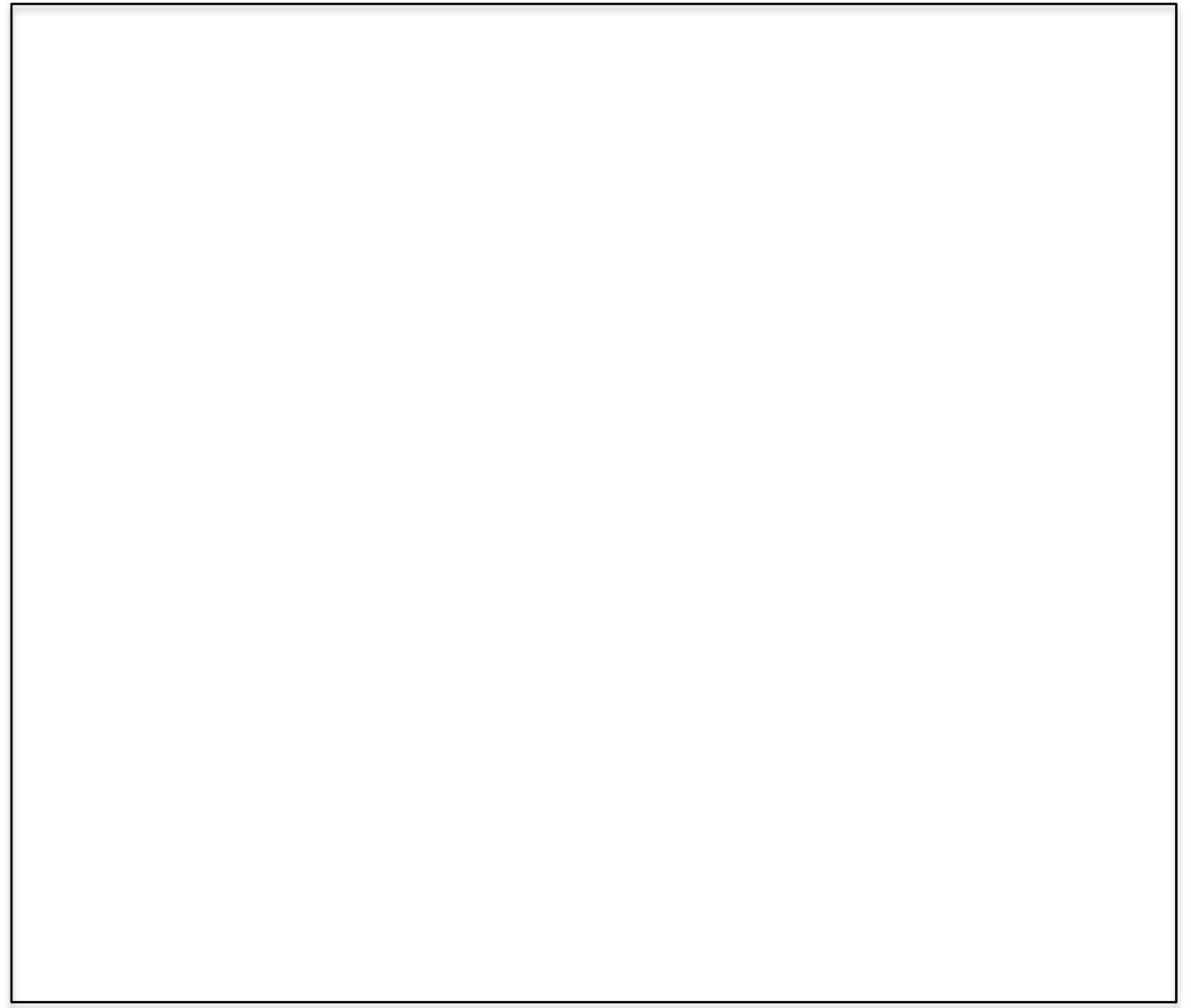

Figure 1.2. Milton Bradley \& Company, The Checkered Game of Life, 1860. Pasteboard, paper and chromolithography. Reproduced digitally by the American Antiquarian Society.

gigi.mwa.org/netpub/server.np?quickfind=519281\&sorton=filename\&catalog=catal og\&site=public\&template $=$ results.np 


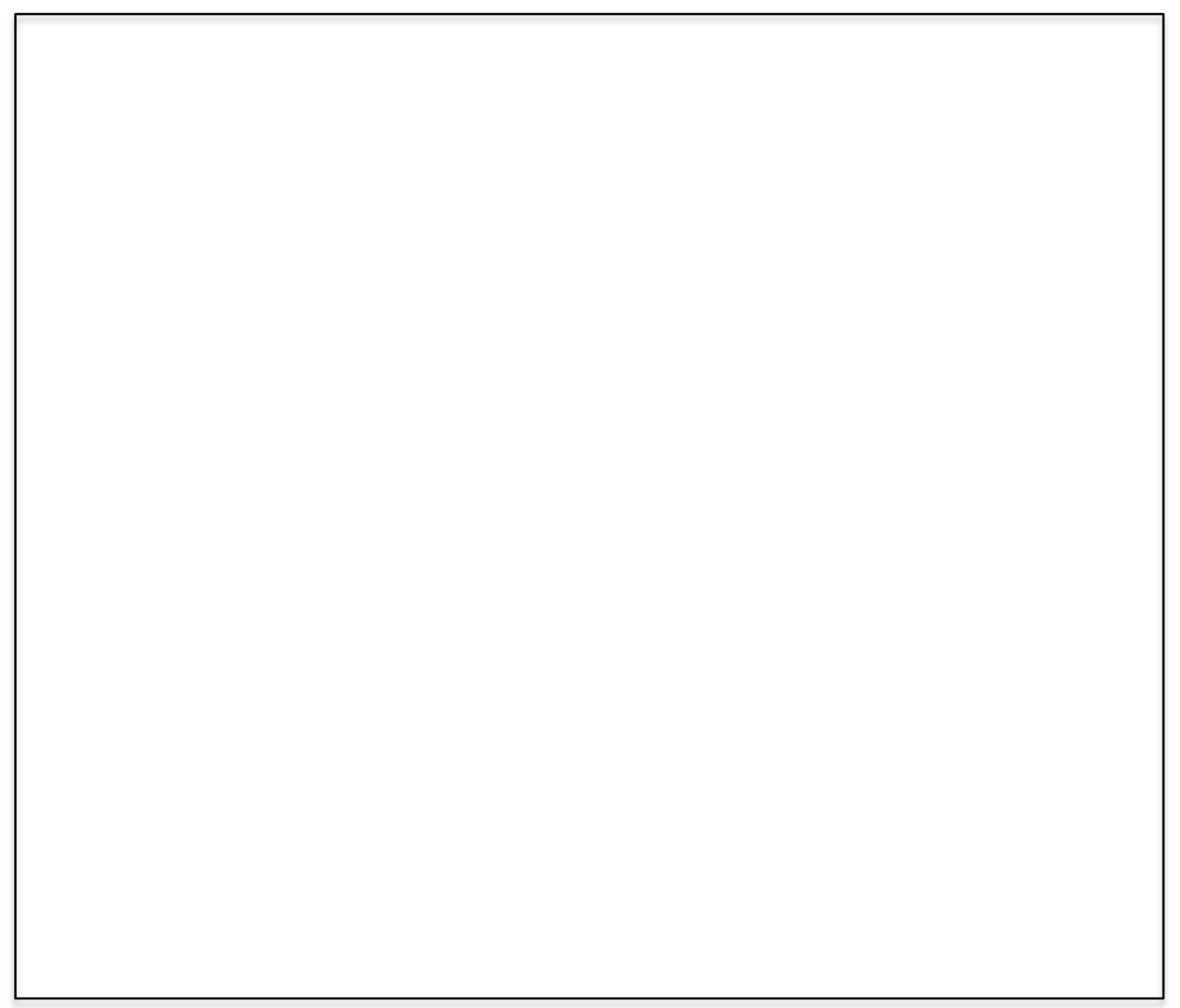

Figure 1.3. Milton Bradley \& Company, The Myriopticon, A Historical Panorama of the Rebellion, 1866. Pasteboard, paper and chromolithography. Reproduced digitally by Beinecke Rare Book and Manuscript Library, Yale University, and sent per request of the author. 


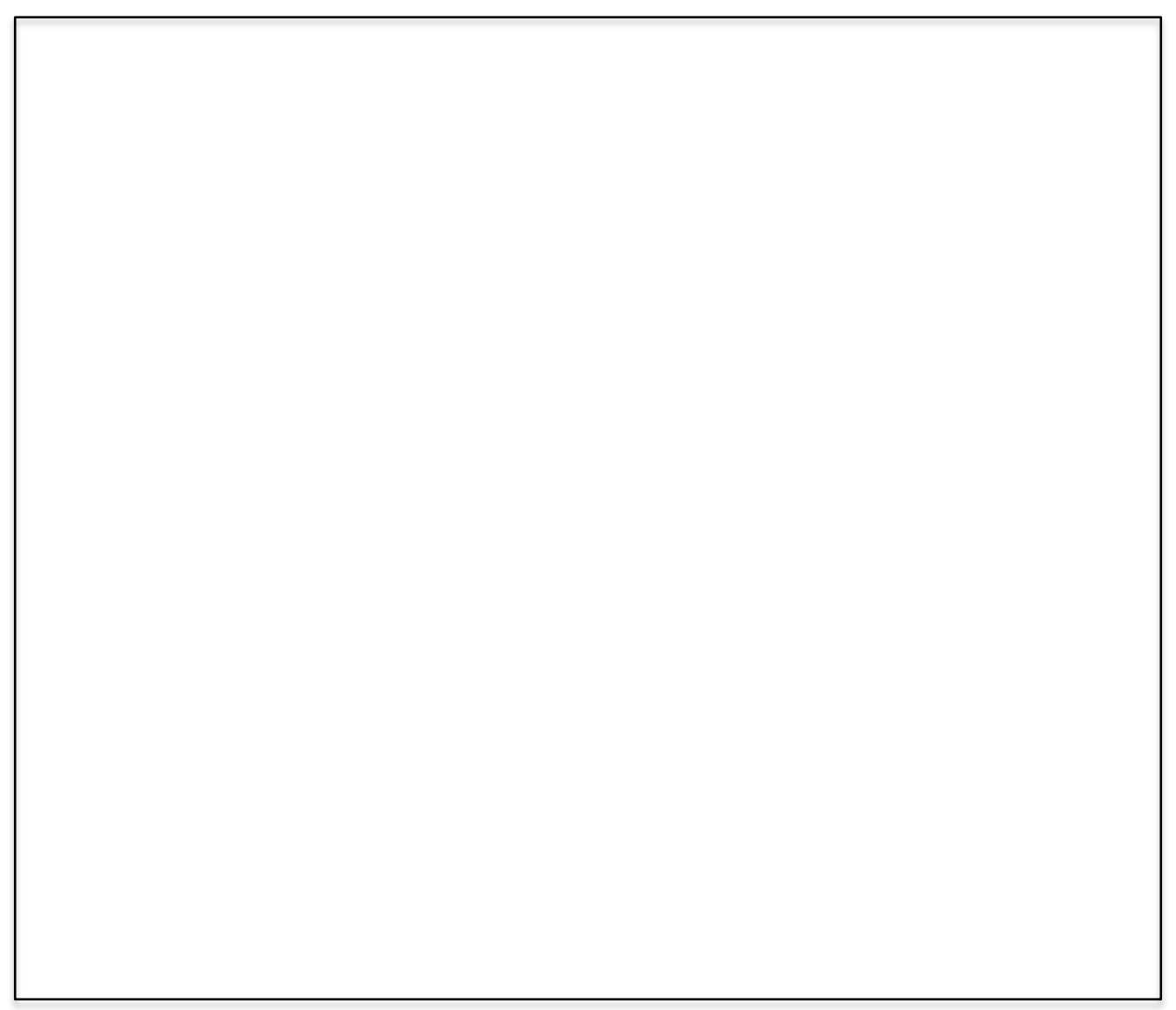

Figure 1.4. Milton Bradley \& Company, The Historiscope, A Panorama \& History of America, 1868. Pasteboard, paper and chromolithography. Reproduced digitally by Beinecke Rare Book and Manuscript Library, Yale University, and sent per request of the author. 
Figure 2.1. The Card House, Godey's Lady's Book and Magazine LXXX, no. 20 (April 1870): 323. Wood engraving. Reproduced digitally in HathiTrust babel.hathitrust.org/cgi/pt?id=pst.000020202316\&view=1up\&seq=313 


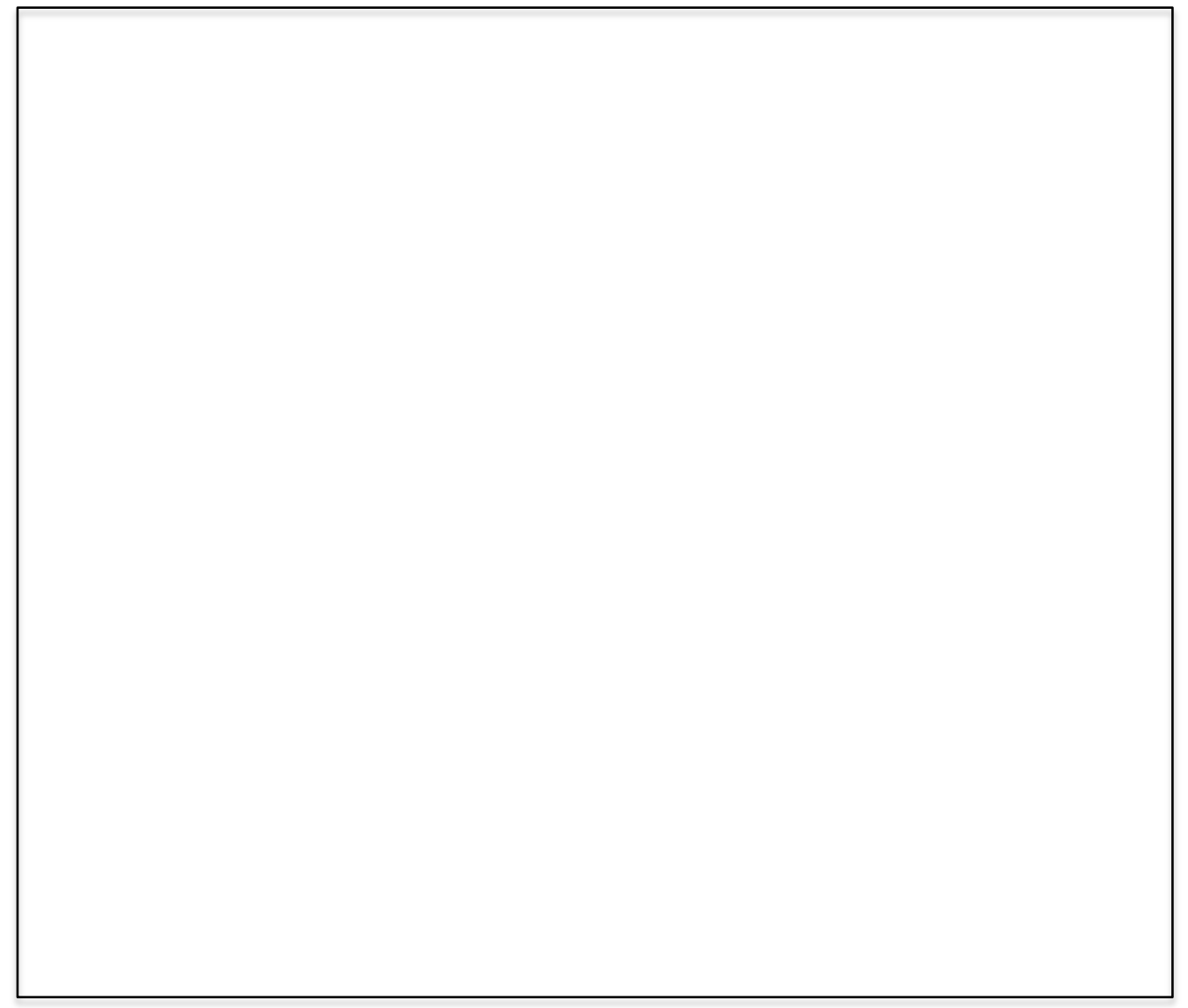

Figure 2.2. Milton Bradley \& Company, The box for The Checkered Game of Life, 1860. Pasteboard and chromolithography. Reproduced digitally by the American Antiquarian Society. gigi.mwa.org/netpub/server.np?quickfind=519281\&sorton=filename\&catalog=catal og\&site=public\&template=results.np 


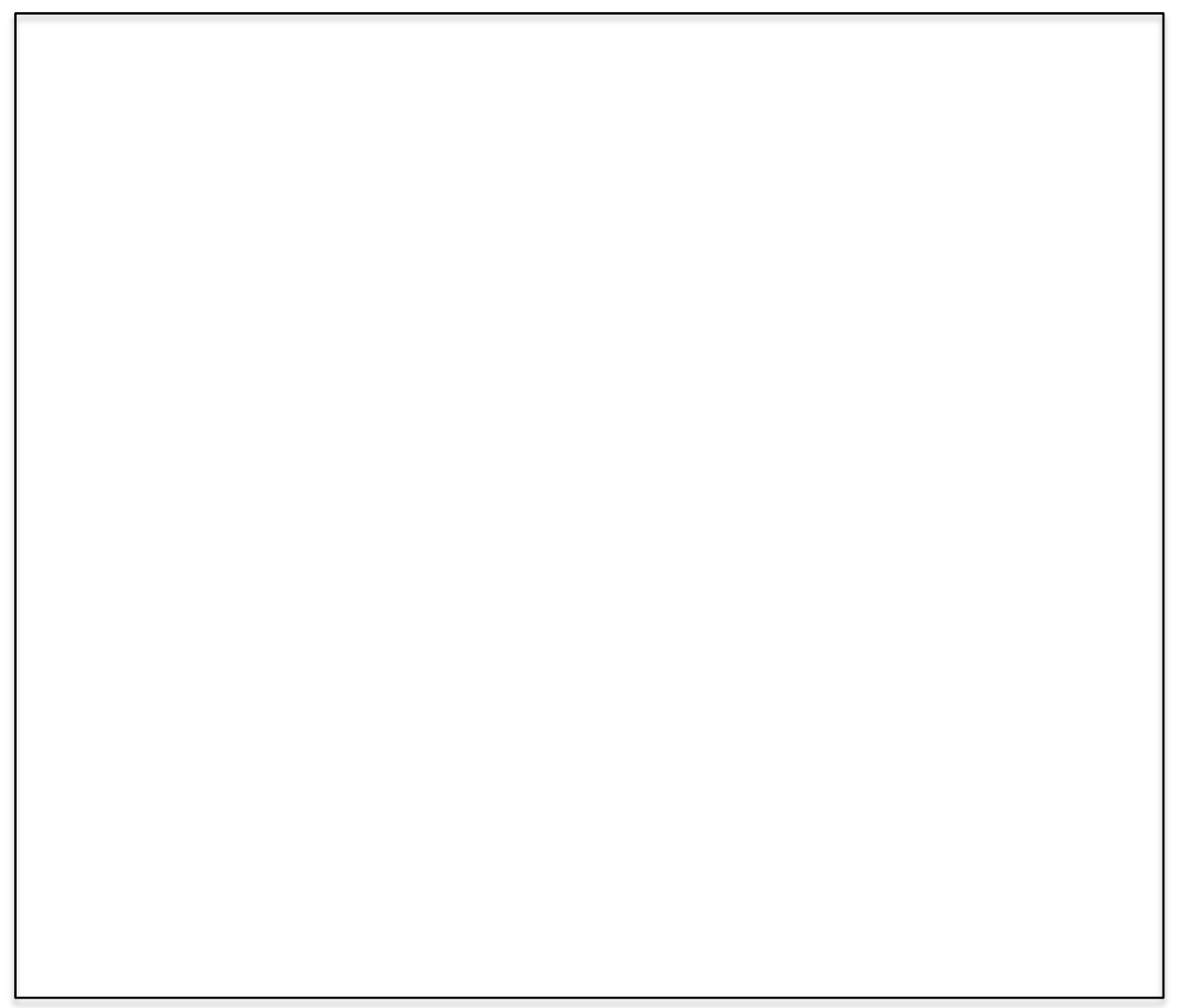

Figure 2.3. Charles R. Parsons and Lyman W. Atwater, The Four Seasons of Life: Old Age - The Season of Rest, 1868. Currier \& Ives lithograph. Reproduced digitally by Wikimedia Commons

commons.wikimedia.org/wiki/File:Currier_and_Ives_-_The_Four_Seasons_of_Life__Old_Age.png 


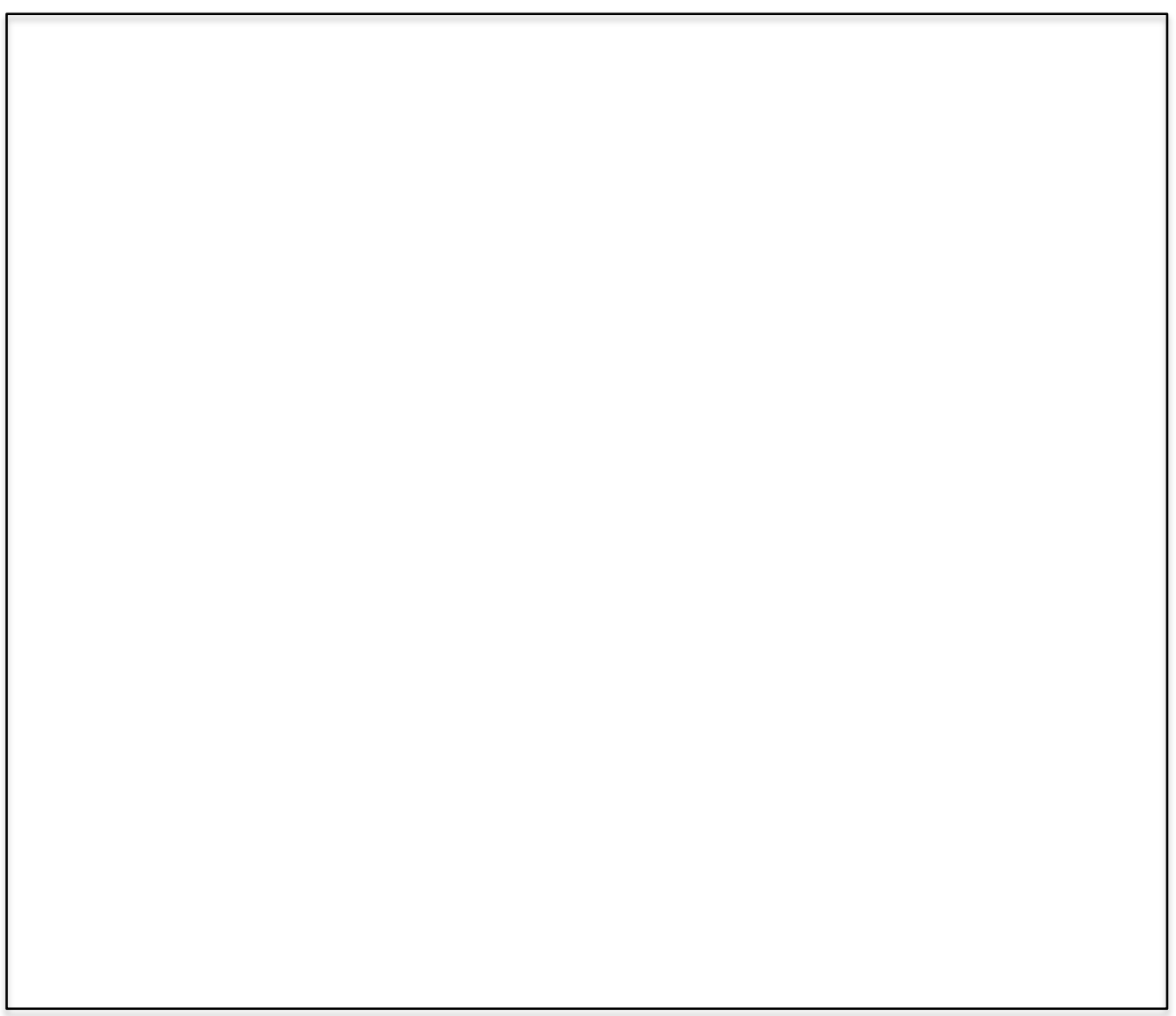

Figure 2.4. Milton Bradley \& Company, the teetotum for The Checkered Game of Life, 1860. Pasteboard and chromolithography. Reproduced digitally by Thebiggamehunter.com/games-one-by-one/checkered-game-of-life/ 
Figure 2.5. Milton Bradley \& Company, the record dial for The Checkered Game of Life, 1860. Pasteboard, paper and chromolithography. Reproduced digitally by Thebiggamehunter.com/games-one-by-one/checkered-game-of-life/ 


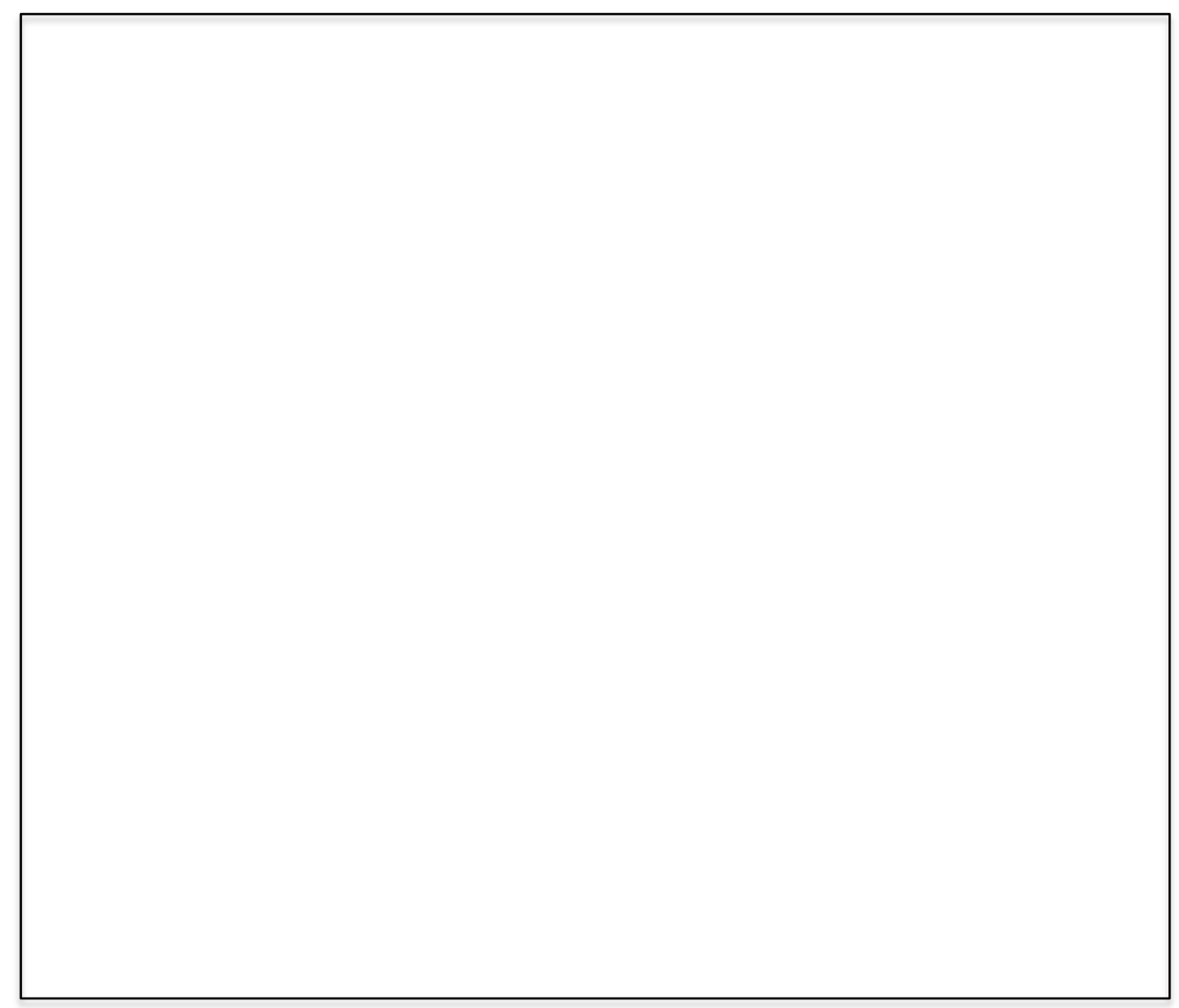

Figure 2.6. W. and S.B. Ives Company, The Mansion of Happiness, 1843. Pasteboard, paper and chromolithography. Reproduced digitally by the American Antiquarian Society.

gigi.mwa.org/netpub/server.np?quickfind=519298\&sorton=filename\&catalog=catal og\&site=public\&template=results.np 


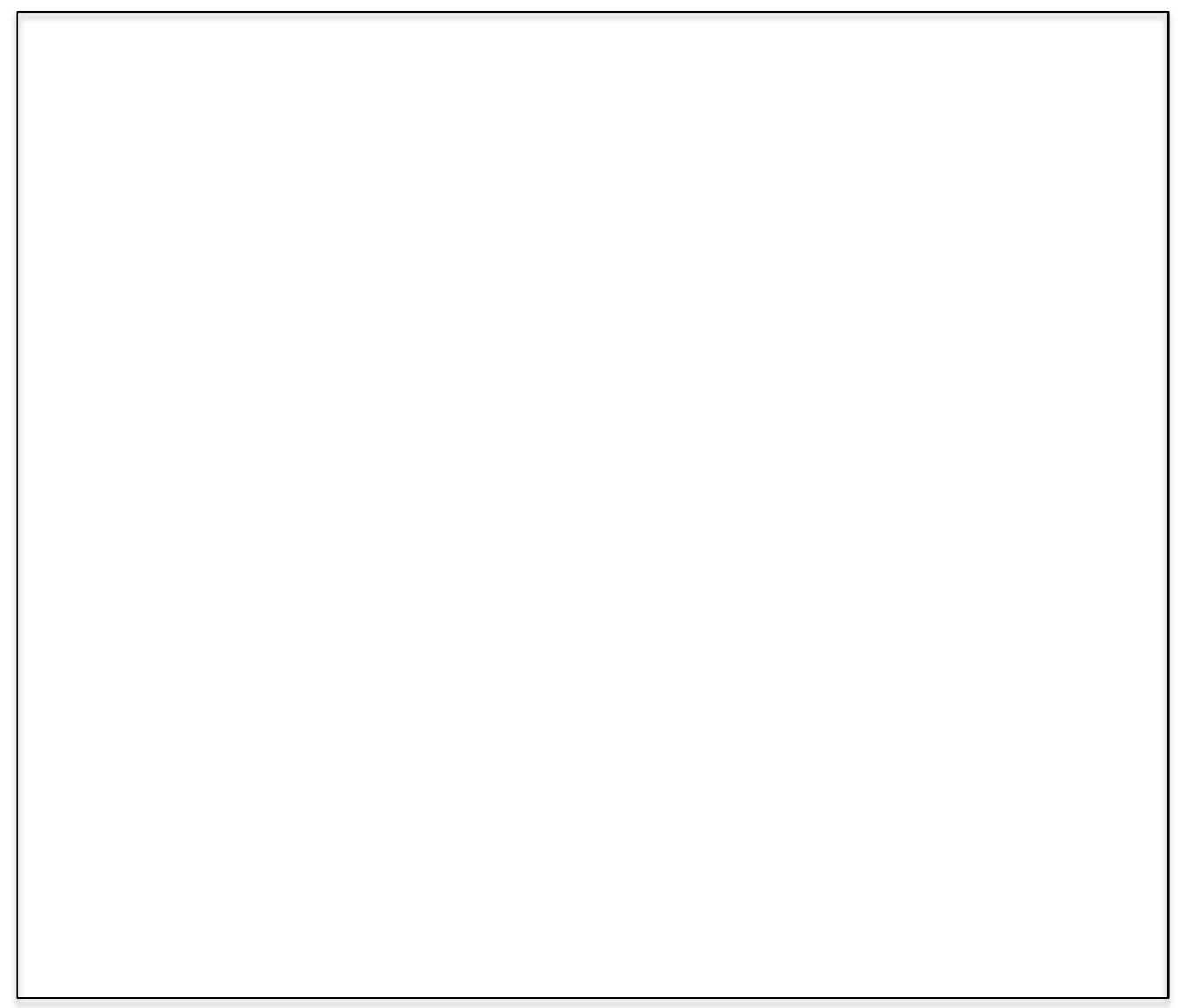

Figure 2.7. Albert Alden, The Life and Age of Man: Stages of Man's Life from the Cradle to the Grave, wherein all Christians may behold their frail nature and the miseries that attend a sinful life, 1835. Broadside, engraving. Reproduced digitally by Geographicus. geographicus.com/P/AntiqueMap/AgeofMan-albertalden-1835 


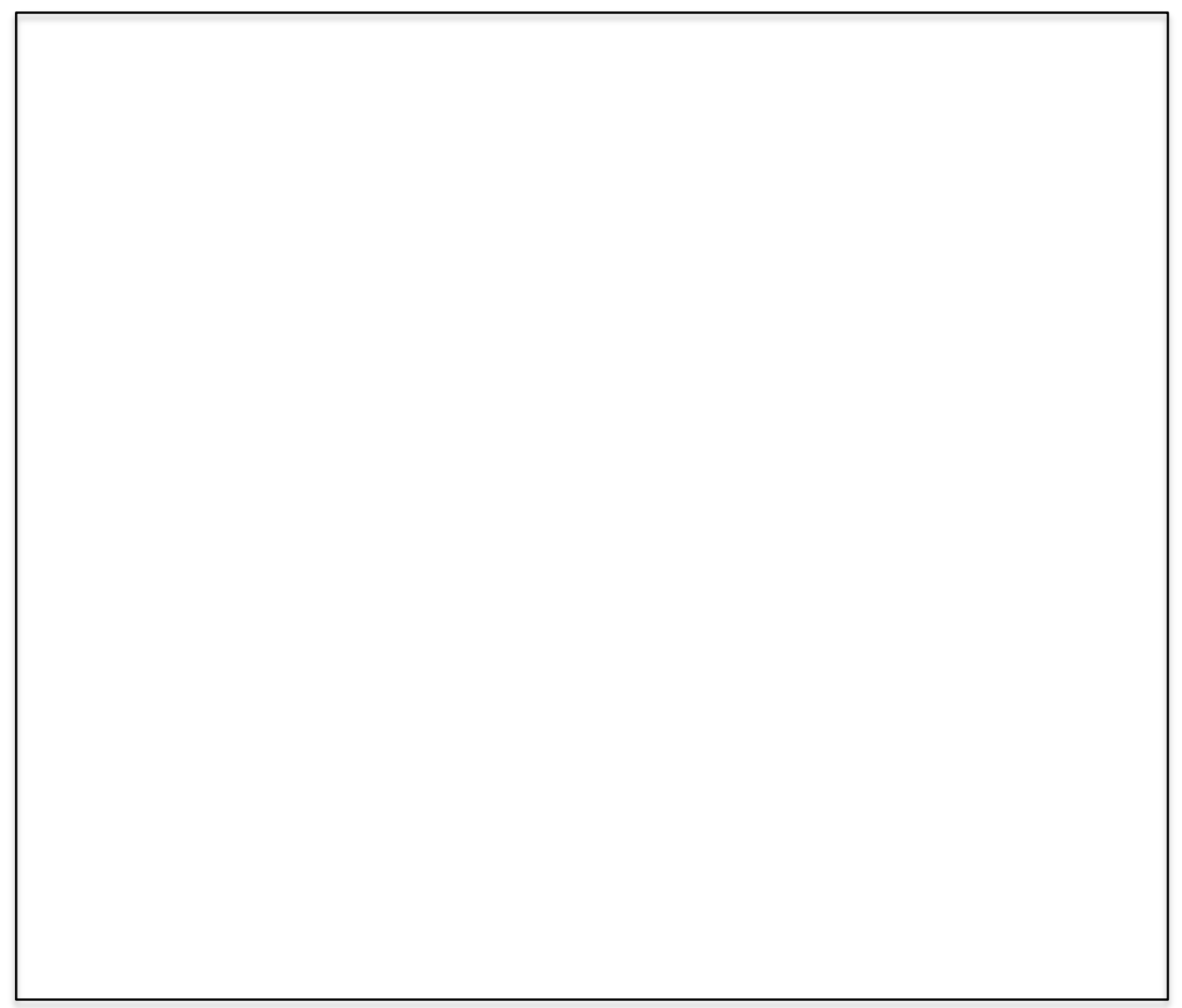

Figure 2.8. Nathaniel Currier, The Drunkard's Progress: From First Glass to Grave, c. 1848. Hand colored lithograph. Reproduced digitally by Wikimedia Commons. commons.wikimedia.org/wiki/File:The_Drunkard\%27s_Progress_-_Color.jpg 


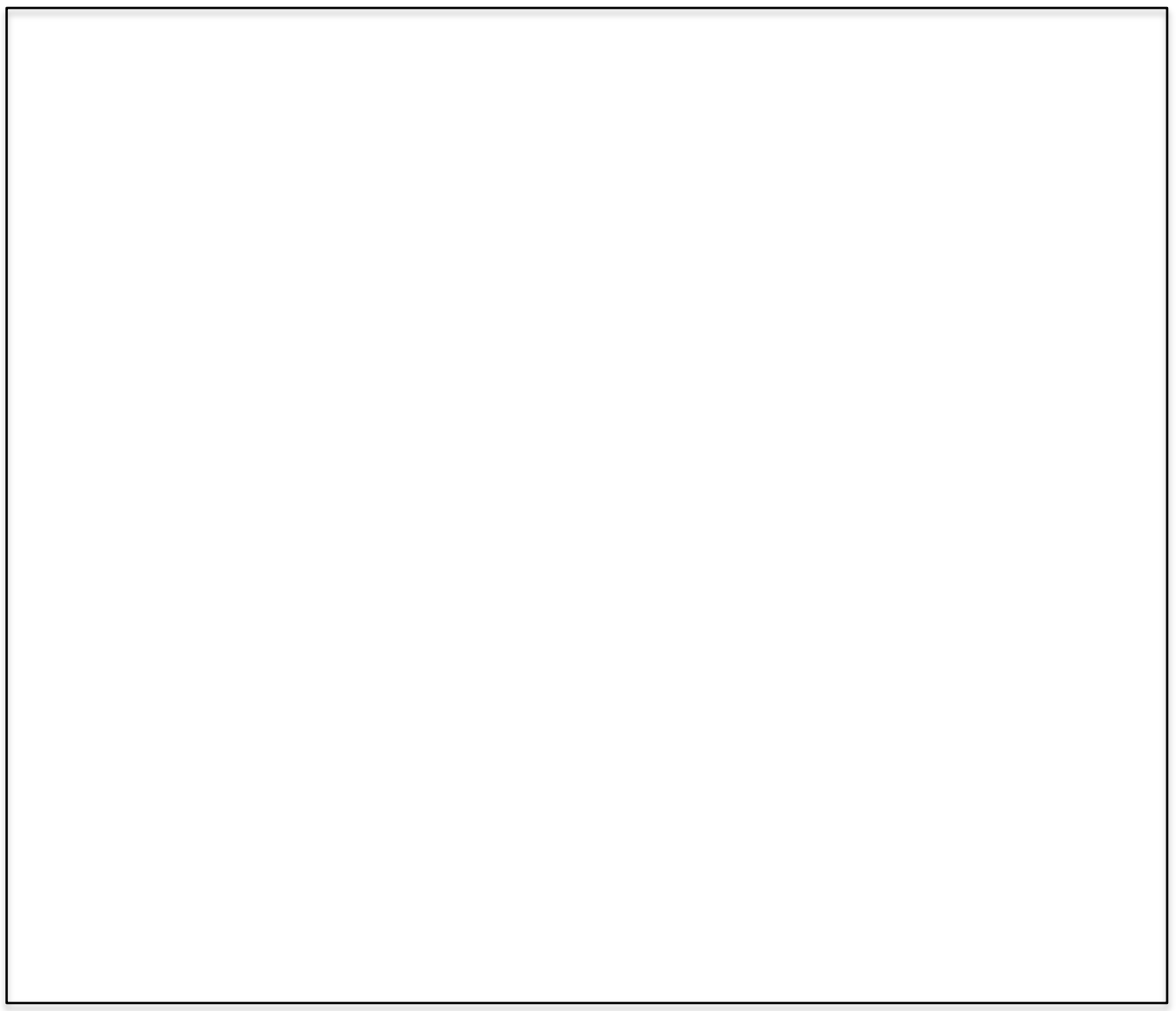

Figure 2.9. Currier \& Ives, The Tree of Temperance, 1872. Hand colored lithograph. Reproduced digitally by the American Antiquarian Society.

gigi.mwa.org/netpub/server.np?quickfind=149277\&sorton=filename\&catalog=catal og\&site=public\&template=results.np 


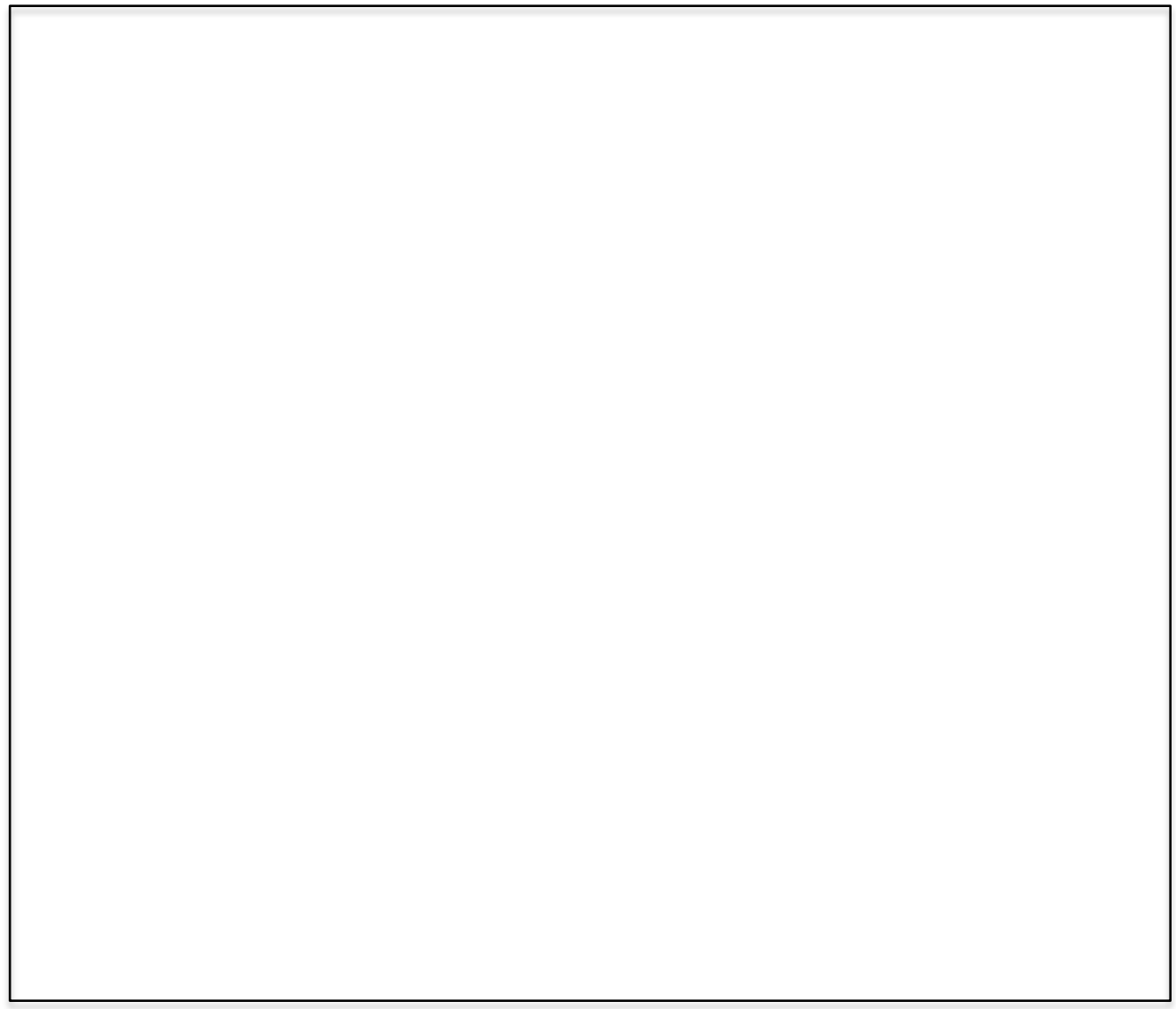

Figure 3.1. Scene one in the Myriopticon, Major Anderson and his men entering Fort Sumter. Chromolithography on paper scroll. Reproduced digitally by Beinecke Rare Book and Manuscript Library, Yale University and sent per request of the author. 


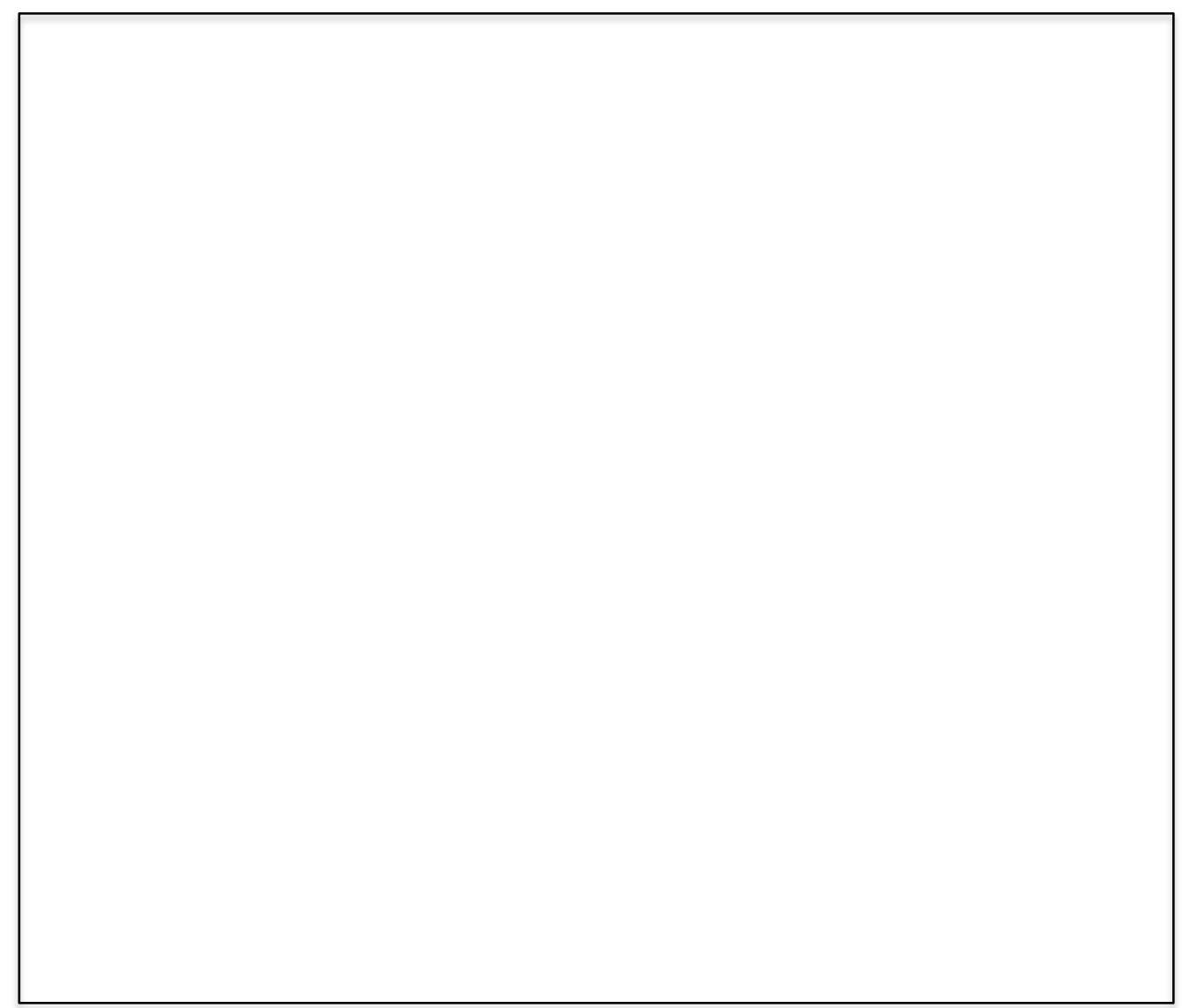

Figure 3.2. Scene two in the Myriopticon, Bombardment of Fort Sumter. Chromolithography on paper scroll. Reproduced digitally by Beinecke Rare Book and Manuscript Library, Yale University and sent per request of the author. 
Figure 3.3. Scene three in the Myriopticon, First Blood shed in the Great Rebellion. Chromolithography on paper scroll. Reproduced digitally by Beinecke Rare Book and Manuscript Library, Yale University and sent per request of the author. 


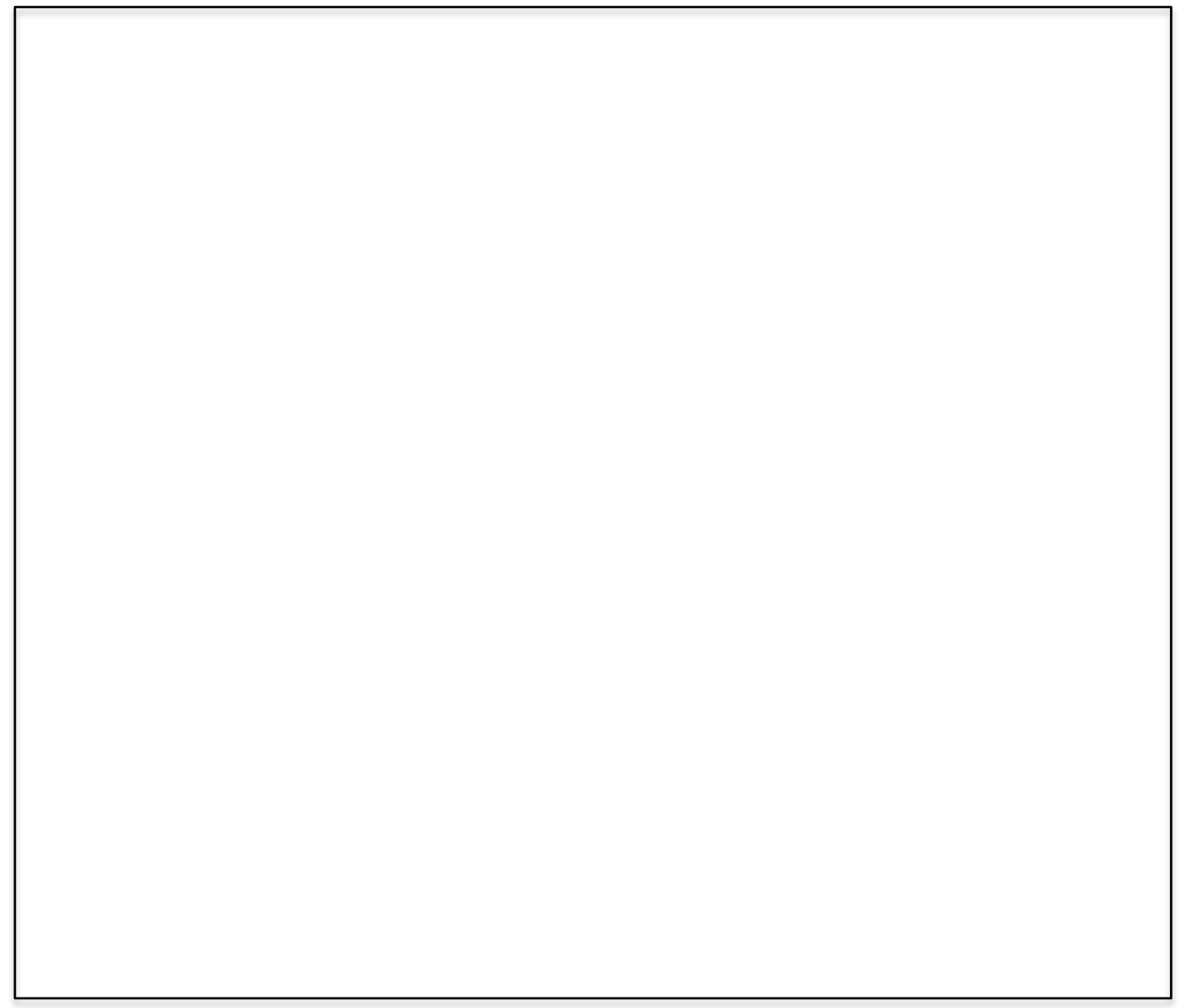

Figure 3.4. Scene four in the Myriopticon, Murder of Colonel Ellsworth. Chromolithography on paper scroll. Reproduced digitally by Beinecke Rare Book and Manuscript Library, Yale University and sent per request of the author. 


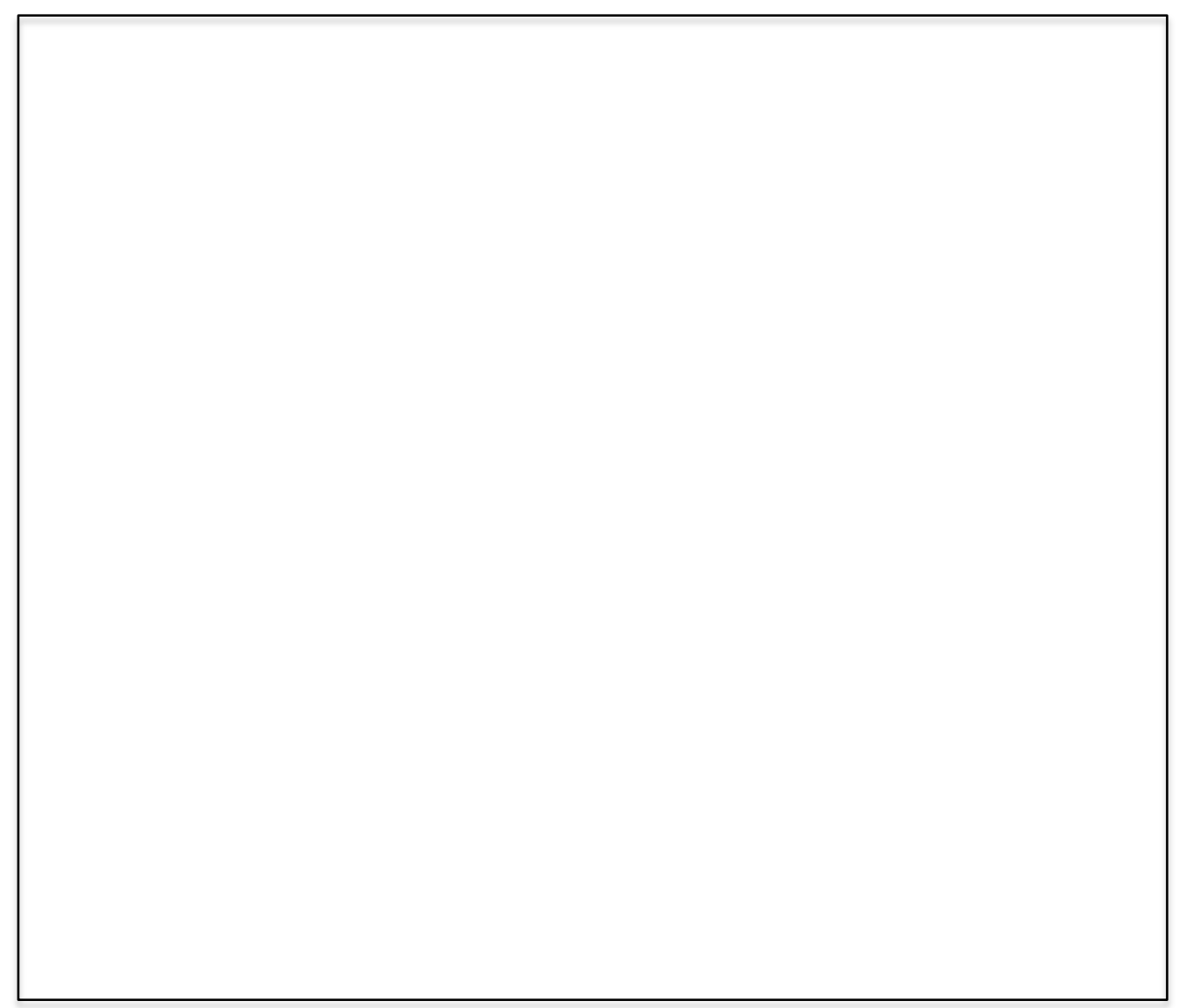

Figure 3.5. Scene sixteen in the Myriopticon, Sharpshooter. Chromolithography on paper scroll. Reproduced digitally by Beinecke Rare Book and Manuscript Library, Yale University and sent per request of the author. 


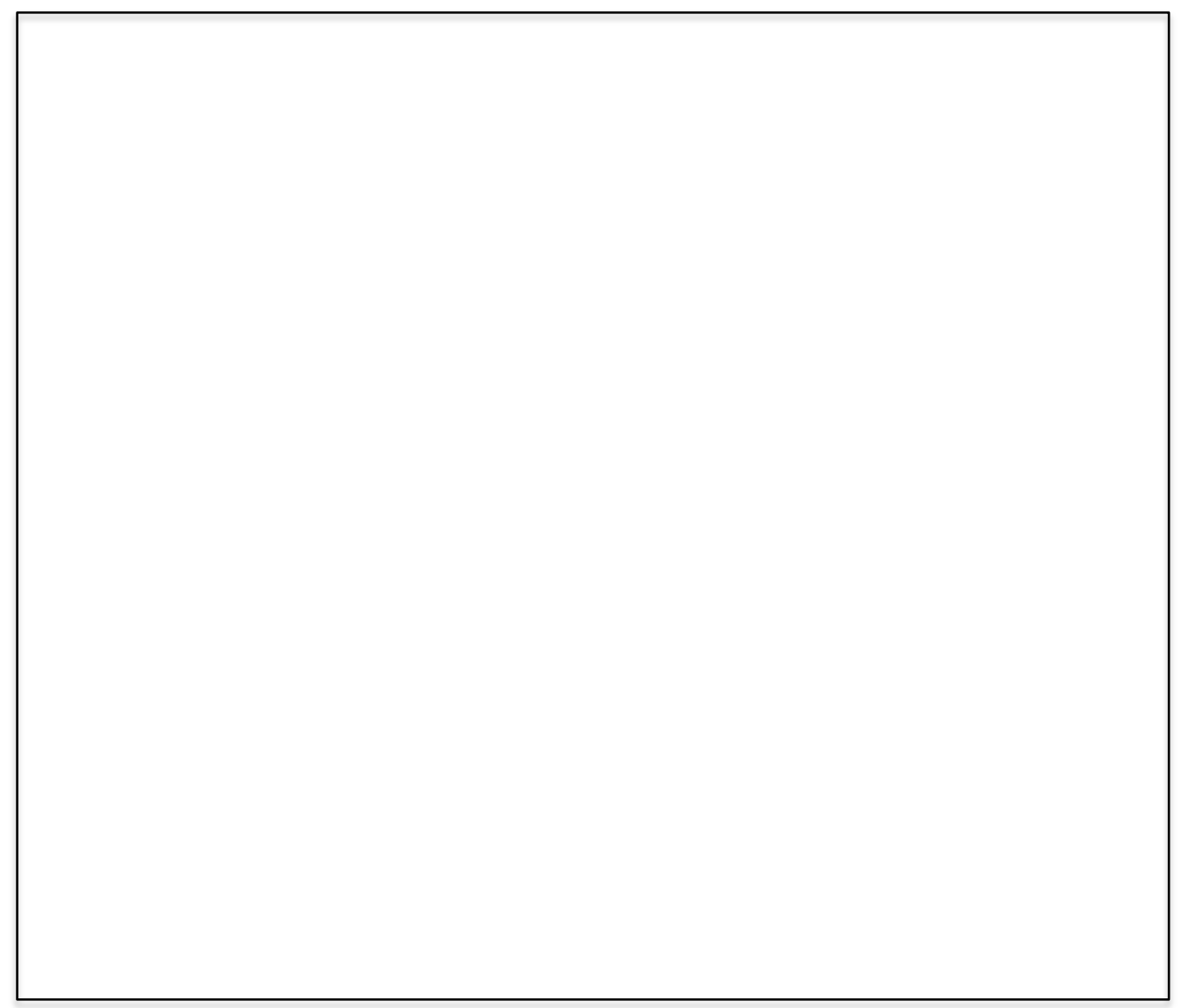

Figure 3.6. "The Army of the Potomac - A Sharpshooter on Picket Duty - (From a painting by W. Homer, Esq.)," Harper's Weekly VI, no. 307 (November 15, 1862): 724. Wood engraving. Reproduced digitally by Illustrated Civil War Newspapers and Magazines.

staging-lincolnandthecivilwar-com.proxy.mul.missouri.edu/BrowseTitle.asp 


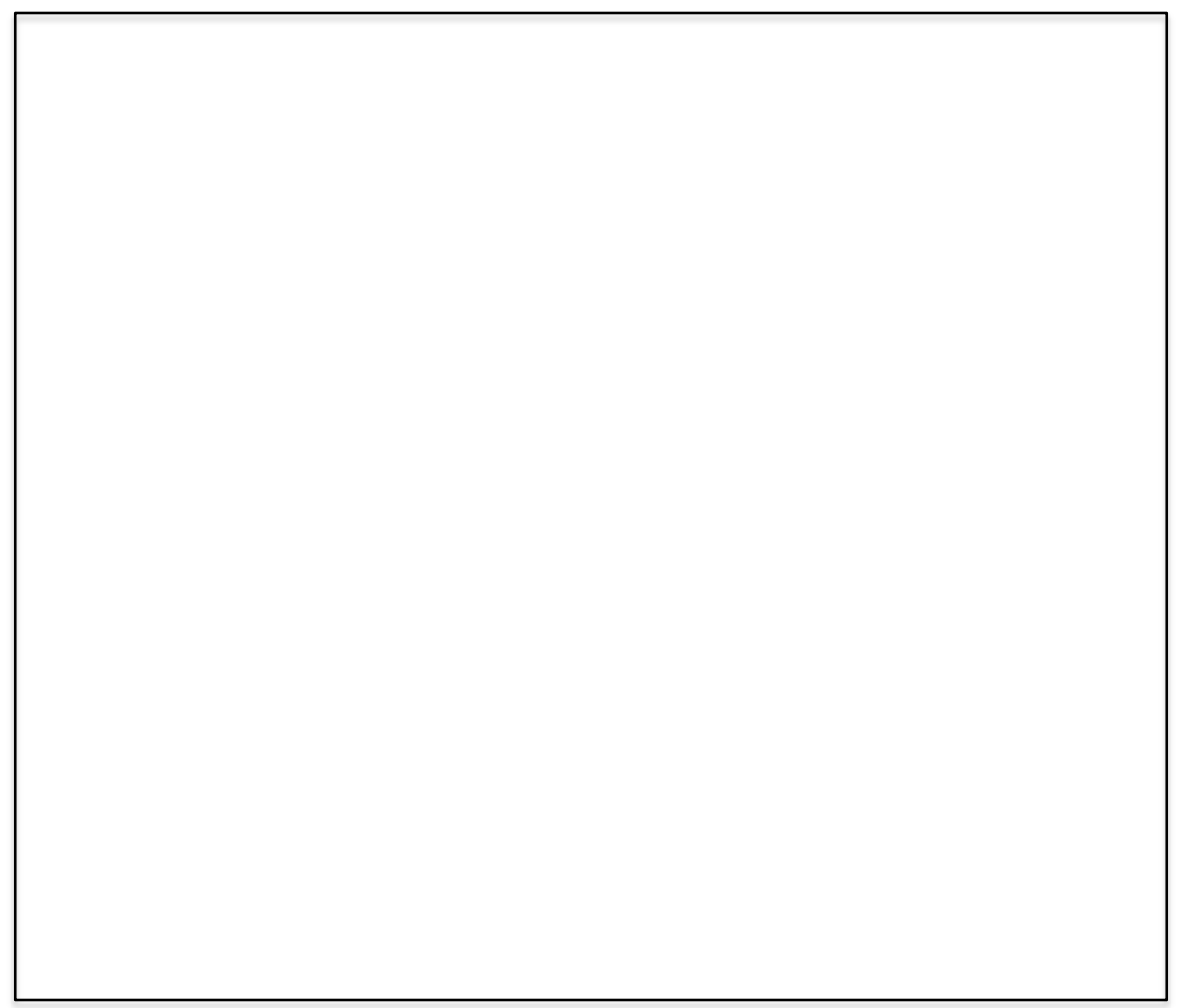

Figure 3.7. Scene ten in the Myriopticon, Encounter between the Merrimac and Monitor, $9^{\text {th }}$ of March, in Hampton Roads. Chromolithography on paper scroll. Reproduced digitally by Beinecke Rare Book and Manuscript Library, Yale University and sent per request of the author. 


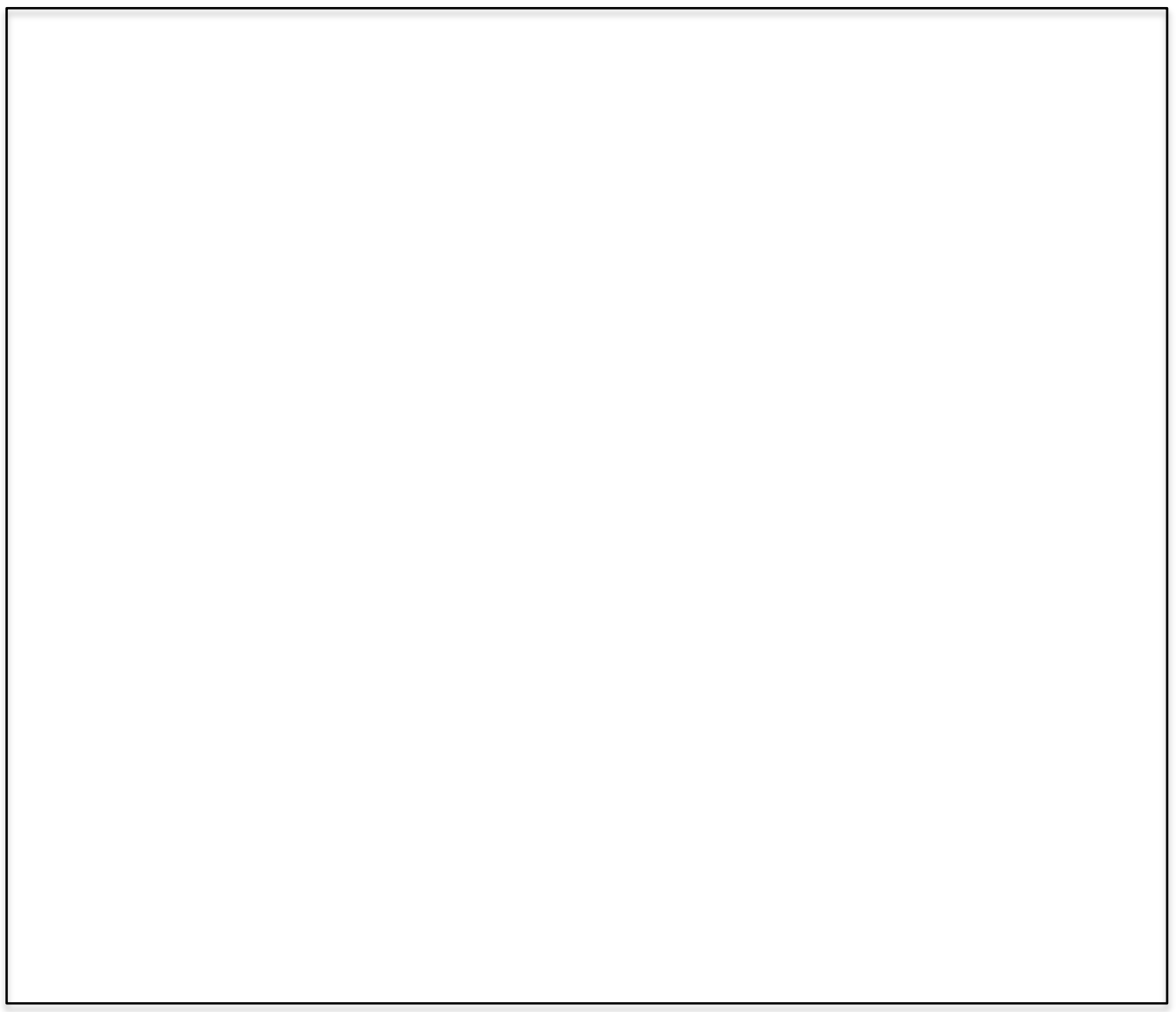

Figure 3.8. Scene fourteen in the Myriopticon, Telegraph Corps erecting telegraph wires. Chromolithography on paper scroll. Reproduced digitally by Beinecke Rare Book and Manuscript Library, Yale University and sent per request of the author. 
Figure 3.9. Scene fifteen in the Myriopticon, Wounded being cared for after the Battle of Antietam. Chromolithography on paper scroll. Reproduced digitally by Beinecke Rare Book and Manuscript Library, Yale University and sent per request of the author. 
Figure 3.10. Scene eighteen in the Myriopticon, Contrabands coming into camp. Chromolithography on paper scroll. Reproduced digitally by Beinecke Rare Book and Manuscript Library, Yale University and sent per request of the author. 
Figure 3.11. "Contrabands Coming into Camp - Drawn by Mr. A.E. Waud," Harper's Weekly VII, no.318 (January 31, 1863): 68. Wood engraving. Reproduced digitally by Illustrated Civil War Newspapers and Magazines.

staging-lincolnandthecivilwar-com.proxy.mul.missouri.edu/BrowseTitle.asp 
Figure 3.12. Scene twenty-three in the Myriopticon, Colored troops of the United States enter Charleston, February 1865. Chromolithography on paper scroll. Reproduced digitally by Beinecke Rare Book and Manuscript Library, Yale University and sent per request of the author. 


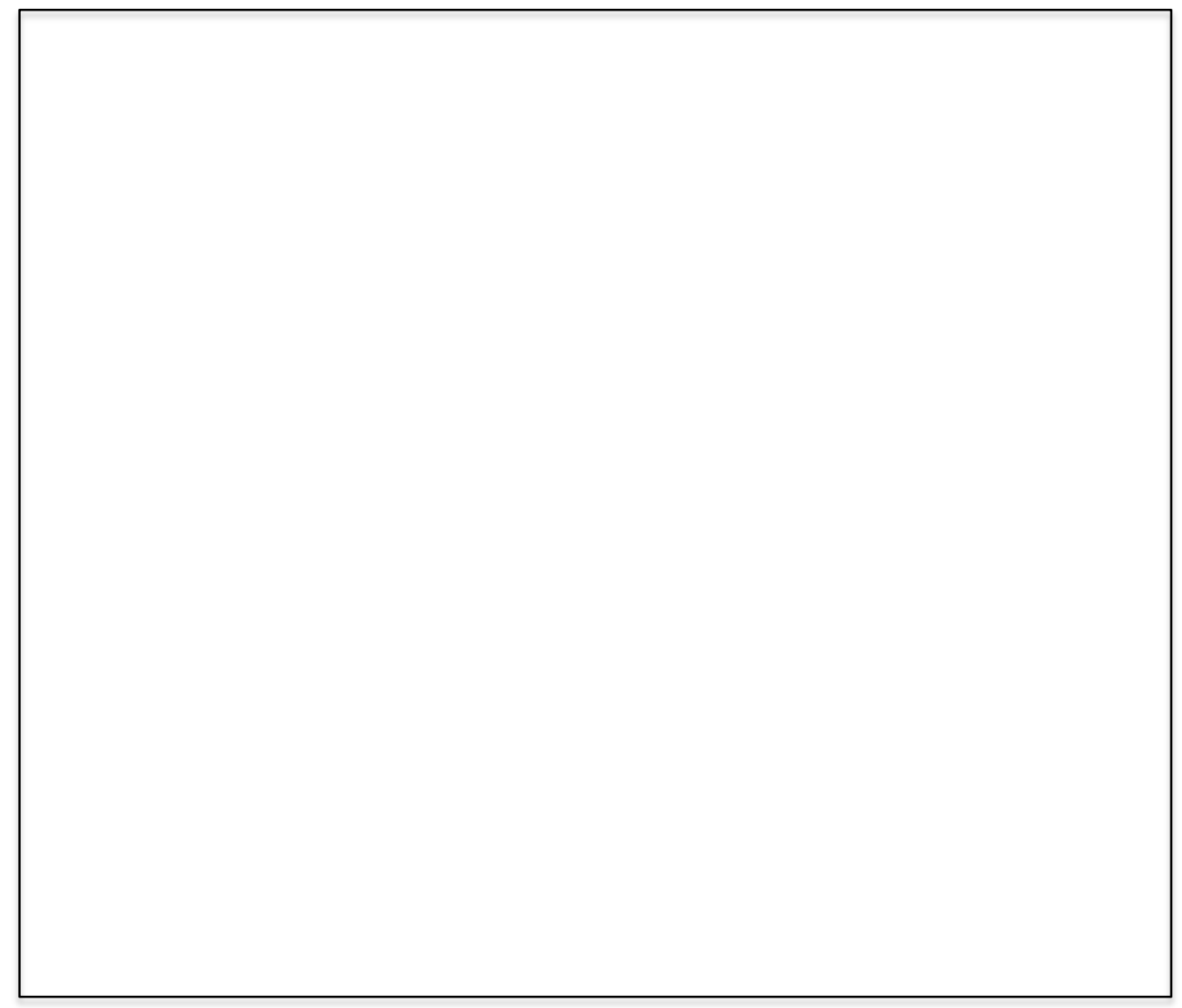

Figure 3.13. Scene nine in the Myriopticon, Fort Donelson. Chromolithography on paper scroll. Reproduced digitally by Beinecke Rare Book and Manuscript Library, Yale University and sent per request of the author. 


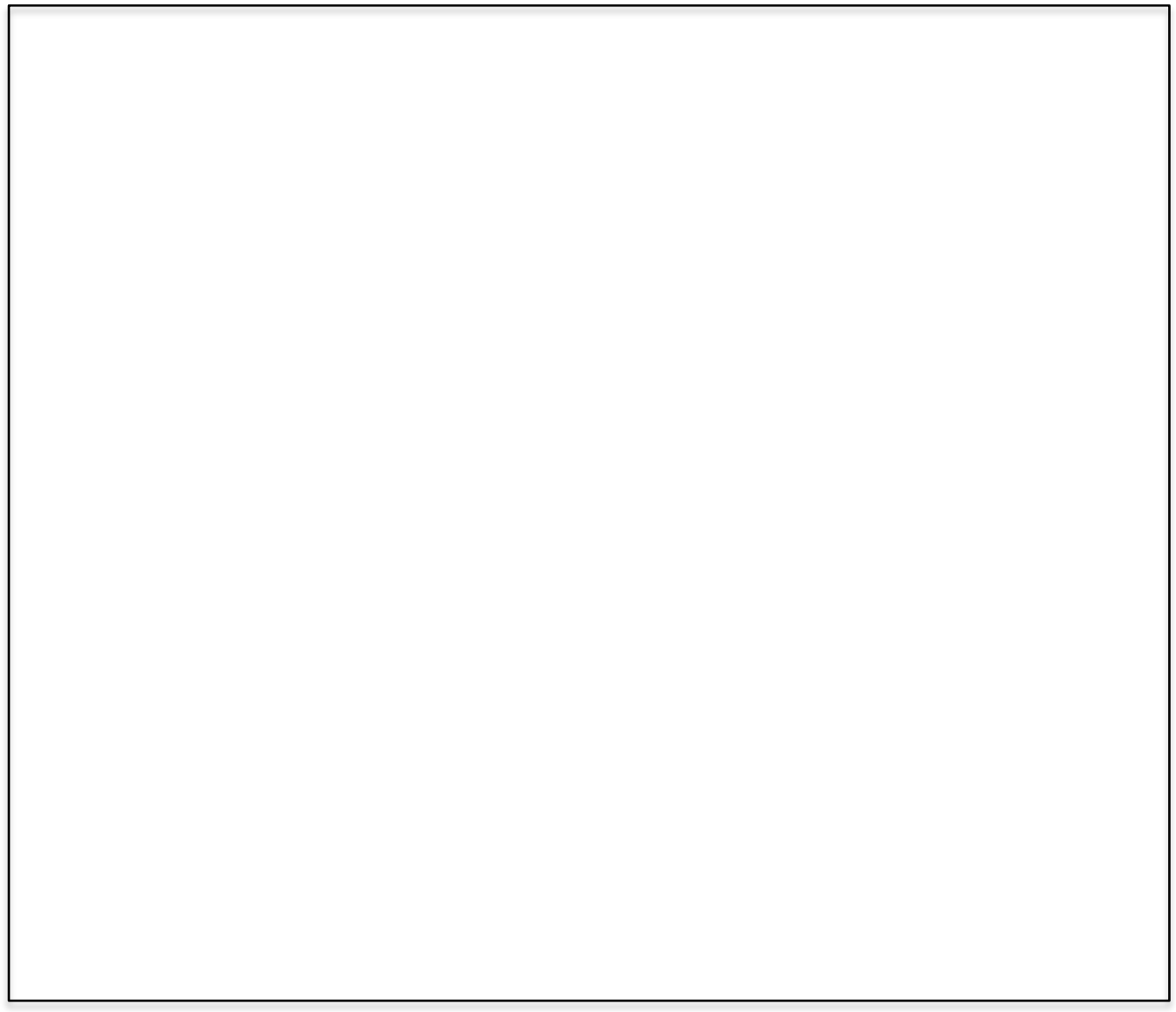

Figure 3.14. Scene nineteen in the Myriopticon, General Grant at Vicksburg. Chromolithography on paper scroll. Reproduced digitally by Beinecke Rare Book and Manuscript Library, Yale University and sent per request of the author. 


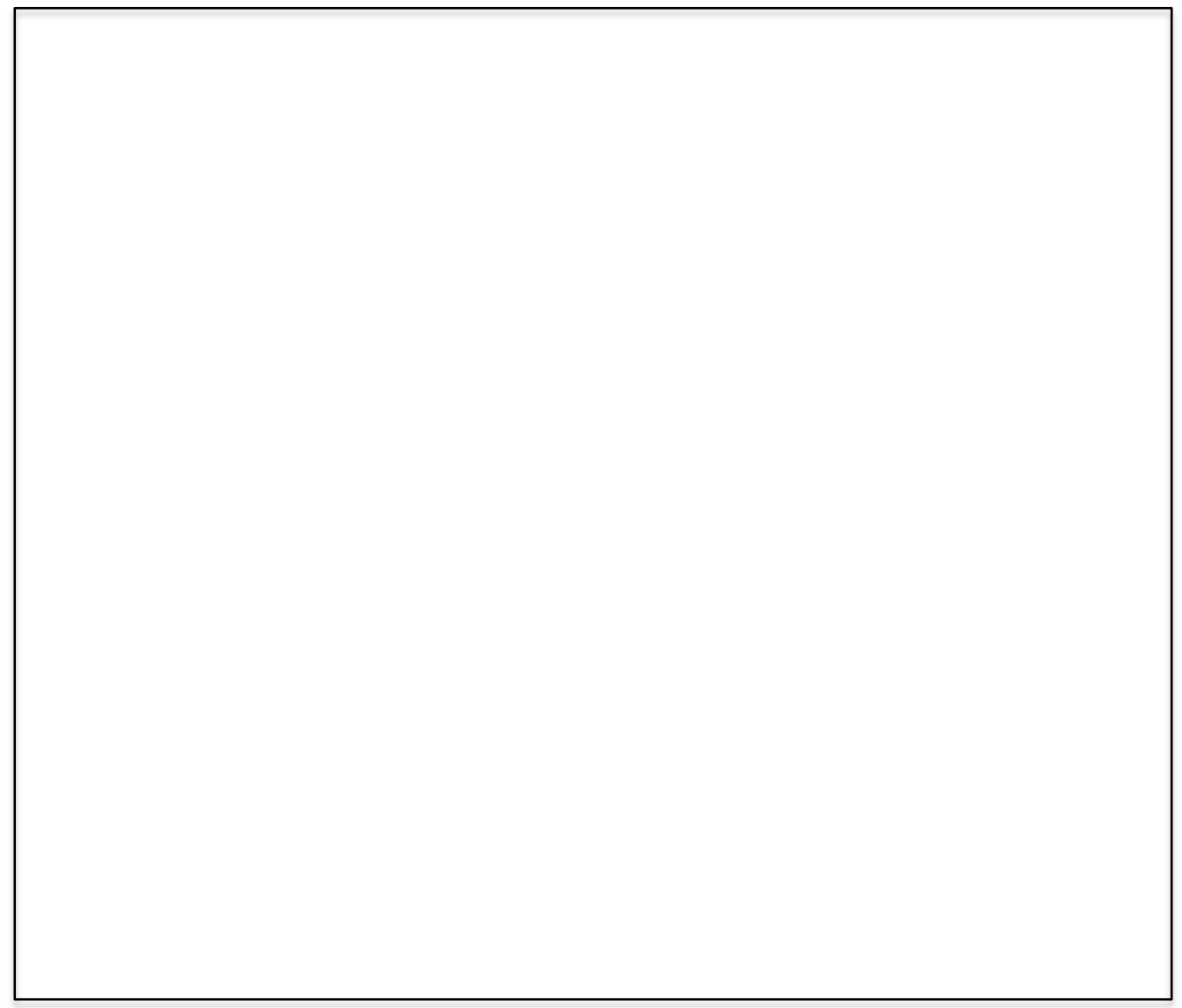

Figure 3.15. Scene twenty in the Myriopticon, Washing up after the Battle of Atlanta. Chromolithography on paper scroll. Reproduced digitally by Beinecke Rare Book and Manuscript Library, Yale University and sent per request of the author. 
Figure 3.16. Scene twenty-two in the Myriopticon, Sinking of the 'Alabama.' Chromolithography on paper scroll. Reproduced digitally by Beinecke Rare Book and Manuscript Library, Yale University and sent per request of the author. 


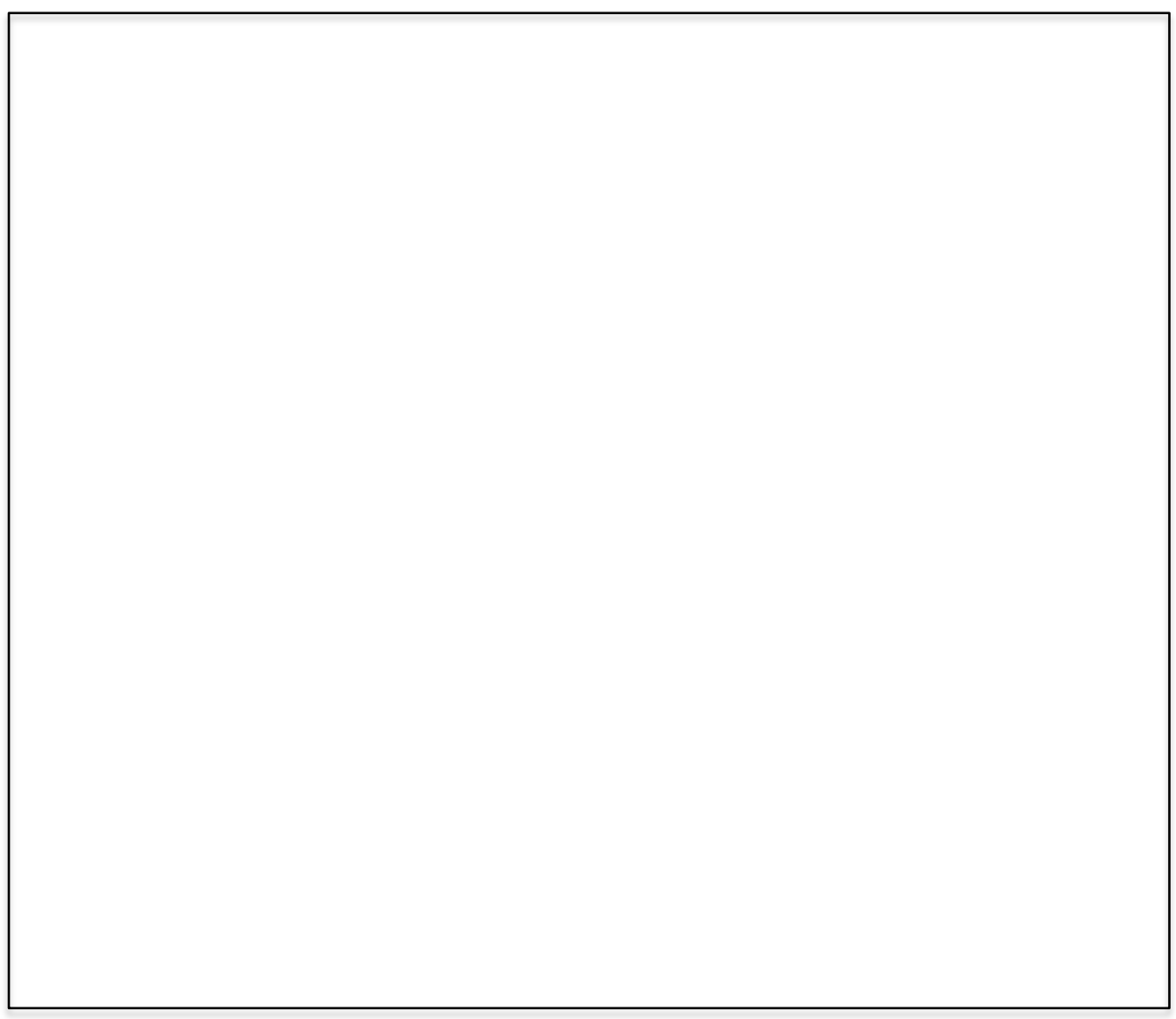

Figure 3.17. “The Sinking of the 'Alabama' off Cherbourg, June 19, 1864," Harper's Weekly VIII, no. 395 (July 23, 1864): 465. Wood engraving. Reproduced digitally by Illustrated Civil War Newspapers and Magazines.

staging-lincolnandthecivilwar-com.proxy.mul.missouri.edu/BrowseTitle.asp 


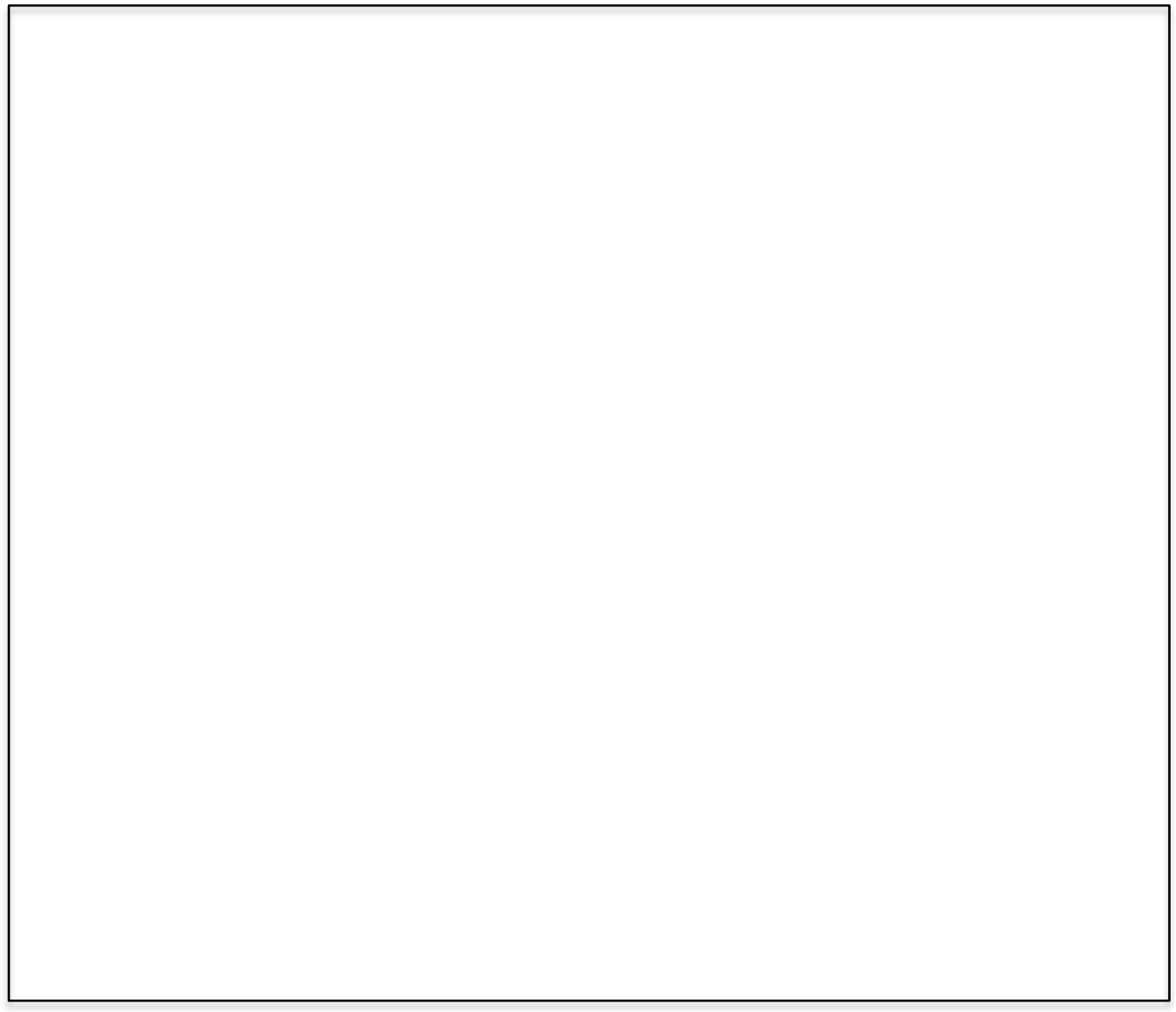

Figure 3.18. Scene twenty-four in the Myriopticon, Burning of Richmond. Chromolithography on paper scroll. Reproduced digitally by Beinecke Rare Book and Manuscript Library, Yale University and sent per request of the author. 


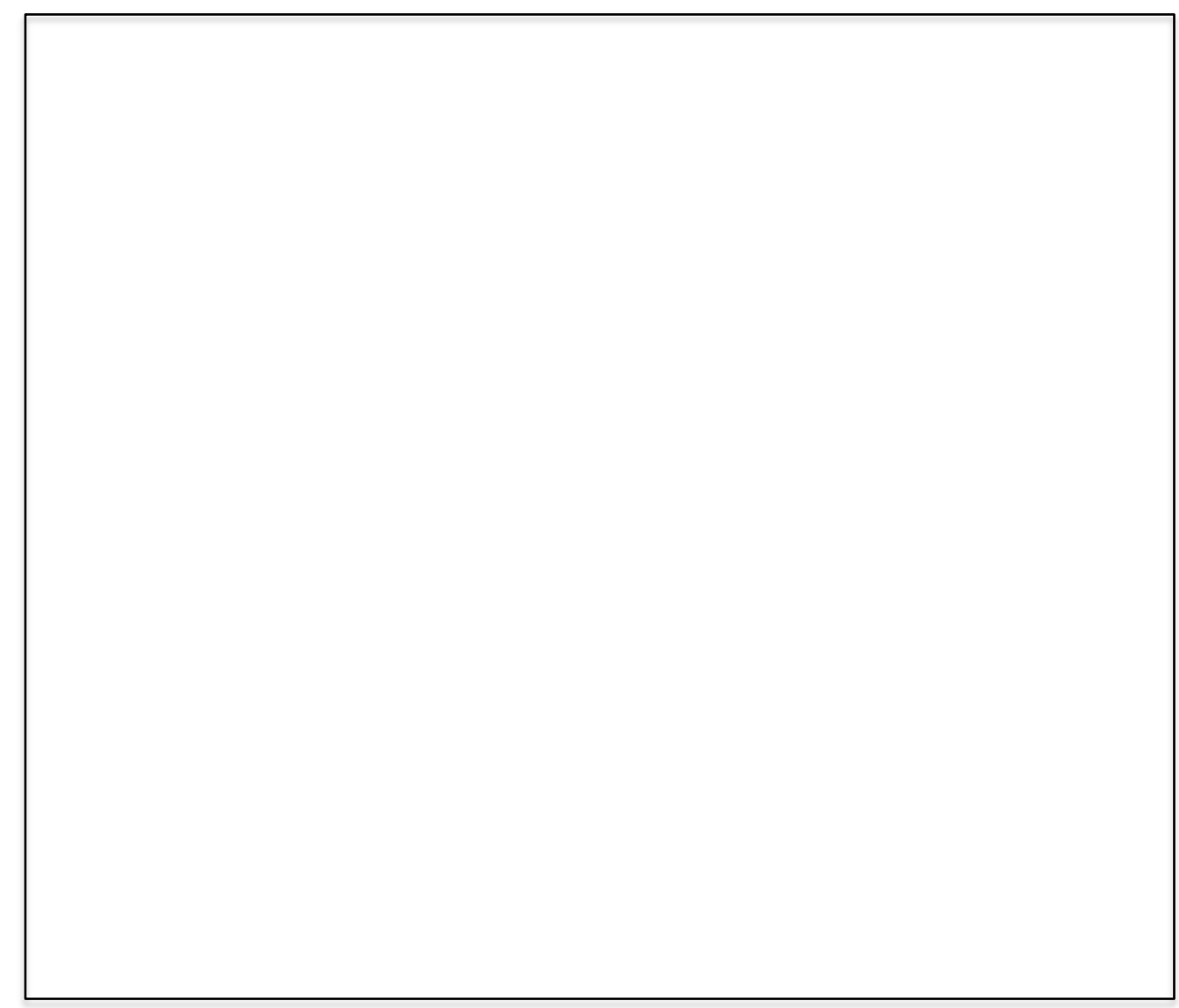

Figure 4.1. Scene one in the Historiscope, A group of Native Americans.

Chromolithographed on paper scroll. Reproduced digitally by Beinecke Rare Book and Manuscript Library, Yale University and sent per request of the author. 
Figure 4.2. Juncture between scene one and scene two in the Historiscope. Chromolithographed on paper scroll. Reproduced digitally by www.antiquetoysandgames.com 


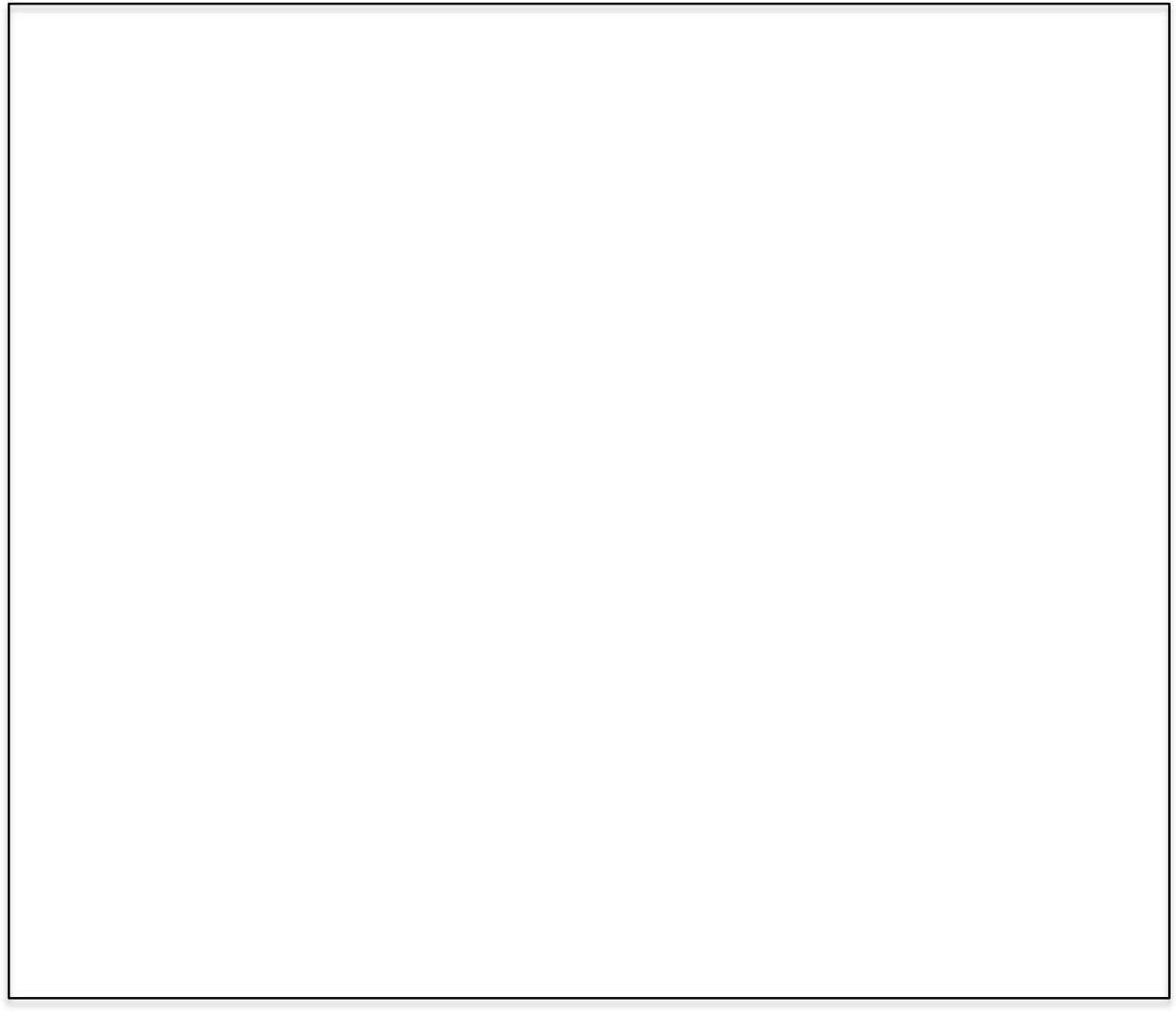

Figure 4.3. Scene two in the Historiscope, Landing of Columbus.

Chromolithographed on paper scroll. Reproduced digitally by Beinecke Rare Book and Manuscript Library, Yale University and sent per request of the author. 


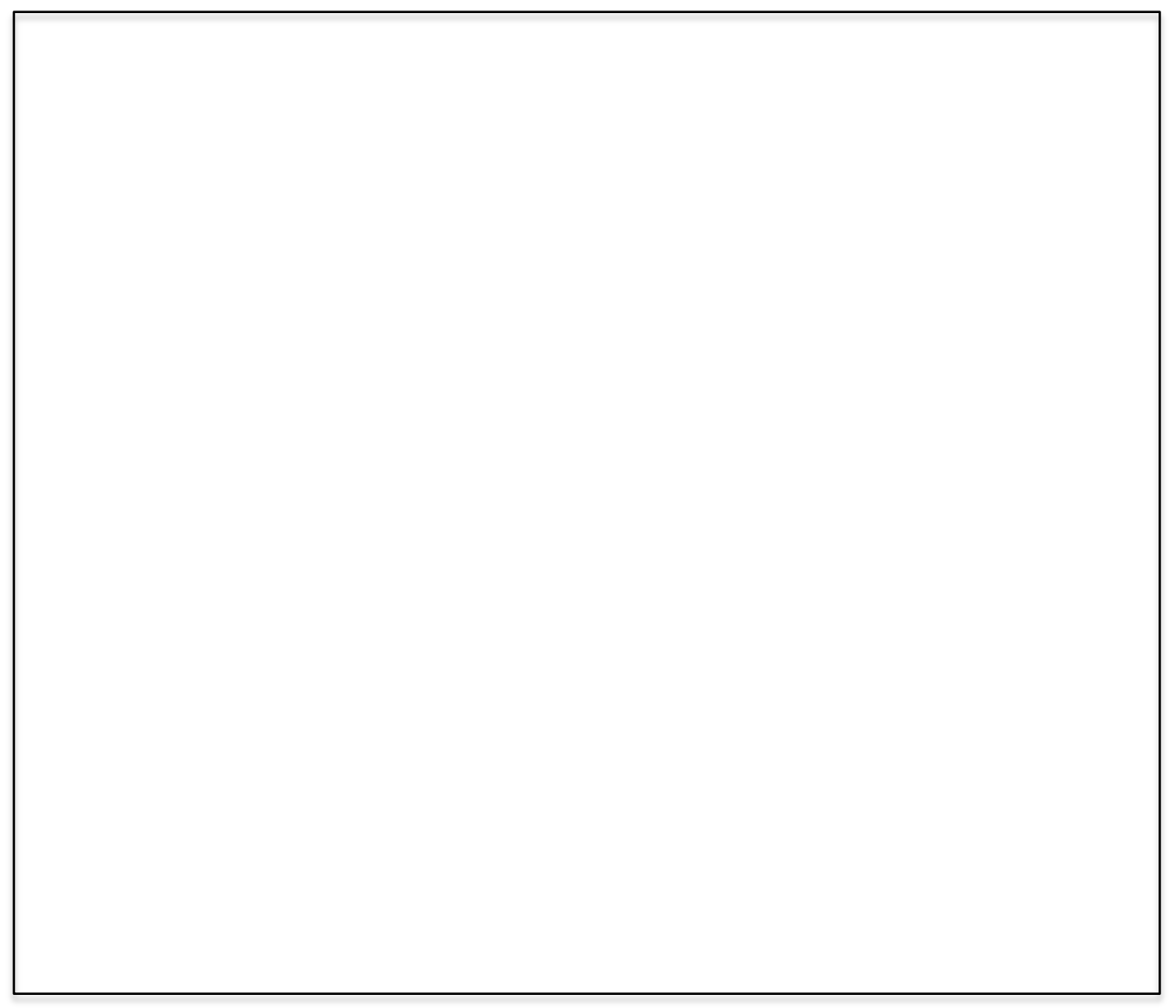

Figure 4.4. Scene three in the Historiscope, Discovery of the Mississippi River by De Soto. Chromolithographed on paper scroll. Reproduced digitally by Beinecke Rare Book and Manuscript Library, Yale University and sent per request of the author. 


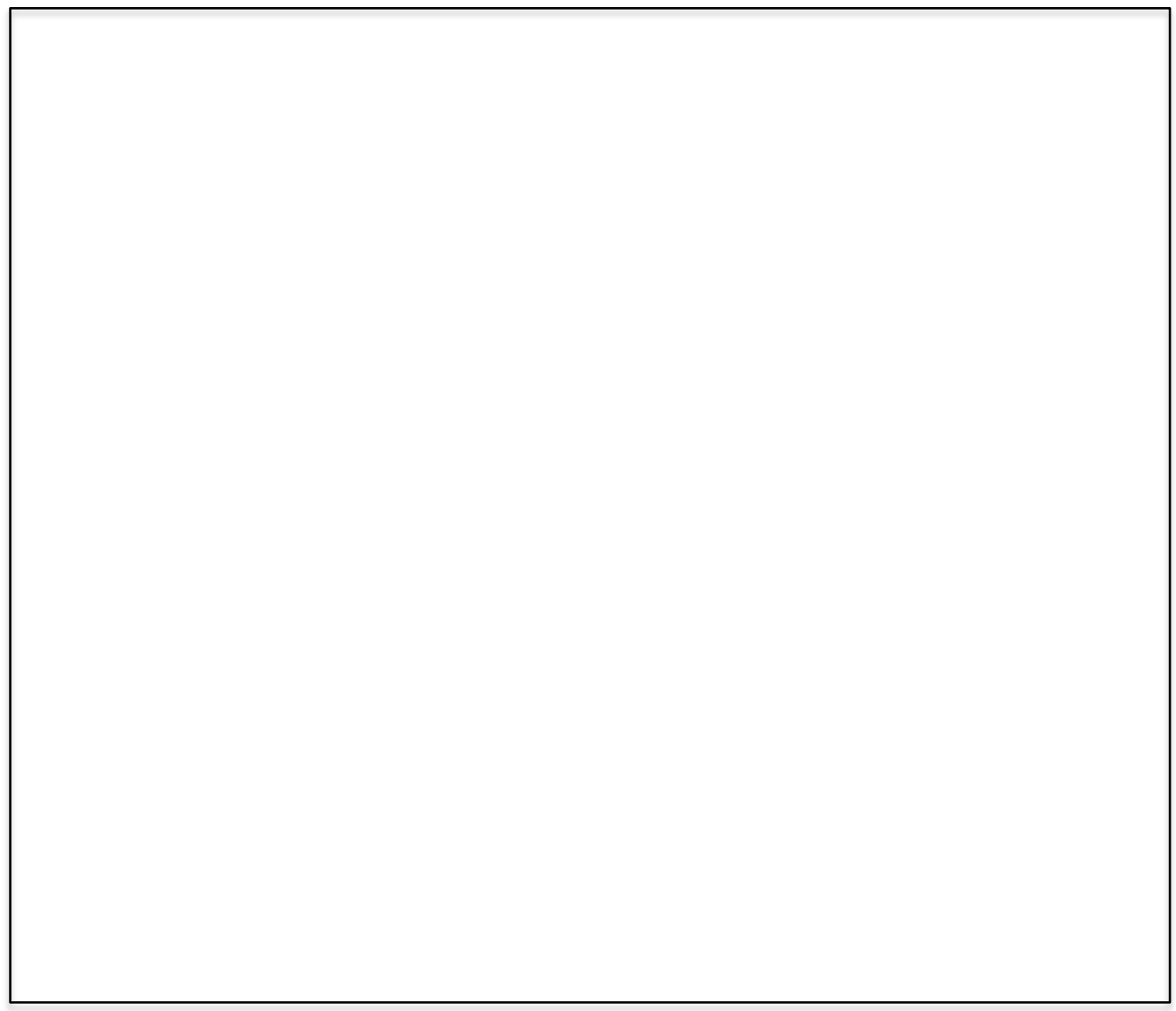

Figure 4.5. Scene four in the Historiscope, Discover of the Hudson River. Chromolithographed on paper scroll. Reproduced digitally by Beinecke Rare Book and Manuscript Library, Yale University and sent per request of the author. 


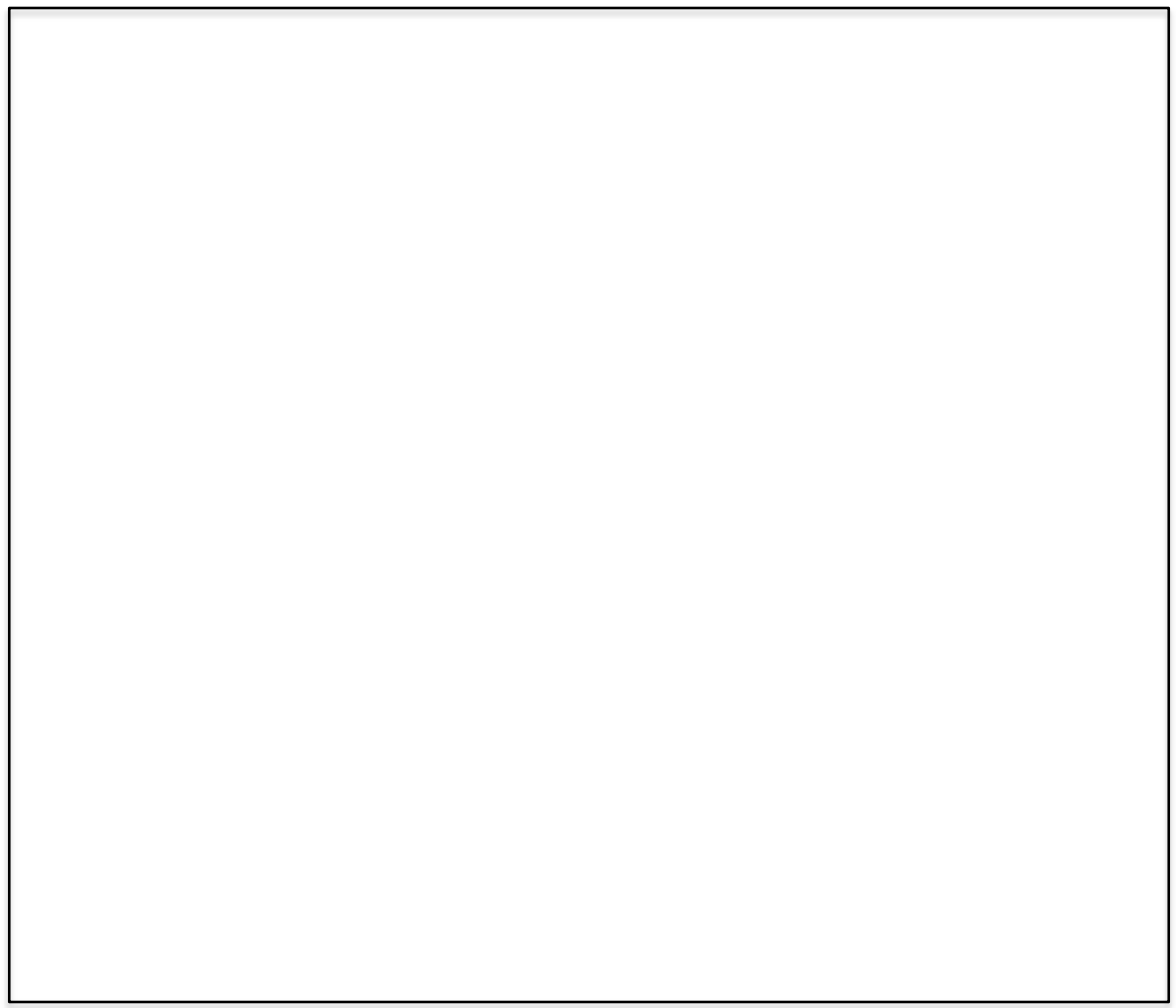

Figure 4.6. Scene five in the Historiscope, Settlement of Jamestown, Virginia. Chromolithographed on paper scroll. Reproduced digitally by Beinecke Rare Book and Manuscript Library, Yale University and sent per request of the author. 


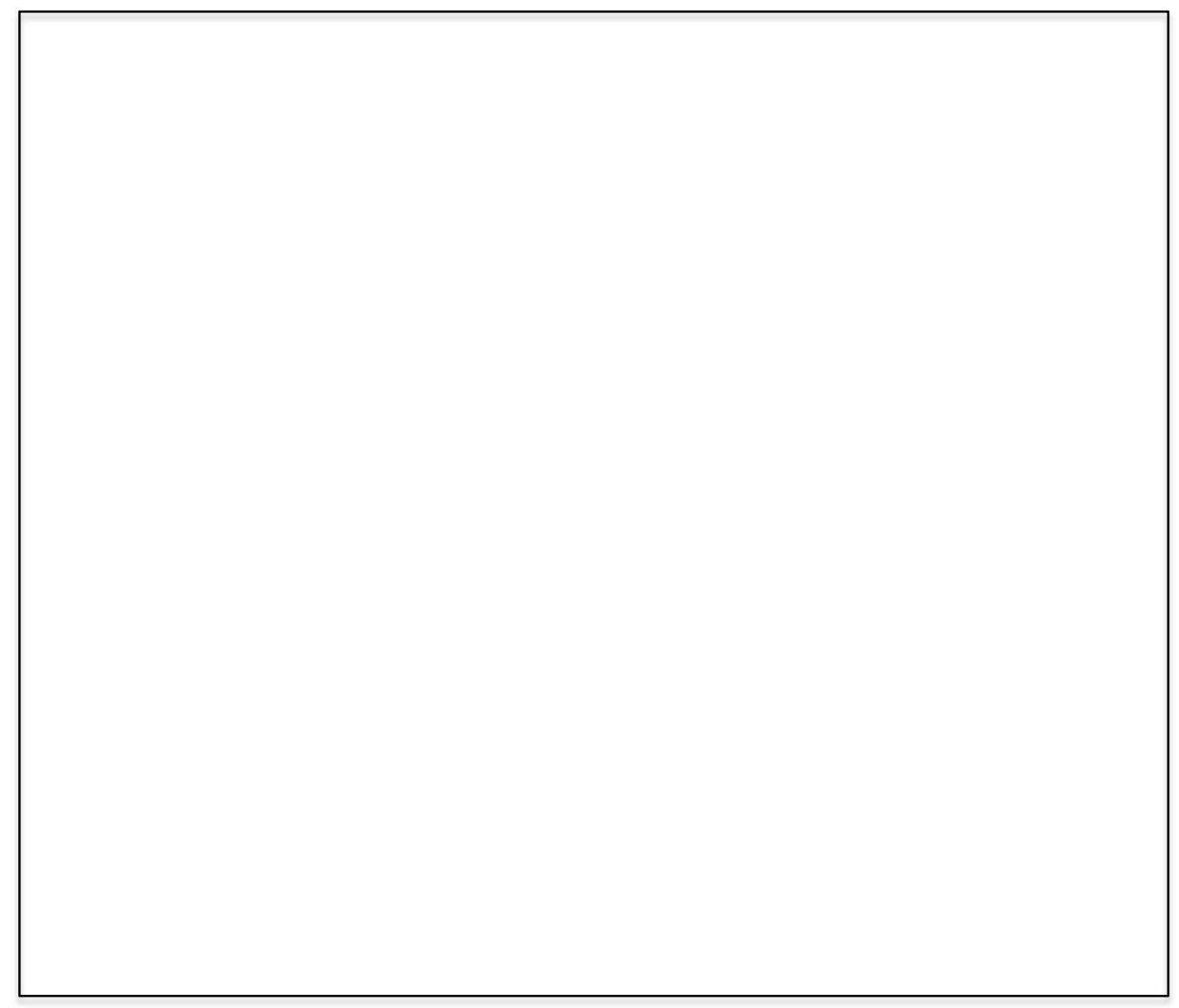

Figure 4.7. Scene six in the Historiscope, Pocahontas saving Captain John Smith. Chromolithographed on paper scroll. Reproduced digitally by Beinecke Rare Book and Manuscript Library, Yale University and sent per request of the author. 


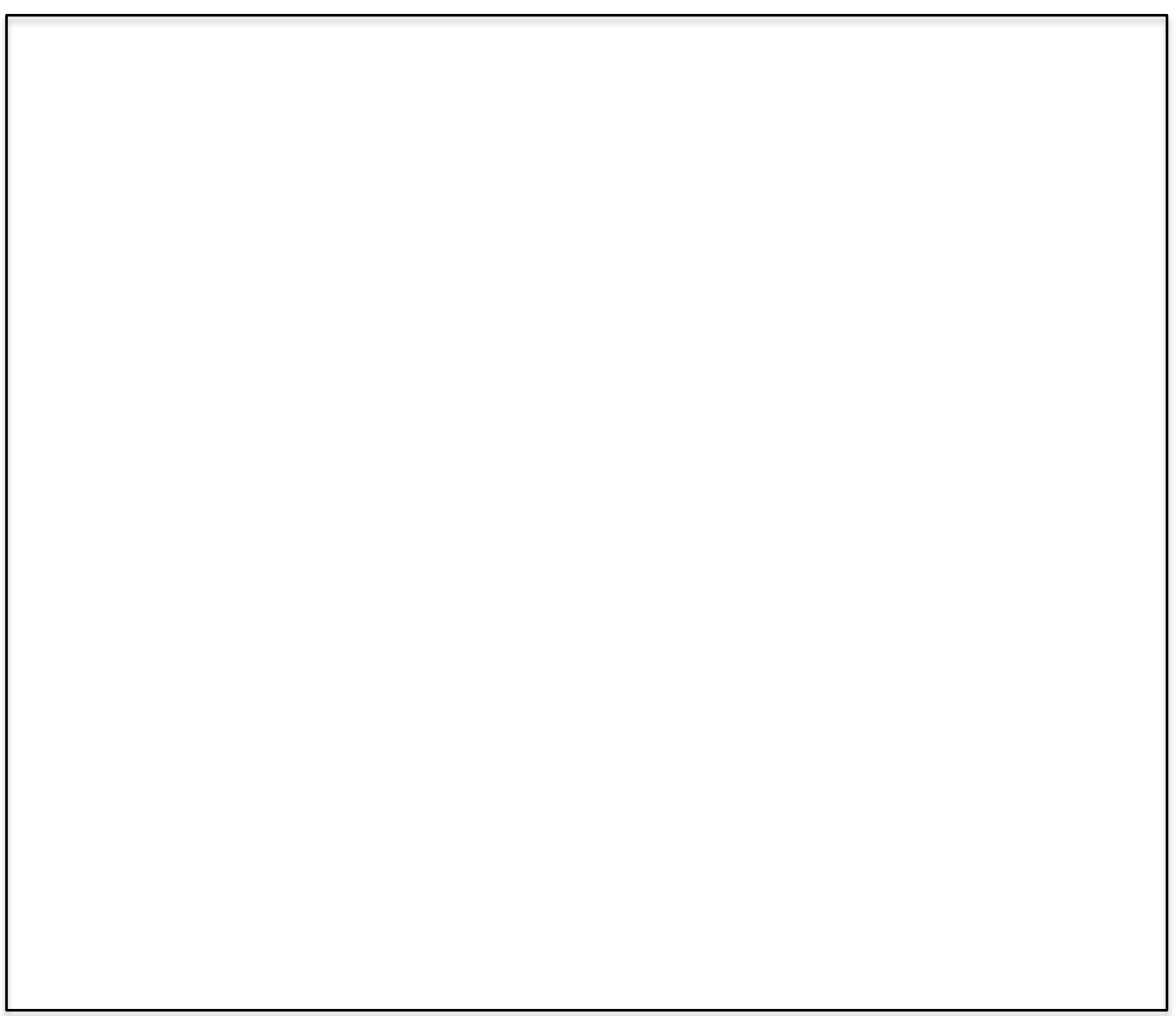

Figure 4.8. Scene seven in the Historiscope, Landing of the Pilgrims. Chromolithographed on paper scroll. Reproduced digitally by Beinecke Rare Book and Manuscript Library, Yale University and sent per request of the author. 


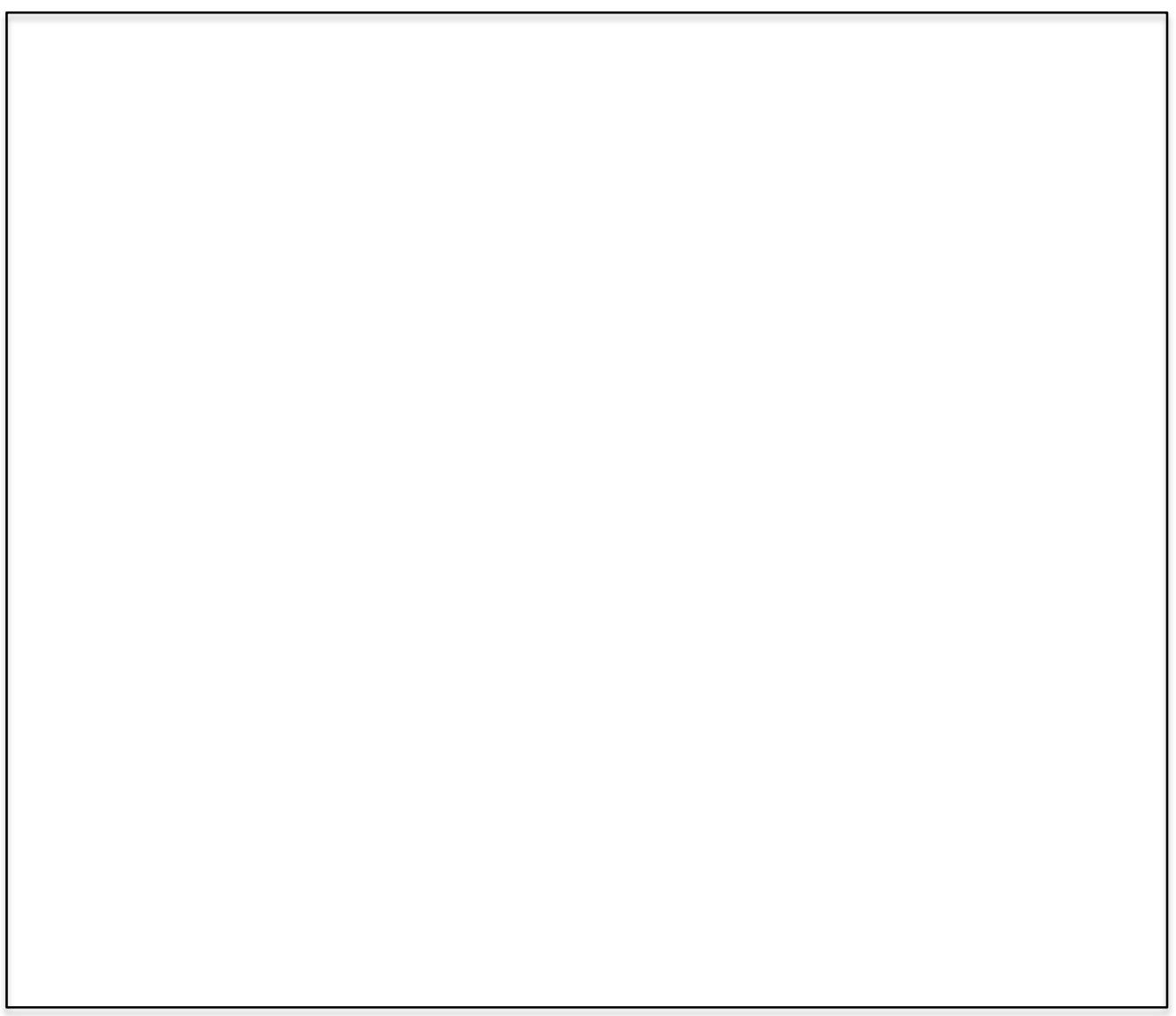

Figure 4.9. Scene eight in the Historiscope, City of New York. Chromolithographed on paper scroll. Reproduced digitally by Beinecke Rare Book and Manuscript Library, Yale University and sent per request of the author. 


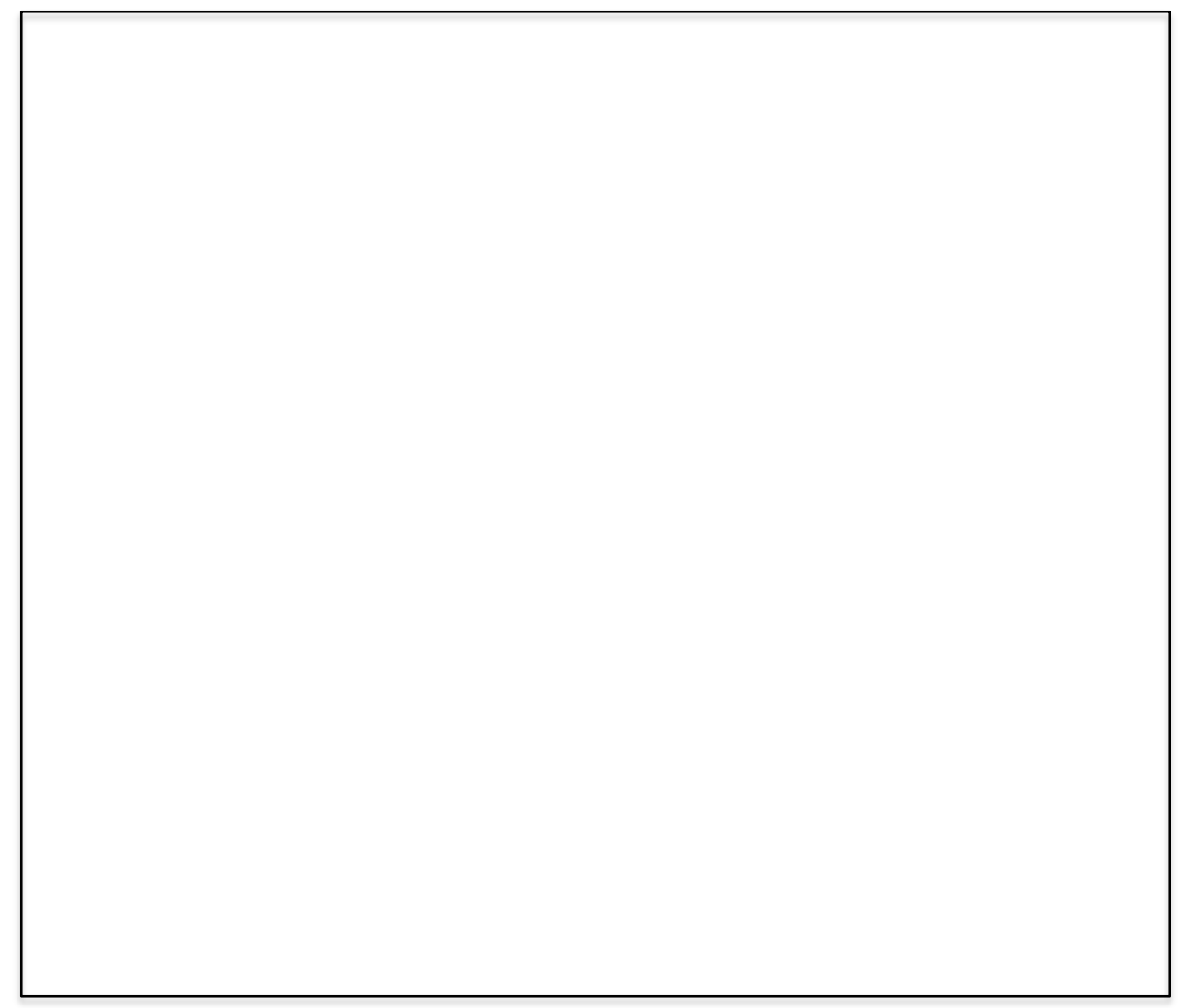

Figure 4.10. Scene nine in the Historiscope, Treaty of William Penn with the Indians, 1682. Chromolithographed on paper scroll. Reproduced digitally by Beinecke Rare Book and Manuscript Library, Yale University and sent per request of the author. 
Figure 4.11. Scene ten in the Historiscope, Roger Williams Pleading with the sachem of the Narragansetts. Chromolithographed on paper scroll. Reproduced digitally by Beinecke Rare Book and Manuscript Library, Yale University and sent per request of the author. 


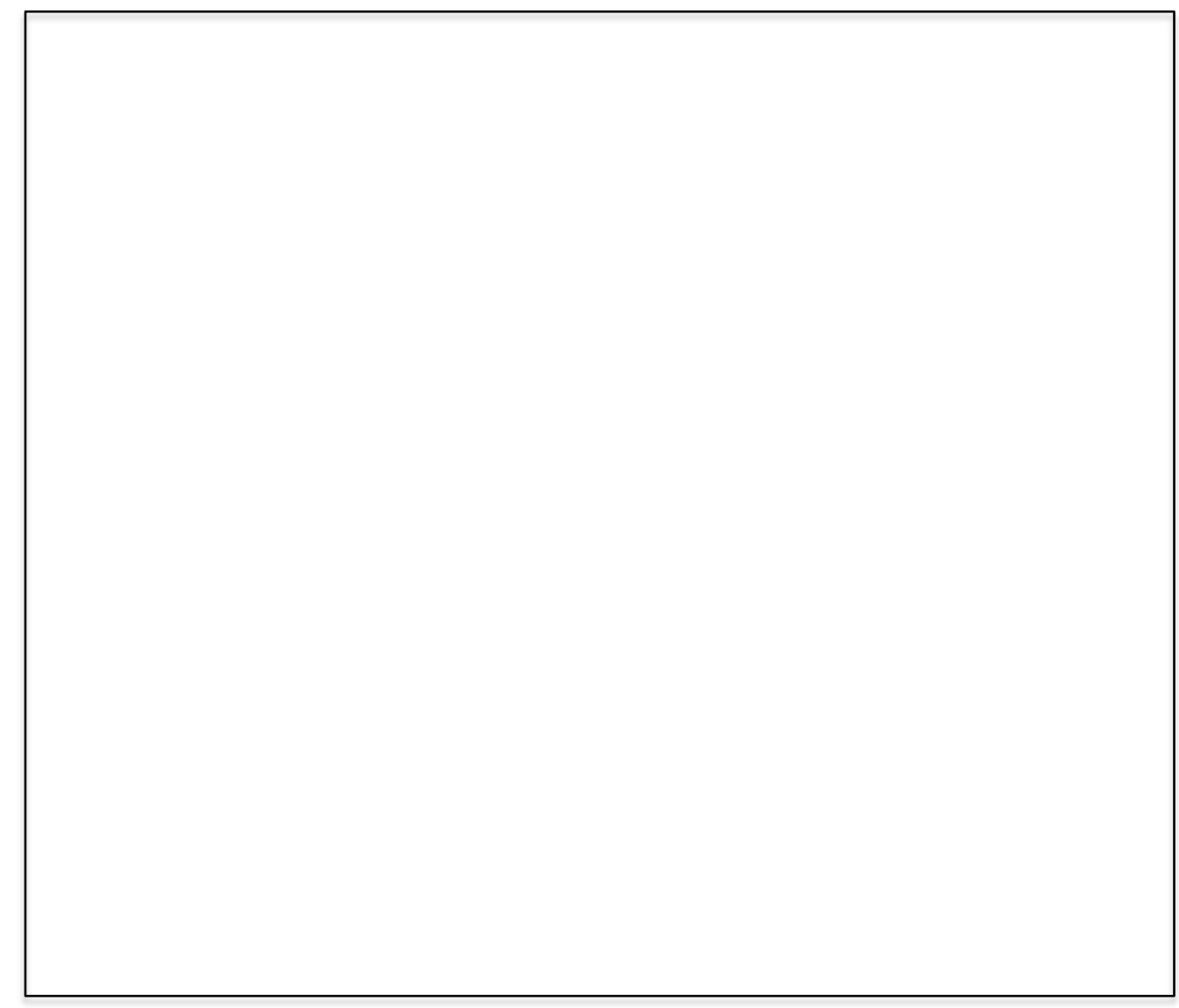

Figure 4.12. Scene eleven in the Historiscope, Palisaded house.

Chromolithographed on paper scroll. Reproduced digitally by Beinecke Rare Book and Manuscript Library, Yale University and sent per request of the author. 


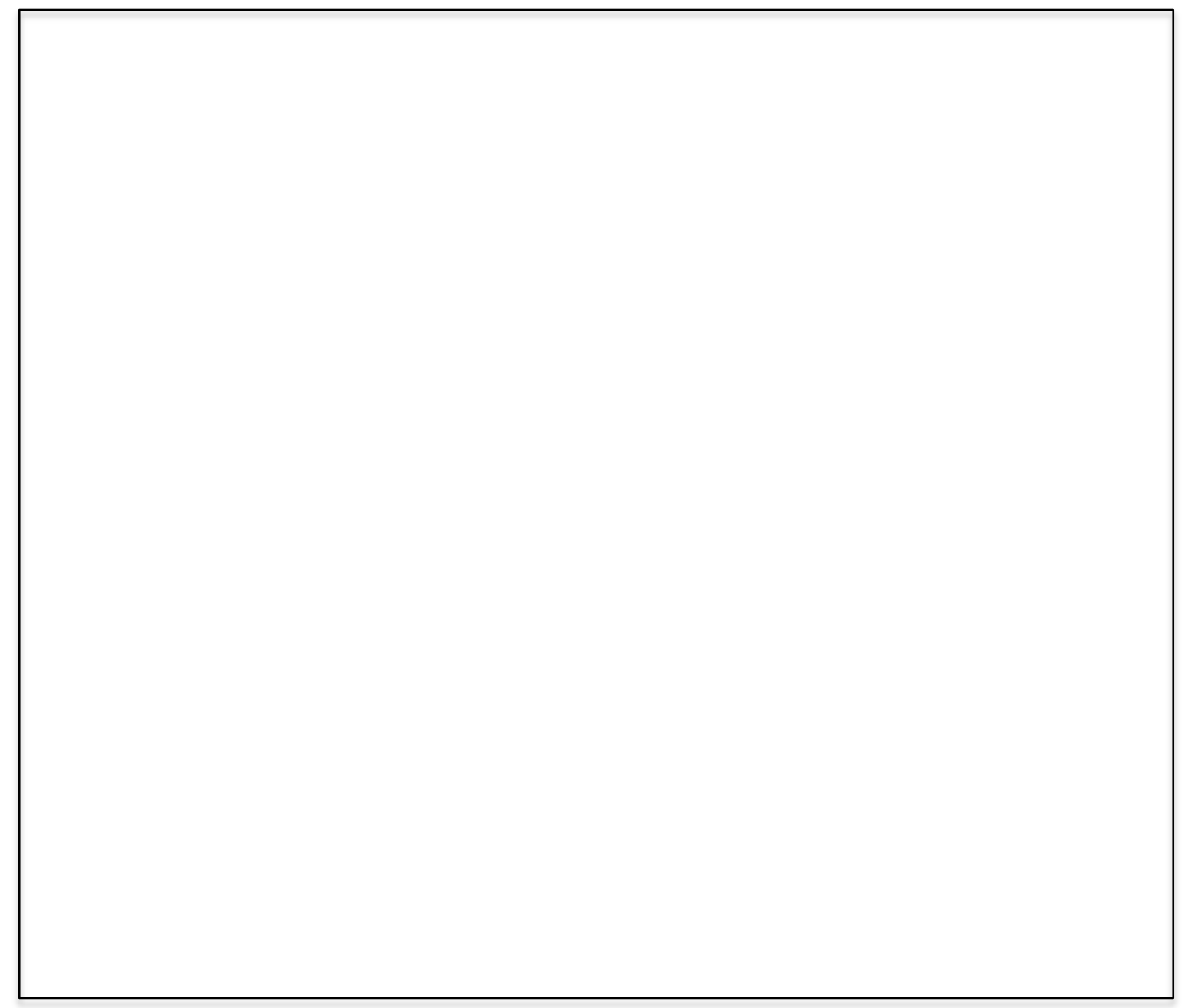

Figure 4.13. Charles A. Goodrich, History of the United States of America; for Use of Schools; revised and brought down to the present time by William H. Seavey, principal of the Girl's High and Normal School, Boston (New York: Taintor Brothers, Merrill and Co., 1867), 43. Reproduced digitally by HathiTrust

babel.hathitrust.org/cgi/pt?id=loc.ark:/13960/t79s24217\&view=1up\&seq=5 


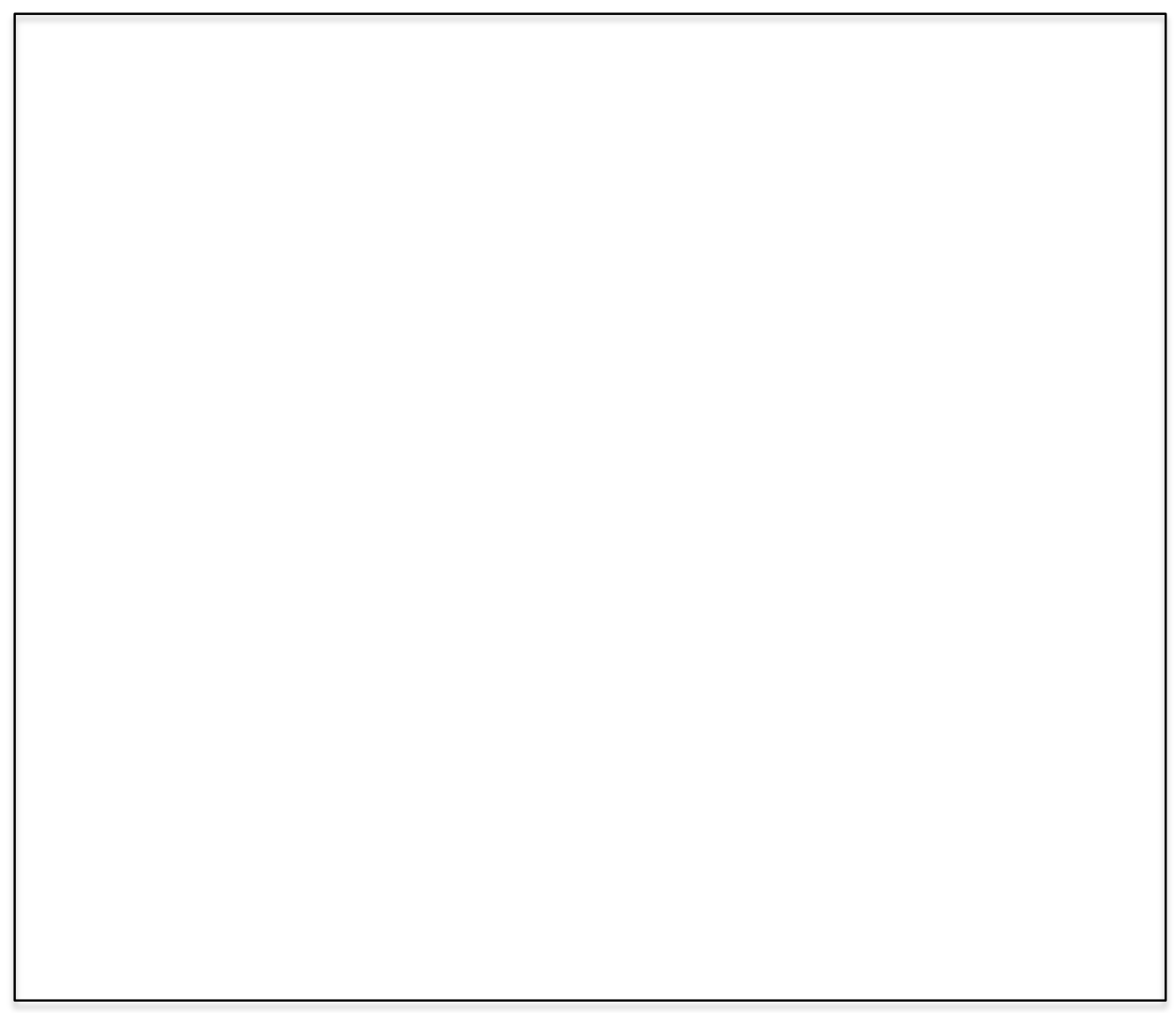

Figure 4.14. Scene twelve in the Historiscope, Block-house, Kennebec, Maine. Chromolithographed on paper scroll. Reproduced digitally by Beinecke Rare Book and Manuscript Library, Yale University and sent per request of the author. 


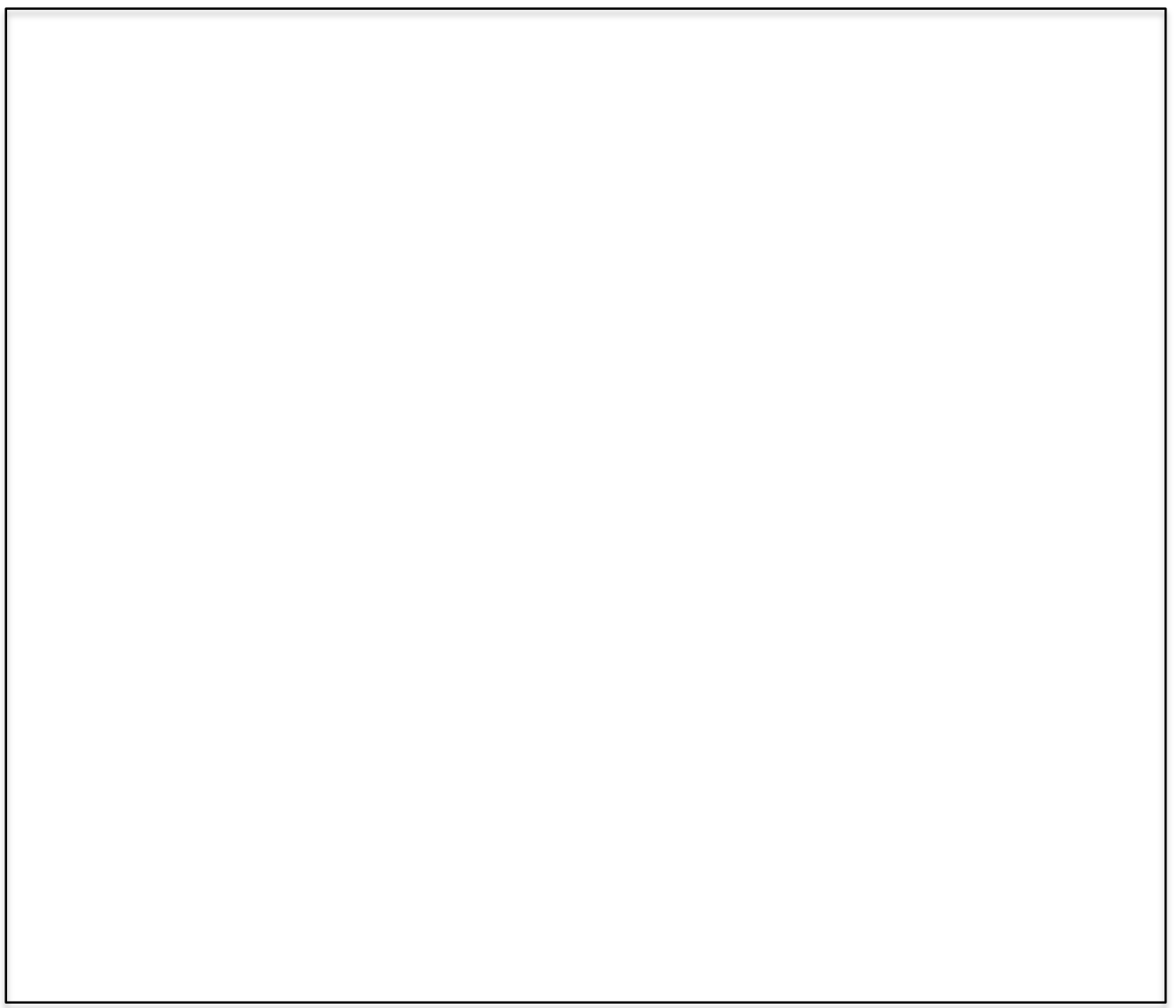

Figure 4.15. Scene thirteen in the Historiscope, Wadsworth hiding the Charter of Connecticut. Chromolithographed on paper scroll. Reproduced digitally by Beinecke Rare Book and Manuscript Library, Yale University and sent per request of the author. 


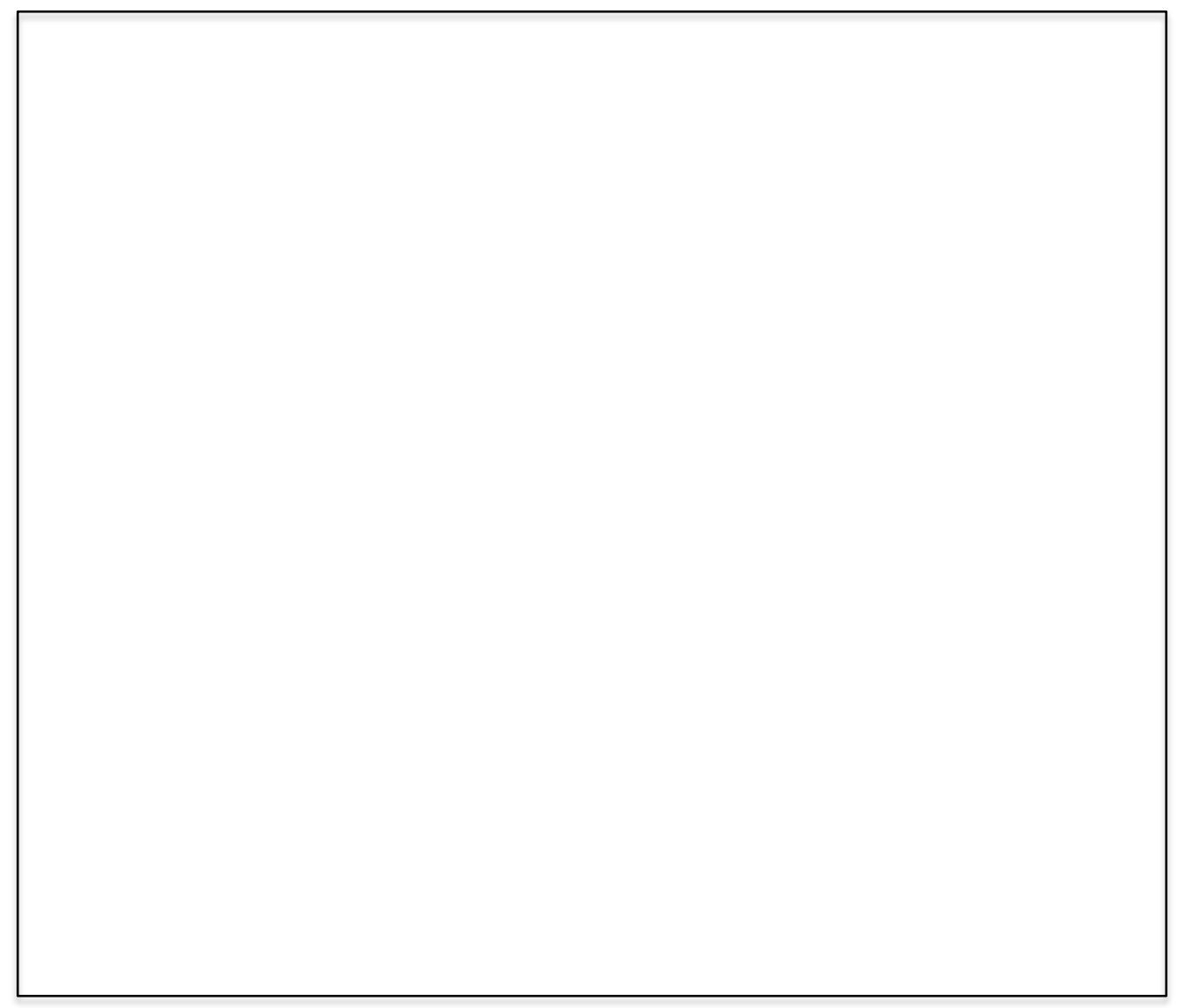

Figure 4.16. Scene fourteen in the Historiscope, Boston tea party. Chromolithographed on paper scroll. Reproduced digitally by Beinecke Rare Book and Manuscript Library, Yale University and sent per request of the author. 


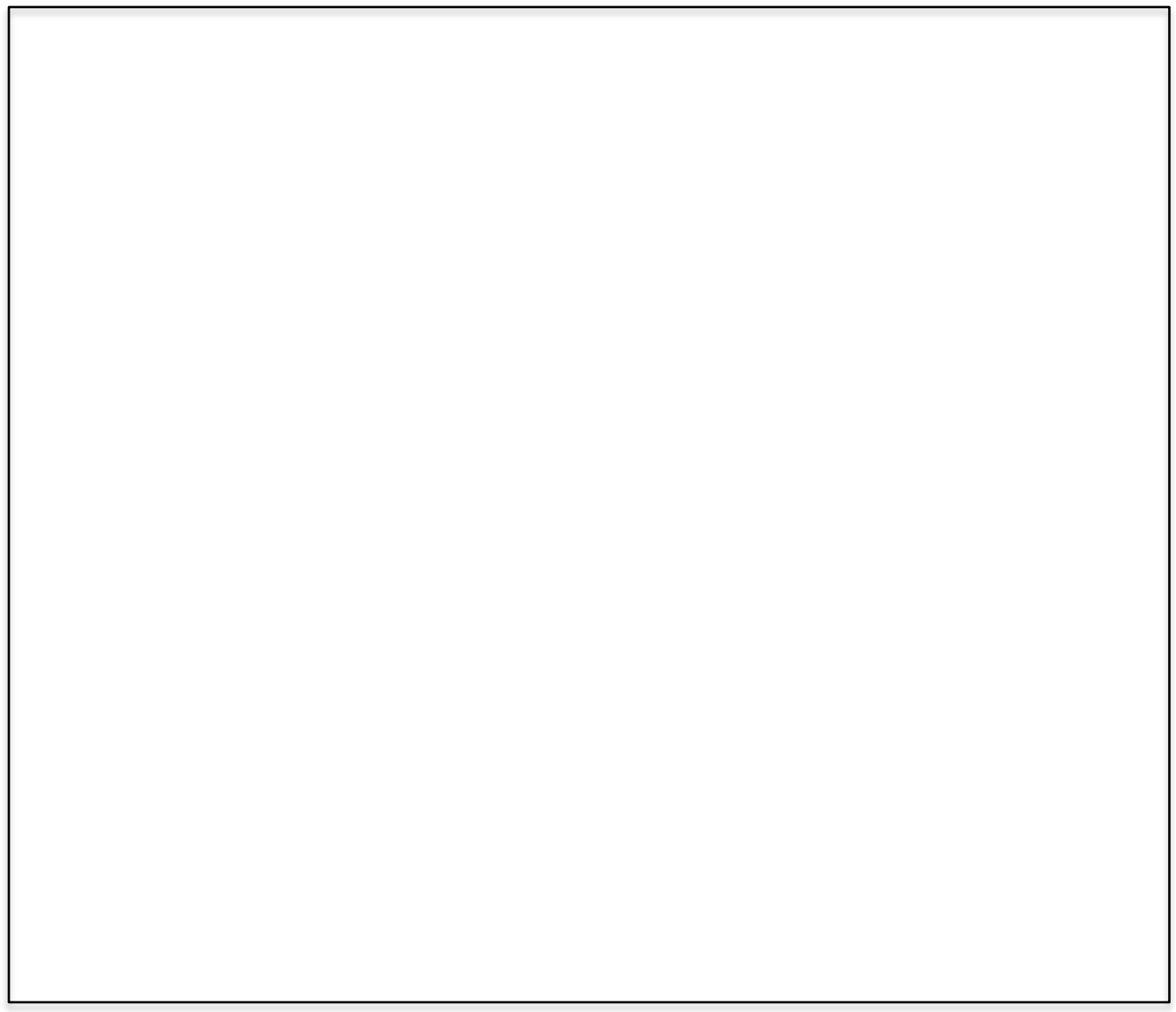

Figure 4.17. Scene fifteen in the Historiscope, Battle of Lexington. Chromolithographed on paper scroll. Reproduced digitally by Beinecke Rare Book and Manuscript Library, Yale University and sent per request of the author. 


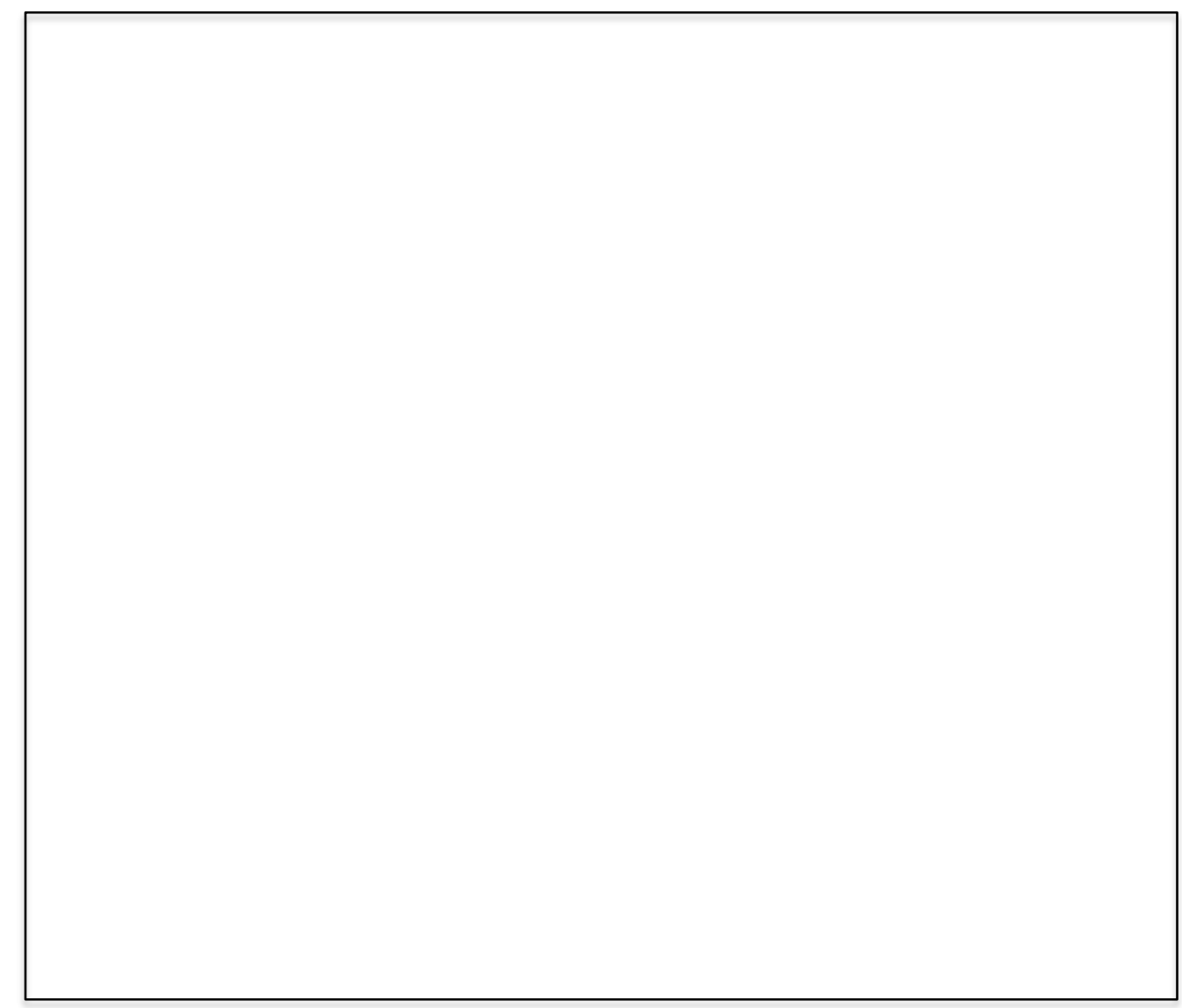

Figure 4.18. Scene sixteen in the Historiscope, The Battle of Bunker Hill. Chromolithographed on paper scroll. Reproduced digitally by Beinecke Rare Book and Manuscript Library, Yale University and sent per request of the author. 


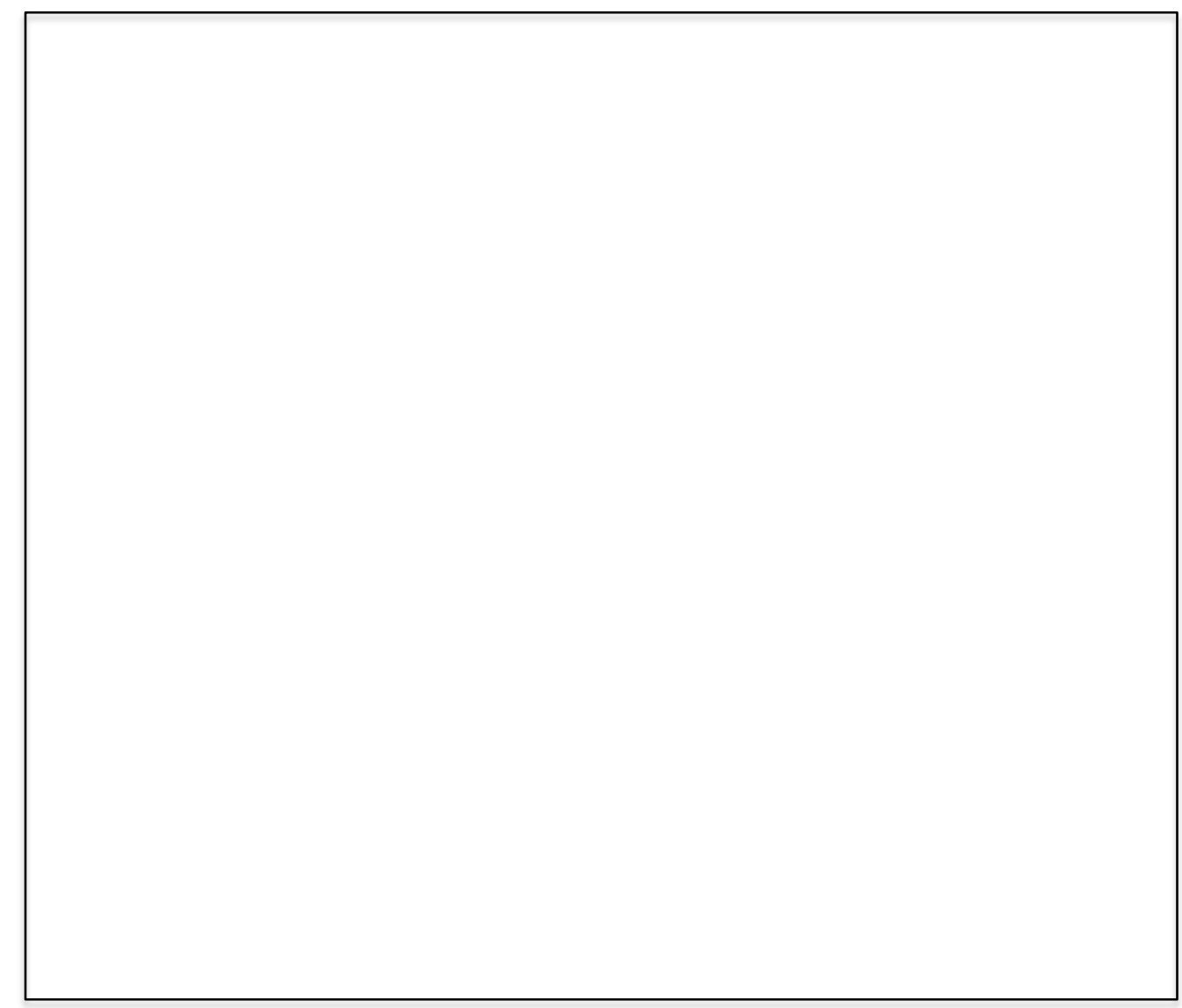

Figure 4.19. John Trumbull, The Death of General Warren at the Battle of Bunker Hill, June 17, 1775, oil on canvas, 1813-1831 (several versions made); Trumbull sold the engraving rights. Reproduced digitally by Wikimedia Commons https://commons.wikimedia.org/w/index.php?search $=$ The + death + of + general + warren + at + the + battle + of + bu

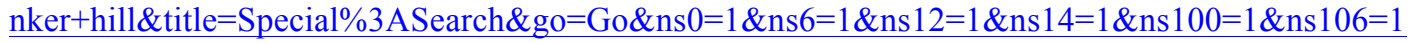




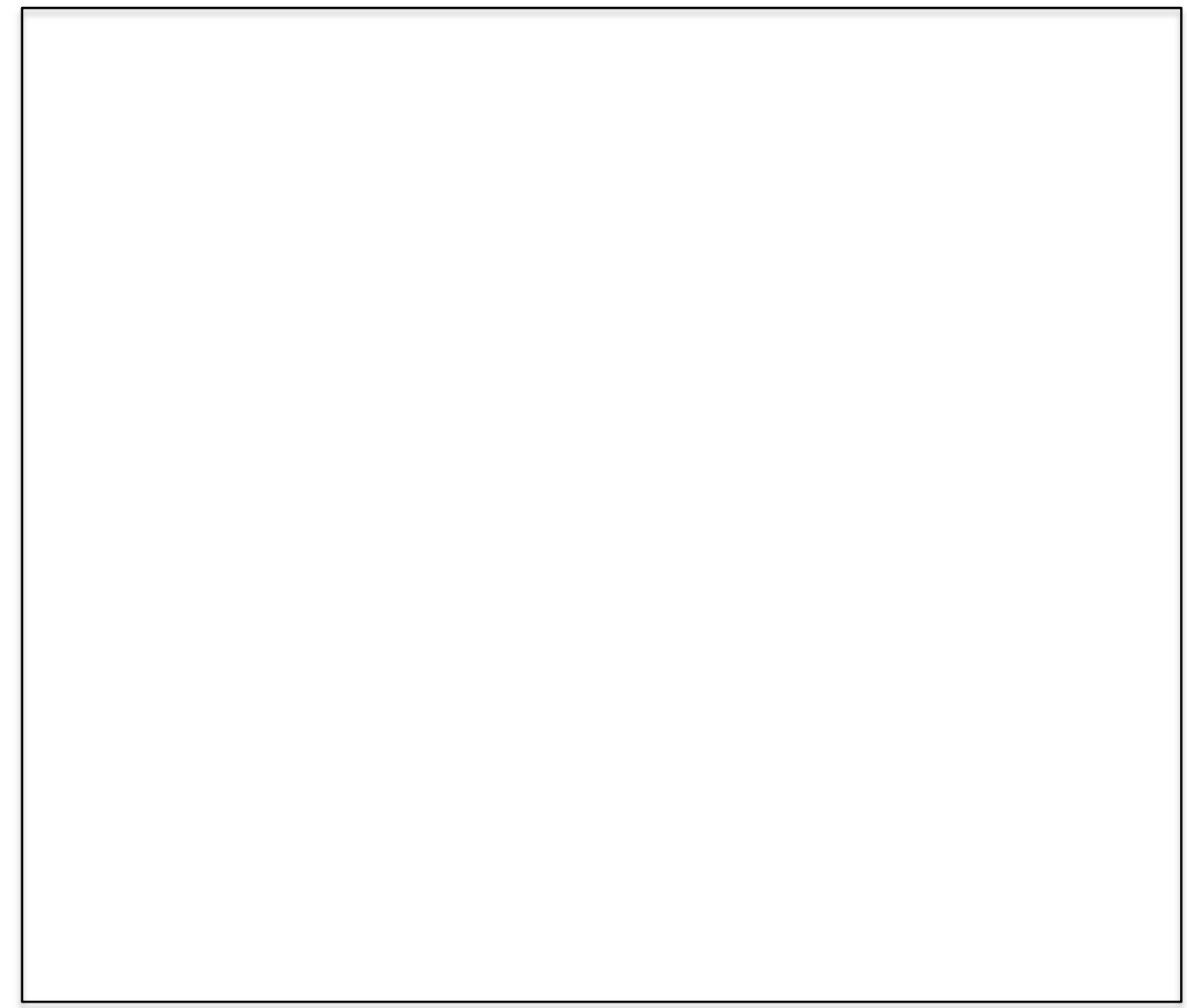

Figure 4.20. Charles A. Goodrich, History of the United States

of America; for Use of Schools; revised and brought down to the present time by William H. Seavey, principal of the Girl's High and Normal School,

Boston (New York: Taintor Brothers, Merrill and Co.,1867), 116. Reproduced digitally by HathiTrust

babel.hathitrust.org/cgi/pt?id=loc.ark:/13960/t79s24217\&view=1up\&seq=5 


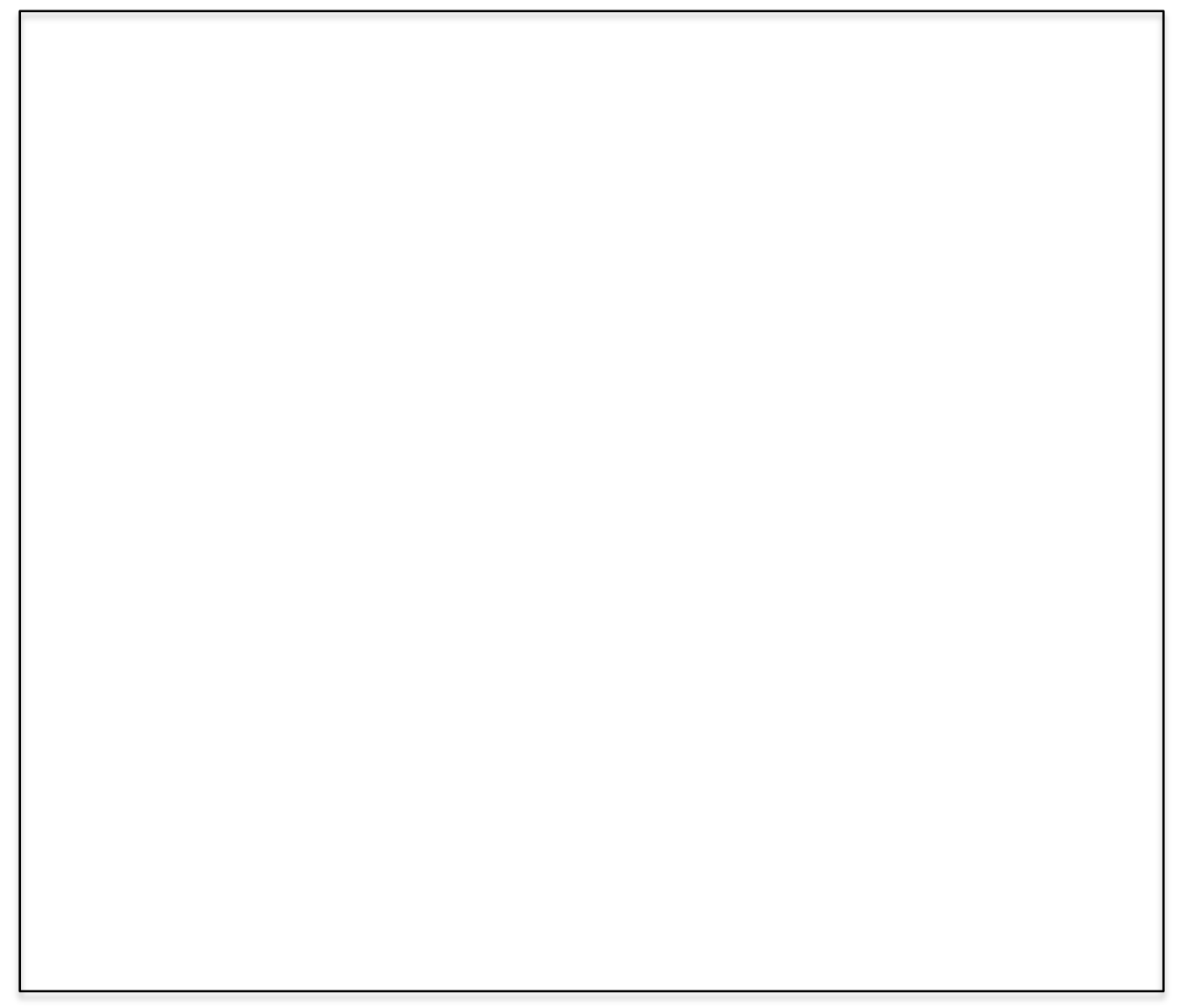

Figures 4.21. Scene seventeen in the Historiscope, Bunker Hill monument. Chromolithographed on paper scroll. Reproduced digitally by Beinecke Rare Book and Manuscript Library, Yale University and sent per request of the author.

Figure 4.22. Scene eighteen in the Historiscope, General George Washington as Commander-in-Chief of the American Army. Reproduced digitally by Beinecke Rare Book and Manuscript Library, Yale University and sent per request of the author. 


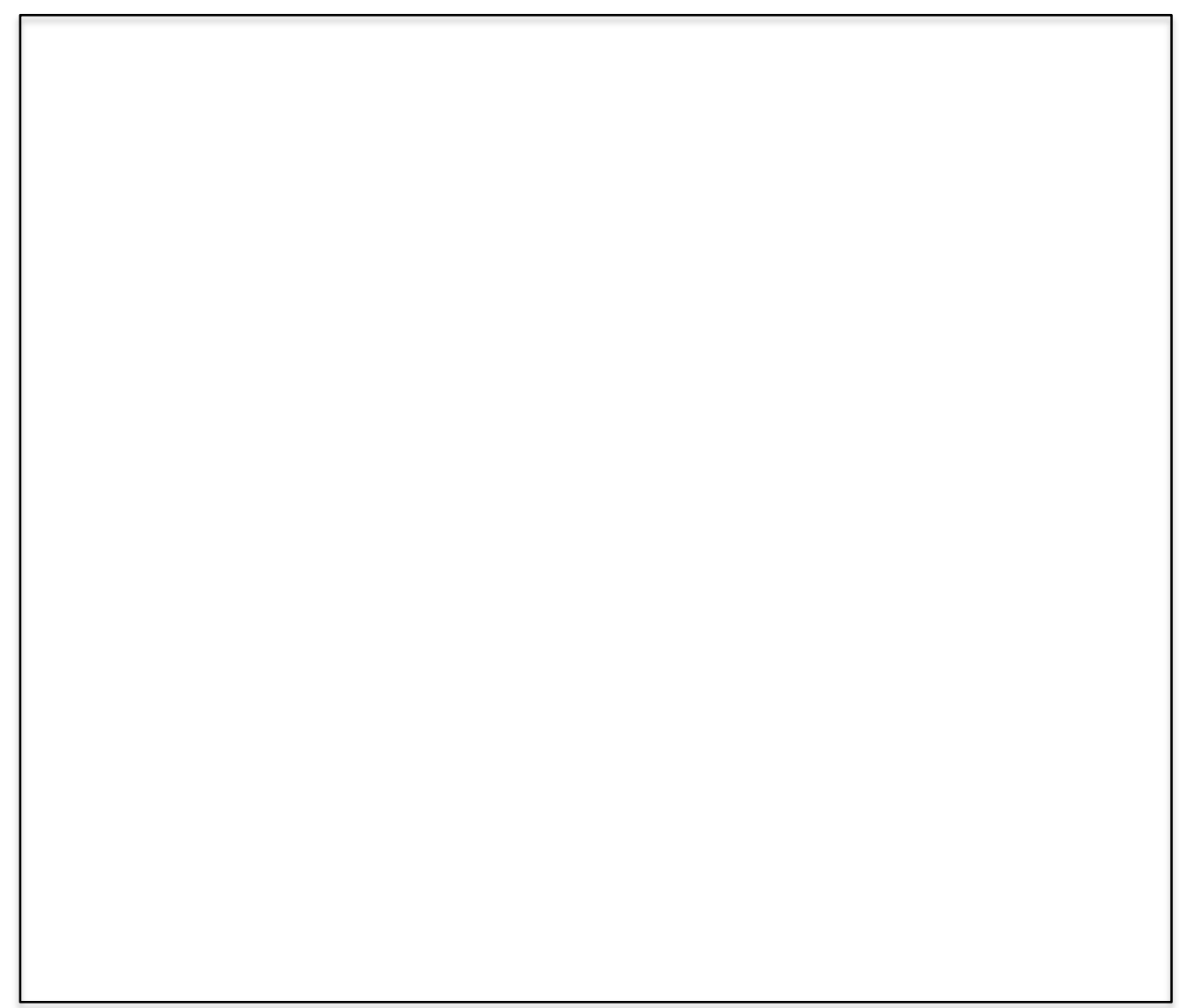

Figure 4.23. Scene nineteen in the Historiscope, Attack on Quebec by the American Army. Chromolithographed on paper scroll. Reproduced digitally by Beinecke Rare Book and Manuscript Library, Yale University and sent per request of the author. 


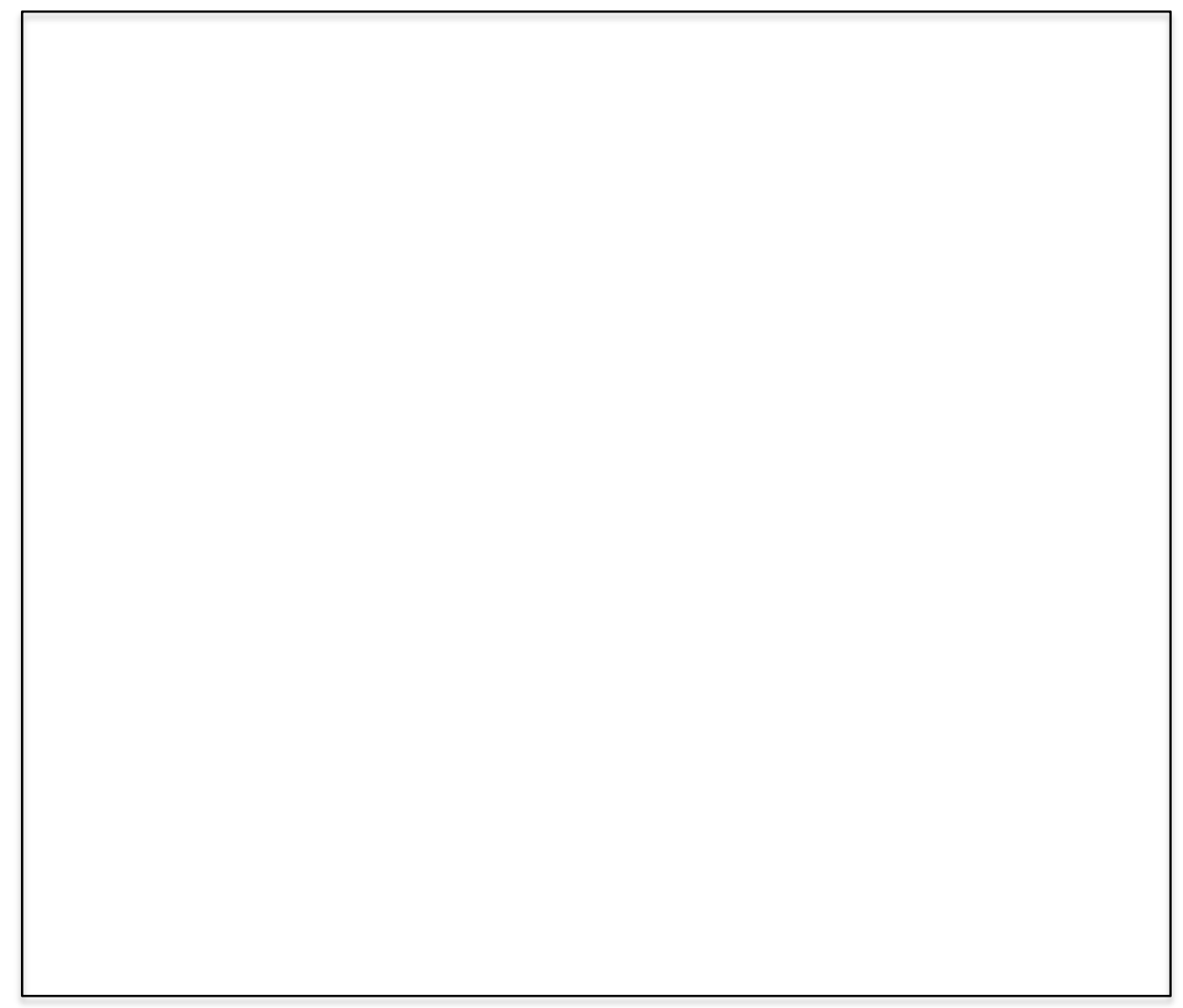

Figure 4.24. Scene twenty in the Historiscope, British Attack on Fort Moultrie. Chromolithographed on paper scroll. Reproduced digitally by Beinecke Rare Book and Manuscript Library, Yale University and sent per request of the author. 


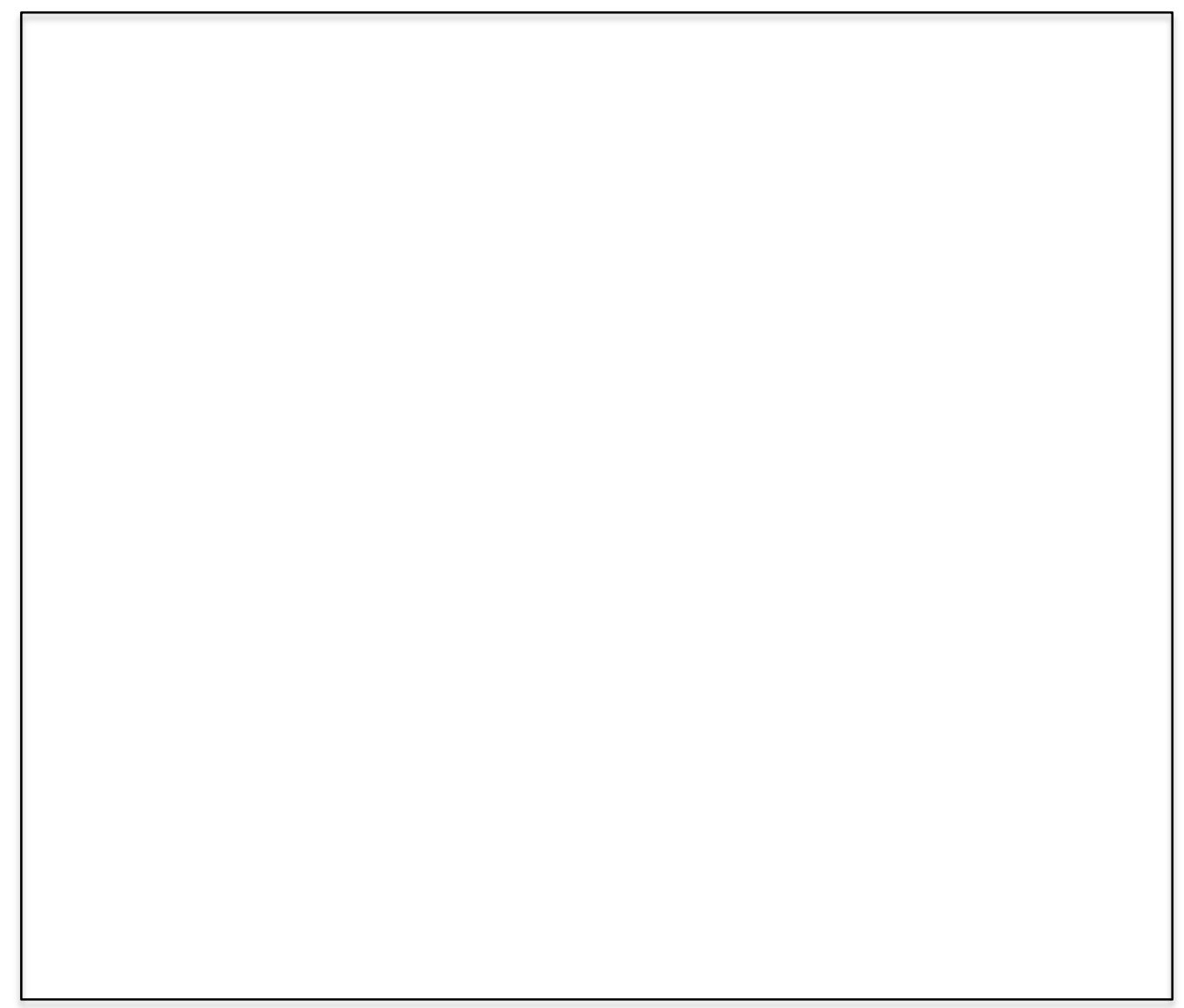

Figure 4.25. Scene twenty-one in the Historiscope, Independence Hall. Chromolithographed on paper scroll. Reproduced digitally by Beinecke Rare Book and Manuscript Library, Yale University and sent per request of the author. 


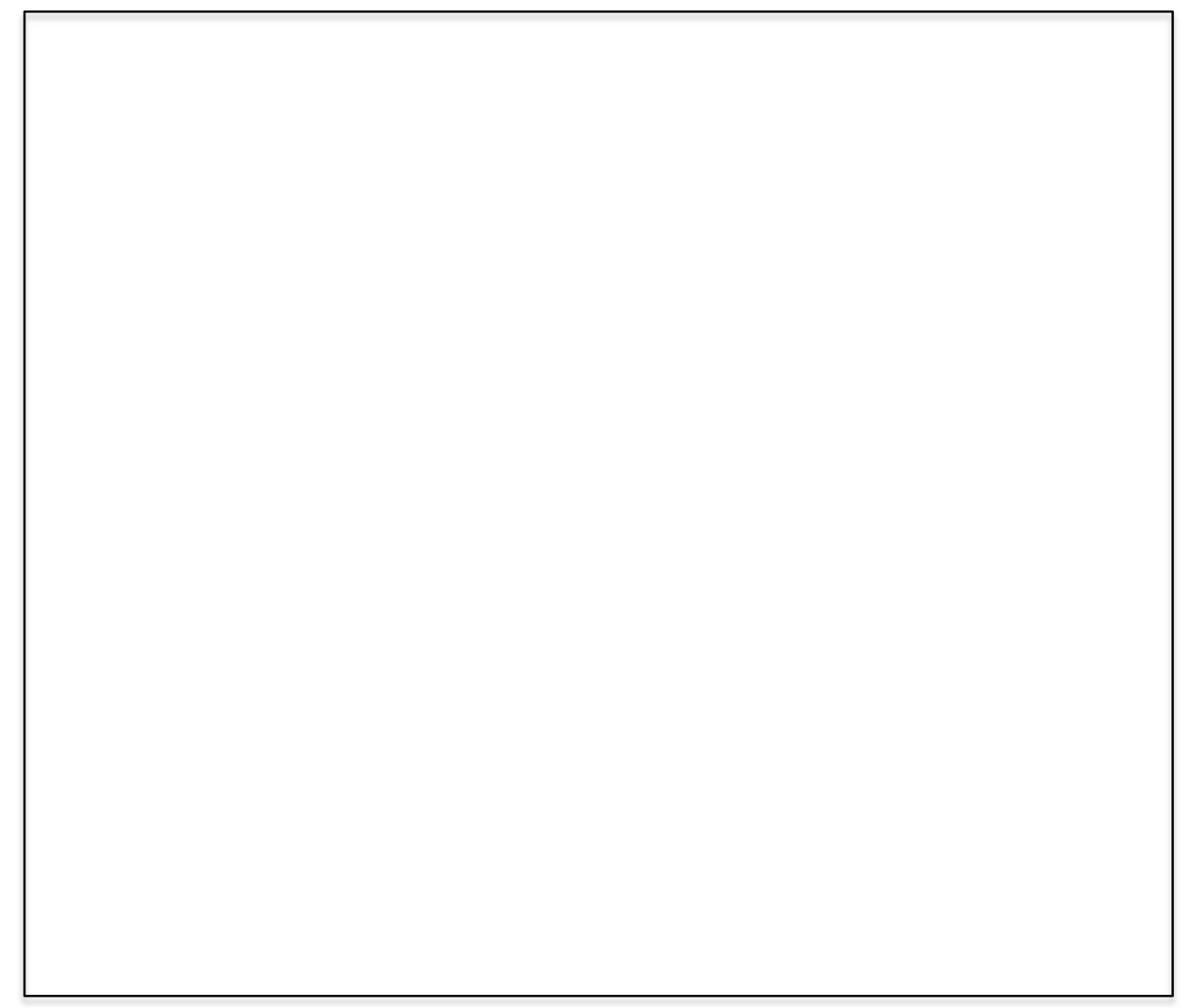

Figure 4.26. Scene twenty-two in the Historiscope, Winter at Valley Forge. Chromolithographed on paper scroll. Reproduced digitally by Beinecke Rare Book and Manuscript Library, Yale University and sent per request of the author. 


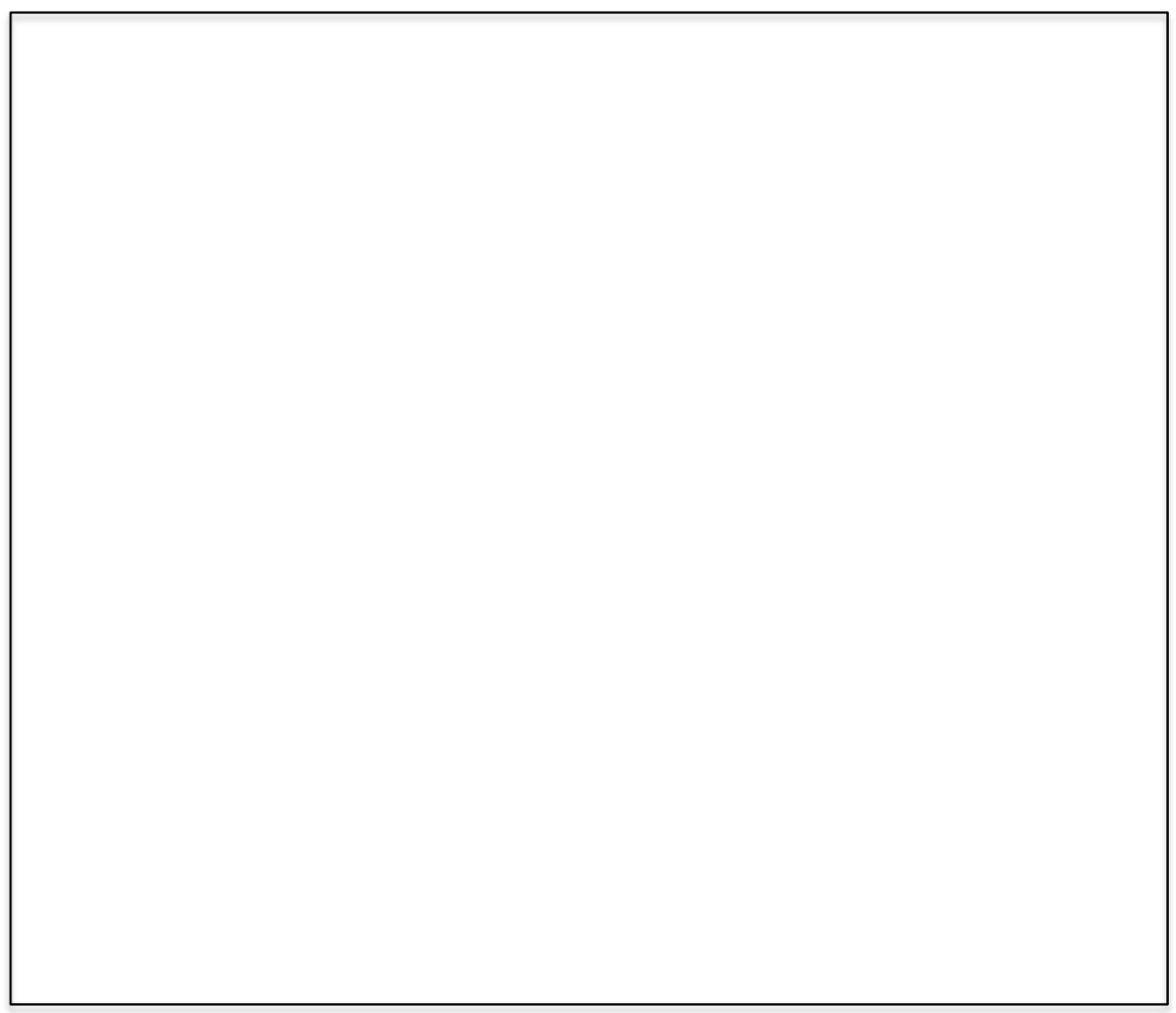

Figure 4.27. Scene twenty-three in the Historiscope, Putnam at Horseneck. Chromolithographed on paper scroll. Reproduced digitally by Beinecke Rare Book and Manuscript Library, Yale University and sent per request of the author. 


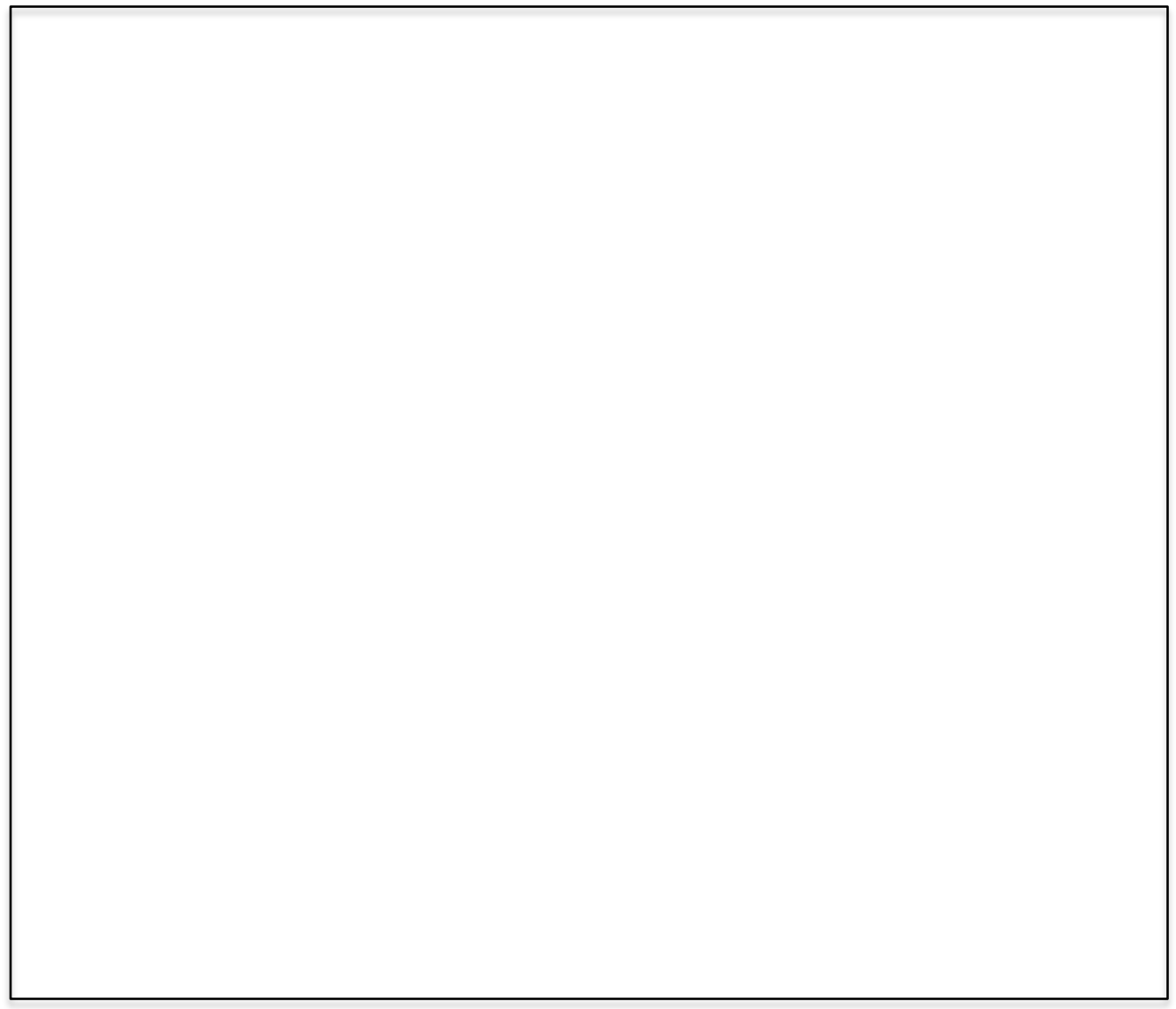

Figure 4.28. Scene twenty-four in the Historiscope, Arrest of Major André. Chromolithographed on paper scroll. Reproduced digitally by Beinecke Rare Book and Manuscript Library, Yale University and sent per request of the author. 


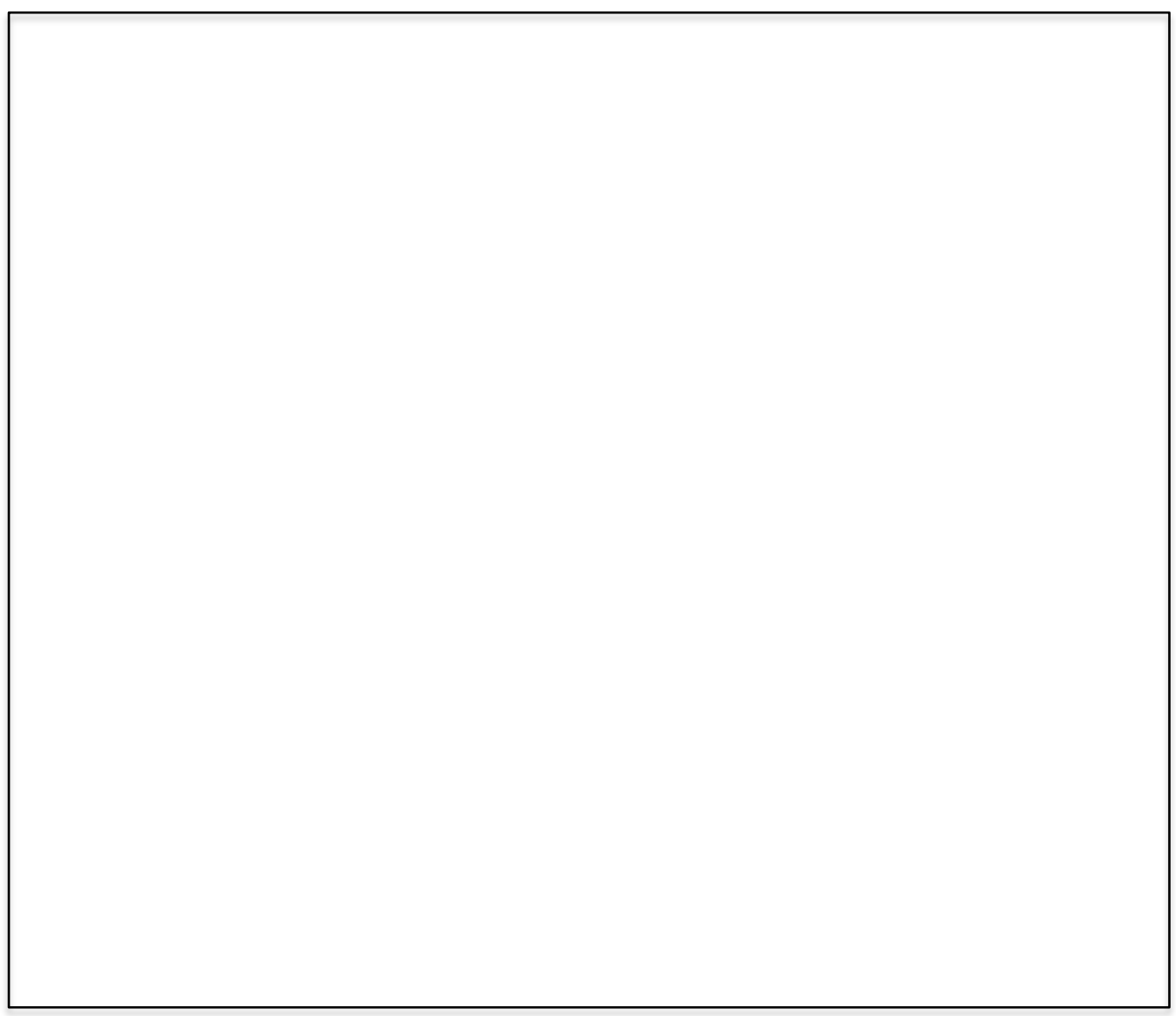

Figure 4.29. Scene twenty-five in the Historiscope, Lord Cornwallis surrendering to Washington. Chromolithographed on paper scroll. Reproduced digitally by Beinecke Rare Book and Manuscript Library, Yale University and sent per request of the author. 


\section{BIBLIOGRAPHY \\ PRIMARY SOURCES}

Abbott, John S. C. Ferdinand De Soto: The Discoverer of the Mississippi. New York: Dodd, Mead and Co., 1873.

. Advertisement for “Games for Soldiers.” Scientific American XI, no. 24

(Dec. 10, 1864): 383.

. “The 'Alabama,'” Harper's Weekly VIII, no. 394 (July 16, 1864): 450.

. "The Army of the Potomac - A Sharpshooter on Picket Duty - [From a

painting by W. Homer, Esq.]" Harper's Weekly VI, no. 307 (November 15, 1862): 724.

. "The Army Telegraph - Setting up the Wire during an Action." Harper's

Weekly VII, no. 317 (January 24, 1863): 53.

. "The Approach of the British Pirate 'Alabama.'” Harper's Weekly VII, no. 330 (April 25, 1863): 268.

Atherton, Jessie H. “Home As It Should Be." Godey's Lady's Book and Magazine LXXII (May 1866): 437-438.

. "The Attack on Fredericksburg - The Forlorn Hope Scaling the Hill." Harper's Weekly VI, no. 313 (December 27, 1862): 817.

Bancroft, George. History of the Colonization of the United States, Vol. I, $16^{\text {th }}$ ed. Boston: Little, Brown, and Co., 1858.

Bancroft, George. History of the United States, from the Discovery of the American Continent, Vol. IV, 14th ed. Boston: Little, Brown, and Co., 1858.

Barnard, George N. Photographic Views of Sherman's Campaign. New York: Dover Publications Inc., 1977. This is a re-publication of the work originally published in 1866 by George N. Barnard, New York. The New York Historical Society loaned their original edition for reproduction purposes.

"The Battle of Antietam - Carrying Off the Wounded After the Battle Sketched by Mr. A.R. Waud." Harper's Weekly VI, no. 302 (October 11, 1862): 649. 
. "The Battle of Bull Run, 2 PM July 21, 1861." Harper's Weekly V, no. 241

(August 10, 1861): 504-505.

Beecher, Catharine. A Treatise On Domestic Economy, 1841 edition. New York:

Schocken Books, 1977.

Beecher, Catharine, E. and Harriet Beecher Stowe. The American Woman's Home: or, Principals of Domestic Science; being a Guide to the Formation and Maintenance of Economical Healthful, Beautiful and Christian Homes. New York: J. B. Ford and Co., 1869.

. "The Beechers of To-Day," The Phrenological Journal and Life Illustrated LIL, no. 1 [whole no. 384] (January 1871): 5-12.

Bellew, Frank. The Art of Amusing: Being a Collection of Graceful Arts, Merry Games, Odd Tricks, Curious Puzzles, and New Charades. Together with suggestions for private theatricals, tableaux, and all sorts of parlor and family amusements. New York: Carleton, Publisher. London: S. Low, Son and Co., 1866.

. "The Berdan Sharpshooters at Weehawen." Harper's Weekly V, no.249 (October 5, 1861): 625.

. "The Bivouac Fire at the Outposts of Our Army of the Potomac." Harper's Weekly V, no. 249 (October 5, 1861): 632.

Blake, Rev. John Lauris. The Historical Reader, Designed for The Use of Schools and Families. Concord, N.H.: Horatio Hill and Co.; Boston: Richardson, Lord and Holbrook; New York: N. and J. White, and Collins and Hanney, 1825.

"Bombardment of Fort Sumter by the Batteries of the Confederate States, April 13, 1861." Harper's Weekly V, no. 226 (April 27, 1861): 264-265.

557.

. "Boys and Girls." Godey's Lady's Book and Magazine LXXIV (June 1867):

Bradley, Milton. "Games and Amusements As Benefits and Blessings in the Home." Good Housekeeping XXII (January 1896): 14-17.

. "The British Pirates 'Oreto' and 'Alabama.'” Harper's Weekly VI, no. 313 (December 27, 1862): 818.

Brown, William Wells. The Negro in the American Rebellion: His Heroism and his Fidelity. Boston: Lee and Shepard, 1867; New York: Kraus Reprint Co., 1969.

Campbell, L.J. A Concise School History of the United States based on Seavey's Goodrich's History. New York: Tainto Brothers, Merrill and Co., 1870. 
1870): 323 .

. "The Card House." Godey's Lady's Book and Magazine LXXX - 20 (April . “Check-Mate." Harper's Weekly IX, no. 440 (June 3, 1865): 337.

. “Childhood.” Godey's Lady's Book and Magazine LXXIII (July 1866): 69. . "Chromos." Godey's Lady's Book and Magazine LXXIX, no. 469 (July 1869):

83.

. “Colonel Berdan and His Sharpshooters." Harper's Weekly V, no. 243 (August 24, 1861): 540.

. “Colonel Ellsworth of the Fire Zouaves.” Harper's Weekly V, no. 228 (May 11, 1861): 289.

. "Contraband coming into camp in consequence of the Proclamation Drawn by Mr. A.R. Waud.” Harper's Weekly VII, no. 318 (January 31, 1863): 68.

24, 1864): 621.

. “Crow's-Nest Signal Station.” Harper's Weekly VIII, no. 404 (September

Downing, Andrew Jackson. The Architecture of Country Houses, Vol.II, originally printed in1850. New York: Da Capo Press Reprint Edition, 1968.

Downing, Andrew Jackson. Rural Essays. New York: Geo. A. Leavitt, 1869.

. "Entry of Major Anderson's Command into Fort Sumter on Christmas

Night, 1860." Harper's Weekly V, no. 211 (January 12, 1861): 25.

. 'The Ericsson Battery 'Monitor' Driving Off the 'Merrimac.' Harper's Weekly VI, no. 273 (March 22, 1862): 184-185.

67.

. "The Family Circle." Godey's Lady's Book and Magazine LXX (July 1865):

. "First Blood - The Sixth Massachusetts Regiment Fighting Their Way

Through Baltimore, April 19, 1861." Harper's Weekly V, no. 227 (May 4, 1861): 283.

“The Flag-Ship 'Hartford Attacked by the Ram 'Manassus' and a Fire-Raft in the Mississippi." Harper's Weekly VI, no. 285 (June 14, 1862): 369.

Franklin, Benjamin. Autobiography, ed. J.A. Leo Lemay and P.M. Zall. New York: Norton, 1986. 
Gardner, Alexander. Gardner's Photographic Sketch Book of the Civil War. New York: Dover Publications Inc., 1959. This is an unabridged and unaltered re-publication of the first edition published in 1866 entitled Gardner's Photographic Sketch Book of the War and printed in two volumes. The University of Pennsylvania Library loaned their original editions for reproduction purposes.

. “General Sherman's Victory - Rebel Prisoner's Being Conducted to Atlanta from Jonesborough.” Harper's Weekly VIII, no. 405 (October 1, 1864): 629.

. "General View of the Encampment of the Army of the Potomac at Harrison's Landing - Sketched by Mr. A.R. Waud. Harper's Weekly VI, no. 295 (August 23, 1862): 532.

. “General View of Fort Donelson - Sketched by Mr. A.L. Rawson. Harper's Weekly VI, no. 272 (March 15, 1862): 161.

Goodrich, Charles A. The Child's History of the United States. Revised by A.B. Berard. Philadelphia: Cowperthwait and Co., 1878.

Goodrich, Charles A. The Child's History of the United States Designed as a First Book of History for Schools. Illustrated by Numerous Anecdotes. Philadelphia: H. Cowperthwait and Co., 1869. Mary Chilton story is here on pp. 25-26

Goodrich, Charles A. History of the United States, for Schools. A History of the United States of America on a plan Adapted to the Capacity of Youth, and Designed To Aid the Memory by Systematic Arrangement and Interesting Associations. Boston: Hickling, Swan and Brewer, Cleveland: Ingham and Bragg, 1860.

Goodrich, Charles A. History of the United States of America; for Use of Schools; revised and brought down to the present time by William H. Seavey, principal of the Girl's High and Normal School. Boston: Brewer and Tileston, 1867.

Goodrich, Samuel G. The American Child's Pictorial History of the United States. Illustrated by sixty engravings. Philadelphia: E.H. Butler and Co., 1865.

Goodrich, Samuel G. The American Child's Pictorial History of the United States. Illustrated by sixty engravings. Philadelphia: E.H. Butler and Co., 1868.

Goodrich, Samuel G. The First Book of History. For Children and Youth. By the author of Peter Parley's Tales. With Sixty engravings and sixteen maps. Sixteenth edition. Boston: Charles J. Hendee, 1836.

Goodrich, Samuel G. The First Book of History, combined with Geography; Containing the History and Geography of the Western Hemisphere. For the Use of Schools. Revised 
and improved edition, with important additions. Boston: Jenks, Hickling, and Swan, 1852.

Goodrich, Samuel G. History of All Nations, From the Earliest Periods to the Present Time: or Universal History: in which the History of Every Nation, Ancient and Modern, is Separately Given. Illustrated by 70 Stylographic Maps, and 700 engravings. New York and Auburn: Miller, Orton and Mulligan, 1856.

Goodrich, Samuel G. Parley's Common School History Revised: A Pictorial History of the World, Ancient and Modern, For the Use of Schools. Philadelphia: E.H. Butler and Co., 1860.

Goodrich, Samuel G. Parley's First Book of History. The First Book of History, for Children and Youth. With sixty-eight engravings and sixteen maps. Fourth edition. Boston: Jenks, Palmer and Co., 1849.

Goodrich, Samuel G. Peter Parley's Spelling Book with engravings. Philadelphia: Henry F. Anners, New Orleans: Norman Steel and Co., Mobile: J.M. Sumwalt and Co., 1834.

Goodrich, Samuel G. ed. Peter Parley's Thousand and One Stories of Fact and Fancy, Wit and Humor, Rhyme, Reason, and Romance. Illustrated by Three Hundred Engravings. New York: Derby and Jackson, Cincinnati: H.W. Derby and Co., 1857.

Goodrich, Samuel G. A Pictorial History of the Western World. A Pictorial History of Americas Embracing both the Northern and Southern Portions of the New World. Illustrated with more than Three Hundred Engravings. Hartford: House and Brown, 1848.

Goodrich, S.G. A Pictorial History of the United States, with Notices of other Portions of America. New York: F.J. Huntington, and Mason \& Law, 1851.

Goodrich, Samuel G. A Pictorial History of the United States with Notices of Other Portions of America North and South. Philadelphia: E.H. Butler and Co. 1867.

Goodrich, Samuel G. The Tales of Peter Parley about America. Facsimile of 1828 edition. New York: Dover Publications, Inc., 1974.

Goodrich, Samuel G. The Tales of Peter Parley About America. With Engravings. Revised Edition. Philadelphia: Thomas, Cowperthwait and Co., 1845.

Guernsey, Alfred H. and Henry M. Alden. Harper's Pictorial History of the Civil War, facsimile copy. New York: The Fairfax Press, between 1970 and 1979 [originally published by Harper \& Brothers Part I in 1866 and Part 2 in 1868]. 
Hale, Sarah Josepha. "Editor's Table." Godey's Lady's Book and Magazine LXVI (February 1863): 199.

Hale, Sarah Josepha. "Editor's Table - The Angel of the House." Godey's Lady's Book and Magazine LXVI (June 1863): 578.

Hale, Sarah Josepha. “Editor's Table." Godey's Lady's Book and Magazine LXXV (October 1867): 354.

Hale, Sarah Josepha. "Editor's Table - How to Make a Happy Home." Godey's Lady's Book and Magazine LXVIII (January 1864): 198.

(October 1, 1864): 628.

. "The Halt - [Drawn by Thomas Nast.]" Harper's Weekly VIII, no. 405

. Harper's Weekly VIII, no. 382 (April 23, 1864): 257-272.

. "Harper's Weekly. Journal of Civilization. 1857-1864." The North

American Review 100, no. 207 (April 1865): 623-625.

Henty, G. A. True to the Old Flag: A Tale of the American War of Independence. New York: A. L. Burt, 1885.

275.

. “The Heroes Who First Fell.” Harper's Weekly V, no. 227 (May 4, 1861):

Hildreth, Richard. The History of the United States of America, in six volumes, Vol. I: Colonial, 1497-1688. New York: Harper and Brothers, Publishers, 1877.

Hildreth, Richard. The History of the United States of America, in six volumes, Vol. II: Colonial, 1663-1773. New York: Harper and Brothers, Publishers, 1877.

Hildreth, Richard. The History of the United States of America, in six volumes, Vol. III: Revolutionary, 1773-1789. New York: Harper and Brothers, Publishers, 1877.

H.T.M.C. “A Home Picture.” Godey's Lady's Book and Magazine LXXX (April 1870): 354.

. "The Irrepressible Conflict Again." Harper's Weekly VII, no. 321

(February 21, 1863): 114.

Irving, Washington. The Life and Voyages of Christopher Columbus, first published in 1828. New York: Thomas Y. Crowell and Co., no publication date - between 1900 and 1999. 
Laurie and Whittle. "Laurie and Whittle's new moral and entertaining game of The Mansion of Happiness." Victoria and Albert Museum. Accessed 2/25/2020.

http://collections.vam.ac.uk/item/026298/the-mansion-of-hppiness-laurie-boardgame/

Lilly, Lambert, Schoolmaster. The History of New England, Illustrated by Tales,

Sketches, and Anecdotes, with Numerous Engravings. Boston: Ticknor, Reed, and

Fields, 1833.

Lossing, Benson J. A Centennial Edition of the History of the United States: From the Discovery of America to the End of the First One Hundred Years of American Independence. Hartford: Thomas Belknap, 1876.

Lossing, Benson J. A Common School History of the United States: from the Earliest Period to the Present Time with over 200 engravings. New York: Mason Bros., 1868.

Lossing, Benson J. A Common School History of the United States; from the earliest period to the present time. New York: Sheldon and Company, 1870.

Lossing, Benson J. The Pictorial Field-book of the Revolution, or Illustrations, by Pen and Pencil, of the History, Biography, Scenery, Relics, and Traditions of the War of Independence, Vol. II . New York: Harper and Brothers, 1860.

Lossing, Benson J. Pictorial History of the Civil War in the United States of America. Vol. 1. Philadelphia: George W. Childs, 1866.

Lossing, Benson J. Pictorial History of the United States For Schools and Families. Illustrated by over 200 engravings. New York: Mason Brothers, San Francisco: H.H. Bancroft, and Co., 1858.

Lossing, Benson J. A Primary History of the United States. For Schools and Families. Illustrated with Numerous Engravings. A New Edition, Including a History of the Great Rebellion. New York: Mason Brothers, Boston: Mason and Hamlin, Philadelphia: J.B. Lippincott and Co., Cincinnati: Sargent, Wilson and Henkle, Chicago: George and C.W. Sherwood, 1867.

. "Lossing's Pictorial History of the Civil War." Godey's Lady's Book and Magazine LXXII (May 1866): 466.

. “The Lounger - Ellsworth.” Harper's Weekly V, no.232 (June 8, 1861): 354.

. "The Lounger - The Health of the Volunteer." Harper's Weekly V, no. 236

(July 6, 1861): 418.

"Major-General Ulysses S. Grant Before Vicksburg." Harper's Weekly VII, no. 337 (June 13, 1863): 376-377. 
. 'Marching On!' - The Fifty-fifth Massachusetts Colored Regiment Singing John Brown's March in the Streets of Charleston, February 21, 1865." Harper's Weekly IX, no. 429 (March 18, 1865): 165.

“Marching on!” Harper's Weekly IX, no. 429 (March 18, 1865): 172.

McElroy, John Harmon, ed. The Life and Voyages of Christopher Columbus, Volume XI of The Complete Works of Washington Irving. Boston: Twayne Publishers, 1981.

McGuffey, William H. McGuffey's Second Reader. The Eclectic Second Reader: Consisting of Progressive Lessons in Reading and Spelling; for the Younger Classes in Schools. With Engravings. Cincinnati: Winthrop B. Smith \& Co., 1844.

McGuffey, William H. McGuffey's Eclectic Second Reader: Containing Progressive Lessons in Reading and Spelling. Cincinnati: Winthrop B. Smith \& Co., 1853.

McGuffey, William H. McGuffey's Eclectic Third Reader: containing Elegant Extracts in Prose and Poetry, with Rules for Reading, and Exercises in Articulation, Defining, etc. Cincinnati: Winthrop B. Smith \& Co., 1844, 1853.

McGuffey, William H. McGuffey's Fourth Reader. The Eclectic Fourth Reader, containing Elegant Extracts in Prose and Poetry, from the Best American and English Writers, with Copious Rules for Reading, and Directions for Avoiding Common Errors. Cincinnati: Winthrop B. Smith \& Co., 1844.

McGuffey, William H. McGuffey's Eclectic Fourth Reader: containing Elegant Extracts in Prose and Poetry, with Rules for Reading, and Exercises in Articulation, Defining, etc. Cincinnati: Sargent, Wilson and Hinkle, New York: Clark \& Maynard, 1853.

McGuffey, William H. McGuffey's New Fifth Eclectic Reader: Selected and Original Exercises for Schools. Cincinnati and New York: Van Antwerp, Bragg and Co., 1857.

McGuffey, William H. McGuffey's Fifth Eclectic Reader: 1879 ed. / with a foreword by Henry Steele Commager. New York: New American Library, 1962.

Milton Bradley \& Company. "The Checkered Game of Life - Rules of the Game." In The Checkered Game of Life. Springfield, Massachusetts: Milton Bradley \& Co., 1860.

Milton Bradley \& Company. "Directions to the Proprietor of the Historiscope." In The Historiscope A Panorama and History of America. Springfield, Massachusetts: Milton Bradley \& Co., 1868.

Milton Bradley \& Company. "Directions to the Proprietor of the Myriopticon." In The Myriopticon A Historical Panorama of the Rebellion. Springfield, Massachusetts: Milton Bradley \& Co., 1866. 
Milton Bradley \& Company. "Historiscope Lecture." In The Historiscope A Panorama and History of America. Springfield, Massachusetts: Milton Bradley \& Co., 1868.

Milton Bradley \& Company. "Myriopticon Lecture." In The Myriopticon A Historical Panorama of the Rebellion. Springfield, Massachusetts: Milton Bradley \& Co., 1866.

Milton Bradley \& Company. Work and Play Annual of Home Amusements and Social Sports. Springfield, Massachusetts: Milton Bradley \& Co., 1871-72. 1864): 306.

“Mississippi Valley Sanitary Fair." Harper's Weekly VIII, no. 385 (May 14, . "A Mother's Teaching - (taken from Fraser's Magazine)." Godey's Lady's Book and Magazine LXXII (January 1866): 91. 369. ."The Murder of Ellsworth." Harper's Weekly V, no. 233 (June 15, 1861):

Neff, Jacob K. Thrilling Incidents in American History: Comprising the Most Striking and Remarkable Events of the Revolution, the French War, the Tripolitan War, the Indian Wars, the Second War with Great Britain, and the Mexican War. Philadelphia: John E. Potter and Co., 1866.

https://books.google.com/books?id=6GhHAQAAMAAJ\&vq=the $\% 20$ battle $\% 20$ of $\% 2$ Ofort $\% 20$ moultrie\&pg=PA163\# $\mathrm{v}=$ onepage $\& \mathrm{q}=$ the $\% 20$ battle $\% 20$ of $\% 20$ fort $\% 20 \mathrm{mo}$ ultrie\&f=false Accessed August 23, 2018

18. . “Negro Emancipation," Harper’s Weekly VII, no. 315 (January 10, 1863): " "On the Mississippi - Porter's Mortar in Action - sketched by Mr. Theodore R. Davis." Harper's Weekly VI, no. 294 (August 16, 1862): 520. ."Our Artists During the War." Harper's Weekly IX, no. 440 (June 3, 1865): 339. 322. . “To Our Southern Readers." Harper's Weekly V, no. 230 (May 25, 1861):

Parley, Peter. The Tales of Peter Parley about America. Facsimile of the 1828 edition with an introduction by Barrows Mussey. New York: Dover Publications, Inc., 1974.

Pierpont, John. The National Reader, A Selection of Exercises in Reading and Speaking, Designed to Fill the Same Place in the Schools of the United States, that is held in those of Great Britain. Boston: Hilliard, Gray, Little, and Wilkins, and Richardson and Lord, 1828. 
. "A Political Catechism for Children." Harper's Weekly V, no. 245

(September 7, 1861): 562.

Pollard, Edward A. Southern History of the War: The First Year of the War. New York: B. Richardson, 1865.

Pollard, Edward A. Southern History of the War: The Second Year of the War. New York: Charles B. Richardson, 1864.

Pollard, Edward A. Southern History of the War: The Third Year of the War. New York: Charles B. Richardson, 1865.

Pollard, Edward A. Southern History of the War: The Last Year of the War. New York: Charles B. Richardson, 1866.

. 'The Pirate 'Alabama,' Alias '290,' Certified to be Correct by Captain Hagar of the 'Brilliant.'” Harper's Weekly VI, no. 305 (November 1, 1862): 689.

“Remember Fort Sumter!" Civil War envelope (1861). Library of Congress, accessed March 17, 2019. https://www.loc.gov/item/2011648573/

. "Return of a Foraging Party to Philippi, Virginia." Harper's Weekly V, no. 242 (August 17, 1861): 518.

Sanders, Charles W. The School Reader, third book: containing progressive lessons in reading, exercises in articulation and inflection, definitions, etc. New York and Chicago: Ivison, Blakeman, Taylor and Co., 1860.

. "Scenes on the Battlefield of Antietam - From Photographs by Mr. M.B.

Brady - The Stone Bridge." Harper's Weekly VI, no. 303 (October 18, 1862): 664-665.

Sherwood, John D. The Comic History of the United States, from a period prior to the discovery of America to times long subsequent to the present. Boston: Fields, Osgood, \& Co., 1870.

. "The Sinking of the 'Alabama' off Cherbourg June 19, 1864." Harper's Weekly VIII, no. 395 (July 23, 1864): 465.

Smith, Mrs. Caroline L. (Aunt Carrie). The American Home Book of In-Door Games, Amusements, and Occupations. Boston: Lee and Shepard, Publishers, 1872.

Stowe, Harriet Beecher [under the pseudonym Christopher Crowfield]. House and Home Papers. Boston: Ticknor and Fields, 1865.

Tower, James E. ed. Springfield Present and Prospective. The City of Homes: The Sources of Its Charm, Its Advantages, Achievements and Possibilities, Portrayed in 
Word and Picture. Text by Eugene C. Gardner, William Orr, J. Frank Drake, Charles Goodrich Whiting, Judge A. M. Copeland and others. Drawings by James Hall and George Clarence Gardner. Springfield, Mass.: Pond and Campbell, 1905.

W. \& S. B. Ives. "The Mansion of Happiness - Explanation of the Game and Rules of the Game." The Mansion of Happiness. Salem, Massachusetts: W. \& S. B. Ives, 1843.

Webster, Daniel. An Address Delivered at the Laying of the Cornerstone of the Bunker Hill Monument. $4^{\text {th }}$ edition. Boston: Cummings, Hilliard, and Co., 1825.

Webster, Daniel. Address, Delivered at Bunker Hill, June 17, 1843, on the Completion of the Monument. Boston: Press of T.R. Marvin, 1843.

Webster, Daniel. Discourse, Delivered at Plymouth, December 22, 1820. In Commemoration of the First Settlement of New England. $2^{\text {nd }}$ edition. Boston: Wells and Lilly, 1821. https://babel.haithitrust.org/cgi/pt?id=mov.010506634830;view=1up;seq=5

Webster, Noah. An American Selection of Lessons in Reading and Speaking. Calculated to Improve the Minds and Refine the Taste of Youth. To Which are Prefixed Rules of Elocution, and Directions for Expressing the Principal Passions of the Mind. Being The Third Part of a Grammatical Institute of the English Language, 10 th edition. Hartford: Hudson and Goodwin, 1796 (1811?).

Webster, Noah. An American Selection of Lessons in Reading and Speaking. Calculated to Improve the Minds and Refine the Taste of Youth. To Which are Prefixed Rules of Elocution, and Directions for Expressing the Principal Passions of the Mind. Being The Third Part of a Grammatical Institute of the English Language, 14th edition. Hartford: Hudson and Goodwin, 1800.

Webster, Noah. Elements of Useful Knowledge. Containing a Historical and Geographical Account of the United States; For the Use of Schools. Volume I. New London: Printed for O.D. Cooke, by Ebenezer P. Cady, 1807.

Webster, Noah. Elements of Useful Knowledge. Containing a Historical and Geographical Account of the United States; For the Use of Schools. Volume II. New Haven: Sidney's Press for Increase Cooke and Co., 1806.

Webster, Noah. History of the United States To Which is Prefixed A Brief Historical Account of Our [English] Ancestors, From The Dispersion at Babel, To Their Migration to America And of The Conquest of South America, By The Spaniards. New Haven: Durrie and Peck; Louisville, KY: Wilcox, Dickerman and Co., 1832.

Webster, Noah. Letters to a Young Gentleman Commencing His Education: To Which is Subjoined A Brief History of the United States. New Haven: Howe and Spalding, 1823. 
Weems, Parson. A History of the Life and Death, Virtues and Exploits of General George Washington. ?: Grosset and Dunlap, ? (copyright in 1927 by Macy-Masius: Publishers; originally published in 1800)

Willard, Emma. History of the United States, or Republic of America: with a chronological table and a series of progressive maps. New York: A.S. Barnes \& Burr, 1864.

"Willard's Hotel, Washington, Saved by the New York Fire Zouaves."

Harper's Weekly V, no. 230 (May 25, 1861): 230.

Williams, Henry T. and Mrs. C. S. Jones. Beautiful Homes. Or, Hints in House Furnishing. New York: Henry T. Williams, Publisher, 1878.

. “Woman's Piety." Godey's Lady's Book and Magazine LXXII (May 1866):

517. 


\section{BIBLIOGRAPHY \\ SECONDARY SOURCES}

Adams, David Wallace and Victor Edmonds. "Making Your Move: The Educational Significance of the American Board Game, 1832 to 1904." History of Education Quarterly 17, no. 4 (Winter 1977): 359-383.

Adams, George Worthington. Doctors in Blue: The Medical History of the Union Army in the Civil War. New York: Henry Schuman, 1952.

. American Dictionary of Printing and Bookmaking, containing a history of these arts in Europe and America, with definitions of technical terms and biographical sketches. New York: Howard Lockwood \& Co., 1894.

Ames, Kenneth L. Death in the Dining Room and Other Tales of Victorian Culture. Philadelphia: Temple University Press, 1992.

Anderson, Benedict. Imagined Communities: Reflections on the Origin and Spread of Nationalism, revised edition. London and New York: Verso, 2006.

Anderson, Patricia. The Printed Image and the Transformation of Popular Culture, 1790-1860. Oxford and New York: Oxford University Press, 1991.

Architect of the Capitol. "Historic Rotunda Paintings." Accessed February 1, 2020. aoc.gov/art/historic-rotunda-paintings

Axelrod, Alan D., ed. The Colonial Revival in America. New York: Norton, published for The Henry Francis du Pont Winterthur Museum, 1985

Ayres, William, ed. Picturing History: American Painting 1770-1930 [exh. cat.]. New York: Rizzoli, 1993.

Bailey, Ronald H. and the editors of Time-Life Books, Inc. The Bloodiest Day: The Battle of Antietam. Alexandria, VA: Time-Life Books, 1984.

Bank, Rosemarie K. Theatre Culture in America, 1825-1860. Cambridge, New York, Melbourne: Cambridge University Press, 1997.

Barber, Marshall A. The Schoolhouse at Prairie View. Lawrence: University of Kansas Press, 1953.

Barnard, F.M.. "National Culture and Political Legitimacy: Herder and Rousseau." Journal of the History of Ideas 44, no. 2 (Apr. - June, 1983): 231-253. 
Berger, John, Sven Blomberg, Chris Fox, Michael Dibb, Richard Hollis. Ways of Seeing. London: British Broadcasting Corporation and Penguin Books, 1972.

Berger, Martin. Sight Unseen: Whiteness and American Visual Culture. Berkeley, LA, London: University of California Press, 2005.

Bloch, Ruth H. Visionary Republic: Millennial Themes in American thought, 17561800. Cambridge and New York: Cambridge University Press, 1985.

Bode, Carl. The American Lyceum: Town Meeting of the Mind. New York: Oxford University Press, 1956.

Boime, Albert. The Art of Exclusion: Representing Blacks in the Nineteenth Century. Washington and London: Smithsonian Institution Press, 1990.

Broadwater, Robert P. Civil War Special Forces: The Elite and Distinct Fighting Units of the Union and Confederate Armies. Santa Barbara, Denver, London: Praeger, 2014.

Brooks, Stewart. Civil War Medicine. Springfield, Illinois: Charles C. Thomas, 1966.

Brownlee, Peter John, Sarah Burns, Diane Dillon, Daniel Greene, Scott Manning Stevens. Home Front: Daily Life in the Civil War North [exh. cat.]. Chicago and London: The University of Chicago Press, 2013.

Bryden, Inga and Janet Floyd, eds. Domestic Space: Reading the nineteenth-century interior. Manchester and New York: Manchester University Press, 1999.

Burnham, Patricia M. and Lucretia Hoover Giese, eds. Redefining American History Painting. Cambridge and New York: Cambridge University Press, 1995.

Burns, Rex. Success in America: The Yeoman Dream and the Industrial Revolution. Amherst: University of Massachusetts Press, 1976.

Burns, Sarah and John Davis. American Art to 1900: A Documentary History. Berkeley, LA, London: University of California Press, 2009.

Calhoun, Arthur W. A Social History of the American Family from Colonial Times to the Present, Vol. II from Independence through the Civil War. Cleveland; The Arthur H. Clark Company, 1918.

Calhoun, Arthur W. A Social History of the American Family from Colonial Times to the Present, Vol. III since the Civil War. Cleveland; The Arthur H. Clark Company, 1919.

Calo, Mary Ann. Critical Issues in American Art: A Book of Readings. Boulder, Colorado: Westview Press, 1998. 
Calvert, Karin. Children in the House: The Material Culture of Early Childhood, 16001900. Boston: Northeastern University Press, 1992.

Carley, Rachel. The Visual Dictionary of American Domestic Architecture. New York: Henry Holt and Company, 1994.

Carp, Benjamin L. Defiance of the Patriots: the Boston Tea Party and the Making of America. New Haven and London: Yale University Press, 2010.

Carpenter, Charles. History of American Schoolbooks. Philadelphia: University of Pennsylvania Press, 1963.

Clark, Clifford Edward Jr. The American Family Home, 1800-1960. Chapel Hill and London: The University of North Carolina Press, 1986.

Corn, Wanda. "Coming of Age: Historical Scholarship in American Art." The Art Bulletin 70, no. 2 (June 1988): 188-207.

Crary, Jonathan. Techniques of the Observer: On Vision and Modernity in the Nineteenth Century. Cambridge, Mass. and London: MIT Press, 1990.

Cremin, Lawrence. American Education: The National Experience, 1783 - 1876. New York: Harper and Row, 1980.

Cross, Gary. Kids' Stuff: Toys and the Changing World of American Childhood. Cambridge, MA and London: Harvard University Press, 1997.

Dahl, Curtis. "Mark Twain and the Moving Panoramas," American Quarterly 13, no. 1 (Spring 1961): 20-32.

Dawson, Melanie. Laboring to Play: Home Entertainment and the Spectacle of MiddleClass Cultural Life, 1850-1920. Tuscaloosa: The University of Alabama Press, 2005.

Deetz, James. In Small Things Forgotten: The Archaeology of Early American Life. New York: Anchor Books, 1977.

Delgado, Alan. Victorian Entertainment. New York: American Heritage Press, 1971.

Dorman, James H., Jr. Theater in the Antebellum South 1815-1861. Chapel Hill: The University of North Carolina Press, 1967.

Duncan, Carol. “The Art Museum as Ritual.” In Civilizing Ritual: Inside Public Art Museums, 7-20. London and New York: Routledge, 1995. 
Earle, Edward W. Points of View: The Stereograph in America - A Cultural History. Rochester, New York: The Visual Studies Workshop Press, 1979.

Edwards, Phil. "Why the game of Life used to have poverty, suicide, and ruin." Vox. Updated January 13, 2020. Vox.com/2015/1/28/7924487/game-of-life-history

Elson, Ruth Miller. Guardians of Tradition: American Schoolbooks of the Nineteenth Century. Lincoln: University of Nebraska Press, 1964.

Exman, Eugene. The House of Harper: One Hundred and Fifty Years of Publishing. New York, Evanston and London: Harper and Row Publishers, 1967.

Ferber, Linda S. "Albert Bierstadt: The History of a Reputation." In Albert Bierstadt: Art and Enterprise edited by Nancy K. Anderson and Linda S. Ferber [exh. cat.]. New York: Hudson Hills Press in assoc. with the Brooklyn Museum, 1990.

Finlay, Nancy, ed. Picturing Victorian America: Prints by the Kellogg Brothers of Hartford, Connecticut, 1830-1880. [exh. cat.] Hartford, CT: Connecticut Historical Society, 2009.

Foster, Gaines M. Ghosts of the Confederacy: Defeat, the Lost Cause, and the Emergence of the New South 1865 to 1913. New York, Oxford: Oxford University Press, 1987.

Foy, Jessica H. and Thomas J. Schlereth, eds. American Home Life, 1880-1930. Knoxville: The University of Tennessee Press, 1992.

Frassanito, William A. Antietam: the Photographic Legacy of America's Bloodiest Day. New York: Charles Scribner's Sons, 1978.

Freeman, G. L. Currier and Ives Pictorial History of American Battle Scenes. Watkins Glen, N.Y.: Century House, 1961.

Freeman, Ruth and Larry. Cavalcade of Toys. New York: Century House, 1942.

Freeman, Ruth S. Yesterday's School Books: A Looking Glass for Teachers of Today. Watkins Glen, NY: Century House, 1960.

Fryd, Vivian Green. "Rereading the Indian in Benjamin West's Death of General Wolfe" American Art 9 (Spring 1995): 73-85.

Funding Universe. "Milton Bradley Company History." Accessed 2/24/2020. http://www.fundinguniverse.com/company-histories/milton-bradley-companyhistory/ 
Gallaher, Gary W. and Alan T. Nolan, eds. The Myth of the Lost Cause and Civil War History. Bloomington and Indianapolis: Indiana University Press, 2000.

Garrett, Elisabeth Donaghy. At Home: The American Family 1750-1870. New York: Harry N. Abrams, Inc., 1990.

Gernsheim, Helmut and Alison. L.J.M. Daguerre: The History of the Diorama and the Dagurerreotype. New York: Dover Publications, Inc., 1968.

Giese, Lucretia Hoover and Roy Perkinson. "A Newly Discovered Drawing of Sharpshooters by Winslow Homer: Experience, Image and Memory." Winterthur Portfolio 45, no. 1 (Spring 2011): 61-90.

Gitelman, Lisa and Geoffrey B. Pingree. New Media, 1740-1915. Cambridge, Mass. and London: MIT Press, 2003.

Godbey, Emily. 'Terrible Fascination:' Civil War Stereographs of the Dead." History of Photography 36, no. 3 (July 9, 2012): 268.

Goodman, Ruth. How to Be a Victorian: A Dawn-to-Dusk Guide to Victorian Life. New York and London: Liveright Publishing Corporation, 2013.

Greenfeld, Liah. Nationalism: Five Roads to Modernity. Cambridge, MA and London: Harvard University Press, 1992.

Grier, Katherine C. Culture and Comfort: Parlor Making and Middle-Class Identity, 1850-1930. Washington and London: Smithsonian Institution Press, 1988.

Griffiths, Alison. Shivers Down Your Spine: Cinema, Museums, and the Immersive View. New York: Columbia University Press, 2008.

Grover, Kathryn, ed. Hard at Play: Leisure in America, 1840-1940. Rochester, New York: The Strong Museum, 1992.

Habermas, Jurgen. The Structural Transformation of the Public Sphere: An Inquiry into a Category of Bourgeois Society. Translated by Thomas Burger with the assistance of Frederick Lawrence. Cambridge, Massachusetts: MIT Press, 1989. This work originally appeared in German under the title Strukturwandel der Öffentlicheit in 1962.

Halttunen, Karen. Confidence Men and Painted Women: A Study of Middle-Class Culture in America, 1830-1870. New Haven and London: Yale University Press, 1982.

Handlin, David P. The American Home: Architecture and Society, 1815-1915. Boston, Toronto: Little, Brown and Company, 1979. 
Handy, Robert T. A Christian America: Protestant Hopes and Historical Realities, $2^{\text {nd }}$ ed. New York and Oxford: Oxford University Press, 1984.

Heidler, David S. and Jeanne T. Heidler, eds. Encyclopedia of the American Civil War. Santa Barbara, California: ABC-CLIO, 2000.

Hess, Earl J. Liberty, Virtue, and Progress: Northerners and Their War for the Union. New York and London: New York University Press, 1988.

Hobsbawm, E. J. Nations and Nationalism Since 1780: Programme, Myth, Reality. Cambridge: Cambridge University Press, 1990.

Hofer, Margaret K. The Games We Played: The Golden Age of Board and Table Games. [exh. cat.] New York Historical Society's Liman Collection. New York: Princeton Architectural Press, 2003.

Holzer, Harold, ed. Prang's Civil War Pictures: The Complete Battle Chromos of Louis Prang. New York: Fordham University Press, 2001.

Howat, John K. Frederic Church. New Haven and London: Yale University Press, 2005.

Huber, Richard M. The American Idea of Success. New York: McGraw-Hill Book Company, 1971.

Huhtamo, Erkki. Illusions in Motion: Media Archaeology of Moving Panorama and Related Spectacles. Cambridge, Massachusetts, London: The MIT Press, 2013.

Hyde, Anne F. "Cultural Filters: The Significance of Perception in the History of the American West.” The Western Historical Quarterly, 24, No. 3 (1993), 351-374.

Jellison, Katherine. It's Our Day: America's Love Affair with the White Wedding, 19452005. Lawrence, Kansas: University of Kansas Press, 2008.

Jensen, Jennifer. "Teaching Success Through Play: American Board and Table Games 1840-1900. Antiques 160, no. 6 (December 2001): 812-819.

Johns, Elizabeth. American Genre Painting: The Politics of Everyday Life. New Haven and London: Yale University Press, 1991.

Johnson, Clifton. Old-Time Schools and School-Books, first published in 1904. Republished by Detroit: Omnigraphics, 1999.

Johnston, Patricia, ed. Seeing High and Low: Representing Social Conflict in American Visual Culture. Berkeley, Los Angeles, London: University of California Press, 2006. 
Joyce, Barry. The First U.S. History Textbooks: Constructing and Disseminating the American Tale in the Nineteenth Century. Lanham, Boulder, New York, London: Lexington Books, 2015.

Koja, Stephan, ed. America: The New World in Nineteenth-Century Painting. Munich, Germany: Prestel Verlag, 1999.

Koller, Gabriele, ed. The Panorama in the Old World and the New. Amberg, Germany: Büro Wilhelm, 2010.

Kopytoff, Igor. "The Cultural Biography of Things: Commoditization as Process." In The Social Life of Things: Commodities in Cultural Perspective, edited by Arjun Appadurai, 64-91. Cambridge: Cambridge University Press, 1986.

Kraus, Michael and Davis D. Joyce. The Writing of American History. Norman, Oklahoma: University of Oklahoma Press, 1985.

Lankford, Nelson. Richmond Burning: The Last Days of the Confederate Capital. New York: Viking, 2002.

Leavitt, Sarah A. From Catharine Beecher to Martha Stewart: A Cultural History of Domestic Advice. Chapel Hill and London: The University of North Carolina Press, 2002.

LeBeau, Brian F. Currier and Ives: America Imagined. Washington and London: Smithsonian Press, 2001.

Lepore, Jill. Mansions of Happiness: A History of Life and Death. New York: Alfred A. Knopf, 2012.

Levine, Lawrence W. and Robert Middlekauff, eds. The National Temper: Readings in American History. New York: Harcourt, Brace and World, Inc. 1968.

Liftig, Kevin. "The Evolution of Copyright Law in the Arts." University of Connecticut, Honors Scholar Thesis, 2009.

https://opencommons.uconn.edu/cgi/viewcontent.cgi?article=1114\&context=srho nors_theses

Lindberg, Stanley W. The Annotated McGuffey: Selections from the McGuffey Eclectic Readers 1836-1920. New York: Van Nostrand Reinhold Company, 1976.

Luarca-Shoaf, Nenette, Claire Barry, Nancy Heugh, Elizabeth Mankin Kornhauser, Dorothy Mahon, Andrew J. Walker, and Janeen Turk. [Exh. Cat.] Navigating the West: George Caleb Bingham and the River. Amon Carter Museum of American Art and St. Louis Art Museum. Distributed by Yale University Press: New Haven and London, 2014. 
Lubin, David M. Picturing a Nation: Art and Social Change in Nineteenth-Century America. New Haven and London: Yale University Press, 1994.

Lynes, Russell. The Domesticated Americans. New York, Evanston, and London: Harper and Row, Publishers, 1963.

Marten, James. "History in a Box: Milton Bradley's Myriopticon." The Journal of the History of Childhood and Youth 2,no. 1 (Winter 2009): 3-7.

Marten, James. The Children's Civil War. Chapel Hill and London: The University of North Carolina Press, 1998.

Martin, Edgar W. The Standard of Living in 1860. Chicago: The University of Chicago Press, 1942.

Marty, Martin E. Righteous Empire: The Protestant Experience in America. New York: The Dial Press, 1970.

Marzio, Peter. The Democratic Art: Pictures for a 19th-Century America, Chromolithography 1840-1900. Boston: D.R. Godine, 1979.

McClintock, Inez and Marshall. Toys in America. Washington, D.C.: Public Affairs Press, 1961.

McClinton, Katharine Morrison. Antiques of American Childhood. New York: Clarkson N. Potter Inc., 1970.

McClinton, Katharine Morrison. The Chromolithographs of Louis Prang. New York: Clarkson N. Potter, Inc., 1973.

McConachie, Bruce A. Melodramatic Formations: American Theatre and Society, 1820-1870. Iowa City: University of Iowa Press, 1992.

McDannell, Colleen. The Christian Home in Victorian America, 1840-1900. Bloomington: Indiana Univ. Press, 1986.

McDannell, Colleen. Material Christianity: Religion and Popular Culture in America. New Haven and London: Yale University Press, 1995.

McDermott, John Francis. The Lost Panoramas of the Mississippi. Chicago: University of Chicago Press, 1958.

McMurry, Sally. "City Parlor, Country Sitting Room: Rural Vernacular Design and the American Parlor, 1840-1900." Winterthur Portfolio 20, no. 4 (Winter, 1985): 261280. 
Menand, Louis. The Metaphysical Club. New York: Farrar, Straus and Giroux, 2001.

Mergen, Bernard. "The Discovery of Children's Play." American Quarterly 27, no. 4 (October, 1975): 399-420.

Miller, Angela. "Everywhere and Nowhere: The Making of the National Landscape." American Literary History, 4, No. 2 (Summer, 1992), 207-229.

Miller, Angela. "'The Soil of an Unknown America': New World Lost Empires and the Debate over Cultural Origins." American Art, 8, No 3/4 (Summer - Autumn), 8-27.

Miller, Angela L., Janet C. Berlo, Bryan J. Wolf, and Jennifer L. Roberts. American Encounters: Art, History and Cultural Identity. Upper Saddle River, NJ.: Prentice Hall, 2008.

Miller, David C., ed. American Iconology: New Approaches in $19^{\text {th }}$ Century Art and Literature. New Haven and London: Yale University Press, 1993.

Miller, Tice L. Entertaining the Nation: American Drama in the Eighteenth and Nineteenth Centuries. Carbondale: Southern Illinois University Press, 2007.

Monaghan, E. Jennifer. A Common Heritage: Noah Webster's Blue-Back Speller. Hamden, CT: Archon Books, 1983.

Morgan, David. The Forge of Vision: A Visual History of Modern Christianity. Oakland, California: University of California Press, 2015.

Morgan, David. Protestants and Pictures: Religion, Visual Culture, and the Age of American Mass Production. New York and Oxford: Oxford University Press, 1999.

Morison, Samuel Eliot. Admiral of the Ocean Sea: A Life of Christopher Columbus. Boston: Northeastern University Press, 1983.

Motz, Marilyn Ferris and Pat Browne, eds. Making the American Home: Middle-class Women and Domestic Material Culture 1840-1940. Bowling Green, Ohio: Bowling Green State University Popular Press, 1988.

Murray, H.J.R. A History of Board-Games Other Than Chess. Oxford: Clarendon Press, 1952.

Musser, Charles. The Emergence of Cinema: The American Screen to 1907. New York: Charles Scribner's and Sons, 1990.

Nabakov, Peter and Robert Easton. Native American Architecture. New York and Oxford: Oxford University Press, 1989. 
Neely, Mark E. Jr. and Harold Holzer. The Union Image: Popular Prints of the Civil War North. Chapel Hill and London: The University of North Carolina Press, 2000.

New England Historical Society. "Milton Bradley and Life's Checkered Past." Accessed 2/24/2020.

newenglandhistoricalsociety.com/Milton-bradley-lifes-checkered-past/

New York Historical Society. "The Games We Played: American Board and Table Games from the Liman Collection Gift, April 2 - January 5, 2003. Accessed 2/24/2020. nyhistory.org/exhibitions/the-games-we-played\#

Nietz, John A. Old Textbooks: Spelling, Grammar, Reading, Arithmetic, Geography, American History, Civil Government, Physiology, Penmanship, Art Music - As Taught in the Common Schools From Colonial Days to 1900. Pittsburgh: University of Pittsburgh Press, 1961.

O'Brien, Richard. The Story of Toys from the Puritans to the Present. New York: Abbeville Press, 1990.

Oetterman, Stephan. The Panorama: History of a Mass Medium. Translated by Deborah Lucas Schneider. New York: Zone Books, 1997.

Oleksijczuk, Denise Blake. The First Panoramas: Visions of British Imperialism. Minneapolis and London: University of Minnesota Press, 2011.

Onuf, Nicholas and Peter Onuf. Nations, Markets, and War: Modern History and the American Civil War. Charlottesville and London: University of Virginia Press, 2006.

Opie, Iona and Robert and Brian Alderson. The Treasures of Childhood: Books, Toys, and Games from the Opie Collection. New York: Arcade Publishing, 1989.

Osterweis, Rollin G. The Myth of the Lost Cause 1865-1900. Hamden, CT: Archon Books, 1973.

Palumbo, Anne Cannon. “Averting 'Present Commotions': History as Politics in Penn's Treaty.” American Art 9 (fall 1995): 29-55.

“Penn Treaty Elm,” Haverford College Arboretum, accessed February 2020, https://www.haverford.edu/arboretum/arboretum-highlights/penn-treaty-elm

Peters, Harry T. Currier and Ives: Printmakers to the American People. Garden City, New York: Doubleday, Doran and Co., Inc., 1942.

Peterson, Harold L. Americans at Home From the Colonists to the Late Victorians. New York: Charles Scribner's Sons, 1971. 
Peterson, Jennifer Lynn. "The Historiscope and the Milton Bradley Company: Art and Commerce in Nineteenth-Century Aesthetic Education." Getty Research Journal 6 (January 2014): 175-184.

Pierson, Ruth Roach. "Nations: Gendered, Racialized, Crossed With Empire." In Gendered Nation: Nationalisms and Gender Order in the Long Nineteenth Century." Oxford and New York: Berg, 2000.

Pohl, Frances K. Framing America: A Social History of American Art. New York: Thames and Hudson, 2002.

Pratt, John Lowell Pratt, ed., intro by A.K. Baragwanath, Curator of Prints, The Museum of the City of New York. Currier and Ives: Chronicles of America. Maplewood, NJ: Hammond Inc., 1968. Color plates reproduced from the original hand colored stone prints by N. Currier, and Currier and Ives.

Prown, Jules David. Art As Evidence: Writings on Art and Material Culture. New Haven and London: Yale University Press, 2001.

Pyne, Kathleen. Art and the Higher Life: Painting and Evolutionary Thought in Late $19^{\text {th }}$ Century America. Austin: University of Texas Press, 1996.

Rabb, Theodore K. and Robert I. Rotberg, eds. The Family in History: Interdisciplinary Essays. New York and London: Harper \& Row, 1971.

Rath, Robert. "Board Games Were Indoctrination Tools for Christ, Then Capitalism: the very weird tale of how American board games used to teach you how to get to heaven, and later, how to make bank. November 30, 2017. Accessed 2/24/2020. Vice.com/en_us/article/vb38gj/mansion-of-happiness-boardgames-history

Rathbone, Perry T., ed. Mississippi Panorama: the life and landscape of the Father of Waters and its great tributary, the Missouri. St. Louis: City Museum of St. Louis, 1950.

Rawls, Walton. The Great Book of Currier and Ives' America. New York: Abbeville Press, 1979.

Reinhardt, Leslie. "British and Indian Identities in a Picture by Benjamin West," Eighteenth-Century Studies 31, no. 3 (1998): 283-305.

Rigal, Laura. “Framing the Fabric: A Luddite Reading of Penn's Treaty with the Indian," American Literary History 12 (fall 2000): 557-584.

Rourke, Constance Mayfield. Trumpets of Jubilee: Henry Ward Beecher, Harriet Beecher Stowe, Lyman Beecher, Howard Greeley, P.T. Barnum. New York: Harcourt, Brace and Co., 1927. 
Rourke, Constance Mayfield. American Humor: A Study of the National Character. New York: Harcourt, Brace and Co., 1931.

Rourke, Constance, ed. The Roots of American Culture and Other Essays. New York: Harcourt, Brace and Co., 1942.

Russell, Jeffrey Burton. Inventing the Flat Earth: Columbus and Modern Historians. New York: Praeger, 1991.

Ryan, Mary P. Cradle of the Middle Class: The Family in Oneida County, New York, 1790-1865. Cambridge, London, New York: Cambridge University Press, 1981.

Savage, Kirk, ed. The Civil War in Art and Memory. New Haven and London: Yale University Press, 2016.

Savage, Kirk. Standing Soldiers, Kneeling Slaves: Race, War, and Monument in Nineteenth-Century America. Princeton, N.J.: Princeton University Press, 1997.

Schivelbusch, Wolfgang. The Railway Journey: The Industrialization of Time and Space in the Nineteenth Century. Translated by Anselm Holo. Berkeley: University of California Press, 1986.

Schulz, Emily L. "The Historiscope: A Nineteenth-Century American History Toy," Cincinnati Fourteen: Journal of the Society of the Cincinnati 43, no.2 (2007): 70-71.

Schwain, Kristin. Religion and American Art in the Gilded Age. Ithaca and London: Cornell University Press, 2008.

Scott, Joan Wallach. "Some More Reflections on Gender and Politics." In Gender and the Politics of History, revised edition, 199-222. New York: Columbia University Press, 1999.

Seale, William. The Tasteful Interlude: American Interiors Through the Camera's Eye, 1860-1917. New York: Praeger Publishers, 1975.

Shea, James J. as told to Charles Mercer. It's All in the Game. New York: G.P. Putnam's Sons, 1960.

Shea, Jr., James J. “The Milton Bradley Story.” Newcomen Society in North America, Addresses 636-654 (November 2, 1972): 5-24.

Sheriff, Mary, ed. Cultural Contact and the Making of European Art Since the Age of Exploration. Chapel Hill, North Carolina: The University of North Carolina Press, 2010. 
Sheriff, Mary. "The Cradle is Empty: Elisabeth Vigée-Lebrun, Marie-Antoinette, and the Problem of Intention." In Women, Art and the Politics of Identity in EighteenthCentury Europe, edited by Melissa Hyde and Jennifer Milam. Burlington, VT: Ashgate, 2003.

Simpson, Marc. Winslow Homer: Paintings of the Civil War [exh. cat.]. San Francisco: Bedford Arts, Publishers, 1988.

Sklar, Kathryn Kish. Catharine Beecher: A Study in American Domesticity. New Haven and London: Yale University Press, 1973.

Smith, David L. Horace Bushnell: Selected Writings on Language, Religion, and American Culture. Chico, California: Scholars Press, 1984.

Snyder, Joel and Doug Munson. The Documentary Photograph as a Work of Art: American Photographs, 1860-1876. Prepared in conjunction with an exhibition of same name October 13 - December 12, 1976. Chicago: University of Chicago, The David and Alfred Smart Gallery, 1976.

Stafford, Barbara Maria and Frances Terpak. Device of Wonder: From the World in a Box to Images on a Screen. Los Angeles, CA.: Getty Research Institute, 2001.

Sullivan, George. In the Wake of Battle: The Civil War Images of Mathew Brady. Munich, Berlin, London, New York: Prestel, 2004.

Sutton-Smith, B. and B. G. Rosenberg. "Sixty Years of Historical Change in the Game Preferences of American Children." The Journal of American Folklore 74, no. 291 (January - March 1961): 17-46.

Thompson, William Fletcher Jr. "Illustrating the Civil War." The Wisconsin Magazine of History 45.1 (Autumn 1961): 10-20.

Thwing, Leroy. Flickering Flames: A History of Domestic Lighting through the Ages. Rutland, Vermont: Charles E. Tuttle Company, 1966.

Tilton, Robert S. Pocahontas: The Evolution of an American Narrative. Cambridge: Cambridge University Press, 1994.

Truettner, William H. "Storming the Teocalli - Again: Or, Further Thoughts on Reading History Paintings." American Art 9, no. 3 (Autumn 1995): 56-95.

Truettner, William H. The West as America: Reinterpreting Images of the Frontier, 1820-1920 [exh. cat.]. Washington and London: Smithsonian Institution Press, 1991.

Tyack, David B., ed. Turning Points in American Educational History. New York: John Wiley and Sons, 1967. 
Tyack, David. Seeking Common Ground: Public Schools in a Diverse Society. Cambridge and London: Harvard University Press, 2003.

Urban, Wayne J. and Jennings L. Wagoner, Jr. American Education: A History. New York: McGraw-Hill Companies, Inc., 1996.

Uricchio, William. "A 'Proper Point of View': The Panorama and some of Its Early Media Iterations," Early Popular Visual Culture 9, no. 3 (2012): 225-38.

Vinovskis, Maris A. "Family and Schooling in Colonial and Nineteenth-Century America." Journal of Family History 12.1-3 (1987): 19-37.

Volo, James M. and Dorothy Denneen Volo. Family Life in 19th-Century America. Westport, Connecticut and London: Greenwood Press, 2007.

Westerhoff, John H. III. McGuffey and His Readers: Piety, Morality and Education in Nineteenth-Century America. Nashville: Abington, 1978.

White, John. Reconstruction after the Civil War. London: Longman Group Ltd., 1977.

Whitehall, Bruce. "Games Old and New - the history, the products, the companies and the people involved with board games, skill and action games and parlor games." The Big Game Hunter. Accessed February 24, 2020. thebiggamehunter.com/games-one-by-one/checkered-game-of-life/

Winkler, Gail Caskey and Roger W. Moss. Victorian Interior Decoration: American Interiors 1830-1900. New York: Henry Holt and Company, 1986.

Woodhead, Henry, ed. Echoes of Glory: Arms and Equipment of the Confederacy. Alexandria, VA: Time-Life Books, 1998.

Woodhead, Henry, ed. Echoes of Glory: Arms and Equipment of the Union. Alexandria, VA: Time-Life Books, 1998.

Wright, Gwendolyn. Building the Dream: A Social History of Housing in America. New York: Pantheon Books, 1981.

Yonan, Michael. "Toward a Fusion of Art History and Material Culture Studies," West $86^{\text {th }} 18$ no. 2 (Fall-Winter 2011): 96-112. 
Margaret Fairgrieve Milanick grew-up in Mystic, Connecticut and attended Robert E. Fitch Senior High School where she graduated with honors in 1971. She attended the University of Connecticut in Storrs where she earned a Bachelor of Arts degree Cum Laude in Biology and Pathobiology in 1977. She worked at Yale University Medical School in the Department of Human Genetics as a Research Specialist, while earning a Master of Science degree in Molecular Biology at Southern Connecticut State University with a thesis entitled "Isolation and Characterization of A Glycine Transport Defective Mutant in an Established Mammalian Cell Line, CHO(PEOT/1)." Although she studied Molecular Biology and worked as a research scientist in the 1970s and '80s, she pursued her interest in Art History when she moved to Columbia, Missouri with her husband in 1986. In 1991, she graduated from the Docent-training program at the University of Missouri Museum of Art and Archaeology, and continues to work as a Docent at the museum. In 2009, she graduated from the University of Missouri-Columbia Department of Art History and Archaeology with a Master of Arts degree, writing a thesis entitled "The Chinese Scholar's Garden in France: Moulin Joli in Claude-Henri Watelet's Essai Sur Les Jardins." Her research interests include seventeenth and eighteenth-century landscape design, eighteenth-century French material and visual culture, and nineteenth and twentieth-century American material and visual culture. Milanick has presented her research at many different venues on these topics, including at the Graduate Student Seminar at the Art Institute in Chicago, the National Basketry 
Organization Biennial Conference in Tacoma, Washington, the Museum of Art and Archaeology Museum Lecture Series, Friends of the Mizzou Botanic Garden Annual Meeting, and Daniel Boone Regional Library. She has published two papers in MVSE: "An Eighteenth-Century Snuffbox as an Object of Social Status" in 2009 and "Missouri Heart of the Nation: Art, Commerce and Civic Pride" in 2014, as well as the essay "Fashioning Nantucket Mink: From Lightship Basket to Friendship Purse" in the exhibition catalog Rooted, Revised and Reinvented: Basketry in America (2017). The third chapter of her dissertation will be published under the title "Big Ideas in a Little Box: Nation-Building in Milton Bradley \& Company's Myriopticon” in an anthology of essays edited by Drs. Caroline Janney and James Marten. 